University of San Diego

Digital USD

Fall 1-1-2016

\title{
Geochemical Investigation of Anomalous Arsenic Enrichment in the Santiago Peak Volcanics of Southern California
}

Elizabeth C. Johnston

University of San Diego

Follow this and additional works at: https://digital.sandiego.edu/theses

Part of the Geochemistry Commons

\section{Digital USD Citation}

Johnston, Elizabeth C., "Geochemical Investigation of Anomalous Arsenic Enrichment in the Santiago Peak Volcanics of Southern California" (2016). Theses. 13.

https://digital.sandiego.edu/theses/13

This Thesis: Open Access is brought to you for free and open access by the Theses and Dissertations at Digital USD. It has been accepted for inclusion in Theses by an authorized administrator of Digital USD. For more information, please contact digital@sandiego.edu. 


\title{
UNIVERSITY OF SAN DIEGO
}

\author{
San Diego
}

Geochemical Investigation of Anomalous Arsenic Enrichment in the Santiago Peak Volcanics of Southern California

\begin{abstract}
A thesis submitted in partial satisfaction of the
requirements for the degree of
\end{abstract}

Master of Science in Marine Science

by

Elizabeth C. Johnston

\author{
Thesis Committee \\ Bethany O'Shea, Ph.D., Chair \\ Meagen Pollock, Ph.D. \\ Eric M. Cathcart, P.G.
}


The thesis of Elizabeth Johnston is approved by:

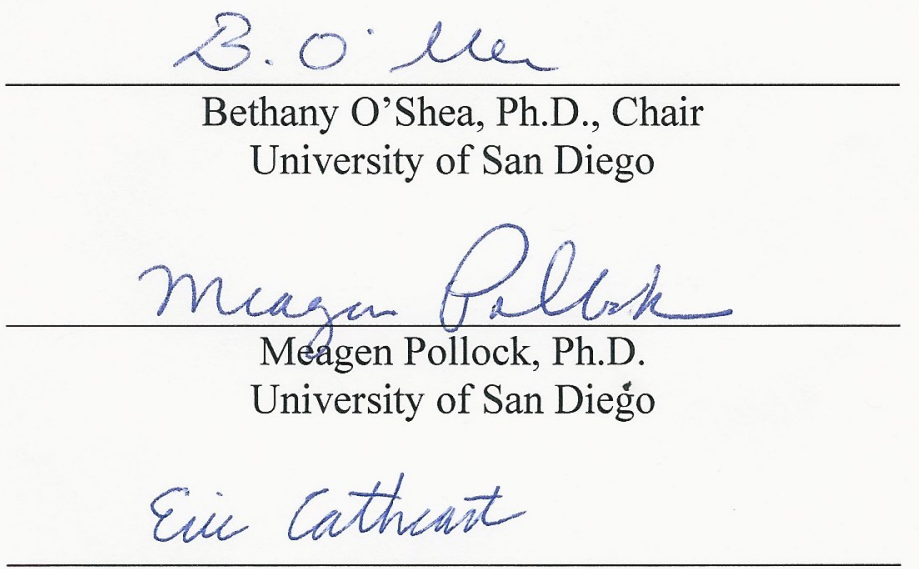

Eric Cathcart, P.G.

University of San Diego

University of San Diego

San Diego

2016 
Copyright 2016 Elizabeth Johnston 


\section{ACKNOWLEDGMENTS}

I would like to first acknowledge the sources of funding that made this project possible: 1) the San Diego Association of Environmental Professionals Student Scholarship, and 2) the Stephen E. Sullivan Memorial Scholarship. I could not have conducted this study without the generous support of these scholarships, as they were primarily used to cover research costs. I would also like to thank those who kindly allowed me to use their scientific instruments and provided training: Dr. Meagen Pollock (College of Wooster), Joan Kimbrough, Heather Webb (San Diego State University), Dr. Sarah Gray, Dr. Lisa Baird, and Dr. Steven Morrison (University of San Diego).

I would like to thank Amineh AlBashairesh for her help in the lab, and Mariah Banks, Joseph Chiappe, Ayah Karadesh, and Colin Phillips assistance in the field. Special thanks to my favorite field assistant, Stephen Campbell, who I could always count on for a last-minute trip to Black Mountain. Finally, I would like to thank my committee members for sharing their love of rocks, and for their continuous encouragement and support. 


\section{TABLE OF CONTENTS}

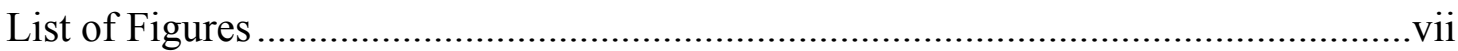

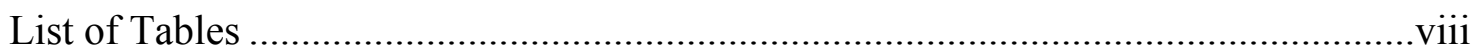

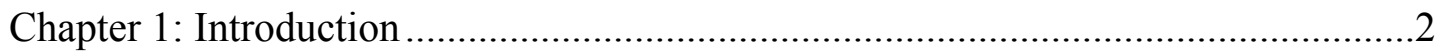

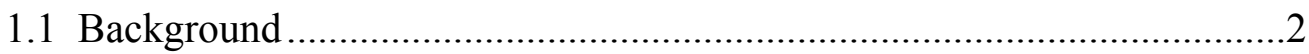

1.2 Arsenic in the natural environment: literature review .............................. 3

1.2.1 Geogenic arsenic enrichment..................................................

1.2.2 Arsenic host minerals.............................................................

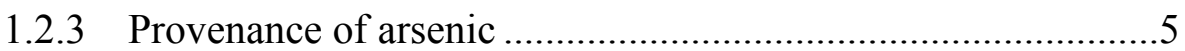

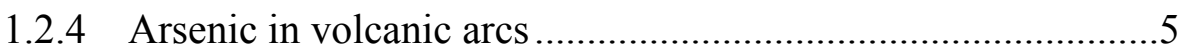

1.2.5 The Santiago Peak Volcanics....................................................

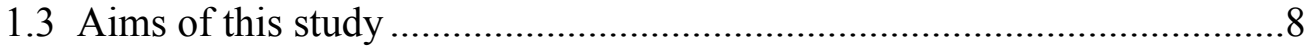

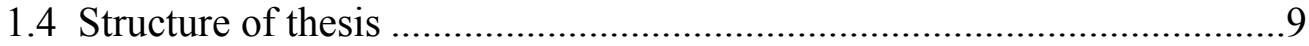

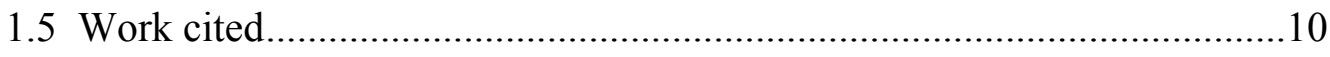

Chapter 2: Arsenic enrichment in the Santiago Peak Volcanics of Southern California: implications for As geochemical cycling in volcanic arc systems ...............................12

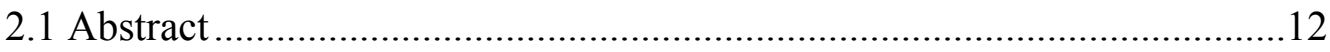

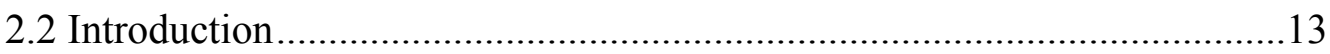

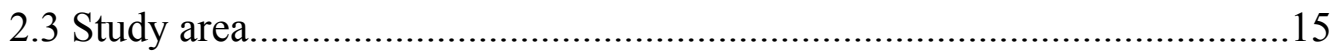

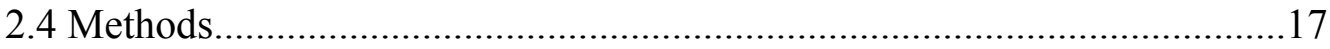

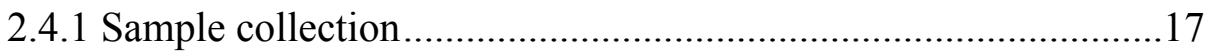

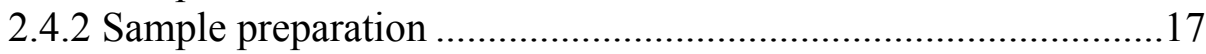

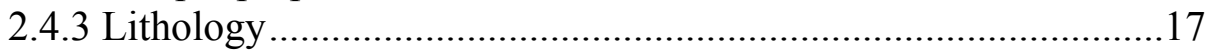

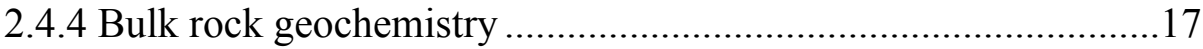

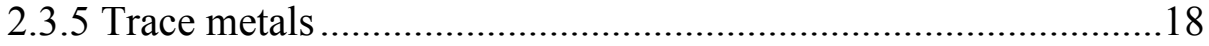

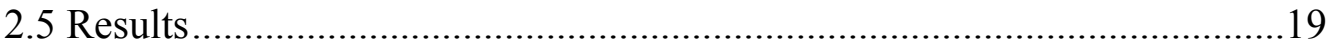

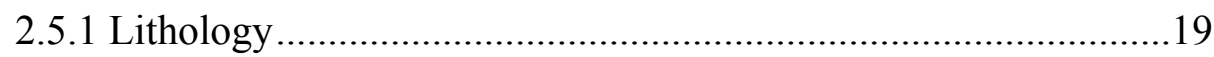

2.5.2 Bulk geochemistry ...............................................................21

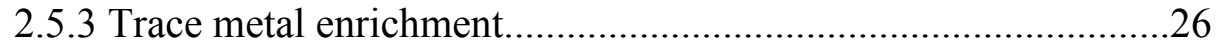

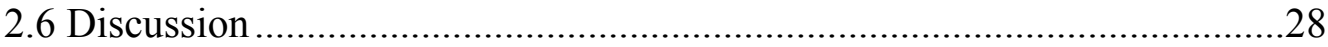

2.6.1 Volcanic arc provenance of rocks outcropping at Black Mountain. 28

2.6.2 Arsenic enrichment in relation to volcanic arc processes ............29

2.6.2.1 Partial melt evolution ................................................29

2.6.2.2 Arsenic mobility in subduction zone fluids..................32

2.6.3 Model for arsenic occurrence in Black Mountain SPV .................34

2.6.4 Potential for groundwater As enrichment ......................................36

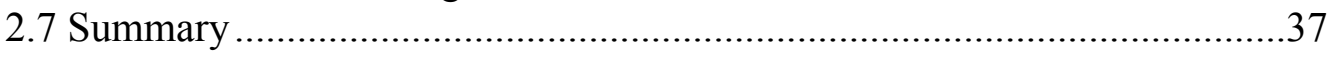

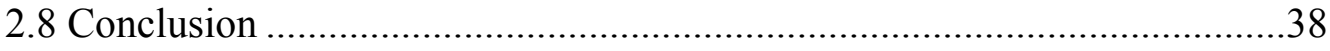

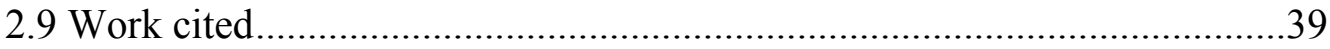

Chapter 3: Arsenic Mineral Associations in the Black Mountain SPV Ore Deposit....43 


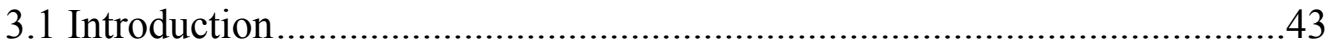

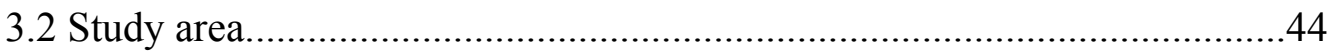

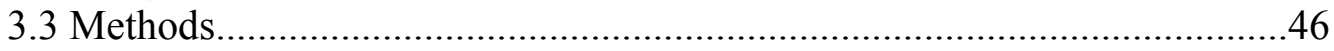

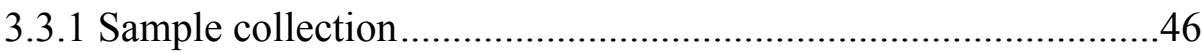

3.3.2 Bulk rock preparation .............................................................46

3.3.3 Sub-sample preparation ...........................................................46

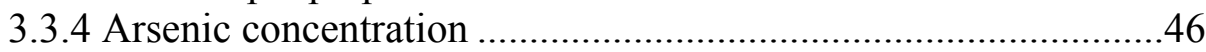

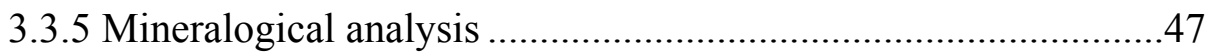

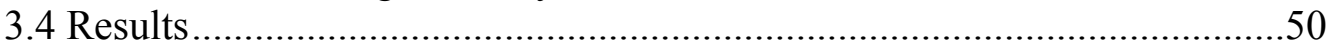

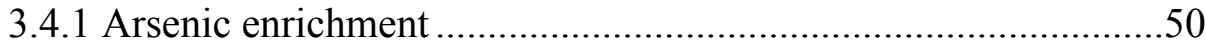

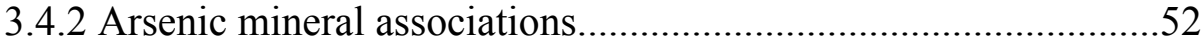

3.4.2.1 Field observations......................................................52

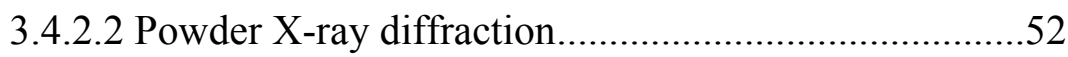

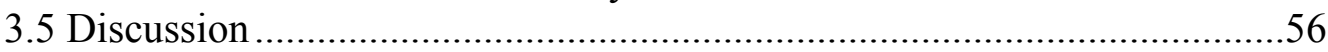

3.5.1 Arsenic enrichment in Black Mountain SPV ...............................56

3.5.2 Arsenic in fresh versus weathered rock .....................................56

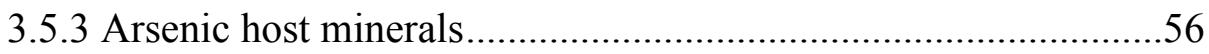

3.5.4 Arsenopyrite weathering .........................................................57

3.5.5 Sulfate replacement by arsenate .................................................58

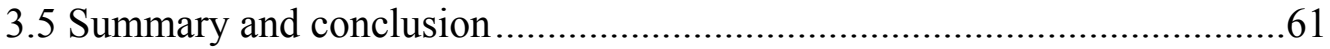

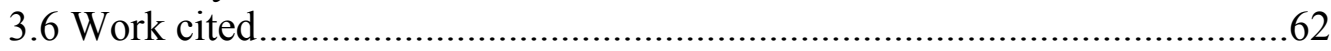

Chapter 4: Summary and conclusion .....................................................................63

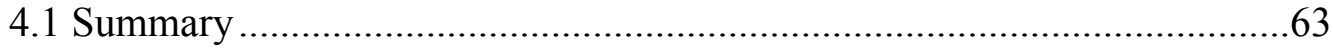

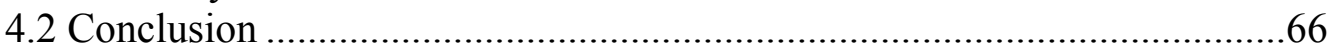

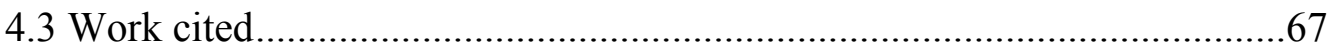

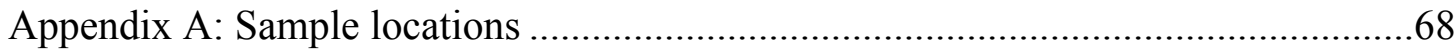

Appendix B: Trace metals in rhyolites and dacites $(\mathrm{n}=20) \ldots \ldots \ldots \ldots \ldots \ldots \ldots \ldots \ldots \ldots \ldots \ldots \ldots \ldots . . .70$

Appendix C: Trace metals in all samples and subsamples $(\mathrm{n}=168) \ldots \ldots \ldots \ldots \ldots \ldots \ldots \ldots \ldots . . .71$

Appendix D: Arsenic correlation with lead, antimony, copper, and zinc $(\mathrm{n}=168) \ldots . .76$

Appendix E: Trace metal content in fresh versus weathered subsamples of Black

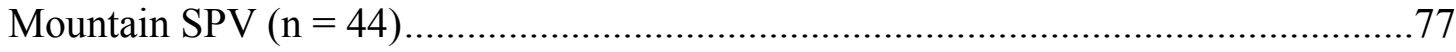

Appendix F: XRD results for all samples and subsamples $(\mathrm{n}=168) \ldots \ldots \ldots \ldots \ldots \ldots \ldots \ldots \ldots . . .78$

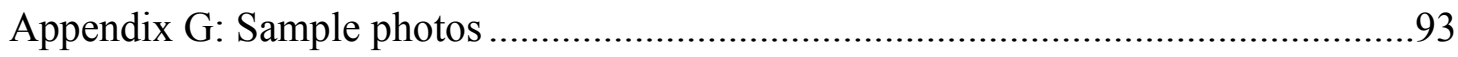

Appendix H: Analytical laboratory (EMA) results...................................................128

Appendix I: Scanning electron microscope …………….......................................132 


\section{LIST OF FIGURES}

Figure 2.1. 1:30,000 geologic map of Black Mountain Open Space Park....16

Figure 2.2. Photomicrographs taken in cross-polarizing light ....................20

Figure 2.3. Jensen Cation and TAS diagrams ........................................22

Figure 2.4. Bivariate plots showing concentration of $\mathrm{SiO}_{2}$ relative to $\mathrm{K}_{2} \mathrm{O}$,

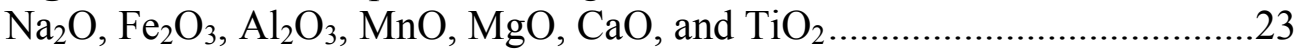

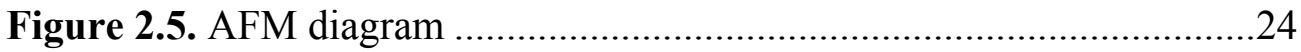

Figure 2.6. Bivariate plots comparing As content to $\mathrm{K}_{2} \mathrm{O}, \mathrm{Na}_{2} \mathrm{O}, \mathrm{Fe}_{2} \mathrm{O}_{3}$,

$\mathrm{Al}_{2} \mathrm{O}_{3}, \mathrm{MnO}, \mathrm{MgO}, \mathrm{CaO}, \mathrm{TiO}_{2}$, and $\mathrm{SiO}_{2}$

Figure 2.7. Model explaining provenance of As in Black Mountain SPV ...35

Figure 3.1. Location of Black Mountain Open Space Park ........................45

Figure 3.2. Distribution of arsenic in rocks and soil ...............................49

Figure 3.3. Photographs of arsenic host minerals ...................................53

Figure 3.4. XRD spectra for arsenic host minerals ..................................54

Figure 3.5. Arsenic in fresh versus weathered rocks ................................54

Figure 3.6. Schematic of arsenopyrite weathering..................................60 


\section{LIST OF TABLES}

Table 2.1. QA/QC for Innov-X-5000 ......................................................18

Table 2.2. Major element composition of bulk rock samples ....................25

Table 2.3. Summary of trace element enrichment in bulk rocks..................27

Table 3.1. QA/QC for samples with anomalous arsenic concentrations.......48

Table 3.2. Summary of trace element enrichment in all samples ................51

Table 3.3. Trace metal content of samples containing goethite ...................55 


\section{CHAPTER 1: Introduction}

\subsection{Background}

Black Mountain Open Space Park is located in the Rancho Peñasquitos neighborhood of northern San Diego, and is owned and managed by the City of San Diego. Though artisanal arsenic (As) mining occurred on-site during the 1920's (Stewart 1963), the park remains a popular destination for local hikers and bikers, and is surrounded by a relatively dense suburban population. Our initial investigation of soils and rocks throughout the park by field portable Xray fluorescence (FP-XRF, Haffert and Craw 2009) revealed As concentrations up to 400,000 ppm. Such concentrations are nearly 100,000 times greater than average for the upper-crust (4.8 ppm, Rudnick and Gao 2003) and, thus, indicate the need to investigate As enrichment throughout the park and the potential for As to be mobilized off-site. This thesis investigates As distribution among rocks cropping out at Black Mountain Open Space Park. 


\subsection{Arsenic in the natural environment: literature review}

Arsenic (As) occurs naturally as the $20^{\text {th }}$ most abundant trace element in the Earth's crust and is widely distributed in the environment. Arsenic exists in organic and inorganic forms and in several valence states (e.g. $-3,0,+3,+5$ ) that reflect the redox conditions of its geochemical environment. Toxicologists are primarily concerned with $\mathrm{As}^{3+}$ and $\mathrm{As}^{5+}$, since both are toxic and present in natural waters (Duker et al. 2005).

Of the various sources of As in the environment, ingestion of As-enriched groundwater poses the greatest threat to human health. However, inhalation of airborne As is an additional exposure pathway, along with consuming food grown in As-rich soil (Smedley and Kinniburgh 2001). Long-term exposure can cause chronic As poisoning, impairment of cognitive development, neurotoxicity, diabetes, cardiovascular disease, and bladder, lung, and kidney cancer, as demonstrated in India and Bangladesh, where an estimated 36 to 75 million people in the Bengal Delta were at risk from drinking As-contaminated groundwater at the end of the $20^{\text {th }}$ century (Mukherjee and Bhattacharya 2001, Nordstrom 2002). Such findings have prompted further investigation of the factors controlling As distribution in the natural environment.

\subsubsection{Geogenic arsenic enrichment}

In the natural environment, As can be anthropogenic or geogenic. Geogenic As is a product of natural geological processes and is, therefore, not a result of human activities. Geogenic As is present in both terrestrial and marine environments, and its concentration varies greatly as a result of mobilization by natural and/or anthropogenic processes (Smedley and Kinniburgh 2001). The average As concentration in the upper continental crust is $4.8 \mathrm{mg} / \mathrm{kg}$ (Rudnick and Gao 2003), and average enrichment differs among rock types. In igneous rocks, the average As concentration is approximately $1.5 \mathrm{mg} / \mathrm{kg}$. In metamorphic rocks, As is typically 
less than $5 \mathrm{mg} / \mathrm{kg}$ (Smedley and Kinniburgh 2001), while As in sedimentary rocks ranges from 5 to $10 \mathrm{mg} / \mathrm{kg}$ (Webster 1999). Weathering, erosion, and sedimentation, in addition to As contribution from source magmas, lavas, and metamorphic fluids, are important natural processes in controlling As enrichment in the upper crust (Henke 2009). Therefore, As enrichment in individual rock units may deviate significantly from the averages presented above.

\subsubsection{Arsenic host minerals}

In As-rich rocks, As most commonly forms sulfide minerals, as well as associations with oxides and, less commonly, phosphates (Drahota and Filippi 2009, Majzlan et al. 2014). Arsenicbearing sulfide minerals are especially common in hydrothermal deposits, causing As to be associated with metal ore minerals and their alteration products (Henke 2009). With exposure to the atmosphere and surface or groundwater, these primary minerals undergo alteration reactions to form secondary minerals, like As oxides or more complicated phases with As, oxygen, and metals (e.g. Fe, Mn, Ni, Drahota and Filippi 2009).

Modern water-rock interactions often cause As to be leached from primary and/or secondary host minerals, making As one of the most problematic trace metals in the environment (Smedley and Kinniburgh 2001). Human activities can greatly influence the stability of As host minerals by altering redox conditions. For example, mining As-bearing ore deposits exposes greater surface area of As-enriched minerals to air and aerated water, leading to increased As leaching and, thus, greater mobilization off-site (Henke 2009). Consequently, concentrations of natural As in drinking water above standards $(10 \mu \mathrm{g} / \mathrm{L})$ are not uncommon. Countries/regions with groundwater elevated in As include: Bangladesh ( $<1$ to 2,500 $\mu \mathrm{g} / \mathrm{L})$, West Bengal, India

( $<10$ to 3,200 $\mu \mathrm{g} / \mathrm{L}$ ), Thailand ( 1 to $>5,000 \mu \mathrm{g} / \mathrm{L}$ ), Argentina ( $<1$ to $9,900 \mu \mathrm{g} / \mathrm{L}$ ), Chile (100 to 
$1,000 \mu \mathrm{g} / \mathrm{L})$, and the southwestern Unites States $(0.38-1000 \mu \mathrm{g} / \mathrm{L})$ (Smedley and Kinniburgh 2001, Nordstrom 2002).

\subsubsection{Provenance of arsenic}

Recent documentation of the acute and chronic effects of exposure to As in drinking water has emphasized the importance of better-understanding the sources, pathways, and controls on high As in various environmental systems (Smedley and Kinniburgh 2001). Source materials currently considered to be significant contributors of As in global drinking water supplies include: organic-rich black shales, Holocene alluvial sediments with slow flushing rates, mineralized and mined areas (most often gold deposits), volcanogenic sources, and thermal springs (Nordstrom 2002, Mukherjee et al. 2014). However, because aquifers in sediments and sedimentary rocks typically yield more water for drinking supplies (Smedley and Kinniburgh 2001), attention to other source materials, like volcanic host rocks, remains in deficit.

\subsubsection{Arsenic in volcanic arcs}

Mukherjee et al. (2014) suggest that the global distribution of geogenic As in groundwater is largely controlled by As mobilization in subduction zone fluids, since As enrichment tends to occur in orogenic belts, like the Himalayan, Andean, Western Cordilleran, and Appalachian mountain chains (Mukherjee et al. 2014). Their hypothesis is largely based on the work of Hattori and Guillot (2003), who provide a mechanism for As enrichment in such environments.

Specifically, Hattori and Guillot (2003) propose that the dehydration of subduction zone serpentinites accounts for the observed enrichment of soluble elements in volcanic arc magmas, which are later exhumed to form As-rich volcanic rocks that are eventually incorporated into mountain chains. During subduction, hydrous minerals in subducting slabs and overlying sediments release water and soluble elements (e.g. $\mathrm{As}, \mathrm{Pb}, \mathrm{Sb}$ ) because of increased pressure and 
temperature. After release, such elements and water migrate upward, hydrating the mantle peridotite and forming a serpentinite layer along the plate boundary. The dissolved elements become concentrated as water is consumed by dehydration and eventually become fixed in the serpentinites. Because serpentinites act as a sink for water, serpentinite layers prevent the mantle wedge from partially melting. Thus, the serpentinite layer will continue to subduct with the plate until depths exceed $\sim 100 \mathrm{~km}$. Temperatures of about $650^{\circ} \mathrm{C}$ completely dehydrate the serpentinite to ecologite, releasing hydrothermal fluid and fluid-soluble elements, which hydrate and enrich the overlying mantle wedge and cause partial melting. When the angle of subduction is steep, fluids released from serpentinite dehydration may be focused on a relatively narrow zone more directly beneath the volcanic front, resulting in greater enrichments of fluid soluble elements (Noll et al. 1996). Partial melts eventually rise via buoyancy and hydrostatic pressure and are exhumed by volcanic arcs (Hattori and Guillot 2003). Due to its high solubility, Hattori and Guillot (2003) suggest that As is among the first elements released from the serpentinites and incorporated into the partial melt during serpentinite dehydration. (Breuer and Pichler 2013, Henke 2009, Ballantyne and Moore 1988). Consequently, As is often concentrated in rocks associated with ancient volcanic fronts (Hattori and Guillot 2003). However, Mukherjee et al. (2014) recommends targeted field studies to enhance understanding of this As cycling in these volcanic settings.

\subsubsection{The Santiago Peak Volcanics}

The Santiago Peak Volcanics (SPV) of Southern California and Northern Baja California, Mexico are remnants and a subaerial volcanic arc, located in the southern portion of the Western Cordilleran orogenic belt. Though its petrogenesis has been disputed (Fife et al. 1996), Herzig and Kimbrough (2014) suggest that the SPV evolved along the western coast of North America 
during the Cretaceous and, thus, belong to the magmatic plumbing system of the western zone of the Peninsular Ranges Batholith (PRB). In the 1920's, the SPV outcropping at Black Mountain Open Space Park was mined for white As. Mining efforts were small-scale and short-lived, with just 700 pounds of material containing 31.4\% As shipped from the property (Stewart 1963). 


\subsection{Aims of this study}

Our findings of anomalous As enrichment (>1,000 ppm) in volcanic rocks exposed at Black Mountain Open Space Park provide an excellent opportunity to investigate As cycling in volcanic arcs, while examining the extent of As enrichment throughout the park and the potential for As to be mobilized from primary and/or secondary host minerals. Thus, this thesis poses the following research questions:

1. What is the geology of rocks cropping out at Black Mountain Open Space Park, and over what spatial scale does rock type vary?

2. What is the distribution of As among SPV rock types, and how can we use this knowledge to propose a model for As cycling in the ancient volcanic arc system?

3. What are the primary and secondary As host minerals in Black Mountain SPV, and how does knowledge of host minerals inform future research investigating As mobility? 


\subsection{Thesis structure}

Research Questions 1 and 2 are presented in Chapter 2, while Chapter 3 addresses Research Question 3. Chapter 2 is written as a manuscript for publication, while Chapter 3 intends to inform future research at Black Mountain Open Space Park. Supplementary data, figures, and analyses are collated in the appendices of this thesis. 


\subsection{Work Cited}

Ballantyne, M., J. Moore, 1988. Arsenic geochemistry in geothermal systems. Geochim. Cosmochim. Acta 52 (2): 475-483.

Breuer, C., T. Pichler, 2013. Arsenic in marine hydrothermal fluids. Chem. Geol. 348, 2-14.

Drahota, P., M. Filippi, 2009. Secondary arsenic minerals in the environment: a review. Environ. Int. 35(8): 1243-1255.

Duker, A. A., E.J. Carranza, \& M. Hale, 2005. Arsenic geochemistry and health. Environ. Int. 31(5): 631-641.

Fife, D.L., J.A. Minch, and P.J. Crampton, 1967. Late Jurassic age of the Santiago Peak Volcanics, California: Geol. Society of America Bulletin 78: 299-304.

Haffert, L., D. Craw, 2009. Field quantification and characterization of extreme arsenic concentrations at a historic mine processing site, Waiuta, New Zealand. New Zealand Journal of Geology and Geophysics 52: 261-271.

Hattori, K.H., S. Guillot, 2003. Volcanic fronts form as a consequence of serpentinite on the forearc mantle wedge. Geol. 31(6): 525-528.

Henke, K., 2009. Arsenic: environmental chemistry, health threats and waste treatment. John Wiley \& Sons, pp. $69-235$.

Herzig, C.T., D.L. Kimbrough, 2014. Santiago peak volcanics: Early Cretaceous arc volcanism of the western Peninsular Ranges batholith, southern California. GSA Memoir 211, 345363.

Majzlan, J., P. Drahota, M. Filippi, 2014. Parageneses and crystal chemistry of arsenic minerals. Reviews in Mineralogy and Geochemistry 79(1): 17-184.

Mukherjee, A., P. Bhattacharya, 2001. Arsenic in groundwater in the Bengal Delta Plain: slow poisoning in Bangladesh. Environ. Rev. 9(3): 189-220.

Mukherjee, A., S. Verma, S. Gupta, K.R. Henke, P. Bhattacharya, 2014. Influence of tectonics, sedimentation and aqueous flow cycles on the origin of global groundwater arsenic: Paradigms from three continents. J. of Hydrol. 518, 284-299.

Noll, P.D., H.E. Newsom, W.P. Leeman, J.G. Ryan, 1996. The role of hydrothermal fluids in the production of subduction zone magmas: Evidence from siderophile and chalcophile trace elements. Geochim. Cosmochim. Acta 60(4): 587 - 611.

Nordstrom, K., 2002. Worldwide occurrence of arsenic in groundwater. Science 296 (5576): $2143-2145$. 
Rudnick, R.L., S. Gao., 2003. 3.01- Composition of the Continental Crust Holland. In: H. D., K.K. Turekian (Eds.) Treatise on Geochemistry. Oxford, Pergamon, pp. 1-64.

Shanks, W.C., R. Koski, 2012. Introduction. In: Volcanogenic massive sulfide occurrence model: U.S. Geological Survey Scientific Investigations Report 2010-5070 -C, pp. 5 -8.

Smedley, P.L., D.G. Kinniburgh, 2001. A review of the source, behaviour and distribution of arsenic in natural waters. Appl. Geochem. 17: 517-668.

Stewart, R.M. 1963. Mines and mineral resources of San Diego County, California. California Division of Mines and Geology County Report 3, pp. 49-50.

Webster, J.G., 1999. Arsenic. In: Marshall, C.P., Fairbridge, R.W. (Eds.), Encyclopeadia of Geochemistry. Chapman Hall, London, pp. 21-22. 
CHAPTER 2: Arsenic enrichment in the Santiago Peak Volcanics of Southern California: implications for geogenic arsenic distribution in ancient and modern volcanic arc systems

\subsection{Abstract}

Arsenic (As) is enriched in the Santiago Peak Volcanics (SPV) that crop out at Black Mountain Open Space Park in San Diego, CA. Thus, the Black Mountain SPV present an excellent opportunity to investigate As enrichment in ancient volcanic arc systems as a result of deep earth subduction zone processes. Through targeted field study of this unit, we aim to (1) confirm the volcanic arc provenance of rocks cropping out at Black Mountain, (2) investigate As enrichment in relation to volcanic arc processes, and (3) propose a model for As occurrence in the SPV. Our findings indicate Black Mountain SPV evolved from the same magma system as Northern Santa Ana Mountain SPV during the Cretaceous, and that As content varied between the two dominant SPV rock types, with rhyolites containing more As $(\mathrm{n}=10$, mean $=586 \pm 10$ ppm As) than dacites $(\mathrm{n}=10$, mean $=14 \pm 9 \mathrm{ppm}$ As). Our proposed model for As enrichment in SPV suggests that As is among the first elements released during serpentinite dehydration (along with $\mathrm{Pb}$ ), while less soluble elements (e.g. $\mathrm{Cu}$ ) are released during later stages of subduction. Once $\mathrm{As}$ and $\mathrm{Pb}$ are released from serpentinites and incorporated into partial melts, we hypothesize that such elements behave like typical incompatible elements and remain dissolved in melts until they are eventually exhumed in rhyolitic lavas. Since As may dissolve out of volcanic host rocks in groundwater aquifers, this enhanced understanding of As distribution among ancient volcanic arc rocks may aid in identifying alternative drinking water sources in regions with known groundwater As enrichment. 


\subsection{Introduction}

Modern volcanic arc systems provide conditions where fluid soluble elements like arsenic (As) can be enriched in subduction zone magmas (Ballantyne and Moore 1988, Hattori and Guillot 2003, Breuer and Pichler 2013). Thus, ancient volcanic arcs are plausible host provinces of As-enriched volcanic rocks (Mukherjee et al. 2014). However, this type of geologic province is not frequently targeted in studies of groundwater As exposure, since aquifers of sediments and sedimentary rocks typically yield more water for drinking supplies (Smedley and Kinniburgh 2002). Recent studies (e.g. O'Shea et al. 2015, Ryan et al. 2015) draw awareness to metamorphic aquifers as potential As hosts, but attention to volcanic rocks remains in deficit.

Mukherjee et al. (2014) hypothesize that geogenic As in groundwater may ultimately be sourced to deep earth processes. A key component of their proposed global As system is As mobilization by subduction zone magmas (Ballantyne and Moore 1988, Breuer and Pichler 2013, Mukherjee et al. 2014). During this process, subducted slabs and overlying sediments release water and soluble elements (e.g. As, $\mathrm{Pb}, \mathrm{Sb}$ ), which hydrate and enrich overlying serpentinites (Hattori and Guillot 2003). With further downward movement of the subducting slab the serpentinite layer transports these fluid-soluble elements to depth. Eventually dehydration of serpentinites occurs, releasing the slab-transported soluble elements and water, leading to partial melting of the mantle wedge and enrichment of such elements in volcanic arc fronts (Hattori and Guillot 2003). However, as recommended by Mukherjee et al. (2014), targeted field studies are required to enhance understanding of As cycling in these volcanic arc settings.

The Santiago Peak Volcanics (SPV) of Southern California (CA), USA and Northern Baja CA, Mexico are remnants of a subaerial volcanic arc that evolved along the west coast of North America during the Cretaceous. In studies by Herzig and Kimbrough (2014) of SPV 
outcropping in the Northern Santa Ana mountains, parental magmas were likely derived from a shallow, hydrous source magma followed by up to $10 \%$ assimilation of continental crust. Rocks range in composition from basalt to rhyolite and likely underwent syn-volcanic greenschist facies metamorphism (Herzig and Kimbrough 2014).

Historical records indicate that the portion of the SPV cropping out $100 \mathrm{~km}$ south of the Northern Santa Ana SPV, at Black Mountain Open Space Park (San Diego, CA) was once mined for As (Stewart 1963), providing a unique opportunity to present an integrated view of the interactions between observed As anomalies and volcanic arc processes through targeted field study. The goals of this work are threefold: (1) confirm the volcanic arc provenance of rocks cropping out at Black Mountain, (2) investigate As enrichment in relation to volcanic arc processes, and (3) propose a model for As occurrence in the SPV. Such analysis may enhance understanding of As transport by subduction zone magmas and provide insight into the preferential concentration of As in volcanic arc rocks, which may aid in identifying areas that are susceptible to groundwater elevated in As (Mukherjee et al. 2014). 


\subsection{Study area}

We examined SPV exposed at the surface of Black Mountain Open Space Park. The 950hectare park is located in the Rancho Peñasquitos Community of northern San Diego (population density $=\sim 1,500$ people $/ \mathrm{mi}^{2}$ ). The park encompasses most of Black Mountain, the highest peak $(460 \mathrm{~m})$ in the community, and surface water within the park drains into channels that eventually empty into the San Dieguito River. However, rainfall can be limited $(<30 \mathrm{~cm} / \mathrm{yr})$ in this semiarid region of the Southwestern coast of the USA (Fig 2.1b). Field mapping produced a 1:30,000 geologic map (Fig 2.1a) for Black Mountain. Portions of the park surrounding abandoned mines were mapped with greater resolution and indicate that the lithology of Black Mountain SPV varies over a spatial scale of tens of meters. 


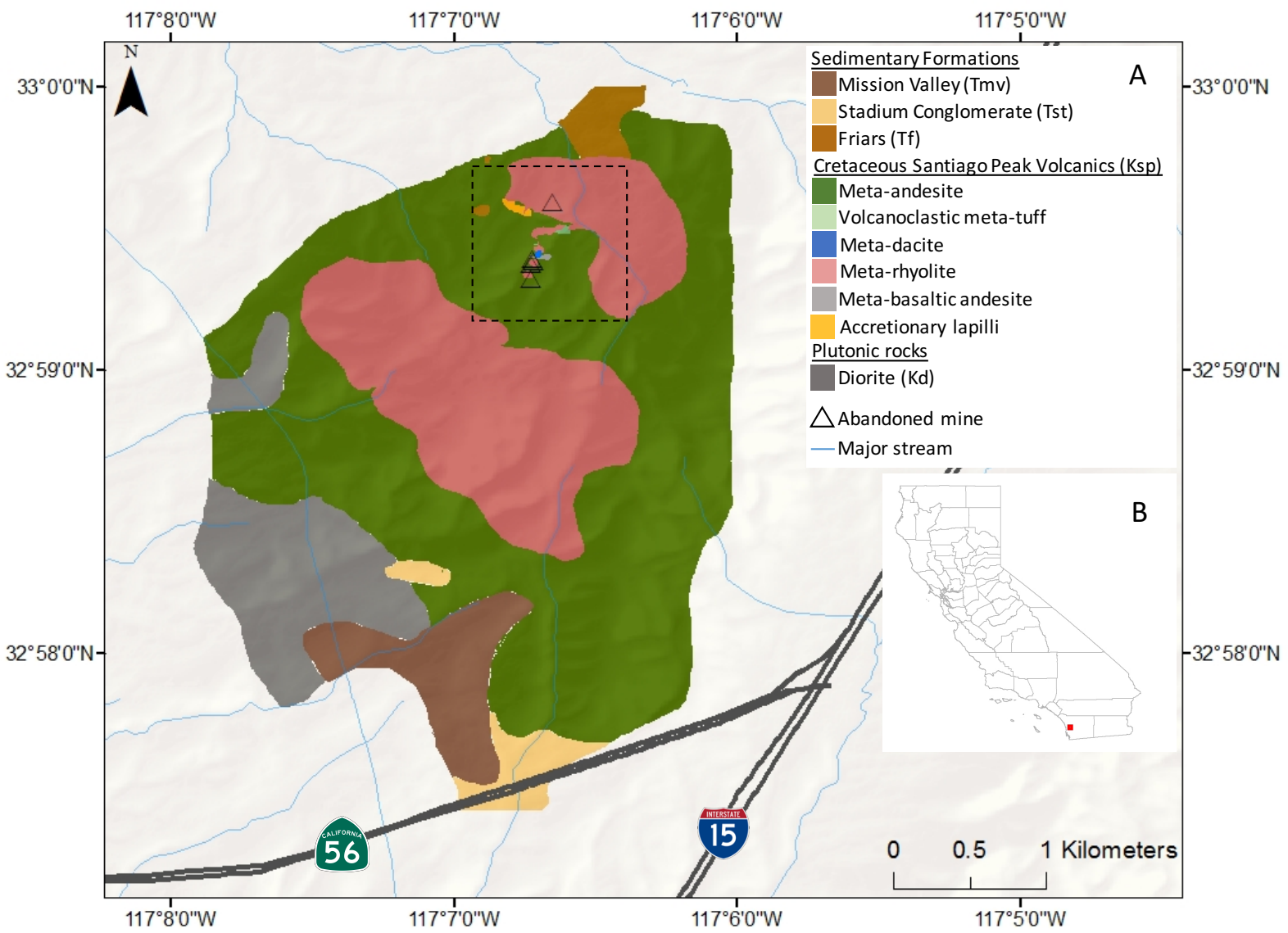

Fig 2.1: a) 1:30,000 geologic map of Black Mountain Open Space Park. Dotted line shows study area, b) Location of study area in San Diego County, California, USA. 


\subsection{Methods}

\subsubsection{Sample collection}

Following geological mapping and preliminary elemental analysis by field portable X-ray fluorescence (XRF, Haffert and Craw 2009), we collected 20 rock samples from in-situ outcrops at Black Mountain Open Space Park. Sampling was primarily focused around a $1 \mathrm{~km}^{2}$ area surrounding abandoned mines (Fig 2.1). Though outcrops were limited and sometimes inaccessible, we sampled multiple lithologies so that the extent of heterogeneity is represented in the sample population.

\subsubsection{Sample preparation}

Bulk rock samples $(n=20)$ were pulverized into a fine powder using a Bico Pulverizer fitted with ceramic plates at the University of San Diego (USD). Though samples had undergone various extents of weathering, we targeted fresh portions of coherent samples by removing weathering rinds using a diamond-tipped Dremel tool. Powdered rocks were sieved to $<53$ microns before fusion. A representative subset of samples $(\mathrm{n}=10)$ were cut into thin section for analysis by petrographic microscope. All equipment was routinely cleaned with acetone and compressed air to avoid cross contamination between samples.

\subsubsection{Lithology}

We analyzed thin sections following Perkins and Henke (2004) using a standard polarizing petrographic microscope at USD.

\subsubsection{Bulk rock geochemistry}

We examined major element composition using an XRF (Rigaku ZSX Primus II) at the College of Wooster following methods of Pollock et al. (2014). The resulting major element concentrations were used to characterize rock type by total alkali versus silica (TAS, Le Bas et 
al. 1985) and Jensen Cation (Le Maitre et al. 1989) plots, since samples could have undergone metasomatic loss of alkalis during greenschist facies alteration (Rollinson 1993).

\subsubsection{Trace metals}

Bulk rock samples were analyzed for trace metals by an Innov-X-5000 X-ray Fluorescence (XRF) at USD. Before each analysis, the XRF passed calibration by reference to a factory provided calibration disc. The Certified Reference Material (CRM) NIST 2710a Montana I Soil was analyzed for data quality assurance before, after, and during analysis of rock powders. Accuracy was assessed by calculating relative percent difference (RPD) from the certified concentration. Duplicates were assessed by calculating relative standard deviation (RSD), and only elements with RSD at or below 5\% precision are included in this report (Table 1).

Table 2.1: QA/QC for Innov-X-5000

\begin{tabular}{|c|c|c|c|c|c|}
\hline Sample ID & As (ppm) & $\mathrm{Cu}$ (ppm) & $\mathrm{Zn}(\mathrm{ppm})$ & $\mathrm{Pb}(\mathrm{ppm})$ & $\mathrm{Sb}$ (ppm) \\
\hline NIST 2710a (1) & 1,520 & 3,210 & 4,136 & 5,271 & 50 \\
\hline NIST 2710a (2) & 1,517 & 3,228 & 4,151 & 5,276 & 49 \\
\hline NIST 2710a (3) & 1,544 & 3,244 & 4,170 & 5,283 & 53 \\
\hline NIST 2710a (4) & 1,559 & 3,283 & 4,192 & 5,325 & 50 \\
\hline NIST 2710a (5) & 1,558 & 3,255 & 4,207 & 5,310 & 51 \\
\hline NIST 2710a (6) & 1,563 & 3,340 & 4,260 & 5,389 & 50 \\
\hline $\begin{array}{l}\text { NIST } 2710 \text { a certified } \\
\text { value }\end{array}$ & 1,540 & 3,420 & 4,180 & 5,520 & 52.5 \\
\hline \% RSD* & $1 \%$ & $1 \%$ & $1 \%$ & $1 \%$ & $3 \%$ \\
\hline \% RPD** & $0 \%$ & $-5 \%$ & $0 \%$ & $-4 \%$ & $-4 \%$ \\
\hline
\end{tabular}




\subsubsection{Lithology}

Volcanic outcrops in the study area consist of crystallized lava flows (Fig 2.2a), welded tuff (Fig 2.2b), and volcaniclastic (epiclastic) rocks (Fig 2.2c). Subaerial eruptive features include vesicles, flow banding (Fig 2.2a), pumice fragments (Fig 2.2c), and accretionary lapilli (Fig 2.2d). We did not observe features indicative of subaqueous volcanic eruption. All coherent samples were porphyritic, containing relatively fresh crystals of quartz (Qtz, Fig 2.2e), plagioclase (Plag, Fig 2.2b), and pyrite (Py, Fig 2.2b), with plagioclase being the most abundant phenocryst type. However, many phases were pseudomorphs composed of greenschist minerals chlorite (Cl), epidote (Ep), and zoisite (Zo) (Fig 2.2f, Fig 2.2g). We also observed sericite (Ser) in some rhyolitic samples ( $\mathrm{n}=3$, Fig $2.2 \mathrm{i})$. 


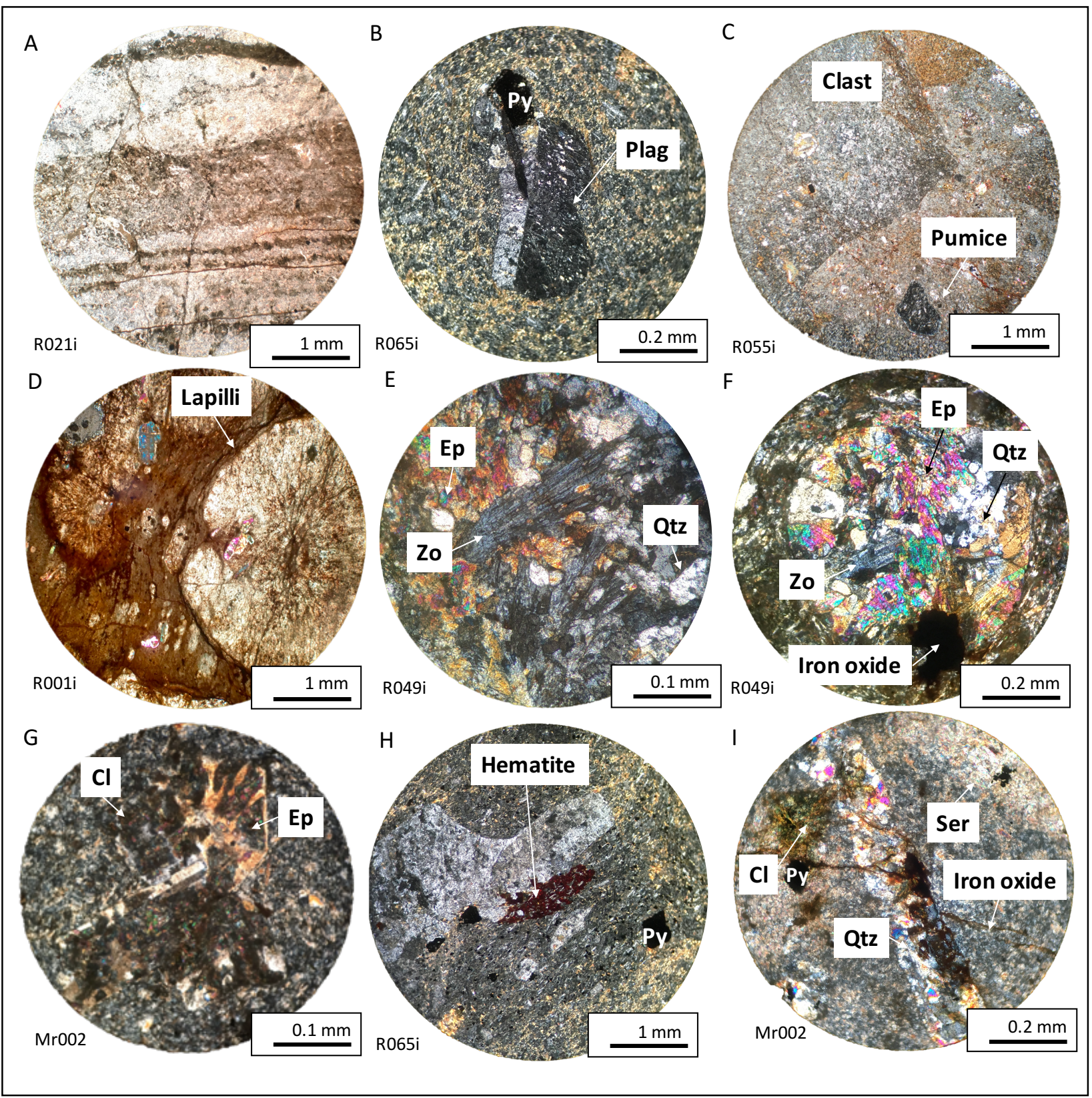

Fig 2.2: Photomicrographs taken in cross-polarizing light showing: a) Minimally altered rhyolite (R021i) exhibiting flow banding, b) Altered dacitic welded tuff (R065i) containing relatively fresh phenocrysts of plagioclase (Plag) and pyrite (Py), c) Altered volcaniclastic dacite (R055i), d) Accretionary lapilli, e) Moderately altered dacite (R049i) containing quartz (Qtz) phenocryst, with zoisite (Zo) and epidote (Ep) bordering phenocryst, f) Altered phenocryst containing quartz (Qtz), epidote (Ep), zoisite (Zo), and minor iron oxide in a moderately altered dacite (R049i), g)

Twinned plagioclase phenocrysts in an altered rhyolite (Mr002) that have been almost completely replaced by chlorite $(\mathrm{Cl})$ and epidote $(\mathrm{Ep}), \mathrm{h})$ Moderately altered dacitic welded tuff (R065i) containing hematite and pyrite (Py), and i) Highly altered rhyolite (Mr002) containing sericite (Ser), chlorite $(\mathrm{Cl})$, and pyrite $(\mathrm{Py})$. 


\subsubsection{Bulk geochemistry}

Jensen Cation (Fig 2.3a, Le Maitre et al. 1989) and TAS (Fig 2.3b, Le Bas et al. 1985) plots of bulk rock samples identify sub-alkaline rhyolites, dacites, and minor andesites as the most abundant rock types in Black Mountain SPV, with lithology varying over a spatial scale of tens of meters (Fig. 2.1). We will hereafter use the Jensen Cation Plot (Fig 2.3a, Le Maitre et al. 1989) to classify Black Mountain SPV, thus our samples consist of volcanic rhyolites ( $\mathrm{n}=10)$ and dacites $(\mathrm{n}=10)$.

Rhyolites typically contained greater $\mathrm{SiO}_{2}\left(\right.$ mean $\left.=74.09 \pm 2.13^{1} \mathrm{wt} \%\right), \mathrm{Na}_{2} \mathrm{O}($ mean $=4.81$ $\pm 0.27 \mathrm{wt} \%)$, and $\mathrm{K}_{2} \mathrm{O}\left(\right.$ mean $=2.35 \pm 0.25 \mathrm{wt} \%$ ), while dacites were enriched in $\mathrm{Al}_{2} \mathrm{O}_{3}$ (mean $=$ $16.84 \pm 0.52 \mathrm{wt} \%), \mathrm{Fe}_{2} \mathrm{O}_{3}($ mean $=9.07 \pm 0.35 \mathrm{wt} \%), \mathrm{CaO}($ mean $=5.56 \pm 1.03 \mathrm{wt} \%), \mathrm{MgO}$ $($ mean $=1.7 \pm 0.20 \mathrm{wt} \%)$, and $\mathrm{MnO}($ mean $=0.15 \pm 0.01 \mathrm{wt} \%)($ Table 2$)$. We observed overall trends of decreasing $\mathrm{Al}_{2} \mathrm{O}_{3}\left(\mathrm{R}^{2}=0.86\right), \mathrm{Fe}_{2} \mathrm{O}_{3}\left(\mathrm{R}^{2}=0.87\right), \mathrm{MgO}\left(\mathrm{R}^{2}=0.53\right), \mathrm{CaO}\left(\mathrm{R}^{2}=0.66\right)$, and $\mathrm{TiO}_{2}\left(\mathrm{R}^{2}=0.82\right)$ relative to $\mathrm{SiO}_{2}$, while $\mathrm{K}_{2} \mathrm{O}\left(\mathrm{R}^{2}=0.34\right)$ and $\mathrm{Na}_{2} \mathrm{O}\left(\mathrm{R}^{2}=0.24\right)$ are positively correlated with $\mathrm{SiO}_{2}$ (Fig 2.4). Black Mountain SPV lavas show Fe enrichment consistent with the tholeiitic magma series (Fig 2.5, Rollinson 1993).

\footnotetext{
${ }^{1}$ Standard error $=\frac{\text { Standard deviation }(\sigma)}{\sqrt{\text { Sample size }(\mathrm{n})}}$
} 

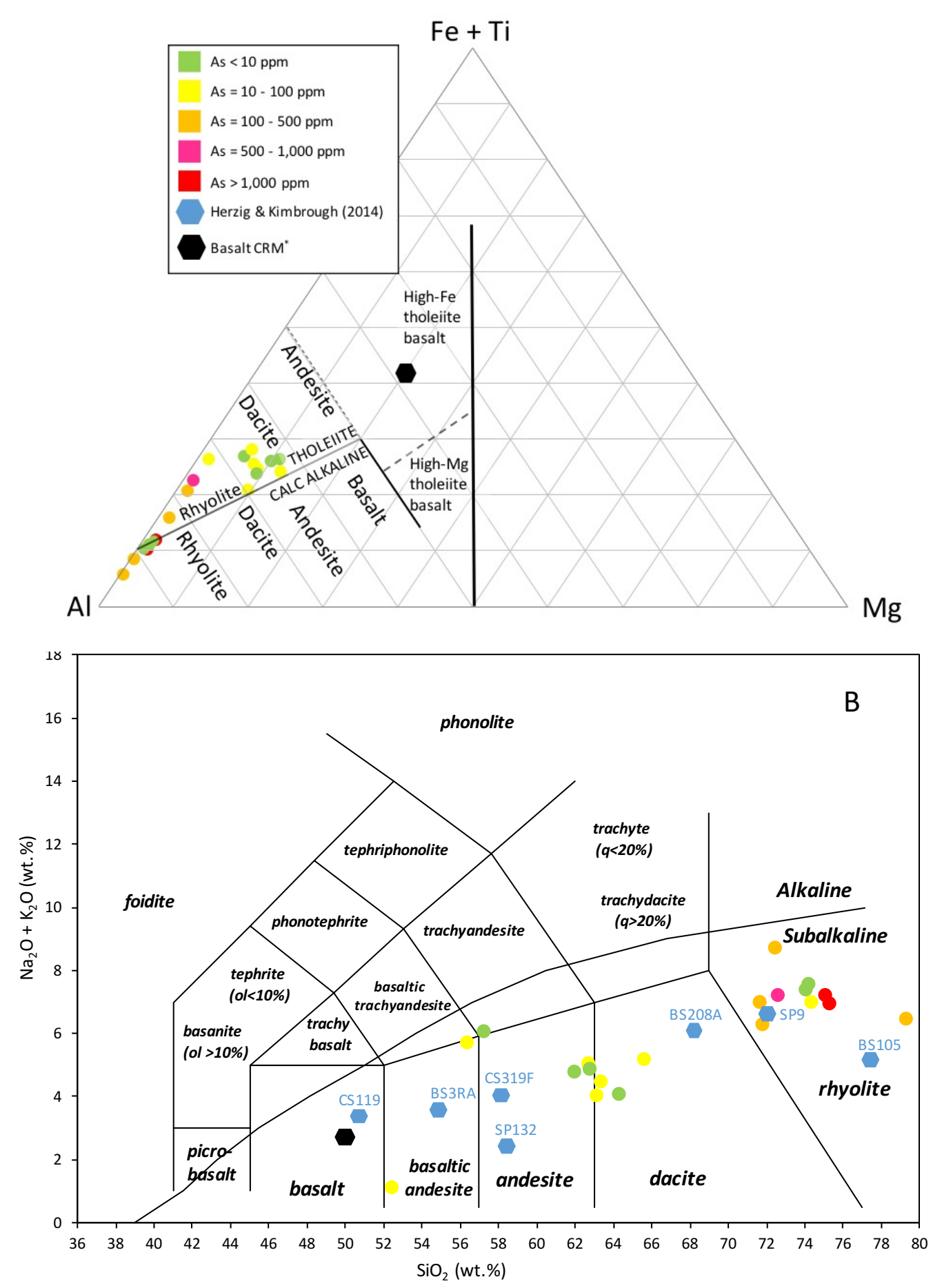

*: Certified Reference Material (CRM). Basalt, Hawaii Volcanic observatory, BHVO-2 (Wilson, S.A. 1998).

Fig 2.3: a) Jensen Cation (Le Maitre et al. 1989) and b) TAS (Le Bas et al. 1985) plotting of cations measured in rock samples presented in Table 2. Samples are differentiated by As concentration. For comparison, blue hexagons show geochemistry of SPV in the northern Santa Ana Mountains (Herzig and Kimbrough 2014). CRM provided for reference. 

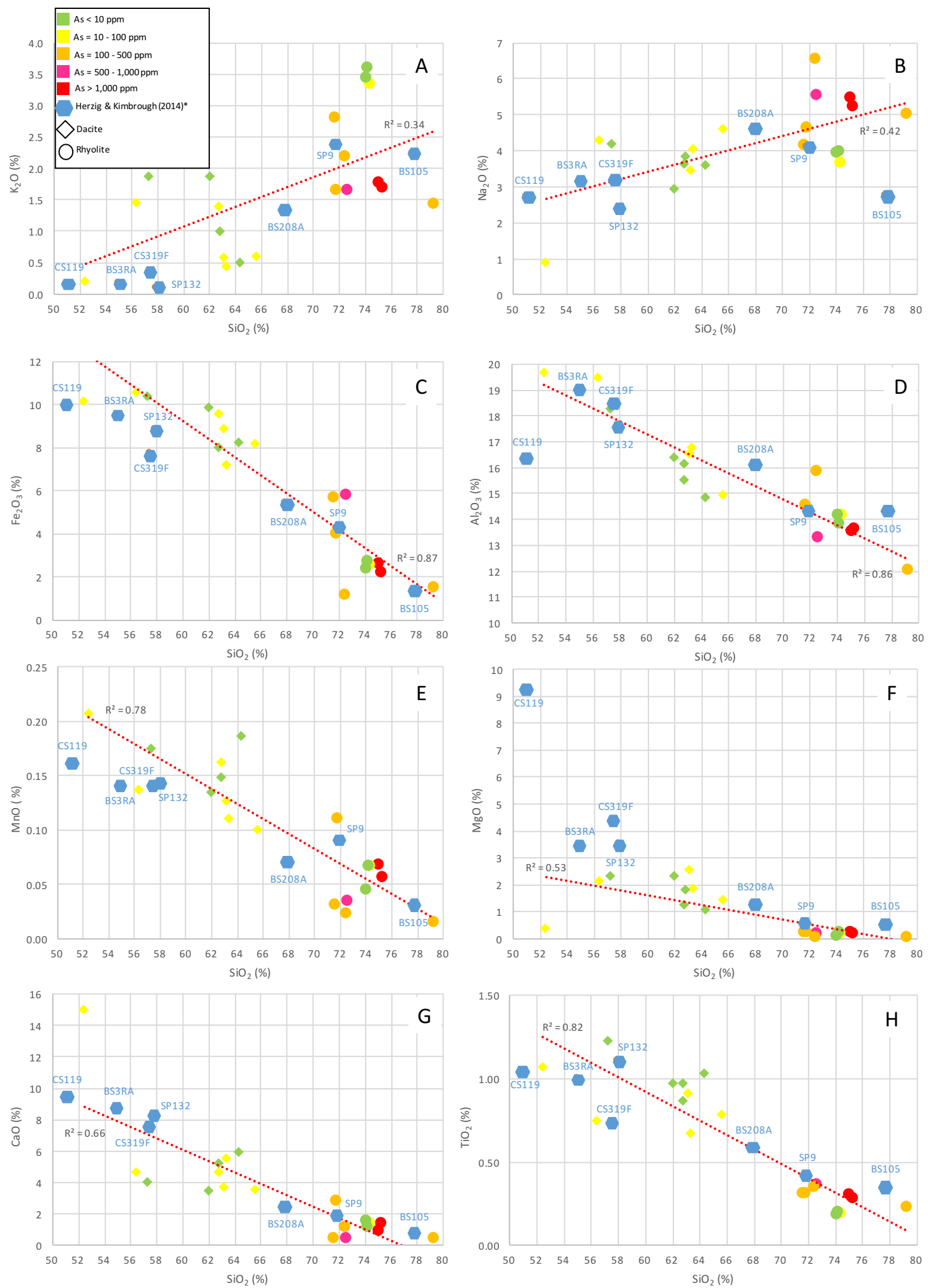

Fig 2.4: Bivariate plots showing concentration of $\mathrm{SiO}_{2}$ relative to a) $\mathrm{K} 2 \mathrm{O}$, b) $\mathrm{Na}_{2} \mathrm{O}$, c) $\mathrm{Fe}_{2} \mathrm{O}_{3}$ tot, d) $\mathrm{Al}_{2} \mathrm{O}_{3}$, e) $\mathrm{MnO}$, f) $\mathrm{MgO}$, g) $\mathrm{CaO}$, and f) $\mathrm{TiO}_{2}$. Colors indicate relative As enrichment. 


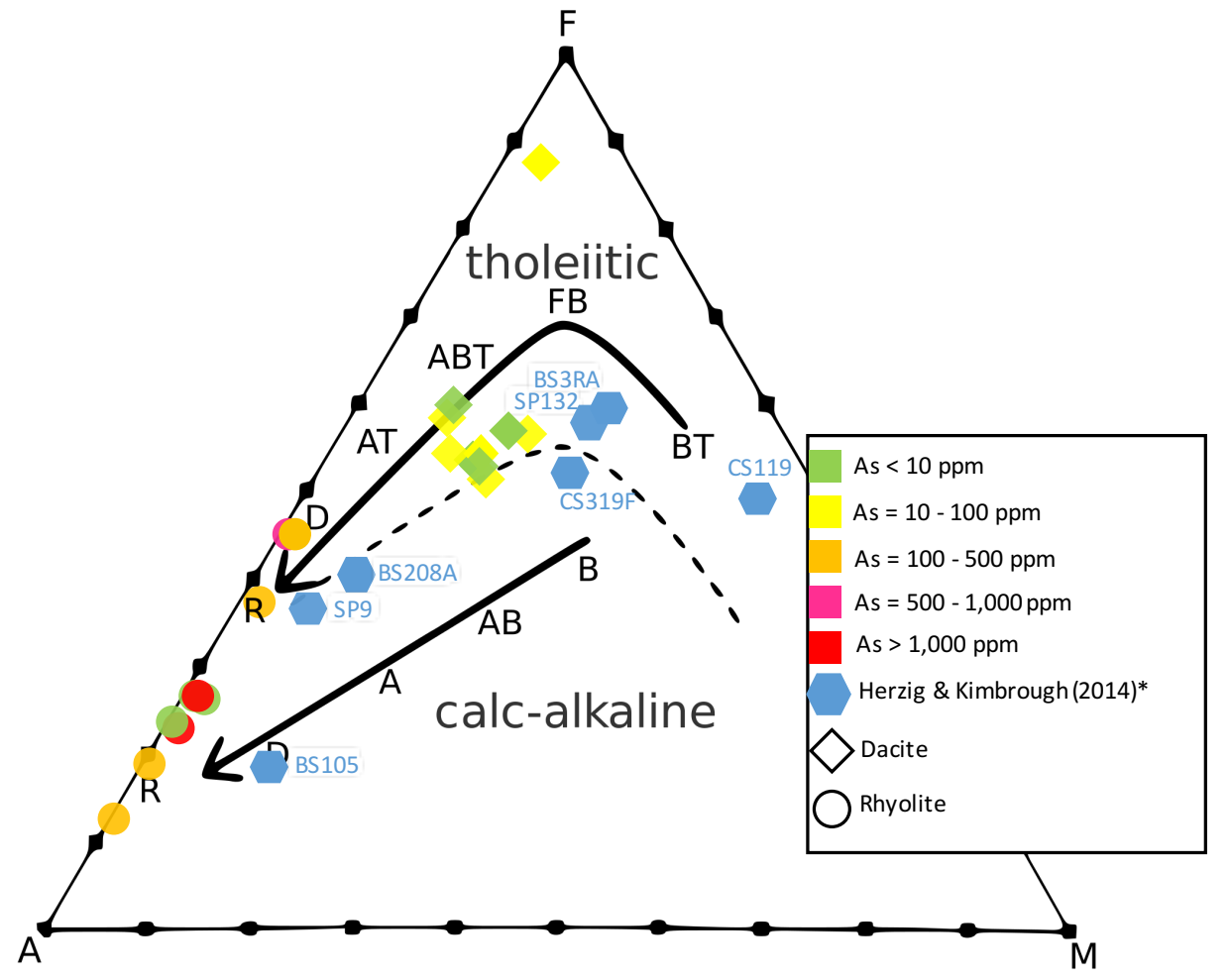

* Northern Santa Ana Mountain SPV whole rock geochemical data from Herzig \& Kimbrough (2014), Table 5.

Fig 2.5: AFM ( $\mathrm{A}-$ alkalis $\left(\mathrm{Na}_{2} \mathrm{O}+\mathrm{K}_{2} \mathrm{O}\right), \mathrm{F}$ - total iron $\left.\left(\mathrm{Fe}_{2} \mathrm{O}_{3}\right), \mathrm{M}-\mathrm{MgO}\right)$ Diagram for lavas of the Santiago Peak Volcanics. $\mathrm{BT}=$ tholeiitic basalt, $\mathrm{FB}=$ ferro-basalt, $\mathrm{ABT}=$ tholeiitic basaltic andesite, $\mathrm{AT}=$ tholeiitic andesite, $\mathrm{D}=$ dacite, $\mathrm{R}=$ rhyolite, $\mathrm{B}=$ basalt, $\mathrm{AB}=$ basaltic andesite.

Colors indicate relative As enrichment. 
Table 2.2: Major element composition of bulk rock samples $(\mathrm{n}=20)$.

\begin{tabular}{|c|c|c|c|c|c|c|c|c|c|c|c|c|c|}
\hline Sam & Roc & & MgO & $\mathrm{Al}_{2} \mathrm{O}_{3}$ & $\mathrm{SiO}_{2}$ & $\mathrm{P}_{2} \mathrm{O}_{5}$ & $\mathrm{~K}_{2} \mathrm{O}$ & $\mathrm{CaO}$ & $\mathrm{TiO}_{2}$ & MnO & $\mathrm{Fe}_{2} \mathrm{O}_{3}$ tot & $\mathrm{BaO}$ & Total \\
\hline & & & & & $15 s \%$ & & & ss \% & & ss \% & & mass $\%$ & \\
\hline Mr001 & Rhyolite & 5.01 & 0.06 & 12.00 & 79.28 & 0.00 & 1.43 & 0.40 & 0.23 & 0.01 & 1.49 & 0.09 & 100 \\
\hline Mr002 & & 5.23 & 0.17 & 13.63 & 75.32 & 0.03 & 1.69 & 1.36 & 0.28 & 0.06 & 2.16 & 0.08 & 100 \\
\hline R004i & Rhyolite & 4.15 & 0.24 & 14.52 & 71.66 & 0.03 & 2.81 & 0.44 & 0.31 & 0.03 & 5.67 & 0.14 & 100 \\
\hline R020i & Rhyolite & 5.45 & 0.21 & 13.53 & 75.07 & 0.03 & 1.76 & 0.89 & 0.30 & 0.07 & 2.60 & 0.09 & 100 \\
\hline R021i & Rhyolite & 3.65 & 0.17 & 14.15 & 74.36 & 0.06 & 3.33 & 1.41 & 0.19 & 0.07 & 2.56 & 0.07 & 100 \\
\hline R024wp & Rhyolite & 5.54 & 0.20 & 13.30 & 72.62 & 0.03 & 1.65 & 0.40 & 0.36 & 0.03 & 5.77 & 0.09 & 100 \\
\hline R037i & Rhyolite & 6.53 & 0.06 & 15.86 & 72.48 & 0.04 & 2.18 & 1.14 & 0.35 & 0.02 & 1.14 & 0.19 & 100 \\
\hline R044i & Rhyolite & 4.62 & 0.21 & 14.41 & 71.83 & 0.01 & 1.65 & 2.79 & 0.31 & 0.11 & 3.98 & 0.07 & 100 \\
\hline R046i & & 3.95 & 0.21 & 13.83 & 74.22 & & 3.59 & 1.15 & 0.20 & 0.07 & & 0.07 & 100 \\
\hline R060i & Rhyolite & 3.94 & 0.11 & 14.17 & 74.10 & 0.01 & 3.43 & 1.58 & 0.18 & 0.04 & 2.37 & 0.07 & 100 \\
\hline Average & Rhyolite & 4.81 & 0.16 & 13.94 & 74.09 & 0.03 & 2.35 & 1.16 & 0.27 & 0.05 & 3.04 & 0.10 & 100 \\
\hline Standard error & Rhyolite & \pm 2.7 & \pm 0.02 & \pm 0.30 & \pm 0.67 & \pm 0.00 & \pm 0.26 & \pm 0.22 & \pm 0.02 & \pm 0.01 & \pm 0.48 & \pm 0.01 & \\
\hline R038i & te & 0.90 & 0.35 & 19.66 & 52.43 & 0.07 & 0.19 & 14.98 & 1.06 & 0.21 & 10.14 & 0.01 & 100 \\
\hline R039i & Dacite & 4.03 & 1.83 & 16.74 & 63.34 & 0.14 & 0.43 & 5.54 & 0.67 & 0.11 & 7.15 & 0.03 & 100 \\
\hline R049i & Dacite & 3.58 & 1.06 & 14.82 & 64.32 & 0.38 & 0.49 & 5.93 & 1.03 & 0.19 & 8.19 & 0.02 & 100 \\
\hline R051i & Dacite & 3.44 & 2.55 & 16.54 & 63.15 & 0.14 & 0.57 & 3.69 & 0.91 & 0.13 & 8.87 & 0.03 & 100 \\
\hline R053i & Dacite & 3.64 & 1.25 & 15.52 & 62.74 & 0.20 & 1.39 & 4.63 & 0.87 & 0.16 & 9.56 & 0.05 & 100 \\
\hline R054i & Dacite & 4.19 & 2.30 & 18.26 & 57.29 & 0.25 & 1.86 & 4.03 & 1.23 & 0.18 & 10.36 & 0.07 & 100 \\
\hline R055i & Dacite & 2.92 & 2.31 & 16.35 & 62.02 & 0.13 & 1.87 & 3.44 & 0.97 & 0.13 & 9.82 & 0.05 & 100 \\
\hline R058i & Dacite & 4.59 & 1.44 & 14.95 & 65.60 & 0.26 & 0.60 & 3.52 & 0.78 & 0.10 & 8.14 & 0.02 & 100 \\
\hline R065i & Dacite & 4.27 & 2.12 & 19.45 & 56.40 & 0.18 & 1.44 & 4.66 & 0.74 & 0.14 & 10.54 & 0.06 & 100 \\
\hline R066i & Dacite & 3.84 & 1.79 & 16.12 & 62.79 & 0.19 & 1.00 & 5.16 & 0.97 & 0.15 & 7.97 & 0.04 & 100 \\
\hline Average & Dacite & 3.54 & 1.7 & 16.84 & 61.01 & 0.19 & 0.98 & 5.56 & 0.92 & 0.15 & 9.07 & 0.04 & 100 \\
\hline Standard error & Dacite & \pm 0.31 & \pm 0.20 & \pm 0.52 & \pm 1.26 & \pm 0.03 & \pm 0.19 & \pm 1.03 & \pm 0.05 & \pm 0.01 & \pm 0.35 & \pm 0.01 & \\
\hline $\mathrm{BHVO}^{+} 2^{+}$ & Basalt CRM & 2.20 & 7.11 & 13.55 & 49.99 & 0.26 & 0.51 & 11.29 & 2.70 & 0.17 & 12.20 & 0.01 & 100 \\
\hline $\begin{array}{l}\text { verage in upper- } \\
\text { crust* }\end{array}$ & & 3.27 & 2.43 & 15.40 & 66.62 & 0.15 & 3.27 & 3.59 & 0.64 & 0.10 & 5.04 & 0.07 & \\
\hline
\end{tabular}

${ }^{+}$: Certified Reference Material (CRM). Basalt, Hawaii Volcanic observatory, BHVO-2 (Wilson, S.A. 1998).

*: Rudnick and Gao (2003) 


\subsubsection{Trace metal enrichment}

Total As in Black Mountain SPV $(\mathrm{n}=20)$ ranged from $5.2 \mathrm{ppm}$ to 3,155 ppm. In addition to As, all samples contained copper $(\mathrm{Cu})$, lead $(\mathrm{Pb})$, and zinc $(\mathrm{Zn})$. We detected antimony $(\mathrm{Sb})$ in only a few $(n=2)$ samples. Rhyolites were typically more enriched in As $(n=10$, mean $=586 \pm$ $10 \mathrm{ppm}$ As) than dacites $(\mathrm{n}=10$, mean $=14 \pm 9 \mathrm{ppm}$ As $)$. Rhyolites also contained greater concentrations of $\mathrm{Pb}($ mean $=28 \pm 4 \mathrm{ppm} \mathrm{As})$, while dacites were more enriched in $\mathrm{Zn}($ mean $=$ $114 \pm 13$ ppm). Rhyolites and dacites had similar average $\mathrm{Cu}$ concentrations ( $\sim 30 \mathrm{ppm})$ (Table 3). 
Table 2.3: Summary of trace element enrichment in Black Mountain SPV. Mean +/- standard error.

\begin{tabular}{rccccc}
\hline & As (ppm) & $\mathrm{Cu}(\mathrm{ppm})$ & $\mathrm{Pb}(\mathrm{ppm})$ & $\mathrm{Sb}$ (ppm) & Zn (ppm) \\
\hline Bulk rhyolites $(\mathrm{n}=10)$ & $586+/-10$ & $30+/-6$ & $28+/-4$ & $4+/-3$ & $46+/-8$ \\
Bulk dacites $(\mathrm{n}=10)$ & $14+/-9$ & $30+/-3$ & $12+/-2$ & $\mathrm{ND}$ & $114+/-13$ \\
Average in upper-crust* & 4.8 & 28 & 17 & 0.4 & 47 \\
\hline
\end{tabular}

*: Rudnick and Gao (2003) 


\subsection{Discussion}

\subsubsection{Volcanic arc provenance of rocks outcropping at Black Mountain}

Given the geochemical similarities between Black Mountain SPV and Northern Santa Ana Mountain SPV (Herzig and Kimbrough 2014), we suspect that the two units evolved within the same volcanic arc system during the Cretaceous. Our hypothesis is supported by several lines of evidence. First, we observed welded tuffs, volcaniclastic (epiclastic) rocks, and accretionary lapilli in Black Mountain SPV, which suggest that several distinct stages of subaerial volcanic eruption occurred (Abbott et al. 1993, Herzig and Kimbrough 2014).

Second, we found that lavas were often porphyritic and ranged in composition from dacite to rhyolite (Fig 2.3), with rhyolites containing more $\mathrm{SiO}_{2}, \mathrm{Na}_{2} \mathrm{O}$, and $\mathrm{K}_{2} \mathrm{O}$ than dacites (Fig. 2.4). Like Herzig and Kimbrough (2014), we also observed overall trends of decreasing $\mathrm{Al}_{2} \mathrm{O}_{3}, \mathrm{Fe}_{2} \mathrm{O}_{3}, \mathrm{MgO}, \mathrm{CaO}$, and $\mathrm{TiO}_{2}$ relative to $\mathrm{SiO}_{2}$ (Fig 2.4). Such trends are qualitatively consistent with low-pressure fractional crystallization of hydrous mafic magmas (Rollinson 1993 ) and, thus, suggest that rhyolites crystallized from more evolved melts than dacites.

Finally, all samples analyzed in thin section contain evidence of varying extents of synvolcanic alteration (Fig 2.1). Though greenschist facies minerals (e.g. chlorite, epidote, zoisite) often replaced primary igneous phases (e.g. plagioclase) in highly altered samples, we found no evidence of penetrative cleavage indicative of a regional metamorphic event (Fig 2.1). Therefore, our findings corroborate the hypothesis that greenschist facies alteration of SPV occurred contemporaneously with arc volcanism (Herzig and Kimbrough 2014). 


\subsubsection{Arsenic enrichment in relation to volcanic arc processes}

We found that As content varied between the two dominant SPV rock types, with rhyolites typically containing more As $(n=10$, mean $=586 \pm 10 \mathrm{ppm} \mathrm{As})$ than dacites $(\mathrm{n}=10$, mean $=14 \pm 9 \mathrm{ppm} \mathrm{As}$ ) (Table 2.2). This finding is particularly interesting because typically igneous rocks report low (close to crustal average; Table 2.3) concentrations of As. For example, Smedley and Kinniburgh (2001) report an average of $1.5 \mathrm{ppm}$ As for igneous rocks. The mean arsenic in these SPV rhyolites is thus about 120 times greater than the averages reported for the upper crust, and nearly 400 times the average for igneous rocks as reported by Smedley and Kinniburgh (2001). Even dacites are enriched above crustal averages, further indicating that volcanic arcs are plausible host provinces of As-enriched volcanic rocks.

\subsubsection{Partial melt evolution}

The enrichment of As in rhyolites may explain the weak to moderate positive correlation we observed between As and $\mathrm{SiO}_{2}\left(\mathrm{R}^{2}=0.32\right)$ and $/ \mathrm{or} \mathrm{Na}_{2} \mathrm{O}\left(\mathrm{R}^{2}=0.43\right)$, as well as the negative correlation between As and $\mathrm{Fe}_{2} \mathrm{O}_{3}\left(\mathrm{R}^{2}=0.30\right), \mathrm{Al}_{2} \mathrm{O}_{3}\left(\mathrm{R}^{2}=0.24\right), \mathrm{MnO}\left(\mathrm{R}^{2}=0.33\right), \mathrm{MgO}\left(\mathrm{R}^{2}=\right.$ $0.33), \mathrm{CaO}\left(\mathrm{R}^{2}=0.17\right)$, and/or $\mathrm{TiO}_{2}\left(\mathrm{R}^{2}=0.28\right)($ Fig 2.6$)$, given that rhyolites are typically enriched in $\mathrm{SiO}_{2}$ and $\mathrm{Na}_{2} \mathrm{O}$, but depleted $\mathrm{Fe}_{2} \mathrm{O}_{3}, \mathrm{Al}_{2} \mathrm{O}_{3}, \mathrm{MnO}, \mathrm{MgO}, \mathrm{CaO}$, and $\mathrm{TiO}_{2}$ (Fig 2.4).

These trends (Fig 2.6) also demonstrate that As is negatively correlated with elements

( $\mathrm{Fe}, \mathrm{Al}, \mathrm{Mn}, \mathrm{Mg}, \mathrm{Ca}$, and $\mathrm{Ti}$ ) that are incorporated into minerals during the early stages of fractional crystallization, while As is positively correlated with elements ( $\mathrm{Si}$ and $\mathrm{Na}$ ) that incorporate into later-stage minerals. These findings suggest that As enrichment may be controlled, in part, by the fractional crystallization of partial melts, with rocks that crystallized from relatively evolved partial melts like these SPV rhyolites, containing greater As. The AFM diagram (Fig. 2.5), which gives As content in relation to tholeiitic differentiation trends, further 
supports this hypothesis. The diagram demonstrates that As enrichment in Black Mountain SPV increases as $\mathrm{Mg}$ and $\mathrm{Fe}$ content of magmas decrease. Thus, felsic rocks that crystallized from more evolved melts typically contain greater As.

Our interpretation is supported by the findings of Johnson et al. 2013 who analyzed rhyolites in the Taupo Volcanic Zone (TVZ) of New Zealand. This work suggests that, throughout the processes of fractional crystallization and extensive degassing, metals (e.g. As) do not partition into an exsolved vapor and instead partition into crystallizing minerals or remain dissolved in the melt until they are eventually exhumed in rhyolites (Johnson et al. 2013).

It is important to note that we observed a strong negative correlation between As and $\mathrm{K}_{2} \mathrm{O}\left(\mathrm{R}^{2}=0.80\right.$, Fig $\left.2.6 \mathrm{a}\right)$ in rhyolites, though greater $\mathrm{K}_{2} \mathrm{O}$ is typically associated with more evolved melts. The replacement of K-feldspar, albite, and/or sericite by Mg-Fe chlorite (Eq 1, Fig 2.2g) and/or pyrite (Fig 2.2b) during syn-volcanic hydrothermal alteration (Large et al. 2001) may explain this trend, since such reactions suggest that $\mathrm{K}_{2} \mathrm{O}$ is re-mobilized by hydrothermal fluids and, thus, may not be associated with the fractional crystallization of source melts.

Eq. 2.1: $2 \mathrm{KAl}_{3} \mathrm{Si}_{3} \mathrm{O}_{10}(\mathrm{OH})_{2}$ (sericite) $+3 \mathrm{H}_{4} \mathrm{SiO}_{4}+9 \mathrm{Fe}^{2+}+6 \mathrm{Mg}^{2+}+18 \mathrm{H}_{2} \mathrm{O} \rightarrow$ $3 \mathrm{Mg}_{2} \mathrm{Fe}_{3} \mathrm{Al}_{2} \mathrm{Si}_{3} \mathrm{O}_{10}(\mathrm{OH})_{8}$ (chlorite) $+2 \mathrm{~K}^{+}+28 \mathrm{H}^{+}$

Further, O'Shea et al. (2015) observed As enrichment in greenschist facies rocks containing chlorite and pyrite. In their study, arsenic was detected in pyrites when the index mineral chlorite was present, suggesting that pyrites, and potentially silicates like chlorites, are likely hosts of As in rocks subjected to greenschist facies metamorphism, like the SPV rhyolites. 

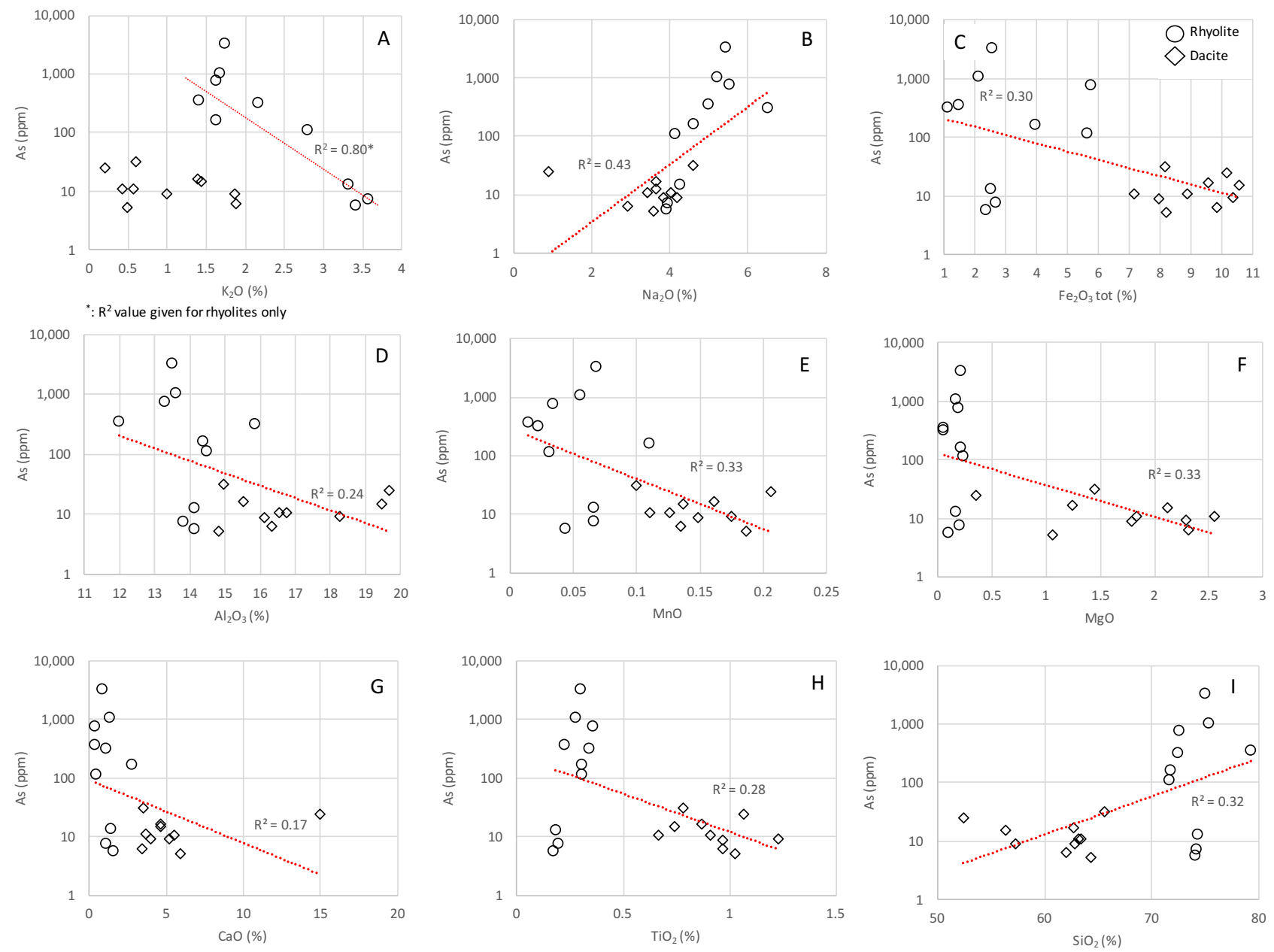

Fig 2.6: Bivariate plots comparing As content (ppm) to concentration of major ions (wt. \%), a) $\mathrm{K}_{2} \mathrm{O}$, b) $\mathrm{Na}_{2} \mathrm{O}$, c) $\mathrm{Fe}_{2} \mathrm{O}_{3}$ tot, d) $\mathrm{Al}_{2} \mathrm{O}_{3}$, e) $\left.\mathrm{MnO}, \mathrm{f}\right) \mathrm{MgO}$, g) $\mathrm{CaO}$, f) $\mathrm{TiO}_{2}$, and g) $\mathrm{SiO}_{2}$ 


\subsubsection{Arsenic mobility in subduction zone fluids}

Our findings of As enrichment in an ancient volcanic arc suggest that As in Black Mountain SPV may ultimately be sourced to deep earth subduction zone processes. Though neighboring intrusive igneous plutons of the western Peninsular Ranges Batholith (PRB) likely evolved from the same magma system as the SPV during the Late Cretaceous (Herzig and Kimbrough 2014), we are not aware of comparable degrees and/or extents of As enrichment elsewhere in the SPV or western PRB cropping out in Southern CA or Northern Baja CA, Mexico. Therefore, within the ancient subduction zone, As appears to be most enriched in rocks associated with ancient volcanic arc fronts (Noll et al. 1996).

Hattori and Guillot (2003) suggest that fluid-mobile elements, like As, $\mathrm{Sb}$, and $\mathrm{Pb}$, are enriched in volcanic arc fronts, because they are highly soluble in relatively low temperature aqueous fluids, allowing them to be easily volatilized from subduction zone serpentinites during dehydration and partial melting (Hattori and Guillot 2003). Other trace metals, like $\mathrm{Cu}$, are less soluble and, thus, mobilized at higher temperatures (Hack et al. 2006). Therefore, these less soluble metals may not be as enriched as highly soluble metals in volcanic fronts overlying ancient subduction zones.

We observed higher concentrations of highly soluble metals, $\mathrm{As}$ and $\mathrm{Pb}$, in rhyolites, but $\mathrm{Cu}$ was equally enriched in both rhyolites and dacites (Table 3). Zinc was much more enriched in dacites than rhyolites (Table 3), potentially resulting from its compatibility in ferromagnesian minerals (Stanton 1994, Johnson et al. 2013), like hornblende and biotite.

The high solubility of As and $\mathrm{Pb}$ initially caused these metals to be among the first released from subduction zone serpentinites during dehydration, leading to their initial enrichment in partial melts underlying volcanic arc fronts. Because of their incompatibility in 
these melts (Hattori and Guillot 2005), As and $\mathrm{Pb}$ remained dissolved as melts evolved from mafic to felsic and, thus, were eventually exhumed in rhyolitic lavas. Since $\mathrm{Cu}$ is not as soluble as $\mathrm{As}$ and $\mathrm{Pb}$ (Hattori and Guillot 2003, Hack et al. 2006), Cu may have been released from serpentinites during later stages of subduction. The equivalent $\mathrm{Cu}$ content in dacites and rhyolites suggests that $\mathrm{Cu}$ enrichment was associated with a syn-volcanic hydrothermal intrusion that occurred during later-stage subduction (Nadeau et al. 2013). 


\subsubsection{Model for arsenic occurrence in Black Mountain SPV}

Based on our results and incorporating the findings of others, we propose the following model to explain As enrichment in Black Mountain SPV (Fig 2.7):

1. During the Cretaceous, the oceanic Farallon Plate began to subduct beneath the continental North American Plate (Herzig and Kimbrough 2014), transporting oceanic sediment to depth.

2. At temperatures of around $650^{\circ} \mathrm{C}$, serpentinite dehydration releases water and soluble elements, which migrate upwards and hydrate and enrich the overlying mantle wedge in $\mathrm{As}$ and $\mathrm{Pb}$, in that order. Eventually, $\mathrm{As}$ and $\mathrm{Pb}$ are incorporated into the partial melt (Hattori and Guillot 2003).

3. Due to their high solubility and relative incompatibility (Hattori and Guillot 2003), $\mathrm{As}$ and $\mathrm{Pb}$ remain dissolved in the partial melt as it evolves from mafic to felsic and, thus, are eventually exhumed in rhyolitic magmas.

4. Because it is less soluble (Hack et al. 2006), $\mathrm{Cu}$ is released during later stages of serpentinite dehydration and, thus, likely has a different source melt than $\mathrm{As}$ and $\mathrm{Pb}$. 


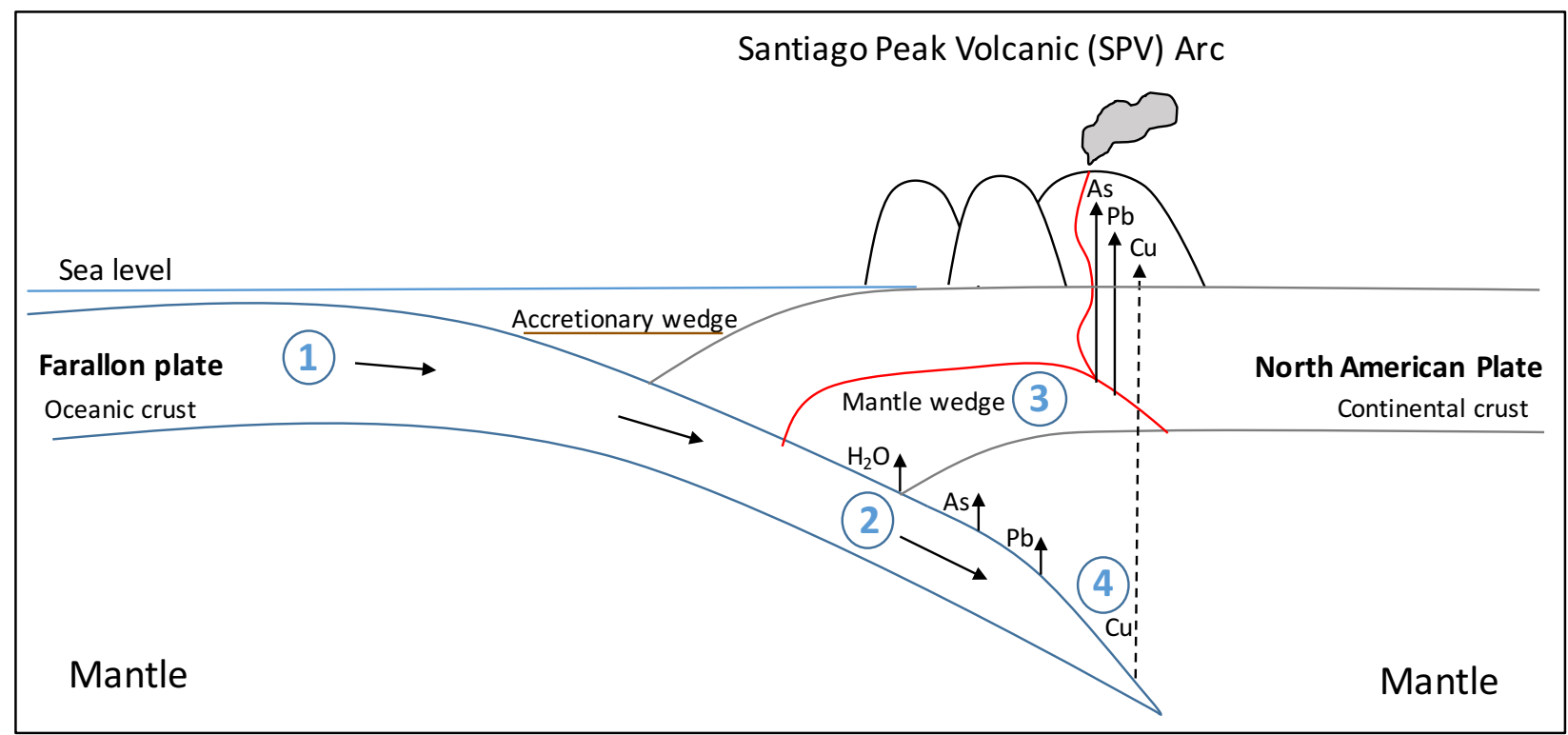

Figure 2.7: Model explaining the provenance of As in Black Mountain SPV 


\subsubsection{Potential for groundwater arsenic enrichment in Black Mountain SPV}

There are no domestic wells within a one mile radius of the study area, though groundwater is eligible for municipal use (CA EPA). Historic records report that, in wetter times, an As-rich spring existed (City of San Diego Cultural Report). Further, previous work in the Chaco-Pampean Plain of Argentina suggests that the dissolution of rhyolitic glass is the principle source for As in shallow groundwaters there (Raychowdury et al. 2014; Bunduschuh et al. 2004). Raychowdhury et al. (2014) proposed that volcanic host rocks that formed via ancient volcanic arc processes may produce groundwater elevated in As ( $>5 \mathrm{mg} / \mathrm{L})$. Therefore, any groundwater flowing through the Black Mountain SPV arsenic-rhyolite is likely to be extremely elevated in dissolved arsenic and, thus, may pose a significant health threat if consumed. 


\subsection{Summary}

- Black Mountain SPV evolved from the same magma system as Northern Santa Ana Mountain SPV (Herzig and Kimbrough 2014) during the Cretaceous.

- Arsenic enrichment in Black Mountain SPV is ultimately sourced to deep earth subduction zone processes as proposed globally by Mukherjee et al. (2014).

- Our proposed model for As enrichment in SPV (Fig 2.7) suggests that As is among the first elements released during serpentinite dehydration (along with $\mathrm{Pb}$ ), while less soluble elements (e.g. $\mathrm{Cu}$ ) are released during later stages of subduction.

- Once $\mathrm{As}$ and $\mathrm{Pb}$ are released from serpentinites and incorporated into partial melts (Hattori and Guillot 2003), we hypothesize that such elements behave like typical incompatible elements and remain dissolved in melts until they are eventually exhumed in rhyolitic lavas. 


\subsection{Conclusion}

Our findings of As in an ancient volcanic arc system support the hypothesis that groundwater As may ultimately be sourced to deep earth processes (Mukherjee et al. 2014). Therefore, As tends to be enriched in volcanic arc rocks and, thus, other modern or ancient volcanic arc systems (e.g. Cascade Volcanic Arc, Aleutian Arc, Andean Volcanic Belt) may be prone to groundwater As enrichment (Mukherjee et al. 2014). Our work suggests that, within these ancient volcanic arc systems, As enrichment is associated with volcanic rocks that crystallized from relatively evolved partial melts underlying the volcanic front (e.g. rhyolite). Given that As may dissolve out of volcanic host rocks in groundwater aquifers (Bundschuh et al. 2004, Raychowdhury et al. 2014), this enhanced understanding of As distribution among ancient volcanic arc rocks may aid in identifying alternative drinking water sources in regions with known groundwater As enrichment. 


\subsection{Work cited}

Abdelnasser, A., K. Mustafa, 2016. Mineral chemistry and geochemical behavior of hydrothermal alterations associated with mafic intrusive-related Au deposits at the Atud area, Central Eastern Desert, Egypt. Ore Geol. Reviews 77: 1-24.

Bove, D.J., M.A. Mast, B. Dalton, W.G. Winfield, 2012. Major styles of mineralization and hydrothermal alteration and related solid- and aqueous- phase geochemical signatures. In: Integrated Investigations of Environmental Effects of Historical Mining in the Animas River Watershed, San Juan County, Colorado. U.S. Geological Survey Professional Paper 1651, pp. 165-230.

Ballantyne, M., J. Moore, 1988. Arsenic geochemistry in geothermal systems. Geochim. Cosmochim. Acta 52 (2): 475-483.

Bissen, M., F.H. Frimmel, 2003. Arsenic - a review. Part 1: Occurrence, toxicity, speciation, mobility. Acta Hydroch. Hydrob. 31: 9-18.

Breuer, C., T. Pichler, 2013. Arsenic in marine hydrothermal fluids. Chem. Geol. 348: 2-14.

Bundschuh, J., B. Farias, R. Martin, A. Storniolo, P. Bhattacharya, J. Cortes, G. Bonorino, and R. Albouy, 2004. Groundwater arsenic in the Chaco-Pampean Plain, Argentina: case study from Robles county, Santiago del Estero province. Appl. Geochem. 19 (2): 231243.

Carrasco, A.P., D.L. Kimbrough, C.T. Herzig, G.L. Meeth, 1993. Discovery of accretionary lapilli in the Santiago Peak Volcanics of Southern and Baja California. In: Geologic Investigations in Baja California: South Coast Geological Society Annual Field Trip Guide Book 21: 145 - 149.

Drahota, P., M. Filippi, 2009. Secondary arsenic minerals in the environment: a review. Env. Int. 35: 1243-1255.

Dutrizac, J.E., 1983. Factors affecting alkali jarosite precipitation. Metallurgical Transactions B, 14(4): 531-539.

Fernandez-Martinez, A., G.J Cuello, M.R. Johnson, F. Bardelli, G. Roman-Ross, L. Charlet, X. Turrillas, 2008. Arsenate incorporation in gypsum probed by neutron, X-ray scattering and density functional theory modeling. J. of Phys. Chem. A, 112(23): 5159-5166.

Fife, D.L., J.A. Minch, and P.J. Crampton, 1967. Late Jurassic age of the Santiago Peak Volcanics, California: Geol. Society of America Bulletin 78: 299-304.

Green, T. H., A. E. Ringwood, 1966. Origin of the calc-alkaline igneous rock suite. Earth and Planetary Science Letters 1(5): 307-316. 
Hack, A.C., J.A. Mavrogenes, 2006. A synthetic fluid inclusion study of copper solubility in hydrothermal brines from 525 to $725 \mathrm{C}$ and 0.3 to $1.7 \mathrm{GPa}$. Geochim, et Cosmochim. Acta 70(15): 3970-3985.

Haffert, L., D. Craw, 2009. Field quantification and characterization of extreme arsenic concentrations at a historic mine processing site, Waiuta, New Zealand. New Zealand Journal of Geology and Geophysics 52: 261-271.

Hattori, K., Y. Takahashi, S. Guillot, B. Johanson, 2005. Occurrence of arsenic (V) in forearc mantle serpentinites based on X-ray absorption spectroscopy study. Geochim. et Cosmochim. Acta 69(23): 5585-5596.

Hattori, K.H., S. Guillot, 2003. Volcanic fronts form as a consequence of serpentinite on the forearc mantle wedge. Geol. 31(6): 525-528.

Henke, K., 2009. Arsenic: environmental chemistry, health threats and waste treatment. John Wiley \& Sons, pp. $69-235$.

Herzig, C.T., D.L. Kimbrough, 2014. Santiago peak volcanics: Early Cretaceous arc volcanism of the western Peninsular Ranges batholith, southern California. GSA Memoir 211: 345363.

Huston, D.L., S.H. Sie, G.F. Suter, D.R. Cooke, R.A. Both, 1995. Trace Elements in Minerals from Eastern Australian Volcanic-Hosted Massive Sulfide Deposits: Part I. Proton microprobe analyses of pyrite, chalcopyrite, and sphalerite, and Part II. Selenium levels in pyrite: comparison with $\delta^{34} \mathrm{~S}$ Values and Implications for the source of sulfur in volcanogenic hydrothermal systems. Econ. Geol. 90: 1167-1196.

Ishihara, S. 1978. Metallogenesis in the Japanese island arc system. J. of the Geol. Soc. 135: 389-406.

Johnson, E. R., V. S. Kamenetsky, J. McPhie, 2013. The Behavior of Metals (Pb, Zn, As, Mo, $\mathrm{Cu})$ During Crystallization and Degassing of Rhyolites from the Okataina Volcanic Center, Taupo Volcanic Zone, New Zealand. J. of Petrol. 54(8): 1641-1659.

Koski, R.A., D.L. Mosier, 2012. Deposit Type and Associated Commodities. In: Volcanogenic massive sulfide occurrence model: U.S. Geological Survey Scientific Investigations Report 2010-5070-C, pp. $13-21$.

Large, R., J. Gemmell, H. Paulick, D. Huston, 2001. The Alteration Box Plot: A simple approach to understanding the relationship between alteration mineralogy and lithogeochemistry associated with volcanic-hosted massive sulfide deposits. Econ. Geol. 96: 957-971.

Le Bas, M. J., R. Le Maitre, A. Streckeisen, B. Zanettin, 1986. A chemical classification of volcanic rocks based on the total alkali-silica diagram. J. of petrol. 27(3): 745-750. 
Le Maitre, R.W., P. Bateman, A. Dudek, J. Keller, J. Lameyre, M. Le Bas, P. Sabine, R. Schmid, H. Sorensen, A. Streckeisen, A. Woolley, 1989. A Classification of Igneous Rocks and Glossary of Terms, Recommendations of the International Union of Geological Sciences, Subcomission on the Systematics of Igneous Rocks. In: A classification of igneous rocks and glossary of terms: Recommendations of the International Union of Geological Sciences Subcommission on the Systematics of igneous rocks.

Majzlan, J., P. Drahota, M. Filippi, 2014. Parageneses and crystal chemistry of arsenic minerals. Reviews in Mineralogy and Geochemistry 79(1): 17-184.

Mandal, B.K., K.T. Suzuki, 2002. Arsenic round the world: a review. Talanta 58 (1), 201-235.

Mukherjee, A., S. Verma, S. Gupta, K.R. Henke, P. Bhattacharya, 2014. Influence of tectonics, sedimentation and aqueous flow cycles on the origin of global groundwater arsenic: Paradigms from three continents. J. of Hydrol. 518: 284-299.

Nadeau, O., J. Stix, A.E. Williams-Jones, 2013. The behavior of $\mathrm{Cu}, \mathrm{Zn}$ and $\mathrm{Pb}$ during magmatic-hydrothermal activity at Merapi volcano, Indonesia. Chem. Geol. 342: 167179.

Nadeau, O., Williams-Jones, A.E., Stix, J., 2010. Sulfide magma as a source of metals in arcrelated magmatic hydrothermal ore fluids. Nature Geoscience 3, 501-505.

Noll, P.D., H.E. Newsom, W.P. Leeman, J.G. Ryan, 1996. The role of hydrothermal fluids in the production of subduction zone magmas: Evidence from siderophile and chalcophile trace elements. Geochim. Cosmochim. Acta 60(4): 587 - 611.

O'Shea, B., M. Stransky, S. Leitheiser, P. Brock, R.G. Marvinney, Y. Zheng, 2015. Heterogeneous arsenic enrichment in meta-sedimentary rocks in central Maine, United States. Sci. Total Environ. 505: 1308 -1319.

Piercey, S.J., M.C. Devine, 2014. Analysis of powdered reference materials and known samples with a benchtop, field portable X-ray fluorescence (pXRF) spectrometer: evaluation of performance and potential applications for exploration lithogeochemistry. Geochemistry: Exploration, Environment, Analysis 14(2): 139-148.

Pollock, M., B.R. Edwards, S. Hauksdóttir, R. Alcorn, L. Bowman, 2014. Geochemical and lithostratigraphic constraints on the formation of pillow-dominated tindars from Undirhlíðar quarry, Reykjanes Peninsula, Southwest Iceland, Lithos 200: 317-333.

Ryan, P. C., D.P. West, K. Hattori, S. Studwell, D.N. Allen, J. Kim, 2015. The Influence of Metamorphic Grade on Arsenic in Metasedimentary Bedrock Aquifers: A Case Study from Western New England, USA. Sci. Total Environ. 505: 1320 - 330.

Raychowdhury, N., A. Mukherjee, P. Bhattacharya, K. Johannesson, J. Bundschuh, G.B. Sifuentes, A. del Rosario Storniolo, 2014. Provenance and fate of arsenic and other solutes in the Chaco-Pampean Plain of the Andean foreland, Argentina. J. of Hydrol. 518: 
300-316.

Ridley, W. I., 2012. Petrology of Associated Igneous Rocks. In: Volcanogenic massive sulfide occurrence model: U.S. Geological Survey Scientific Investigations Report 2010-5070C, pp. $227-262$.

Rollinson, H., 1993. Using geochemical data: evaluation, presentation, and interpretation. Harlow, Longman Scientific and Technical.

Rudnick , R.L., S. Gao. 2003. 3.01- Composition of the Continental Crust Holland. In: H. D., K.K. Turekian (Eds.) Treatsie on Geochemistry. Oxford, Pergamon, pp. 1-64.

Ryan, J.G., J.D. Morris, T. Tera, W.P. Leeman, A. Tsvetkof, 1995. The slab effect as a function of depth: Evidence from across-arc geochemical variations in the Kurile arc. Science 270: $625-627$.

Ryan, P. C., D.P. West, K. Hattori, S. Studwell, D.N. Allen, J. Kim, 2015. The Influence of Metamorphic Grade on Arsenic in Metasedimentary Bedrock Aquifers: A Case Study from Western New England, USA. Sci. Total Environ. 505: 1320 - 330.

Schulz, K.J. 2012. Regional Environment. In: Volcanogenic massive sulfide occurrence model: U.S. Geological Survey Scientific Investigations Report 2010-5070-C, pp. 35-60.

Shanks III, W.C., R. Koski, 2012. Introduction. In: Volcanogenic massive sulfide occurrence model: U.S. Geological Survey Scientific Investigations Report 2010-5070-C, pp. 5 -8.

Shanks III, W.C., 2012. Hydrothermal Alteration. In: Volcanogenic massive sulfide occurrence model: U.S. Geological Survey Scientific Investigations Report 2010-5070 -C, pp. 167 180.

Smedley, P.L., D.G. Kinniburgh, 2001. A review of the source, behaviour and distribution of arsenic in natural waters. Appl. Geochem. 17: 517-668.

Stanton, R.L., 1994. Ore elements in arc lavas. Oxford Monographs on Geology and Geophysics 29 (391 pp.).

Stewart, R.M. 1963. Mines and mineral resources of San Diego County, California. California Division of Mines and Geology County Report 3, pp. 49-50.

Webster, J.G., 1999. Arsenic. In: Marshall, C.P., Fairbridge, R.W. (Eds.), Encyclopedia of Geochemistry. Chapman Hall, London, pp. 21-22.

Winkel, L., M. Berg, M. Amini, S.J. Hug, A. Johnston, 2008. Predicting groundwater arsenic contamination in Southeast Asia from surface parameters. Nat. Geosci. 1: 536-542. 
CHAPTER 3: Arsenic Mineral Associations in the Black Mountain SPV Ore Deposit

\subsection{Introduction}

Minerals that host arsenic provide insight into arsenic (As) geochemical cycling, since As is present in over 560 chemically diverse minerals that form under a wide range of geochemical conditions (Majzlan et al. 2014). While As is not recognized as a significant component of major rock forming minerals (e.g. silicates and carbonates), it can easily take the place of sulfur in the abundant primary mineral, pyrite $\left(\mathrm{FeS}_{2}\right)($ Smedley and Kinniburgh 2001, Drahota and Filippi 2009, Majzlan et al. 2014). When such primary As minerals are exposed to air and/or aerated water, alteration reactions form secondary minerals enriched in $\mathrm{As}$, like scorodite $\left(\mathrm{FeAsO}_{4} \cdot\right.$ $2 \mathrm{H}_{2} 0$ ). Thus, As may be mobilized from both primary and secondary minerals during modern water-rock interactions, since it is soluble over a wide $\mathrm{pH}$ range and in both oxidizing and reducing conditions (Smedley and Kinniburgh 2001).

By examining primary and secondary As host minerals and their associated As concentrations, we aim to enhance our understanding of As geochemical cycling in Black Mountain SPV, especially during modern water-rock interactions. Such knowledge will inform future research on As transport from Black Mountain SPV, and provide insight into the potential for As to mobilize from host rocks into surrounding communities. 


\subsection{Study area}

Black Mountain Open Space Park is located the Rancho Peñasquitos community of northern San Diego in Southern California (CA), USA (Fig 3.1a). The park contains $>15 \mathrm{~km}$ of hiking and biking trails climbing to $\sim 500 \mathrm{~m}$ and is composed of chaparral, chaparral-coastal sage scrub, and coastal sage scrub vegetation. Surface water within the park drains into channels that eventually empty into the San Dieguito River. However, rainfall is limited $(<30 \mathrm{~cm} / \mathrm{yr})$ in this semi-arid region of the Southwestern USA.

Field mapping for this study produced a preliminary, 1: 30,000 geologic map (Fig 2.1b) for a portion of the Black Mountain SPV, where As may be enriched along a $\sim \mathrm{N} 15^{\circ} \mathrm{W}-\mathrm{N} 20^{\circ} \mathrm{W}$ striking fracture zone, since extrapolation of this fracture zone along strike beyond the study area led to the discovery of an artisanal strip mine approximately two miles north of the park (Fig 3.1b). Though portions of Black Mountain Open Space Park were mined for As in the 1920s (Stewart 1963), no previous work has attempted to characterize As host minerals in Black Mountain SPV. Because there are no reports of As enrichment elsewhere in the SPV, we will hereafter call As-enriched SPV cropping out at Black Mountain Open Space Park the Black Mountain SPV ore deposit. 


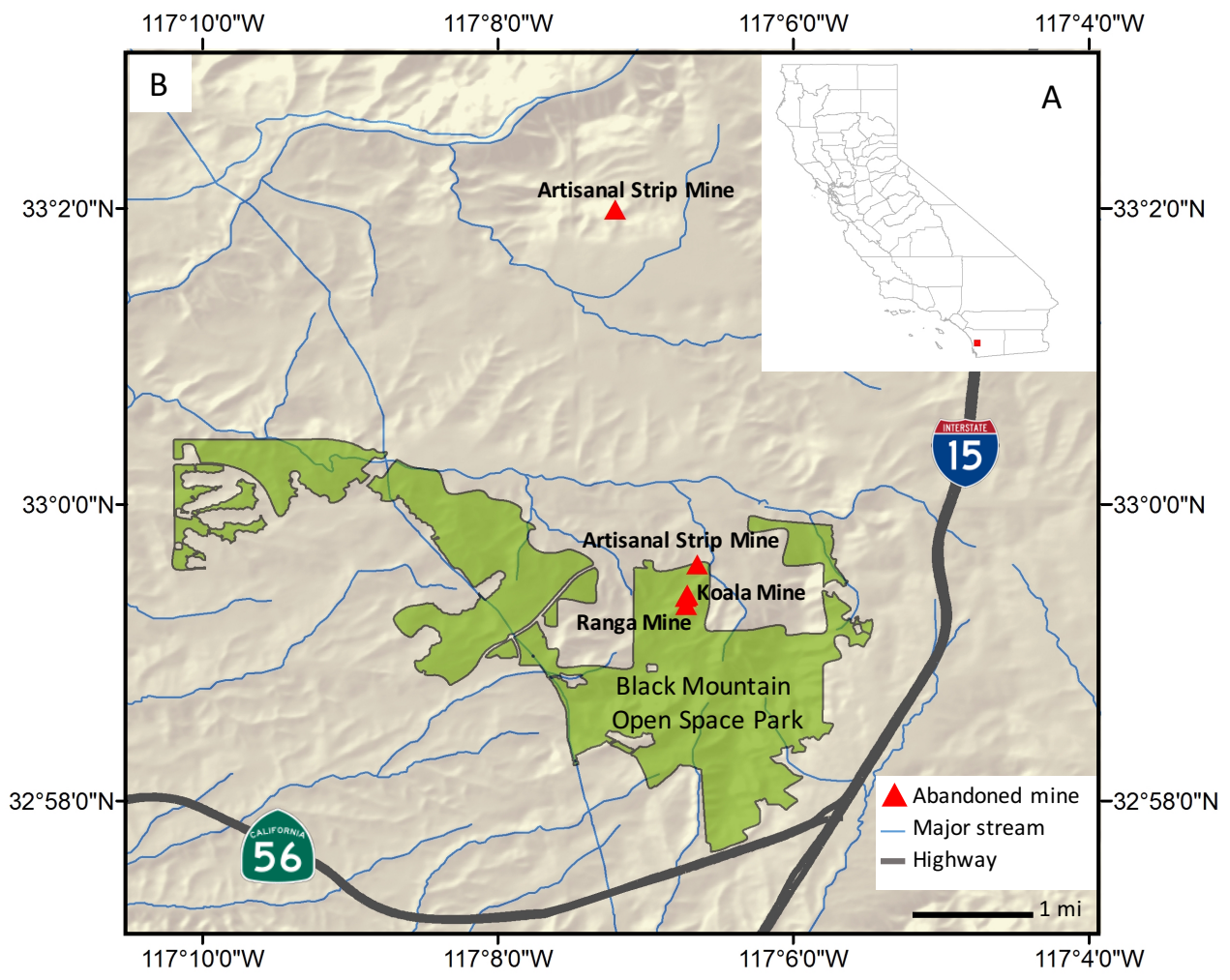

Fig 3.1: A) Location of study area within State of California, USA. B) Location of Black Mountain Open Space Park, San Diego, CA. The park boundary is highlighted in green, and red triangles give locations of abandoned As mines. 


\subsection{Methods}

\subsubsection{Sample collection}

Extent of As enrichment in Black Mountain SPV was initially evaluated by field-portable Xray fluorescence (FP-XRF, Haffert \& Craw 2009) (Fig 3.2), allowing us to collect in-situ and waste-rock samples $(n=67)$ with a wide range of As concentrations. The majority of samples ( $n$ =59) were collected from the northern portion of Black Mountain Open Space Park surrounding abandoned As mines, and the remaining samples $(n=8)$ were collected from the artisanal strip mine to the north of the park (Fig 3.1b).

\subsubsection{Bulk rock preparation}

Bulk rock samples $(n=67)$ were pulverized into a fine powder using a Bico Pulverizer fitted with ceramic plates at the University of San Diego (USD). All equipment was routinely cleaned with acetone and compressed air to avoid cross contamination between samples.

\subsubsection{Sub-sample preparation}

Because many samples were highly heterogeneous, sometimes showing weathering rinds, metamorphic alteration assemblages, veins, and volcaniclastics on very small $(\mathrm{mm})$ spatial scales, we used a diamond-tipped Dremel tool to target subareas of whole rock samples. The term "sub-sample" is hereafter used to define Dremel-targeted samples.

\subsubsection{Arsenic concentration}

Powdered rocks and sub-samples $(\mathrm{n}=168)$ were analyzed for trace metals by an Innov$\mathrm{X}-5000 \mathrm{X}$-ray Fluorescence (XRF) at USD. The quality assurance/quality control (QA/QC) procedures for samples with $<1,000 \mathrm{ppm}$ As are presented in Chapter 2 of this thesis under section 2.3.5. Because we detected anomalous As concentrations (>1,000 ppm) in $22 \%$ of samples and sub-samples $(\mathrm{n}=37)$ of Black Mountain SPV, we conducted additional QA/QC 
procedures to evaluate the accuracy of such anomalous concentrations. Three representative ultra-enriched samples were selected for analysis by EPA 6000/7000 series methods, and resulting As concentrations were compared to As content reported by the XRF. Compared to the EPA 6000/7000 series methods, the Innov-X-5000 XRF either reported anomalous As content accurately ( $<5 \%$ difference) or under-reported As by up to $24 \%$ (Table 3.1). While there are several possible reasons for this discrepancy in accuracy (e.g., analytical differences, sample heterogeneity) the purpose of analyzing these samples externally was to confirm the order of magnitude concentration of As being detected at Black Mountain since the As concentrations here are so anomalously enriched.

\subsubsection{Mineralogical analysis}

Powdered bulk rocks and sub-samples $(\mathrm{n}=168)$ were analyzed by PANalytical X'Pert PRO X-ray diffraction (XRD) at San Diego State University (SDSU). The XRD used a copper K $\alpha$ Xray source and operated at $45 \mathrm{kV}$ and $40 \mathrm{~mA}$. Mineral identification and pattern manipulation were conducted using X'Pert Data Software Suite and the Joint Committee on Powder Diffraction Standards (JCPDS) reference database. Identified minerals were assigned a score from $0-100$ by HighScore PANalytical Software, where 100 is a perfect match with X-ray spectra from the JCPDS reference database. 
Table 3.1: QA/QC for samples with anomalous As concentrations

\begin{tabular}{|r|c|c|c|}
\hline Sample ID & As (ppm) USD $^{\mathbf{1}}$ & ${\text { As (ppm) } \text { EPA }^{\mathbf{2}}}^{\text {\% }}$ Difference $^{\mathbf{3}}$ \\
\hline R022i & 131,687 & 158,000 & $-17 \%$ \\
\hline Mr002 & 167,070 & 165,000 & $1 \%$ \\
\hline Mk004 & 297,156 & 390,000 & $-24 \%$ \\
\hline
\end{tabular}

1: Arsenic concentration measured by Innov-X-5000 XRF at the University of San Diego (USD)

2: Arsenic content measured by EPA $6000 / 7000$ series methods at

EnviroMatrix Analytical, Inc.

$3: \%$ difference $=100 *(($ As EPA - As USD $) /$ As USD $)$ 


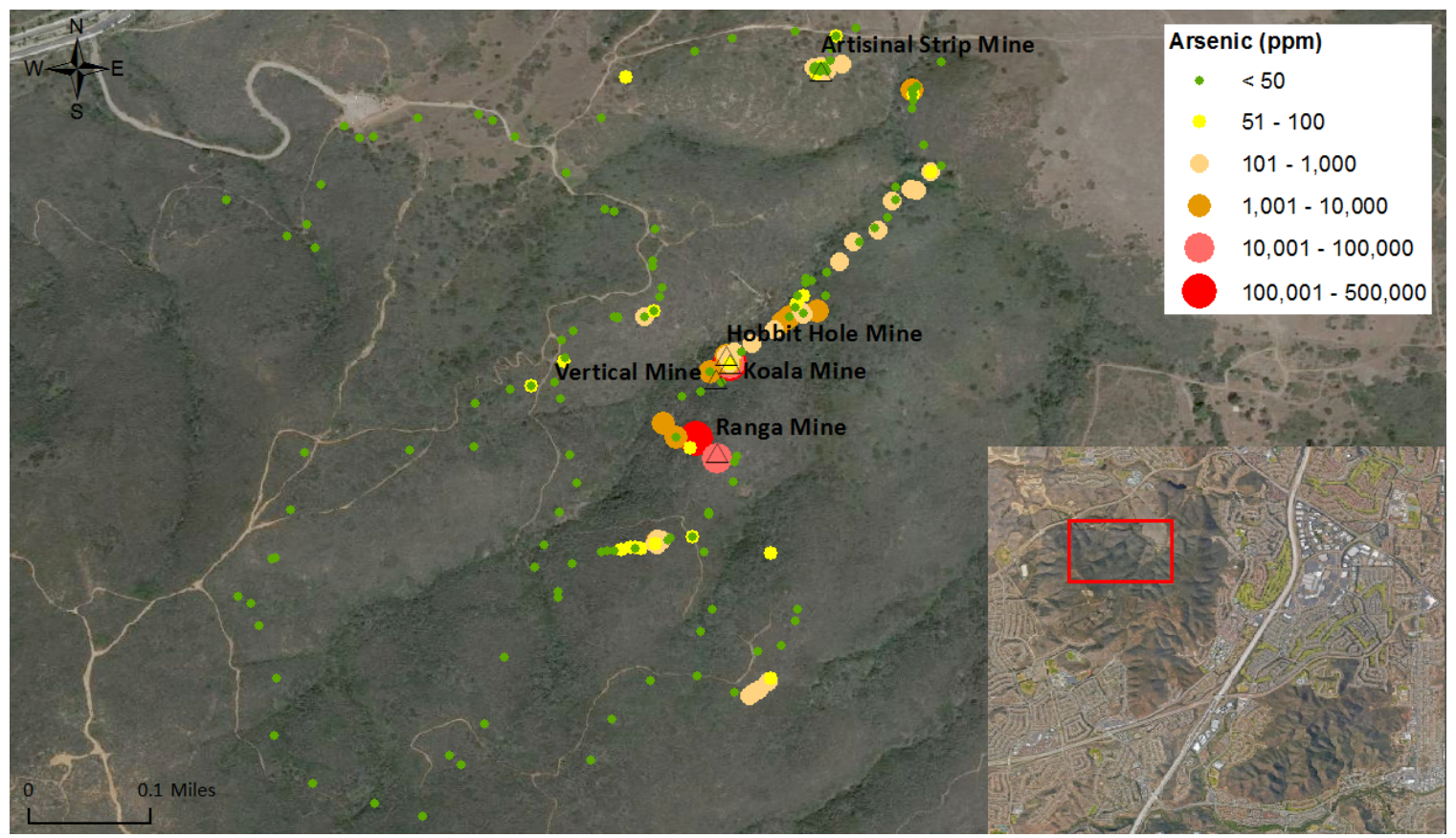

Fig 3.2: Distribution of As in rocks and soil in a portion of Black Mountain Open Space Park. Preliminary As concentrations measured by FP-XRF (after Haffert \& Craw 2009) 


\subsection{Results}

\subsubsection{Arsenic enrichment}

The total As concentration of powdered bulk rock and sub-samples $(\mathrm{n}=168)$ ranged from non-detectable $(<2 \mathrm{ppm})$ to nearly $300,000 \mathrm{ppm}\left(\right.$ mean $\left.=7,476 \pm 2,694^{2} \mathrm{ppm} \mathrm{As}\right)$. We found that As was most enriched in samples collected from abandoned As mines $(n=27$, mean $=36,745 \pm$

13,801 ppm As), and samples and sub-samples of waste rocks were also highly enriched in As (n $=12$, mean $=3,051 \pm 2,259 \mathrm{ppm}$ As). Subsamples of weathering rinds and veins typically contained greater As concentrations $(n=44$, mean $=9,475 \pm 4,941$ ppm As $)$ than subsamples of fresh rock $(\mathrm{n}=44$, mean $=538 \pm 245$ ppm As $)($ Table 3.2) .

${ }^{2}$ Standard error $=\frac{\text { Standard deviation }(\sigma)}{\sqrt{\text { Sample size }(\mathrm{n})}}$ 
Table 3.2: Trace metal concentrations in Black Mountain SPV. Average +/- standard error. Geochemical techniques presented in Chapter 2 allowed lithologic confirmation of rocks described here as 'bulk rhyolites' and 'bulk dacites', which permitted them to be confidently presented separately from other sub-samples analyzed as part of this chapter.

\begin{tabular}{rccccc}
\hline & As $(\mathrm{ppm})$ & $\mathrm{Cu}(\mathrm{ppm})$ & $\mathrm{Pb}(\mathrm{ppm})$ & Sb $(\mathrm{ppm})$ & $\mathrm{Zn}(\mathrm{ppm})$ \\
\hline All samples \& sub-samples $(\mathrm{n}=168)$ & $7,476+/-2,694$ & $105+/-17$ & $79+/-12$ & $58+/-4$ & $139+/-16$ \\
Bulk rhyolites $(\mathrm{n}=10)$ & $586+/-10$ & $30+/-6$ & $28+/-4$ & $4+/-3$ & $46+/-8$ \\
Bulk dacites $(\mathrm{n}=10)$ & $14+/-9$ & $30+/-3$ & $12+/-2$ & $\mathrm{ND}$ & $114+/-13$ \\
Mine samples \& sub-samples $(\mathrm{n}=27)$ & $36,745+/-13,801$ & $335+/-76$ & $95+/-22$ & $66+/-12$ & $121+/-29$ \\
Waste rock samples \& sub-samples $(\mathrm{n}=12)$ & $3,051+/-2,259$ & $56+/-19$ & $125+/-44$ & $48+/-15$ & $191+/-57$ \\
Fresh sub-samples $(\mathrm{n}=44)$ & $538+/-245$ & $57+/-9$ & $38+/-5$ & $75+/-7$ & $128+/-22$ \\
Weathered sub-samples $(\mathrm{n}=44)$ & $9,475+/-4,941$ & $112+/-22$ & $110+/-25$ & $68+/-8$ & $140+/-15$ \\
Average in upper-crust* & 4.8 & 28 & 17 & 0.4 & 47 \\
\hline
\end{tabular}

*: Rudnick and Gao (2003) 


\subsubsection{Arsenic mineral associations}

\subsubsection{Field observations}

We observed evidence for several phases of primary and secondary As host minerals in Black Mountain SPV. First, field observation of areas where FP - XRF detected anomalous As $(>1,000 \mathrm{ppm})$ revealed that As-rich outcrops characteristically exhibited bright colors of purplered, maroon, orange, yellow, and grey veins varying in thickness from $\mathrm{cm}$ to massive, metersized areas of alteration. These outcrops had typically been disturbed into meter-scale pits and cave-like mines.

\subsubsection{Mineral Identification by Powder X-ray diffraction}

Targeted Dremel sampling (Fig 3.3d) and XRF analysis of each distinctively colored vein or crystal mass revealed As concentrations ranging from $923 \mathrm{ppm}$ to 297,156 ppm. We then identified potential As host minerals using XRD. We found evidence of arsenopyrite (FeAsS, Fig 3.4a) in a powder containing 297,156 ppm As (Fig 3.3a). We identified natrojarosite (Fig 3.4b) in a powder containing 49,660 ppm As (Fig 3.3b), and pyrite $\left(\mathrm{FeS}_{2}\right)$ and scorodite $\left(\mathrm{FeAsO}_{4} \cdot\right.$ $2 \mathrm{H}_{2} 0$ ) (Fig 3.4c) were detected in a powder containing 110,100 ppm As (Fig 3.3c). In a powder with 167,070 ppm As, we identified natropharmacosiderite $\left[(\mathrm{Na}, \mathrm{K}) \mathrm{Fe}_{4}{ }^{3+}\left(\mathrm{AsO}_{4}\right)_{3}(\mathrm{OH})_{4} \bullet 6-\right.$ $\left.7 \mathrm{H}_{2} \mathrm{O}\right]$, arsenosiderite $\left(\mathrm{Ca}_{2} \mathrm{Fe}^{3+} \mathrm{O}_{2}\left(\mathrm{AsO}_{4}\right)_{3} \bullet 3 \mathrm{H}_{2} \mathrm{O}\right)$, and yukonite $\left(\mathrm{Ca}_{7} \mathrm{Fe}^{3+}\left(\mathrm{AsO}_{4}\right)_{10}(\mathrm{OH})_{20} \bullet\right.$ $\left.15 \mathrm{H}_{2} \mathrm{O}\right)$ (Fig 3.4d). We detected schauertite $\left(\mathrm{Ca}_{3} \mathrm{Ge}\left(\mathrm{SO}_{4}\right)_{2}(\mathrm{OH})_{6} \cdot 3 \mathrm{H}_{2} \mathrm{O}\right)$ in a powder containing 8,507 ppm As. Finally, we identified gypsum $\left(\mathrm{CaSO}_{4} \cdot 2 \mathrm{H}_{2} \mathrm{O}\right)(\mathrm{Fig} 3.4 \mathrm{f})$ in a powder containing 923 ppm As (Fig 3.3f). The XRD detected goethite in 17 powders. Analysis by XRF indicates that such powders contain 4,402 $\pm 2,516$ ppm As (Table 3.3). 


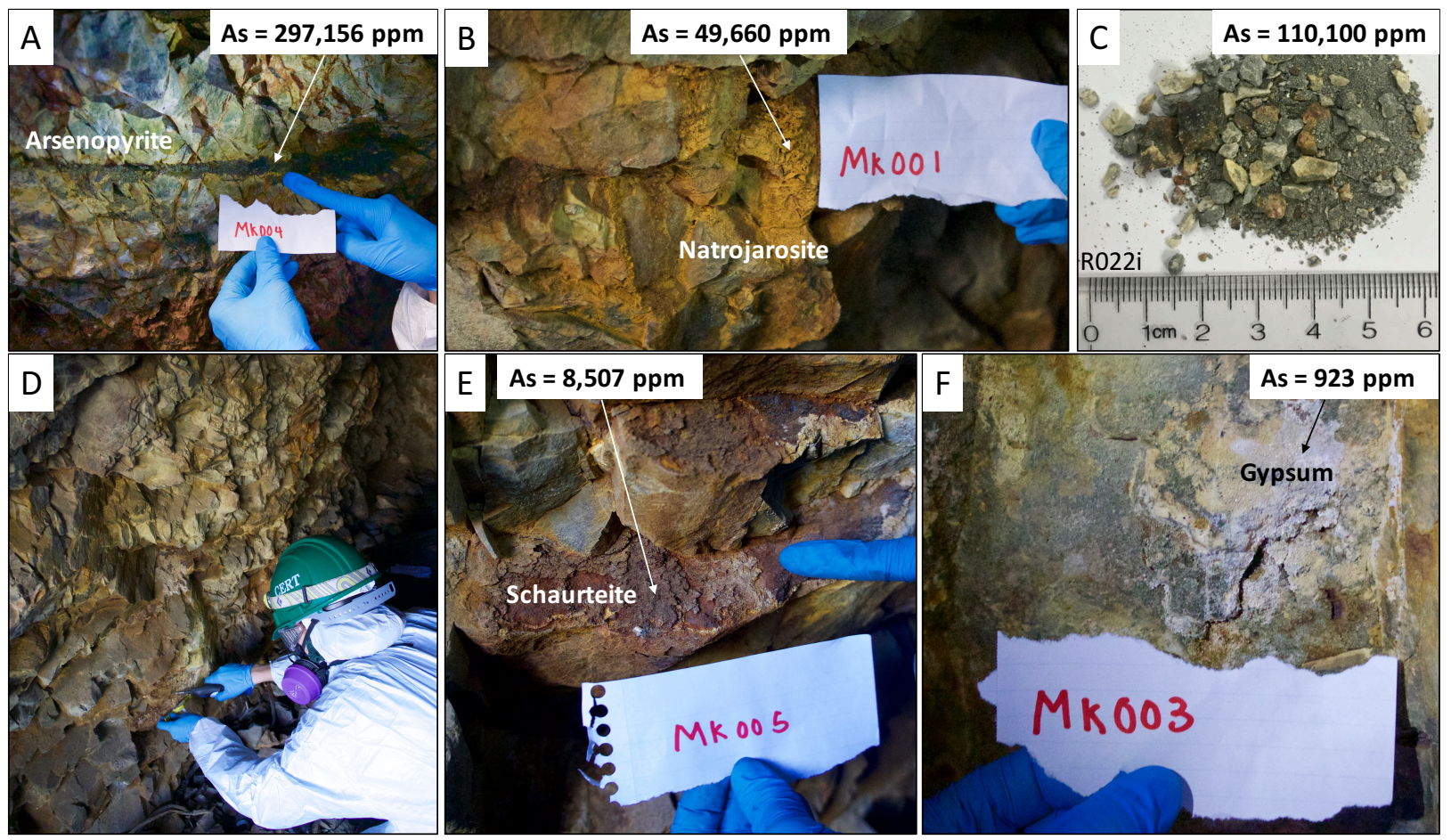

Fig 3.3: Photographs showing: a) Field observations of an arsenopyrite vein, b) Field observations of natrojarosite, c) Sample of scorodite and pyrite in laboratory, d) Method for Dremel-targeted sampling, e) Field observations of schauertite, and f) Field observations of gypsum. 

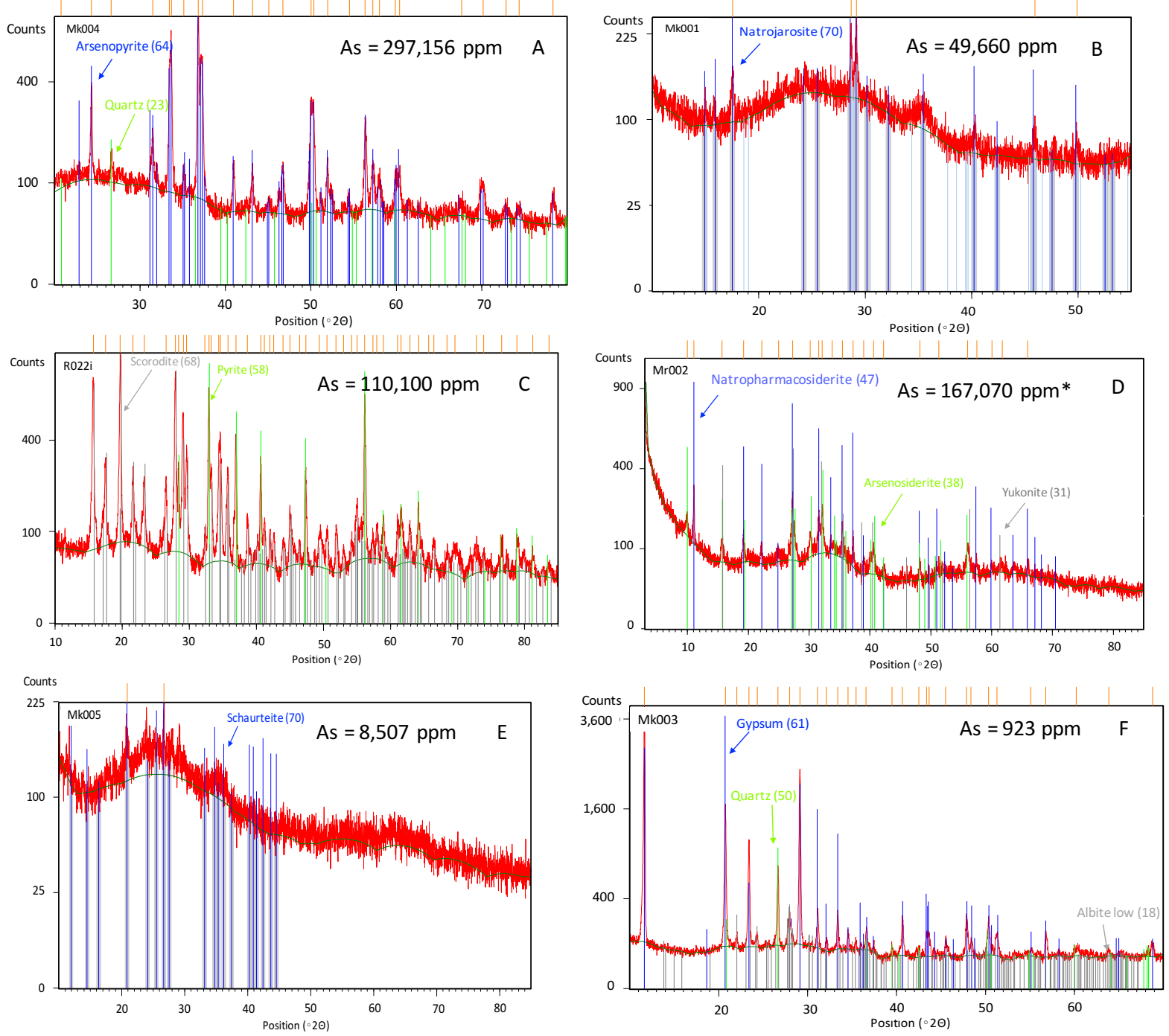

Fig 3.4: XRD spectra for samples: a) Mk004, b) Mk001, c) R022i, d) Mr002, e) Mk005, and f) Mk003. Values to right of identified mineral names represents a score assigned by X'Pert Data Software Suite. The score ranges from 0 - 100, with 100 being a perfect match with X-ray spectra from JCPDS Reference Database. 
Table 3.3: Trace metal content of powered bulk rock samples and subsamples containing goethite

\begin{tabular}{|c|c|c|c|c|c|c|}
\hline Sample ID & As (ppm) & $\mathrm{Cu}$ (ppm) & $\mathrm{Pb}$ (ppm) & Zn (ppm) & Minerals detected by XRD & Score* \\
\hline \multirow[t]{2}{*}{ R002wp_w } & 663 & 367 & $<L O D$ & 156 & Quartz & 61 \\
\hline & & & & & Goethite & 43 \\
\hline \multirow[t]{4}{*}{ R003wp } & 267 & 123 & 17 & 62 & Quartz & 66 \\
\hline & & & & & Albite low & 47 \\
\hline & & & & & Magnetite & 36 \\
\hline & & & & & Goethite & 22 \\
\hline \multirow[t]{2}{*}{ R003wp_w } & 958 & 484 & 565 & 304 & Quartz & 70 \\
\hline & & & & & Goethite & 30 \\
\hline \multirow[t]{2}{*}{ R004i_w } & 598 & 510 & 644 & 100 & Quartz & 52 \\
\hline & & & & & Goethite & 45 \\
\hline \multirow[t]{2}{*}{ R005wp_w } & 1523 & 320 & $<L O D$ & 163 & Quartz & 64 \\
\hline & & & & & Goethite & 45 \\
\hline \multirow[t]{4}{*}{ R008f } & 2787 & 66 & 50 & 197 & Quartz & 48 \\
\hline & & & & & Goethite & 36 \\
\hline & & & & & Rutile & 29 \\
\hline & & & & & Hematite & 20 \\
\hline \multirow[t]{3}{*}{ R008f_w } & 6658 & $<L O D$ & $<$ LOD & 377 & Quartz & 62 \\
\hline & & & & & Hematite & 40 \\
\hline & & & & & Goethite & 15 \\
\hline \multirow[t]{3}{*}{ R010f } & 806 & 42 & 508 & 37 & Hematite & 67 \\
\hline & & & & & Quartz & 43 \\
\hline & & & & & Goethite & 34 \\
\hline \multirow[t]{3}{*}{ R010f_w } & 659 & $<L O D$ & 629 & 26 & Hematite & 76 \\
\hline & & & & & Quartz & 38 \\
\hline & & & & & Goethite & 21 \\
\hline$R 015 f$ & $\angle L O D$ & 62 & 1007 & 276 & Goethite & 77 \\
\hline R015f_w & 85 & 35 & $<L O D$ & 135 & Goethite & 69 \\
\hline \multirow[t]{3}{*}{ R017f_w2 } & 575 & 84 & $<L O D$ & 146 & Quartz & 69 \\
\hline & & & & & Hematite & 30 \\
\hline & & & & & Goethite & 25 \\
\hline \multirow[t]{2}{*}{ R017f_w3 } & 327 & 120 & 348 & 126 & Goethite & 50 \\
\hline & & & & & Baumite & 30 \\
\hline \multirow[t]{3}{*}{ R018f_w } & 113 & 84 & 40 & 120 & Goethite & 69 \\
\hline & & & & & Hematite & 53 \\
\hline & & & & & Quartz & 41 \\
\hline \multirow[t]{3}{*}{ R018f_w2 } & 185 & 98 & 203 & 163 & Quartz & 71 \\
\hline & & & & & Goethite & 49 \\
\hline & & & & & Hematite & 44 \\
\hline \multirow[t]{4}{*}{ R024wp_w } & 5274 & 199 & 304 & 124 & Hematite & 61 \\
\hline & & & & & Quartz & 50 \\
\hline & & & & & Albite low & 28 \\
\hline & & & & & Goethite & 22 \\
\hline \multirow[t]{3}{*}{ R043wp_w } & 43147 & 163 & 437 & 168 & Quartz & 65 \\
\hline & & & & & Kusachiite & 21 \\
\hline & & & & & Goethite & 20 \\
\hline \multirow[t]{3}{*}{ R044i_w } & 10205 & 323 & $<$ LOD & 336 & Goethite & 38 \\
\hline & & & & & Quartz & 27 \\
\hline & & & & & Albite, Ca-rich, ordered & 16 \\
\hline Average & $4,402 \pm 2,516$ & $193 \pm 38$ & $396 \pm 72$ & $168 \pm 24$ & & \\
\hline Min & 85 & 35 & 17 & 26 & & \\
\hline Max & 43,147 & 510 & 1,007 & 377 & & \\
\hline
\end{tabular}

*Values represent a score from $0-100$, with 100 being a perfect match with X-ray spectra from JCPDS Reference Database 


\subsection{Discussion}

\subsubsection{Arsenic enrichment in Black Mountain SPV Ore Deposit}

Unlike other trace metals detected by XRF (e.g. $\mathrm{Pb}, \mathrm{Cu}, \mathrm{Sb}, \mathrm{Zn}$ ), we found that As was consistently anomalously enriched (>1000 ppm) in the Black Mountain SPV ore deposit (Table 3.2). We detected As concentrations up to almost 300,000 ppm in samples and subsamples ( $\mathrm{n}=$ 168) of Black Mountain SPV. Approximately 93\% of samples $(n=168)$ exceed the average As concentration for the upper crust (4.8 ppm As, Rudnick and Gao 2003), and 94\% exceed the average As concentration for igneous rocks (1.5 ppm As, Smedley and Kinniburgh 2001). Within the Black Mountain SPV ore deposit, As was often present in weathering rinds, veins, and/or along fractures.

\subsubsection{Arsenic in fresh versus weathered rock}

Subsampling of rocks with coherent weathering rinds and/or veins $(n=44)$ allowed us to compare As content in the weathered components to the As content of the fresh component of the same rock. We found that for $95.5 \%$ of such samples, the weathered portion contained more As (Fig 3.5). Further, subsamples of weathering rinds and veins typically contained greater As concentrations on average $(n=44$, mean $=9,475 \pm 4,941$ ppm As $)$ than subsamples of fresh rock $(\mathrm{n}=44$, mean $=538 \pm 245 \mathrm{ppm}$ As) (Table 3.2). This finding indicates that As in Black Mountain SPV is re-dispersed into secondary host minerals during modern water-rock interactions.

\subsubsection{Arsenic host minerals}

We observed evidence for several phases of primary and secondary As host minerals, including primary minerals arsenopyrite $(\mathrm{FeAsS})$ and pyrite $\left(\mathrm{FeS}_{2}\right)$, which can incorporate up to 46\% and 10\% As (Kolker and Nordstrom 2001), respectively. Primary minerals in Black 
Mountain SPV were likely altered to form several phases of secondary host minerals. In in-situ Black Mountain SPV disturbed by mining, we observed evidence for As in known secondary host minerals, like scorodite $\left(\mathrm{FeAsO}_{4} \cdot \mathrm{H}_{2} 0\right)$, natropharmacosiderite $\left[(\mathrm{Na}, \mathrm{K}) \mathrm{Fe}_{4}{ }^{3+}\left(\mathrm{AsO}_{4}\right)_{3}(\mathrm{OH})_{4} \bullet\right.$ 6-7 $\left.\mathrm{H}_{2} \mathrm{O}\right]$, arseniosiderite $\left(\mathrm{Ca}_{2} \mathrm{Fe}^{3+} \mathrm{O}_{2}\left(\mathrm{AsO}_{4}\right)_{3} \bullet 3 \mathrm{H}_{2} \mathrm{O}\right)$, and yukonite $\left(\mathrm{Ca}_{7} \mathrm{Fe}^{3+}\left(\mathrm{AsO}_{4}\right)_{10}(\mathrm{OH})_{20} \bullet\right.$ $\left.15 \mathrm{H}_{2} \mathrm{O}\right)$.

\subsubsection{Arsenopyrite weathering}

Though scorodite is one common weathering product of arsenopyrite (Eq. 3.1, Foster et al. 1998, Savage et al. 2000, Asta et al. 2009), arsenopyrite may also weather to hydrous ferric oxides (HFO) (Eq 3.2, Majzlan et al. 2014). Subsequently, HFOs age, remobilize, and crystallize to eventually form minerals of the pharmacosiderite supergroup (Eq 3.3, Haffert et al. 2010), like natropharmacosiderite and arseniosiderite. Yukonite is relatively rare, but is often found in association with minerals of the pharmacosiderite supergroup (Majzlan et al. 2014). Minerals of this group eventually weather to become goethite (Eq 3.4, Eq 3.5, Majzlan et al. 2014). Thus, As-rich goethite is a likely end-product of the Black Mountain SPVAs mineral weathering system.

Eq 3.1: $\mathrm{FeAsS}+3 \mathrm{H}_{2} \mathrm{O}+3.5 \mathrm{O}_{2} \rightarrow \mathrm{FeAsO}_{4} \cdot 2 \mathrm{H}_{2} \mathrm{O}+\mathrm{SO}_{4}{ }^{2-}+2 \mathrm{H}^{+}$

Arsenopyrite Scorodite

Eq 3.2: $\mathrm{FeAsS}+3 \mathrm{H}_{2} \mathrm{O}+3.5 \mathrm{O}_{2} \rightarrow \mathrm{FeOOH}+\mathrm{H}_{2} \mathrm{AsO}_{4}{ }^{-}+\mathrm{SO}_{4}{ }^{2-}+3 \mathrm{H}^{+}$ Arsenopyrite HFO

Eq 3.3: $4 \mathrm{FeOOH}+3 \mathrm{H}_{2} \mathrm{AsO}_{4}{ }^{-}+0.5 \mathrm{Ba}^{2+}+\mathrm{H}_{2} \mathrm{O}+2 \mathrm{H}^{+} \rightarrow \mathrm{Ba}_{0.5} \mathrm{Fe}_{4}(\mathrm{OH})_{4}\left(\mathrm{AsO}_{4}\right)_{3} \cdot 5 \mathrm{H}_{2} \mathrm{O}$ HFO Bariopharmacosiderite

Eq 3.4: $4 \mathrm{Ba}_{0.5} \mathrm{Fe}_{4}\left(\mathrm{AsO}_{4}\right)_{3}(\mathrm{OH})_{5} \cdot 5 \mathrm{H}_{2} \mathrm{O}+9 \mathrm{Ca}^{2+} \rightarrow 3 \mathrm{Ca}_{3} \mathrm{Fe}_{4}(\mathrm{OH})_{6}\left(\mathrm{AsO}_{4}\right) 4 \cdot 3 \mathrm{H}_{2} \mathrm{O}+4 \mathrm{Fe}(\mathrm{OH})_{3}{ }^{0}+2 \mathrm{Ba}^{2+}+14 \mathrm{H}^{+}$ Bariopharmacosiderite Arseniosiderite

Eq 3.5: $\mathrm{Ca}_{3} \mathrm{Fe}_{4}(\mathrm{OH})_{6}\left(\mathrm{AsO}_{4}\right)_{4} \cdot 3 \mathrm{H}_{2} \mathrm{O}+2 \mathrm{H}^{+} \rightarrow 4 \mathrm{FeOOH}(\mathrm{s})+3 \mathrm{Ca}^{2+}+4 \mathrm{H}_{2} \mathrm{AsO}_{4}^{-}+\mathrm{H}_{2} \mathrm{O}$ Arseniosiderite Goethite 
In Black Mountain SPV, we found that As content was highest in a powder containing arsenopyrite (297,156 ppm As), while a powder containing natropharmacosiderite, arsenosiderite, and yukonite contained 167,070 ppm As. Powders containing goethite and no other known As host minerals (other than hematite) contained As concentrations ranging from 85 ppm As to 43,147 ppm As ( $\mathrm{n}=17$, mean $=4,402 \pm 2,516 \mathrm{ppm}$ As). Thus, we found evidence for several stages of alteration and As remobilization, and that As content is lower in later-stage minerals (Fig 3.6).

\subsubsection{Sulfate replacement by arsenate}

We detected 49,660 ppm As in a powder containing natrojarosite. (Natro)jarosite $\left[(\mathrm{Na}) \mathrm{Fe}_{3}\left(\mathrm{SO}_{4}\right)_{2}(\mathrm{OH})_{6}\right]$ is an important constituent of mine wastes derived from arsenian pyrite. Previous studies (e.g. Savage et al. 2000, Asta et al. 2009) have demonstrated that arsenate $\left(\mathrm{AsO}_{4}\right)$ may replace sulfate $\left(\mathrm{SO}_{4}\right)$ within the crystalline matrix of jarosite. Other studies (e.g Foster et al. 1998, Myneni et al. 1997) demonstrate that $\mathrm{AsO}_{4}$ can also take the place of $\mathrm{SO}_{4}$ in other common secondary minerals, such as gypsum $\left(\mathrm{CaSO}_{4} \cdot 2 \mathrm{H}_{2} \mathrm{O}\right)$. Our findings of $923 \mathrm{ppm}$ As in a powder containing gypsum support this hypothesis. We also detected 8,507 ppm As in a powder containing the rare mineral schauertite $\left(\mathrm{Ca}_{3} \mathrm{Ge}\left(\mathrm{SO}_{4}\right)_{2}(\mathrm{OH})_{6} \cdot 3 \mathrm{H}_{2} \mathrm{O}\right)$, further supporting our hypothesis of $\mathrm{SO}_{4}$ replacement by $\mathrm{AsO}_{4}$. 


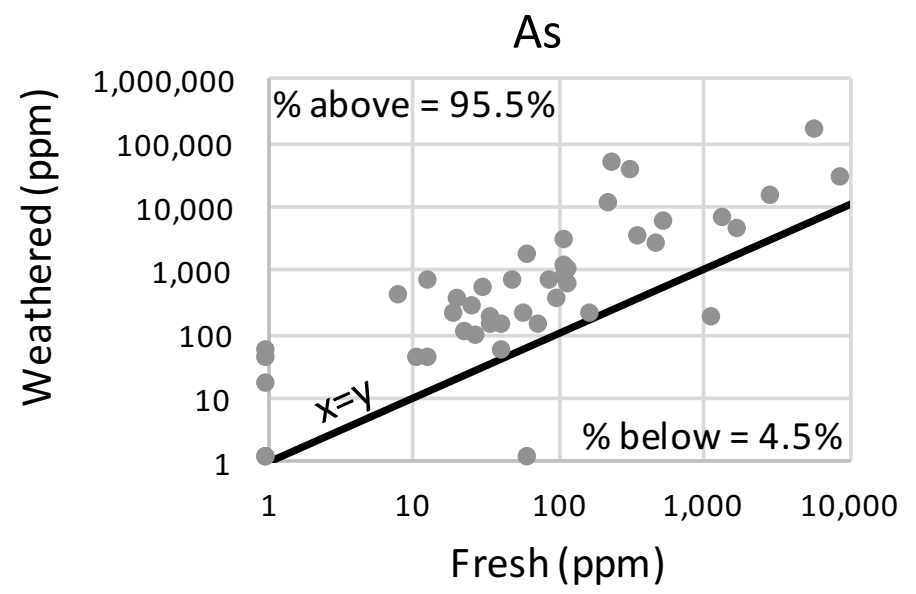

Fig 3.5: Arsenic in fresh versus weathered SPV subsamples. 


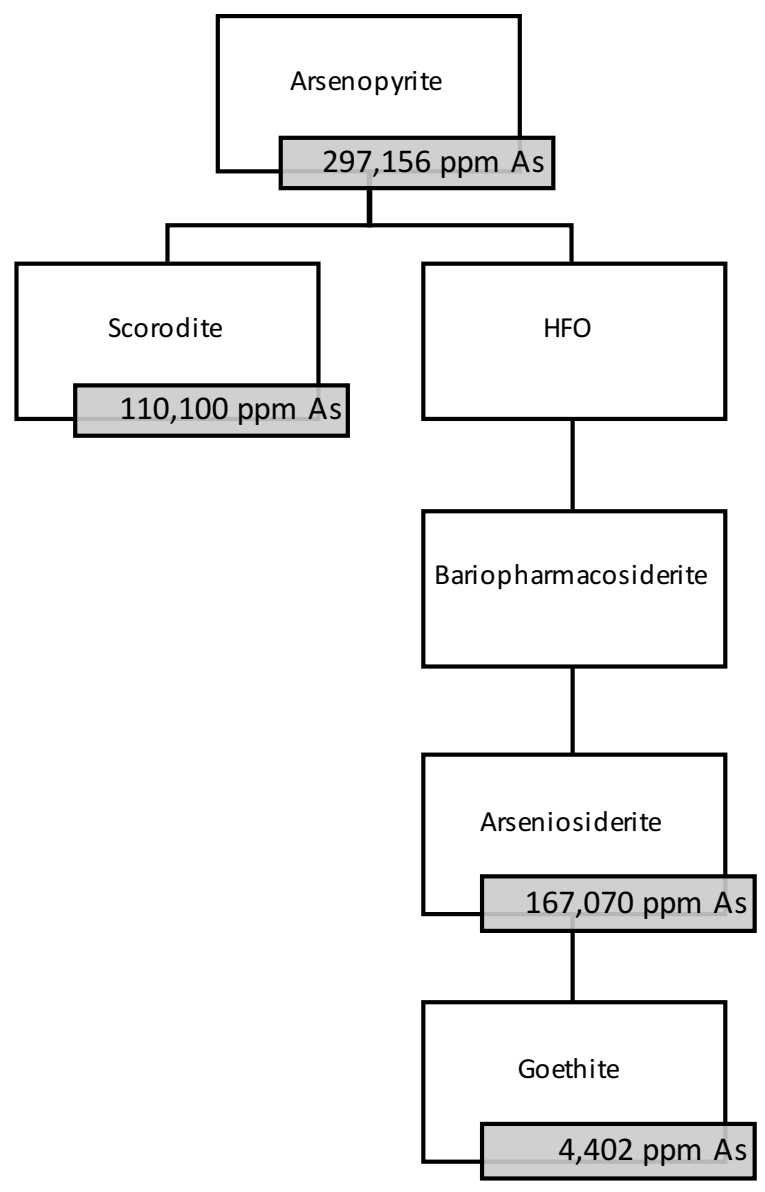

Fig 3.6: Schematic showing arsenopyrite weathering and associated As content of primary and secondary mineral phases. 


\subsection{Summary and conclusion}

We discovered As enrichment in Black Mountain SPV $(n=168)$ ranging from non-detect ( $<2$ ppm As) to nearly $300,000 \mathrm{ppm}$ As (mean $=7,476 \pm 2,694 \mathrm{ppm}$ As). This wide range in As content indicates that As is present in several primary and secondary host mineral phases, including those we've identified as arsenopyrite, scorodite, jarosite, iron oxides, and gypsum, among other host minerals presented in this paper. Our work also demonstrates that As content is likely highest in primary host minerals and decreases with each phase of primary mineral weathering (Fig 3.7). However, As content, even in late-stage secondary host minerals, is anomalous ( $>1,000 \mathrm{ppm}$ As). We detected greater As in weathering rinds and veins (mean $=$ $9,475 \pm 4,941 \mathrm{ppm})$ than the fresh components $($ mean $=538 \pm 245)$ of the same rock $(\mathrm{n}=44$, Fig 3.6), further indicating that As is mobilized during modern water-rock interactions. Our findings suggest the potential for As to be mobilized off-site during storm events, or via groundwater flow (assuming the ore deposit extends below the water table), and indicates a need for future research investigating As transport from host rocks. 


\subsection{Work cited}

Asta, M.P., J. Cama, M. Martinez, J. Gimenez, 2009. Arsenic removal by goethite and jarosite in acidic conditions and its environmental implications. J. of Haz. Mat. 171: 965-972.

Foster, A.L., G.E. Brown, Jr, T.N. Tingle, G.A. Parks, 1998. Quantitative arsenic speciation in mine tailings using X-ray absorption spectroscopy. Am. Min. 83: 553-568.

Haffert, L., D. Craw, 2009. Field quantification and characterization of extreme arsenic concentrations at a historic mine processing site, Waiuta, New Zealand. New Zealand Journal of Geology and Geophysics 52: 261-271.

Kolker, A., D. K. Nordstrom, 2001. Occurrence and microdistribution of arsenic in pyrite. In: Proceedings of the USGS Arsenic Workshop. US Geological Survey, Denver, pp. 3.

Majzlan, J., P. Drahota, M. Filippi, 2014. Parageneses and crystal chemistry of arsenic minerals. Reviews in Mineralogy and Geochemistry 79(1): 17-184.

Matera, V., I. Le Hecho, A. Laboudigue, P. Thomas, S. Tellier, M. Astruc, 2003. A methodological approach for the identification of arsenic bearing phases in polluted soils. Env. Poll. 126(1): 51-64.

Myneni, S.C.B., S.J. Traina, T.J. Logan, G.A. Waychunas, 1997. Oxyanion behaviour in alkaline environments: sorption and desorption of arsenate ettringite. Environ. Sci. Technol. 31: 1761-1768.

Rudnick, R.L., S. Gao., 2003. 3.01- Composition of the Continental Crust Holland. In: H. D., K.K. Turekian (Eds.) Treatise on Geochemistry. Oxford, Pergamon, pp. 1-64.

Savage, K.S., T.N. Tingle, P.A. O’Day, G.A. Waychunas, D.K. Bird, 2000. Arsenic speciation in pyrite and secondary weathering phases, Mother Lode Gold District, Tuolumne County, California. Appl. Geochem. 15: 1219-1244.

Smedley, P.L., D.G. Kinniburgh, 2001. A review of the source, behaviour and distribution of arsenic in natural waters. Appl. Geochem. 17: 517-668.

Stewart, R.M. 1963. Mines and mineral resources of San Diego County, California. California Division of Mines and Geology County Report 3, pp. 49-50. 
CHAPTER 4: Summary and Conclusion

\subsection{Summary}

1. What is the geology of rocks cropping out at Black Mountain Open Space Park, and over what spatial scale does rock type vary?

- The Santiago Peak Volcanics (SPV) outcropping at Black Mountain Open Space Park (i.e. Black Mountain SPV) are remnants of a subaerial volcanic arc that underwent syn-volcanic greenschist facies alteration

- Given the geochemical similarities between Black Mountain SPV and Northern Santa Ana Mountain SPV (Herzig and Kimbrough 2014), the two units likely evolved within the same volcanic arc system during the Cretaceous

- We observed welded tuffs, volcaniclastic (epiclastic) rocks, and accretionary lapilli in Black Mountain SPV, suggesting that several distinct stages of subaerial volcanic eruption occurred (Fig 2.2)

- Lavas ranged in composition from dacite to rhyolite (Fig 2.3)

- In areas of Black Mountain Open Space Park, rock type varies over the spatial scale of tens of meters (Fig 2.1)

2. What is the distribution of As among SPV rock types, and how can we use this knowledge to propose a model for As cycling in the ancient volcanic arc system?

- We found that As content varied between the two dominant SPV rock types, with rhyolites typically containing more As $(n=10$, mean $=586 \pm 10 \mathrm{ppm}$ As) than dacites $(\mathrm{n}=10$, mean $=14 \pm 9$ ppm As $)($ Table 2.2$)$ 
- Our findings of As enrichment in rhyolites, indicate that such enrichment may be controlled by the fractional crystallization of mafic magmas, with rocks crystallizing from more evolved melts containing greater As

- While highly soluble metals, As and $\mathrm{Pb}$, were more enriched in rhyolites, $\mathrm{Cu}$ was equally enriched in both rhyolites and dacites (Table 2.2).

- The high solubility of $\mathrm{As}$ and $\mathrm{Pb}$ likely caused these metals to be among the first released from subduction zone serpentinites during dehydration (Hattori and Guillot 2003), leading to their initial enrichment in partial melts underlying volcanic arc fronts

- Because of their incompatibility in these melts, $\mathrm{As}$ and $\mathrm{Pb}$ remained dissolved as melts evolved from mafic to felsic and, thus, were eventually exhumed in rhyolitic lavas

- Since $\mathrm{Cu}$ is not as soluble as $\mathrm{As}$ and $\mathrm{Pb}$ (Hack et al. 2006), $\mathrm{Cu}$ may have been released from serpentinites during later stages of subduction

- Based on our results and incorporating the findings of others, we propose a model to explain As enrichment in Black Mountain SPV (Fig 2.7)

3. What are the primary and secondary As host minerals in Black Mountain SPV, and how does knowledge of host minerals inform future research investigating As mobility?

- Primary host minerals likely include: pyrite and arsenopyrite (Fig 3.3, Fig 3.4)

- Secondary host minerals likely include: scorodite, jarosite, natropharmacosiderite, arseniosiderite, yukonite, iron oxides, and gypsum (Fig 3.3, Fig 3.4) 
- We found that As content is highest in primary host minerals and decreases with each phase of primary mineral weathering (Fig 3.6). However, As content, even in late-stage secondary host minerals, is anomalous $(>1,000$ ppm As)

- We detected greater As in weathering rinds and veins (mean =9,475 $\pm 4,941$ ppm) than the fresh components $($ mean $=538 \pm 245)$ of the same rock $(n=44$, Fig 3.5), indicating that As is mobilized during modern water-rock interactions

- Our findings of As enrichment in primary and secondary host minerals suggest the potential for As to be mobilized off-site during storm events, or via groundwater interaction, and indicate a need for future research investigating As transport from host rocks 


\subsection{Conclusion}

While the first two questions above contribute to growing knowledge of Black Mountain SPV and provenance of As in volcanic arc systems, the third question attempts to inform future research on As mobility at Black Mountain Open Space Park, given that As host minerals may exert an important and predictable control on As mobility in the natural environment (Smedley and Kinniburgh 2001). Based on the findings of this thesis, I recommend that future research conducted at Black Mountain Open Space Park address the following broad questions:

1. What is the spatial extent of geogenic As enrichment at Black Mountain Open Space Park, and what is the potential for human exposure to such As?

2. Is As being mobilized from host rocks, sediments, and soils during rain events, and does storm water transport As into communities surrounding Black Mountain Open Space Park?

3. How does geogenic As enrichment at Black Mountain Open Space Park affect plant and wildlife? 


\subsection{Work cited}

Hack, A.C., J.A. Mavrogenes, 2006. A synthetic fluid inclusion study of copper solubility in hydrothermal brines from 525 to $725 \mathrm{C}$ and 0.3 to $1.7 \mathrm{GPa}$. Geochim, et Cosmochim. Acta 70(15): 3970-3985.

Hattori, K.H., S. Guillot, 2003. Volcanic fronts form as a consequence of serpentinite on the forearc mantle wedge. Geol. 31(6): 525-528.

Herzig, C.T., D.L. Kimbrough, 2014. Santiago peak volcanics: Early Cretaceous arc volcanism of the western Peninsular Ranges batholith, southern California. GSA Memoir 211: 345363.

Smedley, P.L., D.G. Kinniburgh, 2001. A review of the source, behaviour and distribution of arsenic in natural waters. Appl. Geochem. 17: 517-668. 
APPENDIX A: Sample locations

\begin{tabular}{|c|c|c|}
\hline Sample ID & Latitude & Longitude \\
\hline R001i & 32.99292 & -117.11329 \\
\hline R002wp & 32.99331 & -117.11061 \\
\hline R003wp & 32.99331 & -117.11061 \\
\hline R004i & 32.99329 & -117.11086 \\
\hline R005wp & 32.99331 & -117.11061 \\
\hline R006i & 32.99327 & -117.11083 \\
\hline R007wp & 32.99325 & -117.11084 \\
\hline R008f & 33.03348 & -117.12427 \\
\hline R009f & 32.98861 & -117.11211 \\
\hline R010f & 33.03352 & -117.12445 \\
\hline R011i & 33.03349 & -117.12428 \\
\hline R012f & 32.992672 & -117.11568 \\
\hline R013f & 32.992672 & -117.11568 \\
\hline R014f & 33.033043 & -117.12011 \\
\hline R015f & 33.033043 & -117.12011 \\
\hline R016f & 33.03352 & -117.12445 \\
\hline R017f & 33.033043 & -117.12011 \\
\hline R018f & 33.033043 & -117.12011 \\
\hline R019f & 32.98861 & -117.11211 \\
\hline R020i & 32.98885 & -117.11236 \\
\hline R021i & 32.99295 & -117.10976 \\
\hline R022i & 32.98974 & -117.11196 \\
\hline R023i & 32.98974 & -117.11196 \\
\hline R024wp & 32.99024 & -117.11132 \\
\hline R025i & 32.993056 & -117.113056 \\
\hline R026i & 32.9925 & -117.113056 \\
\hline R027wp & 32.981389 & -117.113056 \\
\hline R028f & 32.973056 & -117.120833 \\
\hline R029i & 32.976389 & -117.121111 \\
\hline R030f & 32.976667 & -117.120556 \\
\hline R031i & 32.976111 & -117.117222 \\
\hline R032wp & 32.981389 & -117.113056 \\
\hline R033f & 32.99083333 & -117.1119444 \\
\hline R034f & 32.99111111 & -117.1125 \\
\hline R035wp & 32.99138889 & -117.1130556 \\
\hline R036i & 32.99055556 & -117.1113889 \\
\hline $\mathrm{R} 037 \mathrm{i}$ & 32.98972222 & -117.1119444 \\
\hline R038i & 32.99000 & -117.1111111 \\
\hline
\end{tabular}




\begin{tabular}{|c|c|c|}
\hline Sample ID & Latitude & Longitude \\
\hline R039i & 32.99 & -117.1116667 \\
\hline R040i & 32.98972222 & -117.1119444 \\
\hline R041i & 32.99 & -117.1116667 \\
\hline R042i & 32.99027778 & -117.1113889 \\
\hline R043wp & 32.99027778 & -117.1113889 \\
\hline $\mathrm{R} 044 \mathrm{i}$ & 32.99138889 & -117.1122222 \\
\hline R045f & 32.99027778 & -117.1113889 \\
\hline R046i & 32.993611 & -117.110833 \\
\hline R047f & 32.9975 & -117.115488 \\
\hline $\mathrm{R} 048 \mathrm{i}$ & 32.99111111 & -117.1152778 \\
\hline R049i & 32.99027778 & -117.1116667 \\
\hline R050f & 32.990421 & -117.111697 \\
\hline R051i & 32.99055556 & -117.1108333 \\
\hline R052f & 32.99055556 & -117.1111111 \\
\hline R053i & 32.99055556 & -117.1111111 \\
\hline R054i & 32.99055556 & -117.1102778 \\
\hline R055i & 32.99111111 & -117.110556 \\
\hline R056f & 32.990921 & -117.11032 \\
\hline R057i & 32.99111111 & -117.11 \\
\hline $\mathrm{R} 058 \mathrm{i}$ & 32.99166667 & -117.11 \\
\hline R059i & 32.99166667 & -117.11 \\
\hline R060i & 32.99222222 & -117.1094444 \\
\hline R061i & 32.99277778 & -117.1097222 \\
\hline R062i & 32.99305556 & -117.1097222 \\
\hline R063i & 32.9888 & -117.11278 \\
\hline R064i & 32.991667 & -117.11 \\
\hline R065i & 32.989953 & -117.11204 \\
\hline R066i & 32.991434 & -117.110306 \\
\hline R067i & 32.989722 & -117.113056 \\
\hline Mk001 & 32.98974 & -117.11196 \\
\hline $\mathrm{Mk} 002$ & 32.98974 & -117.11196 \\
\hline Mk003 & 32.98974 & -117.11196 \\
\hline Mk004 & 32.98974 & -117.11196 \\
\hline $\mathrm{Mk} 005$ & 32.98974 & -117.11196 \\
\hline Mk006 & 32.98974 & -117.11196 \\
\hline Mr001 & 32.98868 & -117.11211 \\
\hline Mr002 & 32.98868 & -117.11211 \\
\hline Mr003 & 32.98868 & -117.11211 \\
\hline Mr004 & 32.98868 & -117.11211 \\
\hline Mr005 & 32.98868 & -117.11211 \\
\hline Mr006 & 32.98868 & -117.11211 \\
\hline
\end{tabular}


APPENDIX B: Trace metals in rhyolites and dacites $(\mathrm{n}=20)$

\begin{tabular}{|c|c|c|c|c|c|c|c|}
\hline & & As (ppm) & $\mathrm{Cu}(\mathrm{ppm})$ & $\mathrm{Pb}(\mathrm{ppm})$ & $\mathrm{S}(\mathrm{ppm})$ & $\mathrm{Sb}(\mathrm{ppm})$ & $\mathrm{Zn}(\mathrm{ppm})$ \\
\hline Mr001 & Rhyolite & 347 & 17 & 12 & 483 & 0 & 14 \\
\hline MrO02 & Rhyolite & 1,024 & 53 & 33 & 0 & 0 & 65 \\
\hline R004i & Rhyolite & 109 & 67 & 57 & 0 & 23 & 23.7 \\
\hline R020i & Rhyolite & 3155 & 11 & 33.4 & 0 & 0 & 72 \\
\hline R021i & Rhyolite & 12.6 & 12 & 19 & 0 & 0 & 43.7 \\
\hline R024wp & Rhyolite & 734 & 42 & 29.5 & 0 & 0 & 32.4 \\
\hline R037i & Rhyolite & 305 & 27 & 26 & 497 & 0 & 14 \\
\hline R044i & Rhyolite & 158 & 18 & 15.1 & 0 & 13 & 57 \\
\hline R046i & Rhyolite & 7.2 & 38 & 27 & 0 & 0 & 84 \\
\hline R060i & Rhyolite & 5.5 & 18 & 28.2 & 0 & 0 & 52 \\
\hline R038i & Dacite & 24.8 & 19 & 27 & 0 & 0 & 31 \\
\hline R039i & Dacite & 10.8 & 23 & 11.8 & 0 & 0 & 89 \\
\hline R049i & Dacite & 5.2 & 17 & 15.2 & 0 & 0 & 125 \\
\hline R051i & Dacite & 11 & 37 & 14 & 0 & 0 & 161 \\
\hline R053i & Dacite & 16.6 & 47 & 0 & 0 & 0 & 178 \\
\hline R054i & Dacite & 9 & 22 & 6 & 0 & 0 & 126 \\
\hline R055i & Dacite & 6.3 & 33 & 13.1 & 0 & 0 & 113 \\
\hline R058i & Dacite & 31.6 & 41 & 10.3 & 0 & 0 & 121 \\
\hline R065i & Dacite & 15 & 38 & 8 & 0 & 0 & 114 \\
\hline R066i & Dacite & 9 & 20 & 14.2 & 0 & 0 & 85 \\
\hline
\end{tabular}


APPENDIX C: Trace metals in all samples and subsamples $(\mathrm{n}=168)$

\begin{tabular}{|c|c|c|c|c|c|}
\hline Sample ID & As (ppm) & $\mathrm{Cu}(\mathrm{ppm})$ & $\mathrm{Pb}(\mathrm{ppm})$ & $\mathrm{Sb}(\mathrm{ppm})$ & $\mathrm{Zn}(\mathrm{ppm})$ \\
\hline R001i_Bulk & 4 & 7 & 16 & 0 & 34 \\
\hline R002wp_Bulk* & 50 & 27 & 17 & 0 & 14 \\
\hline R002wp_f* & 113 & 279 & 32 & 80 & 56 \\
\hline R002wp_w* & 663 & 367 & 0 & 143 & 156 \\
\hline R003wp_Bulk* & 267 & 123 & 17 & 18 & 62 \\
\hline R003wp_f* & 121 & 130 & 45 & 81 & 96 \\
\hline R003wp_w* & 958 & 484 & 565 & 117 & 304 \\
\hline R004i_Bulk & 109 & 67 & 57 & 23 & 23.7 \\
\hline R004i_f & 50 & 71 & 44 & 98 & 41 \\
\hline R004i_w & 598 & 510 & 644 & 118 & 100 \\
\hline R005wp_f & 64 & 232 & 72 & 65 & 52 \\
\hline R005wp_w & 2,007 & 461 & 523 & 85 & 170 \\
\hline R006i_Bulk & 17 & 20 & 12 & 0 & 29 \\
\hline R006i_f & 59 & 97 & 91 & 62 & 72 \\
\hline R006i_w & 185 & 38 & 0 & 26 & 46 \\
\hline R007wp_Bulk* & 5 & 12 & 23 & 0 & 49 \\
\hline R007wp_f* & 11 & 50 & 76 & 35 & 97 \\
\hline R007wp_w* & 39 & 62 & 48 & 0 & 166 \\
\hline R008f_Bulk & 2,787 & 66 & 50 & 20 & 197 \\
\hline R008f_w & 6,658 & 0 & 0 & 79 & 377 \\
\hline R009f_Bulk & 244 & 22 & 10 & 0 & 34 \\
\hline R009f_f & 494 & 200 & 49 & 46 & 86 \\
\hline R009f_w & 2,167 & 46 & 26 & 22 & 31 \\
\hline R010f_Bulk & 806 & 42 & 508 & 19 & 37 \\
\hline R010f_w & 659 & 0 & 629 & 33 & 26 \\
\hline R011i_Bulk & 35 & 0 & 0 & 0 & 10 \\
\hline R012f_Bulk & 14 & 45 & 66 & 0 & 35 \\
\hline R014f_f & 8 & 102 & 37 & 68 & 39 \\
\hline R014f_w & 359 & 47 & 213 & 60 & 83 \\
\hline R015f_Bulk & $\mathbf{0}$ & 62 & 1,007 & 42 & 276 \\
\hline R015f_f & 28 & 18 & 44 & 41 & 110 \\
\hline R015f_w & 85 & 35 & 0 & 0 & 135 \\
\hline R016f_Bulk & 24 & 28 & 8 & 0 & 41 \\
\hline R016f_f & 114 & 53 & 15 & 51 & 52 \\
\hline R016f_w & 550 & 26 & 364 & 26 & 43 \\
\hline R016f_w2 & 29 & 34 & 6 & 0 & 34 \\
\hline R016f_w3 & 396 & 0 & 0 & 88 & 0 \\
\hline
\end{tabular}




\begin{tabular}{|c|c|c|c|c|c|}
\hline Sample ID & As (ppm) & $\mathrm{Cu}(\mathrm{ppm})$ & $\mathrm{Pb}(\mathrm{ppm})$ & $\mathrm{Sb}(\mathrm{ppm})$ & $\mathrm{Zn}(\mathrm{ppm})$ \\
\hline R017f_Bulk & 53 & 19 & 8 & 10 & 12 \\
\hline R017f_f & 88 & 0 & 40 & 166 & 64 \\
\hline R017f_w & 296 & 50 & 18 & 98 & 68 \\
\hline R017f_w2 & 575 & 84 & 0 & 111 & 146 \\
\hline R017f_w3 & 327 & 120 & 348 & 27 & 126 \\
\hline R018f_f & 172 & 33 & 38 & 41 & 149 \\
\hline R018f_w & 113 & 84 & 40 & 0 & 120 \\
\hline R018f_w2 & 185 & 98 & 203 & 107 & 163 \\
\hline R019wp_f* & 274 & 0 & 37 & 177 & 0 \\
\hline R019wp_w* & 1,321 & 0 & 31 & 195 & 31 \\
\hline R019wp_w2* & 5,460 & 0 & 42 & 212 & 0 \\
\hline R020i_Bulk & 3155 & 11 & 33.4 & 0 & 72 \\
\hline R020i_f & 6,211 & 31 & 42 & 93 & 91 \\
\hline R020i_w & 142,291 & 0 & 119 & 98 & 81 \\
\hline R021i_Bulk & 12.6 & 12 & 19 & 0 & 43.7 \\
\hline R021i_f & $\mathbf{0}$ & 32 & 48 & 0 & 69 \\
\hline R021i_w & 48 & 163 & 57 & 0 & 157 \\
\hline R022i_Bulk* & 175,294 & 1,075 & 227 & 190 & 0 \\
\hline R022i_2* & 131,687 & 937 & 152 & 124 & 0 \\
\hline R022i_pyrite* & 7,518 & 678 & 260 & 30 & 36 \\
\hline R023i_Bulk* & 28,795 & 891 & 0 & 110 & 0 \\
\hline R023i_2* & 32,822 & 1,154 & 183 & 85 & 0 \\
\hline R023i_pyrite* & 19,777 & 1,153 & 261 & 22 & 0 \\
\hline R024wp_Bulk* & 734 & 42 & 29.5 & 0 & 32.4 \\
\hline R024wp_f* & 562 & 50 & 29 & 151 & 39 \\
\hline R024wp_w* & 5,274 & 199 & 304 & 45 & 124 \\
\hline R026i_Bulk & 3 & 9 & 10 & 0 & 46 \\
\hline R027wp_f* & 116 & 0 & 44 & 105 & 132 \\
\hline R027wp_w* & 1,038 & 24 & 291 & 24 & 474 \\
\hline R027wp_w2* & 860 & 0 & 0 & 65 & 516 \\
\hline R028f_Bulk & 9 & 25 & 9 & 0 & 82 \\
\hline R029i_Bulk & 18 & 26 & 18 & 0 & 78 \\
\hline R029i_f & 36 & 27 & 0 & 43 & 133 \\
\hline R029i_w & 240 & 37 & 122 & 0 & 92 \\
\hline R030f_Bulk & 13 & 13 & 23 & 0 & 100 \\
\hline R031i_Bulk & 183 & 25 & 8 & 10 & 45 \\
\hline R032wp_Bulk* & 21 & 15 & 14 & 0 & 28 \\
\hline R032wp_w* & 365 & 37 & 241 & 24 & 525 \\
\hline R033f_f & 42 & 46 & 125 & 87 & 403 \\
\hline
\end{tabular}




\begin{tabular}{|c|c|c|c|c|c|}
\hline Sample ID & As (ppm) & $\mathrm{Cu}(\mathrm{ppm})$ & $\mathrm{Pb}(\mathrm{ppm})$ & $\mathrm{Sb}(\mathrm{ppm})$ & $\mathrm{Zn}(\mathrm{ppm})$ \\
\hline R033f_w & 85 & 37 & 16 & 0 & 214 \\
\hline R034f_f & 116 & 38 & 125 & 67 & 934 \\
\hline R034f_w & 2,674 & 95 & 0 & 70 & 201 \\
\hline R035wp_f* & 76 & 96 & 112 & 106 & 170 \\
\hline R035wp_w* & 126 & 42 & 18 & 0 & 81 \\
\hline R036i_f & 41 & 54 & 16 & 44 & 155 \\
\hline R036i_w & 122 & 29 & 18 & 0 & 130 \\
\hline R037i_Bulk & 305 & 27 & 26 & 0 & 14 \\
\hline R037i_2 & 4,259 & 148 & 502 & 47 & 85 \\
\hline R038i_Bulk & 24.8 & 19 & 27 & 0 & 31 \\
\hline R038i_f & 35 & 101 & 34 & 93 & 117 \\
\hline R038i_w & 116 & 10 & 30 & 0 & 84 \\
\hline R039i_Bulk & 10.8 & 23 & 11.8 & 0 & 89 \\
\hline R039i_f & 13 & 28 & 0 & 0 & 86 \\
\hline R039i_w & 598 & 120 & 109 & 96 & 180 \\
\hline R040i_Bulk & 92 & 27 & 0 & 0 & 56 \\
\hline R040i_f & 1,214 & 53 & 0 & 44 & 203 \\
\hline R040i_w & 161 & 45 & 37 & 0 & 97 \\
\hline R041i_f & 20 & 17 & 0 & 0 & 97 \\
\hline R041i_w & 193 & 34 & 48 & 84 & 107 \\
\hline R042i_f & 21 & 15 & 7 & 0 & 97 \\
\hline R042i_w & 315 & 63 & 55 & 36 & 216 \\
\hline R043wp_f* & 244 & 10 & 9 & 0 & 11 \\
\hline R043wp_w* & 27,473 & 163 & 437 & 57 & 168 \\
\hline R044i_Bulk & 158 & 18 & 15.1 & 13 & 57 \\
\hline R044i_f* & 224 & 64 & 37 & 186 & 105 \\
\hline R044i_w* & 10,205 & 323 & 0 & 129 & 336 \\
\hline R045f_f & 31 & 61 & 19 & 50 & 184 \\
\hline R045f_w & 452 & 45 & 0 & 47 & 275 \\
\hline R046i_Bulk & 7.2 & 38 & 27 & 0 & 84 \\
\hline R046i_f & $\mathbf{0}$ & 9 & 12 & 0 & 30 \\
\hline R046i_w & 15 & 0 & 20 & 184 & 63 \\
\hline R047f_f & 23 & 36 & 0 & 104 & 173 \\
\hline R047f_w & 97 & 23 & 0 & 36 & 206 \\
\hline R048i_f & 36 & 0 & 32 & 143 & 45 \\
\hline R048i_w & 161 & 44 & 30 & 81 & 150 \\
\hline R049i_Bulk & 5.2 & 17 & 15.2 & 0 & 125 \\
\hline R049i_porphyry & $\mathbf{0}$ & 0 & 35 & 120 & 29 \\
\hline R049i_matrix & 11 & 0 & 22 & 55 & 210 \\
\hline
\end{tabular}




\begin{tabular}{|c|c|c|c|c|c|}
\hline Sample ID & As (ppm) & $\mathrm{Cu}(\mathrm{ppm})$ & $\mathrm{Pb}(\mathrm{ppm})$ & $\mathrm{Sb}(\mathrm{ppm})$ & $\mathrm{Zn}(\mathrm{ppm})$ \\
\hline R050f_porphyry & 71 & 87 & 79 & 52 & 84 \\
\hline R050f_matrix & 41 & 0 & 0 & 57 & 243 \\
\hline R051i_Bulk & 11 & 37 & 14 & 0 & 161 \\
\hline R051i_f & 63 & 28 & 65 & 56 & 166 \\
\hline R051i_w & $\mathbf{0}$ & 32 & 25 & 88 & 78 \\
\hline R052f_f & 13 & 122 & 66 & 0 & 124 \\
\hline R053i_Bulk & 16.6 & 47 & 0 & 0 & 178 \\
\hline R053i_f & 19 & 133 & 30 & 45 & 205 \\
\hline R054i_Bulk & 9 & 22 & 6 & 0 & 126 \\
\hline R055i_Bulk & 6.3 & 33 & 13.1 & 0 & 113 \\
\hline R055i_f & 13 & 29 & 52 & 68 & 136 \\
\hline R055i_w & 37 & 68 & 17 & 73 & 94 \\
\hline R056f_f & 335 & 27 & 59 & 68 & 60 \\
\hline R056f_w & 31,235 & 440 & 103 & 118 & 149 \\
\hline R057i_f & $\mathbf{0}$ & 0 & 23 & 154 & 89 \\
\hline R057i_w & $\mathbf{0}$ & 0 & 29 & 114 & 30 \\
\hline R058i_Bulk & 31.6 & 41 & 10.3 & 0 & 121 \\
\hline R058i_f & 0 & 0 & 27 & 163 & 61 \\
\hline R058i_w & $\mathbf{0}$ & 0 & 22 & 173 & 173 \\
\hline R059i_f & 16 & 69 & 185 & 59 & 21 \\
\hline R060i_Bulk & 5.5 & 18 & 28.2 & 0 & 52 \\
\hline R060i_f & 11 & 13 & 17 & 0 & 27 \\
\hline R061i_f & $\mathbf{0}$ & 0 & 36 & 94 & 0 \\
\hline R061i_w & 40 & 139 & 29 & 101 & 404 \\
\hline R062i_f & 20 & 66 & 110 & 37 & 175 \\
\hline R063i_f & 87 & 30 & 0 & 0 & 191 \\
\hline R064i_f & 25 & 71 & 57 & 36 & 476 \\
\hline R065i_Bulk & 15 & 38 & 8 & 0 & 114 \\
\hline R065i_f & 46 & 43 & 0 & 45 & 1,795 \\
\hline R066i_Bulk & 9 & 20 & 14.2 & 0 & 85 \\
\hline R066i_f & 37 & 0 & 31 & 40 & 149 \\
\hline R067i_f & 69 & 50 & 21 & 82 & 375 \\
\hline Mr001_Bulk & 347 & 17 & 12 & 0 & 14 \\
\hline Mr001_f* & 1,397 & 46 & 21 & 47 & 33 \\
\hline Mr001_w* & 6,048 & 132 & 64 & 38 & 43 \\
\hline Mr001_w2* & 7,812 & 169 & 66 & 16 & 27 \\
\hline Mr002_Bulk & 1,024 & 53 & 33 & 0 & 65 \\
\hline Mr002_f* & 8,944 & 61 & 36 & 58 & 289 \\
\hline Mr002_w* & 25,915 & 132 & 0 & 73 & 678 \\
\hline
\end{tabular}




\begin{tabular}{c|ccccc} 
Sample ID & As (ppm) & $\mathrm{Cu}(\mathrm{ppm})$ & $\mathrm{Pb}(\mathrm{ppm})$ & $\mathrm{Sb}(\mathrm{ppm})$ & $\mathrm{Zn}(\mathrm{ppm})$ \\
\hline Mr002_w2* & $\mathbf{1 6 7 , 0 7 0}$ & 0 & 173 & 70 & 0 \\
Mr003_f* & $\mathbf{1 0 1}$ & 51 & 0 & 29 & 146 \\
Mr003_w* & $\mathbf{2 9 7}$ & 36 & 13 & 0 & 65 \\
Mr004_f* & $\mathbf{3 7 0}$ & 68 & 12 & 72 & 215 \\
Mr004_w* & $\mathbf{2 , 8 1 4}$ & 99 & 159 & 52 & 161 \\
Mr005* & $\mathbf{1 , 4 7 9}$ & 67 & 0 & 23 & 309 \\
Mr006_f* & $\mathbf{1 , 7 9 9}$ & 146 & 15 & 81 & 238 \\
Mr006_w* & $\mathbf{4 , 1 9 1}$ & 287 & 0 & 57 & 111 \\
Mk001* & $\mathbf{4 9 , 6 6 0}$ & 67 & 351 & 0 & 0 \\
Mk002* & $\mathbf{3 7 5}$ & 81 & 291 & 0 & 97 \\
Mk003* & $\mathbf{9 2 3}$ & 78 & 0 & 0 & 151 \\
Mk004* & $\mathbf{2 9 7 , 1 5 6}$ & 0 & 0 & 211 & 0 \\
Mk005* & $\mathbf{8 , 5 0 7}$ & 489 & 0 & 0 & 56 \\
Mk006* & $\mathbf{9 3 0}$ & 762 & 231 & 78 & 169 \\
& & & & &
\end{tabular}


APPENDIX D: Arsenic correlation with lead $(\mathrm{Pb})$, antimony $(\mathrm{Sb})$, copper $(\mathrm{Cu})$, and zinc $(\mathrm{Zn})$

$$
\mathrm{n}=168
$$
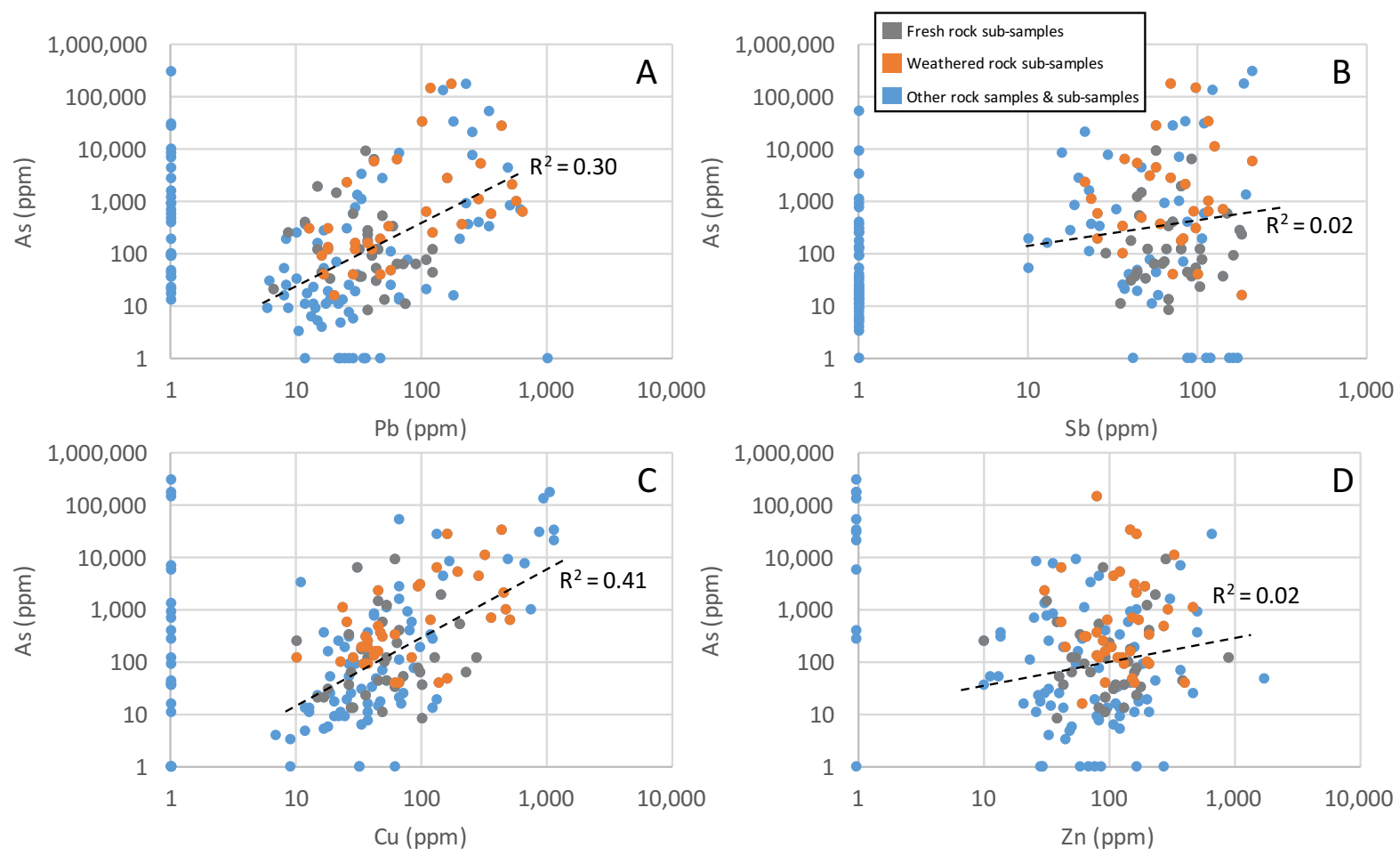

$* \mathrm{R}^{2}$ value was calculated for points where both metals were detected 
APPENDIX E: Trace metal content in fresh versus weathered subsamples of Black Mountain $\operatorname{SPV}(n=44)$
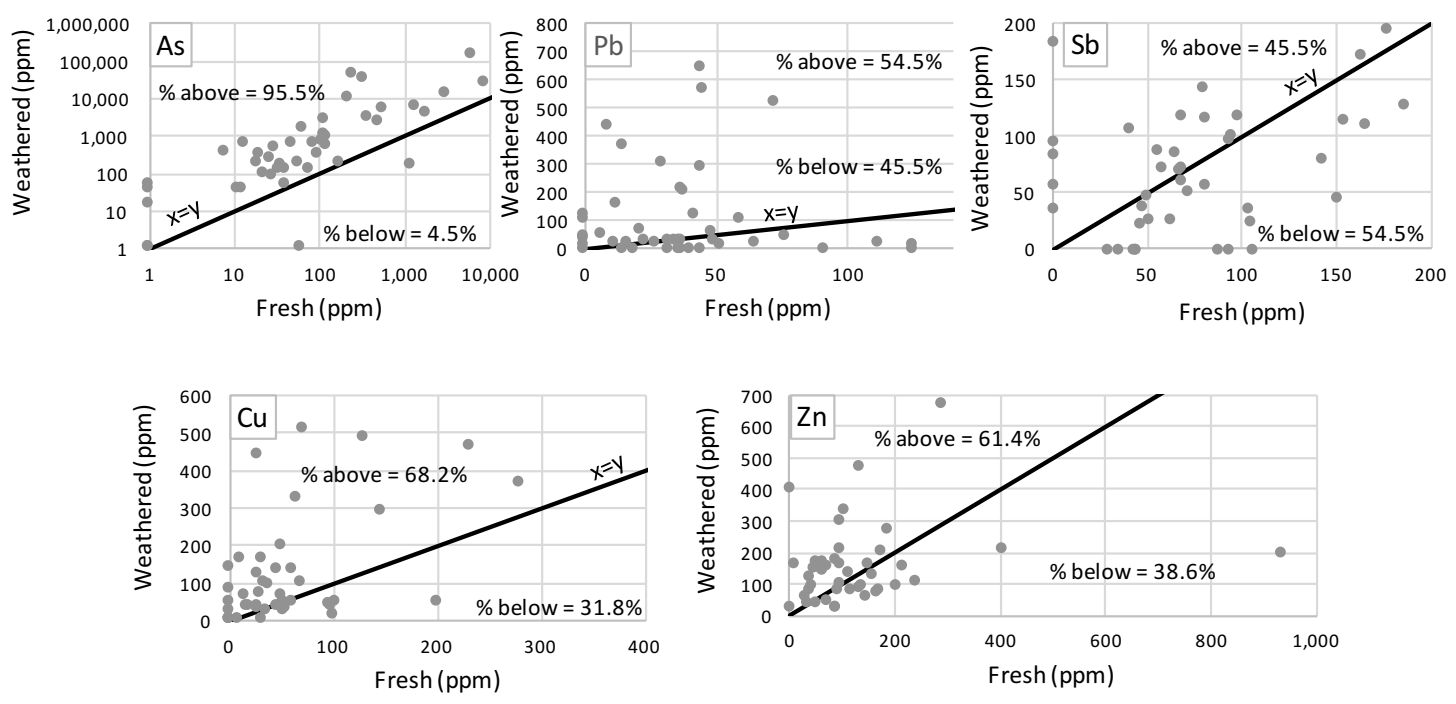
APPENDIX F: XRD results for all samples and subsamples $(\mathrm{n}=168)$

\begin{tabular}{|c|c|c|}
\hline Sample ID & Minerals present (XRD results) & Score* \\
\hline R001i & $\begin{array}{l}\text { Quartz } \\
\text { Albite low }\end{array}$ & $\begin{array}{l}77 \\
32\end{array}$ \\
\hline R002wp & $\begin{array}{l}\text { Quartz } \\
\text { Albite } \\
\text { Orthoclase }\end{array}$ & $\begin{array}{l}63 \\
49 \\
36 \\
\end{array}$ \\
\hline R002wp_f & $\begin{array}{l}\text { Quartz } \\
\text { Albite low }\end{array}$ & $\begin{array}{l}74 \\
35\end{array}$ \\
\hline R002wp_w & $\begin{array}{l}\text { Quartz } \\
\text { Goethite }\end{array}$ & $\begin{array}{l}61 \\
43\end{array}$ \\
\hline R003wp & $\begin{array}{l}\text { Quartz } \\
\text { Albite low } \\
\text { Magnetite } \\
\text { Goethite }\end{array}$ & $\begin{array}{l}66 \\
47 \\
36 \\
22\end{array}$ \\
\hline R003wp_f & $\begin{array}{l}\text { Quartz } \\
\text { Albite low }\end{array}$ & $\begin{array}{l}76 \\
36\end{array}$ \\
\hline R003wp_w & $\begin{array}{l}\text { Quartz } \\
\text { Goethite } \\
\text { Kusachiite }\end{array}$ & $\begin{array}{l}70 \\
30 \\
24\end{array}$ \\
\hline R004i & $\begin{array}{l}\text { Quartz } \\
\text { Albite low } \\
\text { Magnetite }\end{array}$ & $\begin{array}{l}54 \\
42 \\
26\end{array}$ \\
\hline R004i_f & $\begin{array}{l}\text { Quartz } \\
\text { Albite } \\
\text { Biotite }\end{array}$ & $\begin{array}{l}70 \\
34 \\
13 \\
\end{array}$ \\
\hline R004i_w & $\begin{array}{l}\text { Quartz } \\
\text { Goethite }\end{array}$ & $\begin{array}{l}52 \\
45\end{array}$ \\
\hline R005wp_f & $\begin{array}{l}\text { Quartz } \\
\text { Albite low } \\
\text { Biotite }\end{array}$ & $\begin{array}{l}72 \\
35 \\
21\end{array}$ \\
\hline R005wp_w & $\begin{array}{l}\text { Quartz } \\
\text { Goethite } \\
\text { Albite low }\end{array}$ & $\begin{array}{l}64 \\
40 \\
26\end{array}$ \\
\hline R006i & $\begin{array}{l}\text { Quartz } \\
\text { Albite, ordered } \\
\text { Roscoelite }\end{array}$ & $\begin{array}{l}52 \\
49 \\
29\end{array}$ \\
\hline R006i_f & $\begin{array}{l}\text { Quartz } \\
\text { Albite, Ca-rich, ordered }\end{array}$ & $\begin{array}{l}71 \\
35\end{array}$ \\
\hline
\end{tabular}




\begin{tabular}{|c|c|c|}
\hline Sample ID & Minerals present (XRD results) & Score* \\
\hline R006i_w & $\begin{array}{l}\text { Quartz } \\
\text { Volkonskoite } \\
\text { Metaschoepite }\end{array}$ & $\begin{array}{l}66 \\
36 \\
28\end{array}$ \\
\hline R007wp & $\begin{array}{l}\text { Quartz } \\
\text { Albite, Ca-rich, ordered } \\
\text { Rectorite }\end{array}$ & $\begin{array}{l}58 \\
37 \\
26 \\
\end{array}$ \\
\hline R007wp_f & $\begin{array}{l}\text { Quartz } \\
\text { Albite low } \\
\text { Biotite }\end{array}$ & $\begin{array}{l}76 \\
36 \\
22 \\
\end{array}$ \\
\hline R007wp_w & $\begin{array}{l}\text { Quartz } \\
\text { Kusachiite } \\
\text { Eastonite } \\
\end{array}$ & $\begin{array}{l}70 \\
16 \\
16\end{array}$ \\
\hline R008f & $\begin{array}{l}\text { Quartz } \\
\text { Illite } \\
\text { Goethite } \\
\text { Rutile } \\
\text { Muscovite } \\
\text { Hematite } \\
\end{array}$ & $\begin{array}{l}48 \\
35 \\
36 \\
29 \\
37 \\
20 \\
\end{array}$ \\
\hline R008f_w & $\begin{array}{l}\text { Quartz } \\
\text { Hematite } \\
\text { Goethite } \\
\end{array}$ & $\begin{array}{l}62 \\
40 \\
15 \\
\end{array}$ \\
\hline R009f & $\begin{array}{l}\text { Quartz } \\
\text { Albite, ordered } \\
\text { Ankerite } \\
\text { Muscovite (NH4 -rich) } \\
\text { Vermiculite } \\
\end{array}$ & $\begin{array}{l}59 \\
55 \\
23 \\
27 \\
16\end{array}$ \\
\hline R009f_f & $\begin{array}{l}\text { Quartz } \\
\text { Albite, Ca-rich, ordered } \\
\text { Biotite }\end{array}$ & $\begin{array}{l}71 \\
39 \\
30 \\
\end{array}$ \\
\hline R009f_w & $\begin{array}{l}\text { Quartz } \\
\text { Albite, ordered } \\
\text { Kaolinite } \\
\text { Illite } \\
\text { Paranatisite } \\
\end{array}$ & $\begin{array}{l}66 \\
36 \\
42 \\
14 \\
14 \\
\end{array}$ \\
\hline R010f & $\begin{array}{l}\text { Hematite } \\
\text { Quartz } \\
\text { Goethite } \\
\text { Goldfieldite } \\
\text { Pseudorutile } \\
\end{array}$ & $\begin{array}{l}67 \\
43 \\
34 \\
22 \\
26\end{array}$ \\
\hline
\end{tabular}




\begin{tabular}{|c|c|c|}
\hline Sample ID & Minerals present (XRD results) & Score* \\
\hline R010f_w & $\begin{array}{l}\text { Hematite } \\
\text { Quartz } \\
\text { Goethite }\end{array}$ & $\begin{array}{l}76 \\
38 \\
21 \\
\end{array}$ \\
\hline R011i & Quartz & 61 \\
\hline R012f & $\begin{array}{l}\text { Quartz } \\
\text { Albite, Ca-rich, ordered } \\
\text { Mica } \\
\text { Calcite } \\
\text { Birnessite } \\
\text { Muscovite }\end{array}$ & $\begin{array}{l}70 \\
34 \\
36 \\
34 \\
22 \\
19\end{array}$ \\
\hline R014f_f & Quartz & 78 \\
\hline R014f_w & $\begin{array}{l}\text { Baumite } \\
\text { Kaolinite } \\
\text { Quartz low }\end{array}$ & $\begin{array}{l}46 \\
40 \\
36 \\
\end{array}$ \\
\hline R015f & Goethite & 77 \\
\hline R015f_f & $\begin{array}{l}\text { Quartz } \\
\text { Polylithionite, Fe-rich } \\
\text { Brucite } \\
\text { Albite, Ca-rich, ordered } \\
\text { Gobbinsite }\end{array}$ & $\begin{array}{l}75 \\
39 \\
30 \\
14 \\
13\end{array}$ \\
\hline R015f_w & \begin{tabular}{|l|} 
Goethite \\
Spangolite \\
\end{tabular} & $\begin{array}{l}69 \\
10 \\
\end{array}$ \\
\hline R015f_w_SDSUduplicate & Goethite & 41 \\
\hline R016f & \begin{tabular}{|l} 
Quartz \\
Muscovite \\
Gobbinsite \\
Zemannite \\
\end{tabular} & $\begin{array}{l}65 \\
42 \\
20 \\
12 \\
\end{array}$ \\
\hline R016f_f & $\begin{array}{l}\text { Quartz } \\
\text { Muscovite } \\
\text { Zinnwaldite }\end{array}$ & $\begin{array}{l}73 \\
27 \\
17 \\
\end{array}$ \\
\hline R016f_w & \begin{tabular}{|l|} 
Hematite \\
Quartz \\
\end{tabular} & $\begin{array}{l}73 \\
60 \\
\end{array}$ \\
\hline R016f_w2 & $\begin{array}{l}\text { Quartz } \\
\text { Muscovite } \\
\text { Hematite } \\
\text { Illite }\end{array}$ & $\begin{array}{l}71 \\
53 \\
40 \\
41\end{array}$ \\
\hline R016f_w3 & $\begin{array}{l}\text { Hematite } \\
\text { Quartz } \\
\text { Giniite, Fe-rich }\end{array}$ & $\begin{array}{l}63 \\
47 \\
26 \\
\end{array}$ \\
\hline
\end{tabular}




\begin{tabular}{|c|c|c|}
\hline Sample ID & Minerals present (XRD results) & Score* \\
\hline R017f & $\begin{array}{l}\text { Quartz } \\
\text { Baumite } \\
\text { Maricite } \\
\text { Andalusite }\end{array}$ & $\begin{array}{l}52 \\
32 \\
29 \\
23\end{array}$ \\
\hline R017f_f & $\begin{array}{l}\text { Quartz } \\
\text { Sodalite } \\
\text { Mica } \\
\text { Birnessite } \\
\text { Zinnwaldite } \\
\text { Claudetite } \\
\text { Kroehnkite } \\
\end{array}$ & $\begin{array}{c}75 \\
38 \\
44 \\
35 \\
20 \\
20 \\
9\end{array}$ \\
\hline R017f_w & $\begin{array}{l}\text { Quartz } \\
\text { Sodalite } \\
\text { Birnessite } \\
\text { Braunite } \\
\text { Kroehnkite }\end{array}$ & $\begin{array}{c}78 \\
28 \\
23 \\
15 \\
7\end{array}$ \\
\hline R017f_w2 & $\begin{array}{l}\text { Quartz } \\
\text { Hematite } \\
\text { Goethite } \\
\text { Moissanite } \\
\text { Maucherite subcell } \\
\text { Baumite }\end{array}$ & $\begin{array}{l}69 \\
30 \\
25 \\
21 \\
25 \\
32\end{array}$ \\
\hline R017f_w3 & $\begin{array}{l}\text { Goethite } \\
\text { Baumite } \\
\text { Periclase } \\
\text { Muscovite (Ba-rich) } \\
\text { Quartz } \\
\end{array}$ & $\begin{array}{l}50 \\
30 \\
23 \\
31 \\
31\end{array}$ \\
\hline R018f_f & $\begin{array}{l}\text { Quartz } \\
\text { Mica } \\
\text { Zinnwaldite } \\
\text { Mgriite } \\
\end{array}$ & $\begin{array}{l}80 \\
20 \\
22 \\
14 \\
\end{array}$ \\
\hline R018f_w & $\begin{array}{l}\text { Goethite } \\
\text { Quartz } \\
\text { Hematite } \\
\text { Goldfieldite } \\
\text { Enstatite ferroan }\end{array}$ & $\begin{array}{c}69 \\
41 \\
53 \\
8 \\
14 \\
\end{array}$ \\
\hline R018f_w2 & $\begin{array}{l}\text { Quartz } \\
\text { Goethite } \\
\text { Hematite }\end{array}$ & $\begin{array}{l}71 \\
49 \\
44 \\
\end{array}$ \\
\hline
\end{tabular}




\begin{tabular}{|c|c|c|}
\hline Sample ID & Minerals present (XRD results) & Score* \\
\hline R019f_f & $\begin{array}{l}\text { Quartz } \\
\text { Albite, Ca-rich, ordered } \\
\text { Phlogopite }\end{array}$ & $\begin{array}{l}73 \\
34 \\
15 \\
\end{array}$ \\
\hline R019f_w & $\begin{array}{l}\text { Quartz } \\
\text { Fraipontite } \\
\text { Anorthite, ordered } \\
\end{array}$ & $\begin{array}{l}60 \\
39 \\
28 \\
\end{array}$ \\
\hline R019f_w2 & $\begin{array}{l}\text { Quartz } \\
\text { Heulandite } \\
\text { Fraipontite } \\
\text { Magnetite } \\
\text { Phlogopite } \\
\end{array}$ & $\begin{array}{l}64 \\
31 \\
23 \\
19 \\
15\end{array}$ \\
\hline R020i_f & \begin{tabular}{|l} 
Quartz \\
Albite low \\
Moissanite \\
Microcline intermediate \\
\end{tabular} & $\begin{array}{l}68 \\
39 \\
30 \\
13\end{array}$ \\
\hline R020i_w & $\begin{array}{l}\text { Quartz } \\
\text { Scorodite } \\
\text { Bariumpharmacosiderite } \\
\text { Albite low } \\
\end{array}$ & $\begin{array}{l}54 \\
47 \\
46 \\
28\end{array}$ \\
\hline R021i_f & $\begin{array}{l}\text { Quartz } \\
\text { Albite low }\end{array}$ & $\begin{array}{r}75 \\
31 \\
\end{array}$ \\
\hline R021i_w & \begin{tabular}{|l} 
Quartz \\
Albite \\
Eastonite \\
Heterogenite deuterated \\
\end{tabular} & $\begin{array}{l}71 \\
25 \\
21 \\
21\end{array}$ \\
\hline R022i & \begin{tabular}{|l|} 
Scorodite \\
Pyrite
\end{tabular} & $\begin{array}{l}59 \\
57 \\
\end{array}$ \\
\hline R022i_2 & \begin{tabular}{|l|}
$\begin{array}{l}\text { Scorodite } \\
\text { Pyrite }\end{array}$ \\
\end{tabular} & $\begin{array}{l}68 \\
58 \\
\end{array}$ \\
\hline R022i_pyrite & Pyrite & 67 \\
\hline R023i & \begin{tabular}{|l} 
Pyrite \\
Melanterite \\
\end{tabular} & $\begin{array}{l}70 \\
19 \\
\end{array}$ \\
\hline R023i_2 & $\begin{array}{l}\text { Pyrite } \\
\text { Montomorillonite } \\
\text { Scorodite } \\
\text { Rozenite } \\
\end{array}$ & $\begin{array}{l}71 \\
33 \\
40 \\
40\end{array}$ \\
\hline R023i_pyrite & Pyrite & 72 \\
\hline R023i_R022i_pyrite & Pyrite & 74 \\
\hline
\end{tabular}




\begin{tabular}{|c|c|c|}
\hline Sample ID & Minerals present (XRD results) & Score* \\
\hline R024wp & $\begin{array}{l}\text { Quartz } \\
\text { Albite low } \\
\text { Microcline intermediate } \\
\text { Enstatite ferroan }\end{array}$ & $\begin{array}{l}57 \\
53 \\
22 \\
26\end{array}$ \\
\hline R024wp_f & \begin{tabular}{|l|} 
Quartz \\
Albite low \\
\end{tabular} & $\begin{array}{l}69 \\
45 \\
\end{array}$ \\
\hline R024wp_w & \begin{tabular}{|l} 
Hematite \\
Quartz \\
Albite low \\
Goethite \\
\end{tabular} & $\begin{array}{l}61 \\
50 \\
28 \\
22 \\
\end{array}$ \\
\hline R026i & $\begin{array}{l}\text { Quartz } \\
\text { Albite, Ca-rich, ordered } \\
\text { Phlogopite, Fe-rich } \\
\text { Muscovite }\end{array}$ & $\begin{array}{l}66 \\
44 \\
21 \\
17\end{array}$ \\
\hline R027wp_f & $\begin{array}{l}\text { Quartz } \\
\text { Albite low } \\
\text { Dolomite, Ferroan } \\
\text { Lindackerite } \\
\end{array}$ & $\begin{array}{l}68 \\
39 \\
23 \\
18 \\
\end{array}$ \\
\hline R027wp_w & \begin{tabular}{|l|} 
Quartz \\
Westerveldite \\
\end{tabular} & $\begin{array}{l}44 \\
29 \\
\end{array}$ \\
\hline R027wp_w2 & $\begin{array}{l}\text { Quartz } \\
\text { Birnessite (K-exchanged) } \\
\text { Cryptohalite } \\
\text { Copper arsenate hydrate } \\
\text { Iowaite }\end{array}$ & $\begin{array}{l}49 \\
20 \\
21 \\
15 \\
18\end{array}$ \\
\hline R028f & $\begin{array}{l}\text { Quartz } \\
\text { Albite low } \\
\text { Clinochlore, Mn-rich } \\
\text { Rutile } \\
\text { Dickite }\end{array}$ & $\begin{array}{l}62 \\
34 \\
45 \\
22 \\
17\end{array}$ \\
\hline R029i & $\begin{array}{l}\text { Quartz } \\
\text { Clinochlore } \\
\text { Albite low } \\
\text { Muscovite }\end{array}$ & $\begin{array}{l}48 \\
36 \\
32 \\
33\end{array}$ \\
\hline R029i_f & $\begin{array}{l}\text { Quartz } \\
\text { Clinochlore ferroan } \\
\text { Mgriite } \\
\text { Albite low } \\
\text { Muscovite }\end{array}$ & $\begin{array}{l}66 \\
50 \\
53 \\
26 \\
15\end{array}$ \\
\hline
\end{tabular}




\begin{tabular}{|c|c|c|}
\hline Sample ID & Minerals present (XRD results) & Score* \\
\hline R029i_w & $\begin{array}{l}\text { Quartz } \\
\text { Volkonskoite } \\
\text { Nimite } \\
\text { Epidote }\end{array}$ & $\begin{array}{l}56 \\
47 \\
30 \\
29\end{array}$ \\
\hline R030f & $\begin{array}{l}\text { Quartz } \\
\text { Albite, ordered } \\
\text { Vermiculite } \\
\text { Muscovite } \\
\text { Saponite }\end{array}$ & $\begin{array}{l}69 \\
41 \\
27 \\
25 \\
21\end{array}$ \\
\hline R031i & $\begin{array}{l}\text { Palygorskite } \\
\text { Cuprite } \\
\text { Quartz } \\
\text { Pinakiolite } \\
\end{array}$ & $\begin{array}{l}49 \\
47 \\
37 \\
32 \\
\end{array}$ \\
\hline R032wp & $\begin{array}{l}\text { Quartz } \\
\text { Albite, Ca-rich, ordered } \\
\text { Microcline intermediate }\end{array}$ & $\begin{array}{l}65 \\
46 \\
35 \\
\end{array}$ \\
\hline R032wp_w_ABA & $\begin{array}{l}\text { Sodalite lithian } \\
\text { Pharmacosiderite } \\
\text { Cryptohalite } \\
\text { Westerveldite }\end{array}$ & $\begin{array}{l}33 \\
29 \\
26 \\
23\end{array}$ \\
\hline R033f_f & $\begin{array}{l}\text { Quartz } \\
\text { Albite, ordered } \\
\text { Dolomite, ferroan } \\
\text { Clinochlore, Fe- rich } \\
\text { Epidote } \\
\text { Phlogopite }\end{array}$ & $\begin{array}{l}59 \\
37 \\
29 \\
30 \\
26 \\
25\end{array}$ \\
\hline R033f_w & $\begin{array}{l}\text { Quartz } \\
\text { Birnessite (K-exchanged) } \\
\text { Ankerite } \\
\text { Kusachiite } \\
\text { Brucite } \\
\text { Epidote }\end{array}$ & $\begin{array}{l}68 \\
19 \\
22 \\
19 \\
28 \\
24\end{array}$ \\
\hline R034f_f & $\begin{array}{l}\text { Quartz } \\
\text { Albite low } \\
\text { Microcline intermediate } \\
\text { Ankerite } \\
\end{array}$ & $\begin{array}{l}70 \\
37 \\
16 \\
21\end{array}$ \\
\hline R034f_w & $\begin{array}{l}\text { Quartz } \\
\text { Albite low } \\
\text { Mercury chloride }\end{array}$ & $\begin{array}{l}74 \\
32 \\
21 \\
\end{array}$ \\
\hline
\end{tabular}




\begin{tabular}{|c|c|c|}
\hline Sample ID & Minerals present (XRD results) & Score* \\
\hline R035wp_f & $\begin{array}{l}\text { Quartz } \\
\text { Albite low } \\
\text { Ankerite } \\
\text { Biotite, Ti- rich } \\
\end{array}$ & $\begin{array}{l}69 \\
34 \\
25 \\
18\end{array}$ \\
\hline R035wp_w & $\begin{array}{l}\text { Quartz } \\
\text { Albite low } \\
\text { Ankerite } \\
\text { Jordanite } \\
\text { Mica } \\
\text { Eastonite (mica) }\end{array}$ & $\begin{array}{c}77 \\
24 \\
22 \\
9 \\
18 \\
14\end{array}$ \\
\hline R036i_f & $\begin{array}{l}\text { Quartz } \\
\text { Albite low } \\
\text { Fraipontite } \\
\text { Ankerite }\end{array}$ & $\begin{array}{l}59 \\
40 \\
29 \\
27\end{array}$ \\
\hline R036i_w & $\begin{array}{l}\text { Quartz } \\
\text { Albite low } \\
\text { Ankerite } \\
\text { Birnessite (K-exchanged) }\end{array}$ & $\begin{array}{l}67 \\
26 \\
23 \\
10\end{array}$ \\
\hline R037i & $\begin{array}{l}\text { Quartz } \\
\text { Jarosite } \\
\text { Hydrotalcite } \\
\text { Cerianite } \\
\text { Sylvite } \\
\text { Albite, disordered } \\
\text { Gypsum } \\
\end{array}$ & $\begin{array}{l}35 \\
49 \\
25 \\
32 \\
24 \\
14 \\
25 \\
\end{array}$ \\
\hline R038i_f & $\begin{array}{l}\text { Quartz } \\
\text { Epidote }\end{array}$ & $\begin{array}{l}67 \\
54\end{array}$ \\
\hline R038i_w & $\begin{array}{l}\text { Quartz } \\
\text { Albite low } \\
\text { Bemenite } \\
\text { Spessarite }\end{array}$ & $\begin{array}{l}66 \\
41 \\
24 \\
18\end{array}$ \\
\hline R039i_f & $\begin{array}{l}\text { Quartz } \\
\text { Albite, Ca-rich, ordered } \\
\text { Clinochlore, Fe-rich } \\
\text { Biotite }\end{array}$ & $\begin{array}{l}66 \\
38 \\
40 \\
28 \\
\end{array}$ \\
\hline R039i_w & $\begin{array}{l}\text { Quartz } \\
\text { Albite, Ca-rich, Ordered } \\
\text { Fraipontite } \\
\text { Annite } \\
\end{array}$ & $\begin{array}{l}68 \\
39 \\
28 \\
18 \\
\end{array}$ \\
\hline
\end{tabular}




\begin{tabular}{|c|c|c|}
\hline Sample ID & Minerals present (XRD results) & Score* \\
\hline R040i & $\begin{array}{l}\text { Quartz low } \\
\text { Albite low } \\
\text { Giniite }\end{array}$ & $\begin{array}{l}74 \\
23 \\
26\end{array}$ \\
\hline R040i_f & $\begin{array}{l}\text { Quartz } \\
\text { Anorthite sodian } \\
\text { Dickite } \\
\text { Fraipontite } \\
\end{array}$ & $\begin{array}{l}64 \\
40 \\
21 \\
28\end{array}$ \\
\hline R040i_w & $\begin{array}{l}\text { Quartz } \\
\text { Fraipontite } \\
\text { Albite low } \\
\end{array}$ & $\begin{array}{l}72 \\
19 \\
26 \\
\end{array}$ \\
\hline R041i_f & $\begin{array}{l}\text { Albite, Ca-rich, ordered } \\
\text { Quartz } \\
\text { Vermiculite } \\
\text { Dickite }\end{array}$ & $\begin{array}{l}64 \\
50 \\
30 \\
15\end{array}$ \\
\hline R041i_w & $\begin{array}{l}\text { Quartz } \\
\text { Albite, Ca-rich, ordered } \\
\text { Brucite } \\
\text { Jordanite } \\
\text { Gobbinsite }\end{array}$ & $\begin{array}{c}74 \\
39 \\
26 \\
10 \\
7\end{array}$ \\
\hline R042i_f & $\begin{array}{l}\text { Quartz low } \\
\text { Albite, Ca-rich, ordered } \\
\text { Gismondine }\end{array}$ & $\begin{array}{l}69 \\
44 \\
33 \\
\end{array}$ \\
\hline R042i_w & $\begin{array}{l}\text { Quartz } \\
\text { Albite, Ca-rich, ordered } \\
\text { Eastonite (mica) }\end{array}$ & $\begin{array}{l}76 \\
34 \\
22 \\
\end{array}$ \\
\hline R043wp_f & $\begin{array}{l}\text { Quartz } \\
\text { Albite low } \\
\text { Microcline intermediate } \\
\text { Zinnwaldite }\end{array}$ & $\begin{array}{l}62 \\
58 \\
22 \\
19\end{array}$ \\
\hline R043wp_w & $\begin{array}{l}\text { Quartz } \\
\text { Kusachiite } \\
\text { Goethite } \\
\text { Arsenopyrite } \\
\text { Chalcocite, high } \\
\text { Iron sulfide } \\
\end{array}$ & $\begin{array}{l}65 \\
21 \\
20 \\
16 \\
15 \\
11\end{array}$ \\
\hline R044i_f & $\begin{array}{l}\text { Quartz } \\
\text { Albite low } \\
\text { Lindackerite }\end{array}$ & $\begin{array}{l}70 \\
35 \\
13\end{array}$ \\
\hline
\end{tabular}




\begin{tabular}{|c|c|c|}
\hline Sample ID & Minerals present (XRD results) & Score* \\
\hline R044i_w & $\begin{array}{l}\text { Goethite } \\
\text { Quartz } \\
\text { Albite, Ca-rich, ordered }\end{array}$ & $\begin{array}{l}38 \\
27 \\
16\end{array}$ \\
\hline R045f_f & $\begin{array}{l}\text { Quartz } \\
\text { Albite, Ca-rich, ordered } \\
\text { Ankerite } \\
\text { Phlogopite, Fe-rich } \\
\text { Fraipontite }\end{array}$ & $\begin{array}{l}65 \\
43 \\
27 \\
28 \\
24 \\
\end{array}$ \\
\hline R045f_w & $\begin{array}{l}\text { Quartz } \\
\text { Hematite } \\
\text { Ankerite } \\
\text { Albite, ca-rich, ordered } \\
\text { Fraipontite } \\
\text { Phlogopite, Fe-rich } \\
\end{array}$ & $\begin{array}{l}70 \\
36 \\
30 \\
29 \\
17 \\
11\end{array}$ \\
\hline R046i_f & $\begin{array}{l}\text { Quartz } \\
\text { Albite low } \\
\text { Microcline, intermediate } \\
\text { Tephorite, Ca-rich } \\
\text { Albite } \\
\text { Siderophyllite lithian } \\
\end{array}$ & $\begin{array}{l}65 \\
53 \\
31 \\
26 \\
28 \\
19\end{array}$ \\
\hline R046i_w & \begin{tabular}{|l} 
Quartz \\
Albite low \\
Microcline, intermediate \\
Biotite \\
\end{tabular} & $\begin{array}{l}70 \\
33 \\
28 \\
13 \\
\end{array}$ \\
\hline R047f_f & $\begin{array}{l}\text { Quartz } \\
\text { Fraipontite } \\
\text { Anorthite sodian, intermediate }\end{array}$ & $\begin{array}{l}72 \\
41 \\
58 \\
\end{array}$ \\
\hline R047f_w & $\begin{array}{l}\text { Quartz } \\
\text { Hematite } \\
\text { Kusachiite }\end{array}$ & $\begin{array}{l}60 \\
37 \\
16\end{array}$ \\
\hline R048i_f & $\begin{array}{l}\text { Quartz } \\
\text { Albite, Ca-rich, ordered }\end{array}$ & $\begin{array}{r}71 \\
33 \\
\end{array}$ \\
\hline R048i_w & $\begin{array}{l}\text { Quartz } \\
\text { Albite, Ca-rich, ordered } \\
\text { Montomorillonite }\end{array}$ & $\begin{array}{l}69 \\
26 \\
13\end{array}$ \\
\hline R049i_porphyry & $\begin{array}{l}\text { Quartz } \\
\text { Mgriite }\end{array}$ & $\begin{array}{l}78 \\
13\end{array}$ \\
\hline
\end{tabular}




\begin{tabular}{|c|c|c|}
\hline Sample ID & Minerals present (XRD results) & Score* \\
\hline R049i_matrix & $\begin{array}{l}\text { Quartz } \\
\text { Albite low } \\
\text { Ankerite } \\
\text { Biotite } \\
\text { Birnessite (K-exchanged) } \\
\text { Epidote }\end{array}$ & $\begin{array}{l}67 \\
34 \\
28 \\
28 \\
21 \\
37\end{array}$ \\
\hline R050f_porphyry & $\begin{array}{l}\text { Quartz } \\
\text { Albite, Ca-rich, ordered } \\
\text { Epidote } \\
\text { Muscovite }\end{array}$ & $\begin{array}{l}72 \\
28 \\
31 \\
11\end{array}$ \\
\hline R050f_matrix & $\begin{array}{l}\text { Quartz } \\
\text { Albite, Ca-rich, ordered } \\
\text { Birnessite (K-exchanged) } \\
\text { Phlogopite, Fe-rich } \\
\end{array}$ & $\begin{array}{l}67 \\
39 \\
26 \\
36\end{array}$ \\
\hline R051i_f & $\begin{array}{l}\text { Quartz } \\
\text { Albite, Ca-rich, ordered } \\
\text { Birnessite (K-exchanged) }\end{array}$ & $\begin{array}{l}79 \\
34 \\
12 \\
\end{array}$ \\
\hline R051i_w & $\begin{array}{l}\text { Quartz } \\
\text { Albite, Ca-rich, ordered } \\
\text { Faujasite (Ce-exchanged) }\end{array}$ & $\begin{array}{l}77 \\
36 \\
26 \\
\end{array}$ \\
\hline R052f_f & $\begin{array}{l}\text { Quartz } \\
\text { Albite low } \\
\text { Phlogopite, Fe-rich } \\
\text { Eastonite (mica) } \\
\end{array}$ & $\begin{array}{l}70 \\
32 \\
26 \\
22 \\
\end{array}$ \\
\hline R053i_f & $\begin{array}{l}\text { Quartz } \\
\text { Albite, Ca-rich, ordered } \\
\text { Phlogopite, Fe-rich } \\
\text { Birnessite (K-exchanged) }\end{array}$ & $\begin{array}{l}73 \\
33 \\
31 \\
17\end{array}$ \\
\hline R054i_f & $\begin{array}{l}\text { Quartz } \\
\text { Phlogopite, Fe-rich } \\
\text { Albite, Ca-rich, ordered }\end{array}$ & $\begin{array}{l}72 \\
33 \\
27 \\
\end{array}$ \\
\hline R055i_f & $\begin{array}{l}\text { Quartz } \\
\text { Biotite } \\
\text { Albite, Ca-rich, ordered } \\
\text { Bearsite }\end{array}$ & $\begin{array}{l}69 \\
38 \\
24 \\
13\end{array}$ \\
\hline R055i_w & $\begin{array}{l}\text { Quartz } \\
\text { Birnessite } \\
\text { Albite low } \\
\text { Schoepite }\end{array}$ & $\begin{array}{l}66 \\
25 \\
22 \\
19\end{array}$ \\
\hline
\end{tabular}




\begin{tabular}{|c|c|c|}
\hline Sample ID & Minerals present (XRD results) & Score* \\
\hline R056f_f & $\begin{array}{l}\text { Quartz } \\
\text { Albite low } \\
\text { Dolomite, ferroan } \\
\text { Biotite }\end{array}$ & $\begin{array}{l}69 \\
27 \\
17 \\
12\end{array}$ \\
\hline R056f_w & $\begin{array}{l}\text { Quartz } \\
\text { Kusachiite } \\
\text { Colusite } \\
\text { Goethite } \\
\text { Krautite } \\
\text { Asselbornite }\end{array}$ & $\begin{array}{c}53 \\
19 \\
13 \\
10 \\
6 \\
12 \\
\end{array}$ \\
\hline R057i_f & $\begin{array}{l}\text { Quartz } \\
\text { Phlogopite, Fe-rich } \\
\text { Albite, Ca-rich, ordered }\end{array}$ & $\begin{array}{l}62 \\
15 \\
16 \\
\end{array}$ \\
\hline R057i_w & $\begin{array}{l}\text { Quartz } \\
\text { Albite, Ca-rich, ordered } \\
\text { Phlogopite, Fe-rich }\end{array}$ & $\begin{array}{l}77 \\
21 \\
19 \\
\end{array}$ \\
\hline R058i_f & $\begin{array}{l}\text { Quartz } \\
\text { Fraipontite } \\
\text { Kusachiite } \\
\end{array}$ & $\begin{array}{l}65 \\
40 \\
20\end{array}$ \\
\hline R058i_w & $\begin{array}{l}\text { Quartz } \\
\text { Clinochlore, Fe- rich } \\
\text { Calcite magnesian } \\
\end{array}$ & $\begin{array}{l}71 \\
55 \\
20 \\
\end{array}$ \\
\hline R059i_f & $\begin{array}{l}\text { Quartz } \\
\text { Albite low } \\
\text { Biotite } \\
\end{array}$ & $\begin{array}{l}75 \\
24 \\
15 \\
\end{array}$ \\
\hline R060i_f & $\begin{array}{l}\text { Quartz } \\
\text { Albite, Ca-rich, ordered } \\
\text { Microperthite }\end{array}$ & $\begin{array}{l}68 \\
47 \\
34 \\
\end{array}$ \\
\hline R061i_f & $\begin{array}{l}\text { Quartz } \\
\text { Albite low } \\
\text { Phlogopite, Fe-rich }\end{array}$ & $\begin{array}{l}76 \\
30 \\
12 \\
\end{array}$ \\
\hline R061i_w & \begin{tabular}{|l|} 
Quartz \\
Phlogopite \\
\end{tabular} & $\begin{array}{c}39 \\
7 \\
\end{array}$ \\
\hline R062i_f & $\begin{array}{l}\text { Quartz } \\
\text { Albite low } \\
\text { Biotite } \\
\end{array}$ & $\begin{array}{l}73 \\
40 \\
21 \\
\end{array}$ \\
\hline R063i_f & $\begin{array}{l}\text { Quartz } \\
\text { Albite calcian low } \\
\text { Ferropargasite }\end{array}$ & $\begin{array}{l}64 \\
50 \\
29\end{array}$ \\
\hline
\end{tabular}




\begin{tabular}{|c|c|c|}
\hline Sample ID & Minerals present (XRD results) & Score* \\
\hline R064i_f & $\begin{array}{l}\text { Moissanite } \\
\text { Quartz } \\
\text { Albite, ordered }\end{array}$ & $\begin{array}{l}65 \\
61 \\
44\end{array}$ \\
\hline R065i_f & $\begin{array}{l}\text { Quartz } \\
\text { Anorthite, Na-rich, intermediate } \\
\text { Moissanite } \\
\text { Phlogopite, Fe-rich } \\
\text { Birnessite (K-exchanged) } \\
\end{array}$ & $\begin{array}{l}49 \\
35 \\
20 \\
40 \\
16\end{array}$ \\
\hline R066i_f & $\begin{array}{l}\text { Quartz } \\
\text { Albite, Ca-rich, ordered } \\
\text { Dolomite, ferroan } \\
\text { Phlogopite, Fe-rich }\end{array}$ & $\begin{array}{l}67 \\
38 \\
31 \\
26\end{array}$ \\
\hline R067i_f & $\begin{array}{l}\text { Quartz } \\
\text { Albite calcian low } \\
\text { Phlogopite, Fe-rich }\end{array}$ & $\begin{array}{l}72 \\
31 \\
34 \\
\end{array}$ \\
\hline Mr001_f & \begin{tabular}{|l|} 
Quartz \\
Albite low \\
\end{tabular} & $\begin{array}{l}67 \\
34 \\
\end{array}$ \\
\hline Mr001_w & $\begin{array}{l}\text { Quartz } \\
\text { Albite low } \\
\text { Illite } \\
\text { Carphosiderite } \\
\text { Eastonite (mica) } \\
\end{array}$ & $\begin{array}{l}65 \\
28 \\
20 \\
26 \\
26\end{array}$ \\
\hline Mr001_recentweathering? & $\begin{array}{l}\text { Quartz } \\
\text { Kusachiite } \\
\text { Goethite } \\
\text { Pharmacosiderite } \\
\text { Cristobalite } \\
\end{array}$ & $\begin{array}{l}70 \\
26 \\
19 \\
11 \\
13\end{array}$ \\
\hline Mr002_hydrothermal? & $\begin{array}{l}\text { Sodiumpharmacosiderite } \\
\text { Arseniosiderite } \\
\text { Yukonite }\end{array}$ & $\begin{array}{l}47 \\
38 \\
31 \\
\end{array}$ \\
\hline Mr002_f & $\begin{array}{l}\text { Quartz } \\
\text { Moissanite } \\
\text { Albite, Ca-rich, ordered } \\
\text { Meixnerite } \\
\text { Phlogopite, Fe-rich }\end{array}$ & $\begin{array}{l}63 \\
42 \\
35 \\
32 \\
24\end{array}$ \\
\hline Mr002_w & $\begin{array}{l}\text { Quartz } \\
\text { Vanuralite } \\
\text { Albite low } \\
\text { Jachymovite }\end{array}$ & $\begin{array}{l}61 \\
25 \\
20 \\
20\end{array}$ \\
\hline
\end{tabular}




\begin{tabular}{|l|l|c|}
\hline Sample ID & Minerals present (XRD results) & Score* \\
\hline Mr003_f & Quartz & 67 \\
& Anorthite sodian & 38 \\
& Lindackerite & 15 \\
& Cordierite (dehydrated, Ar- & \\
& bearing) & 9 \\
\hline Mr003_w & Quartz & 64 \\
& Albite calcian low & 48 \\
& Faujasite (Ag-exchanged) & 26 \\
\hline Mr004_f & Quartz & 66 \\
& Albite low & 44 \\
& Faujasite (Ag-exchanged) & 16 \\
\hline Mr004_w & Quartz & 51 \\
& Albite low & 30 \\
& Eastonite (mica) & 24 \\
\hline Mr005 & Quartz & 44 \\
& Fraipontite & 37 \\
& Jachymovite & 19 \\
& Faujasite (Ag-exchanged) & 22 \\
\hline Mr006_f & Quartz & 64 \\
& Albite low & 34 \\
& Birnessite (K-exchanged) & 23 \\
& Natrojarosite & 32 \\
& Faujasite-Na & 16 \\
\hline Mk005 & Quartz & 64 \\
& Natrojarosite & 42 \\
& Albite low & 31 \\
& Birnessite (K-exchanged) & 30 \\
\hline Mr006_w & Natrojarosite & 70 \\
\hline Mk002 & Natrojarosite & 58 \\
& Plumbojarosite & 30 \\
& Tellurium & 23 \\
& Iron sulfide & 16 \\
& Birnessite (K-exchanged) & 15 \\
\hline Mk003 & Gypsum & 61 \\
& Quartz & 50 \\
& Albite low & 18 \\
\hline & Arsenopyrite & Quartz \\
\hline
\end{tabular}




\begin{tabular}{|l|l|c|}
\hline Sample ID & Minerals present (XRD results) & Score* \\
\hline Mk006 & Gypsum & 56 \\
& Natroalunite & 38 \\
& Quartz & 36 \\
& Aluminite & 29 \\
& Uranopilite & 16 \\
\hline
\end{tabular}

* Identified minerals were assigned a score from 0 - 100 by HighScore PANalytical Software, where 100 is a perfect match with X-ray spectra from the JCPDS reference database. 
APPENDIX G: Sample photos

R001i

\section{Rooli}

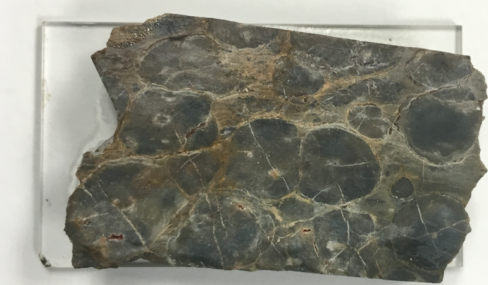

_ |||||||||||||||||||||||||||||||||||||||||||||||

$\begin{array}{llllll}0 & 1 \mathrm{~cm} & 2 & 3 & 4 & 5\end{array}$
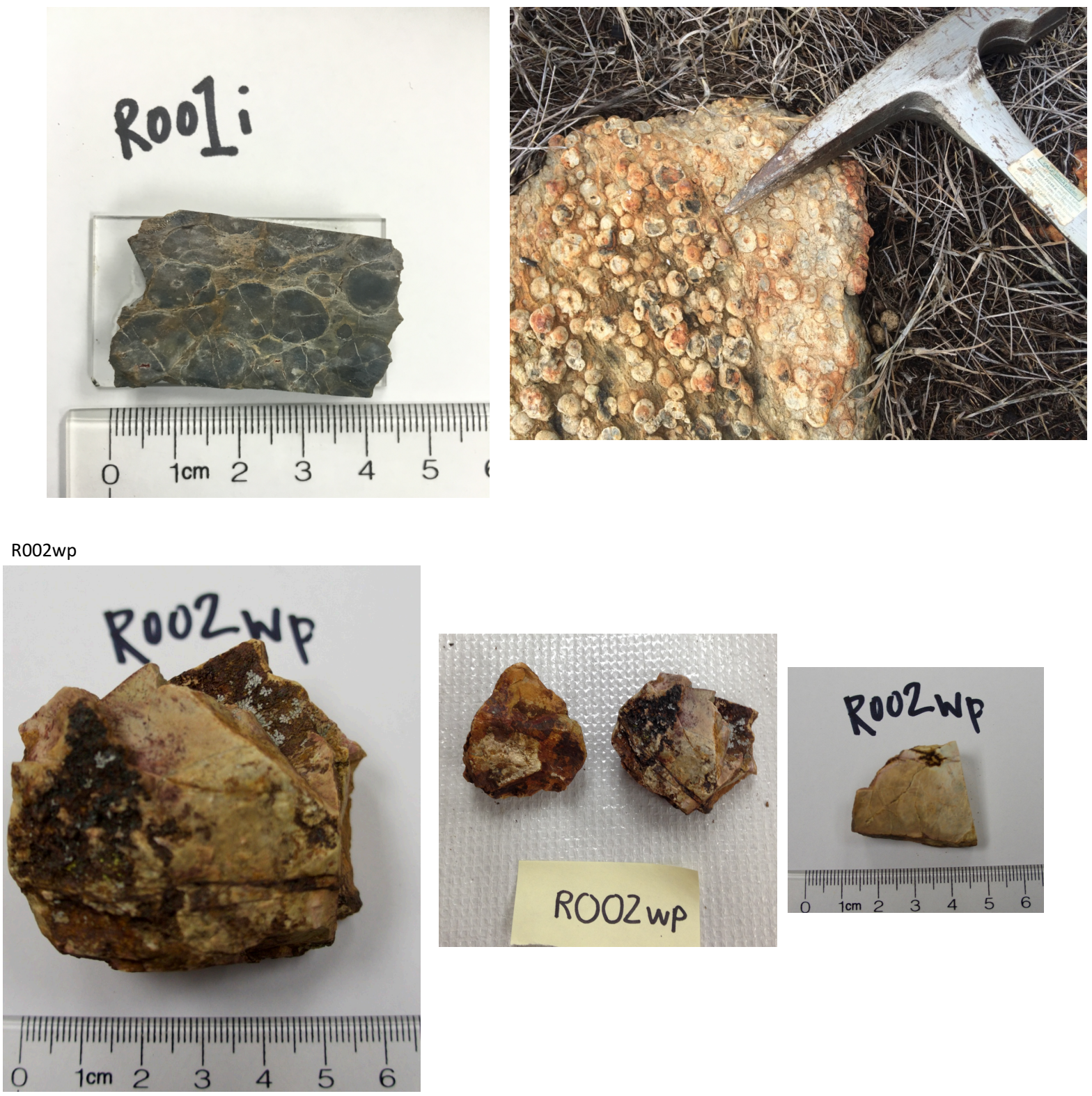

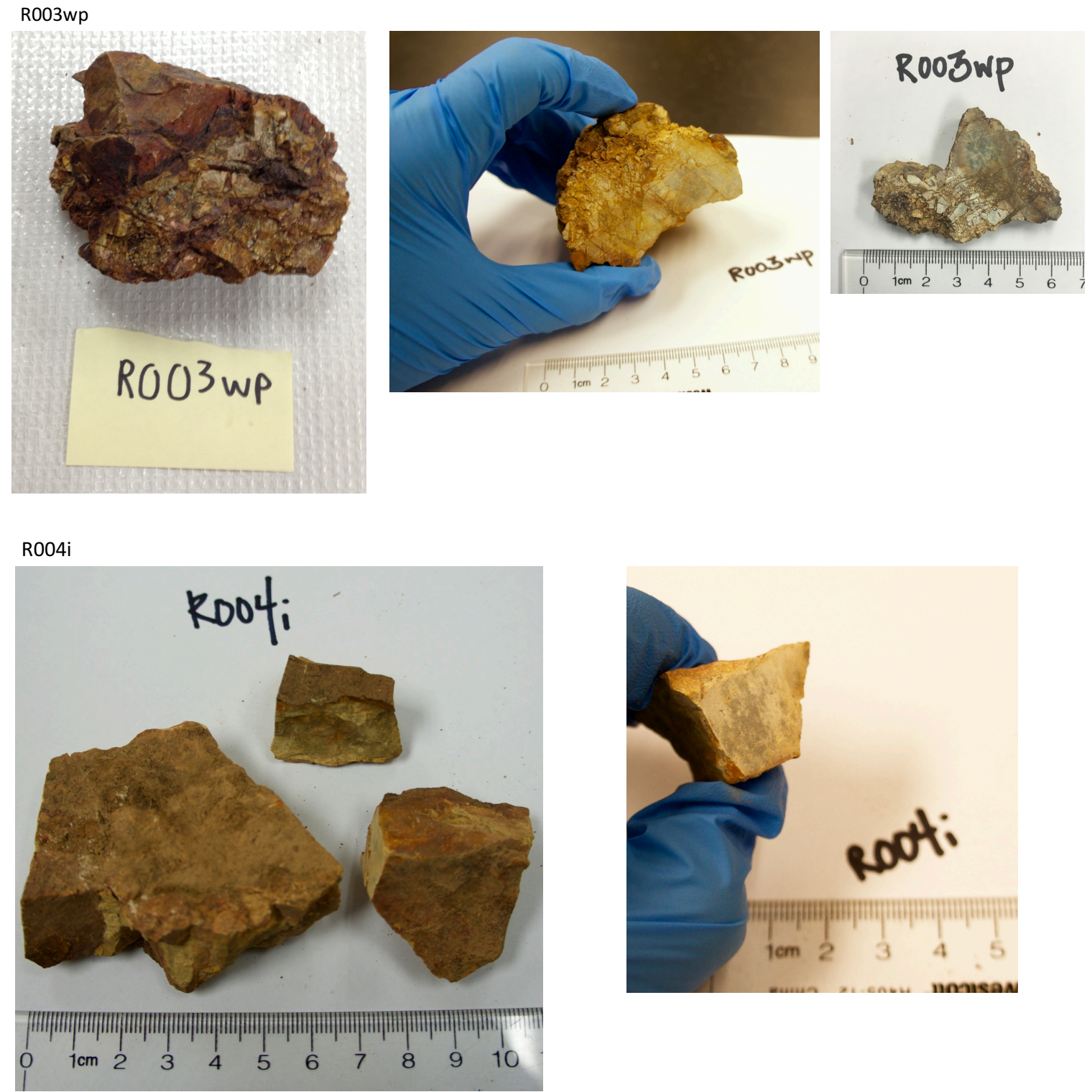

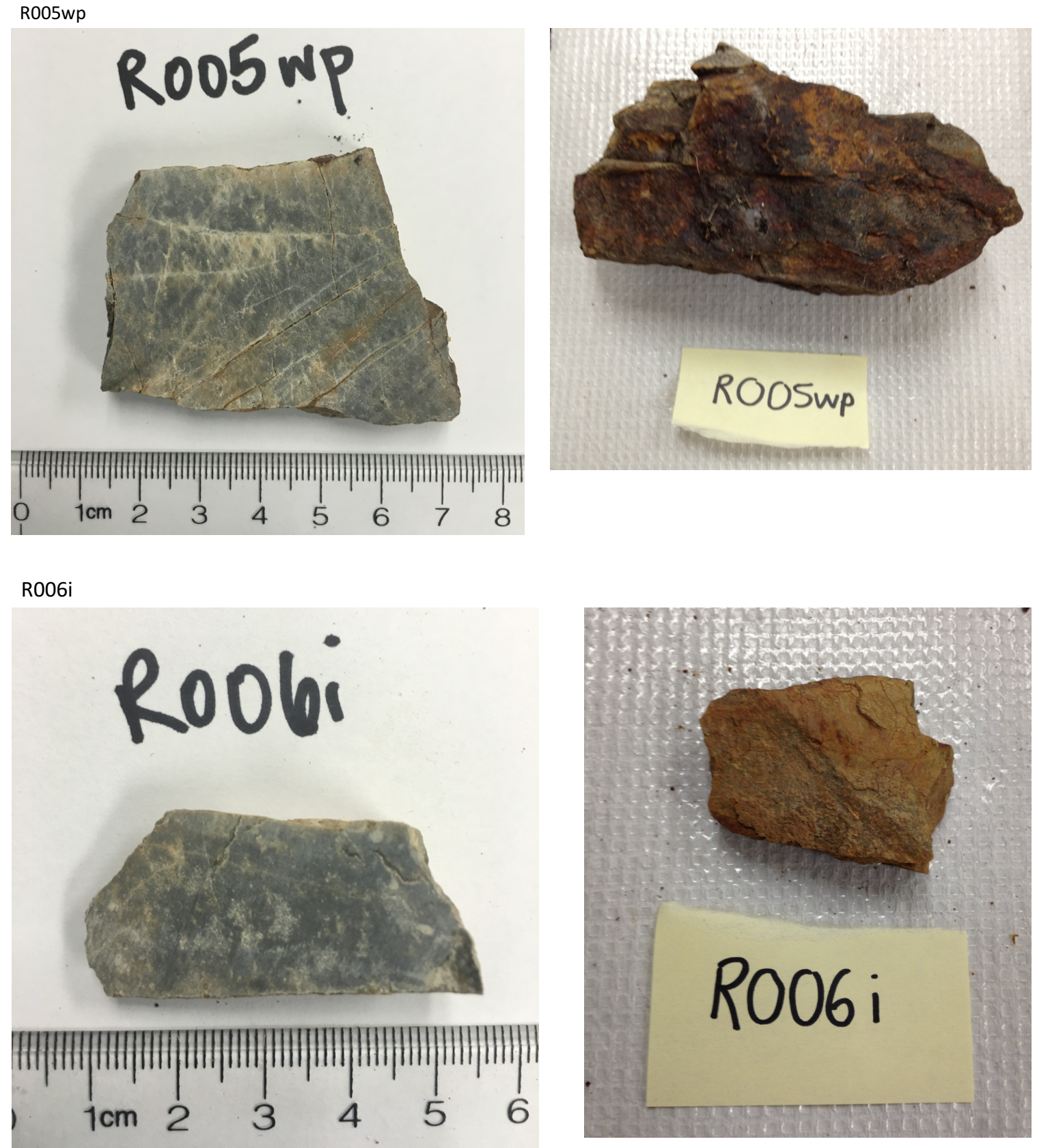
R007wp

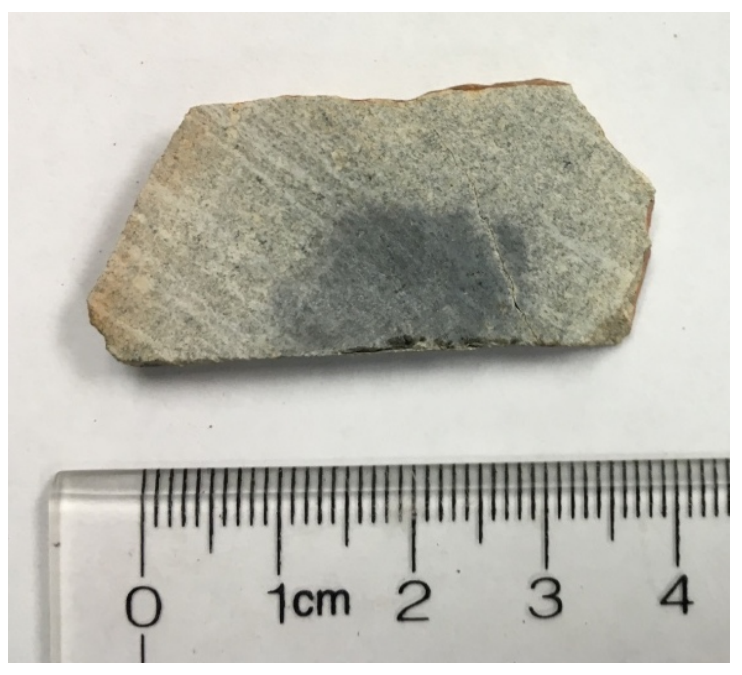

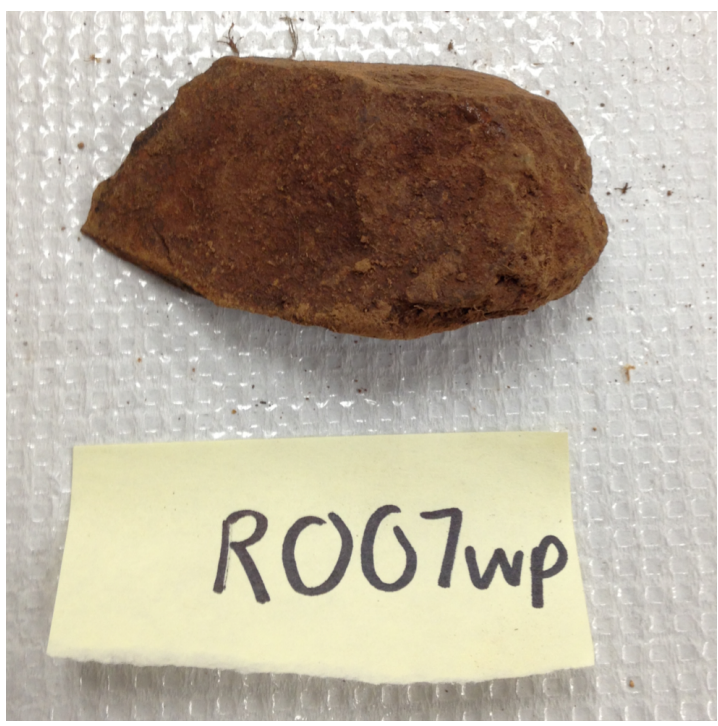

R008f
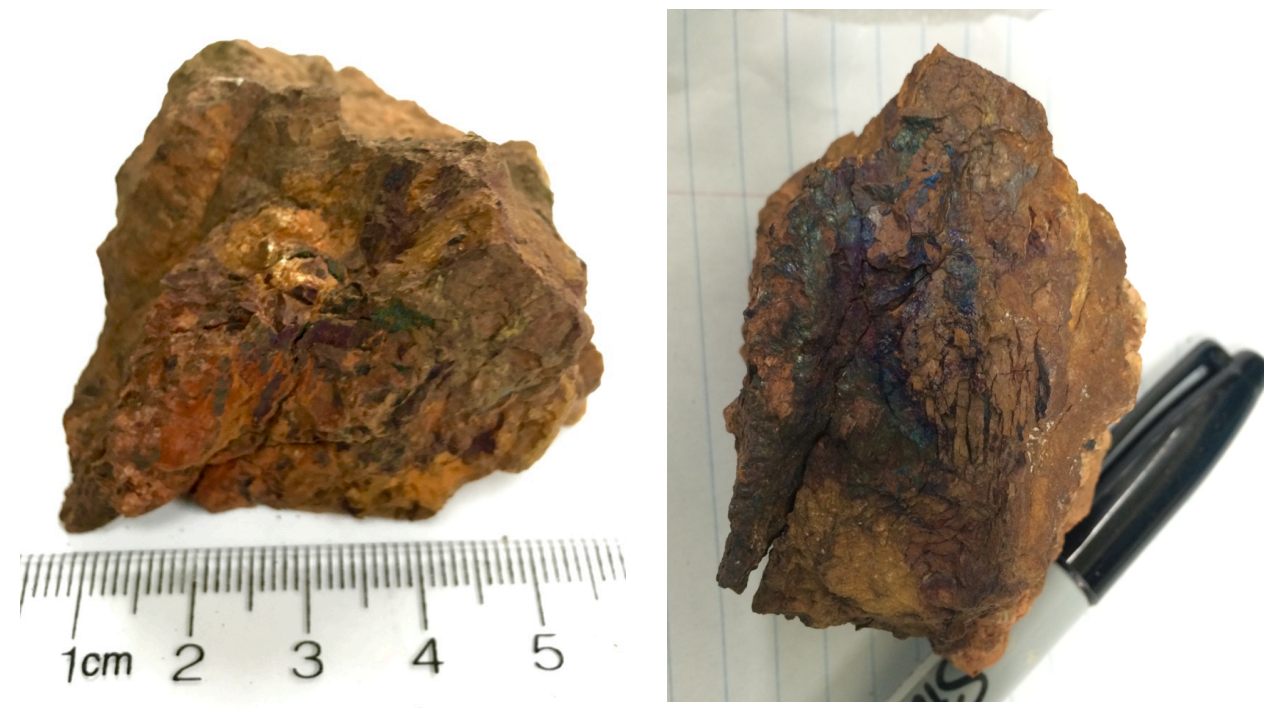

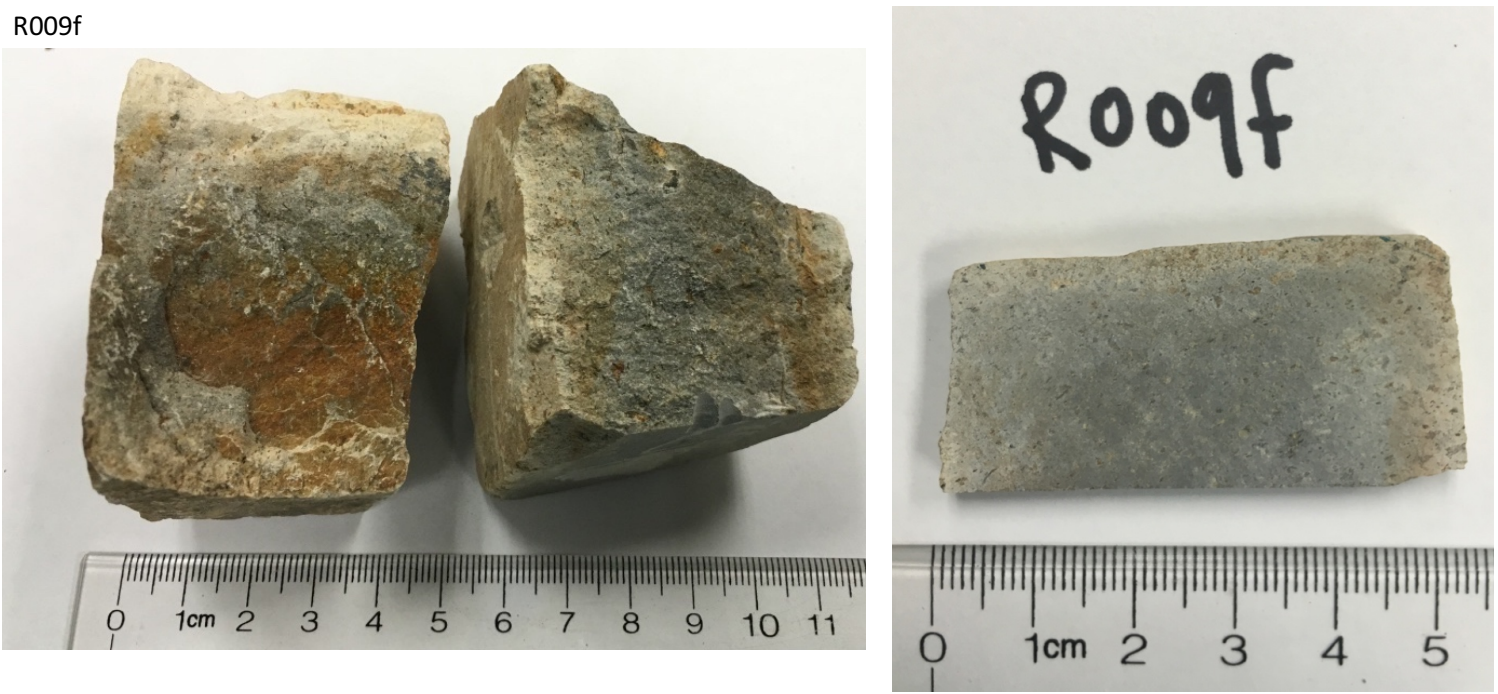

R010f
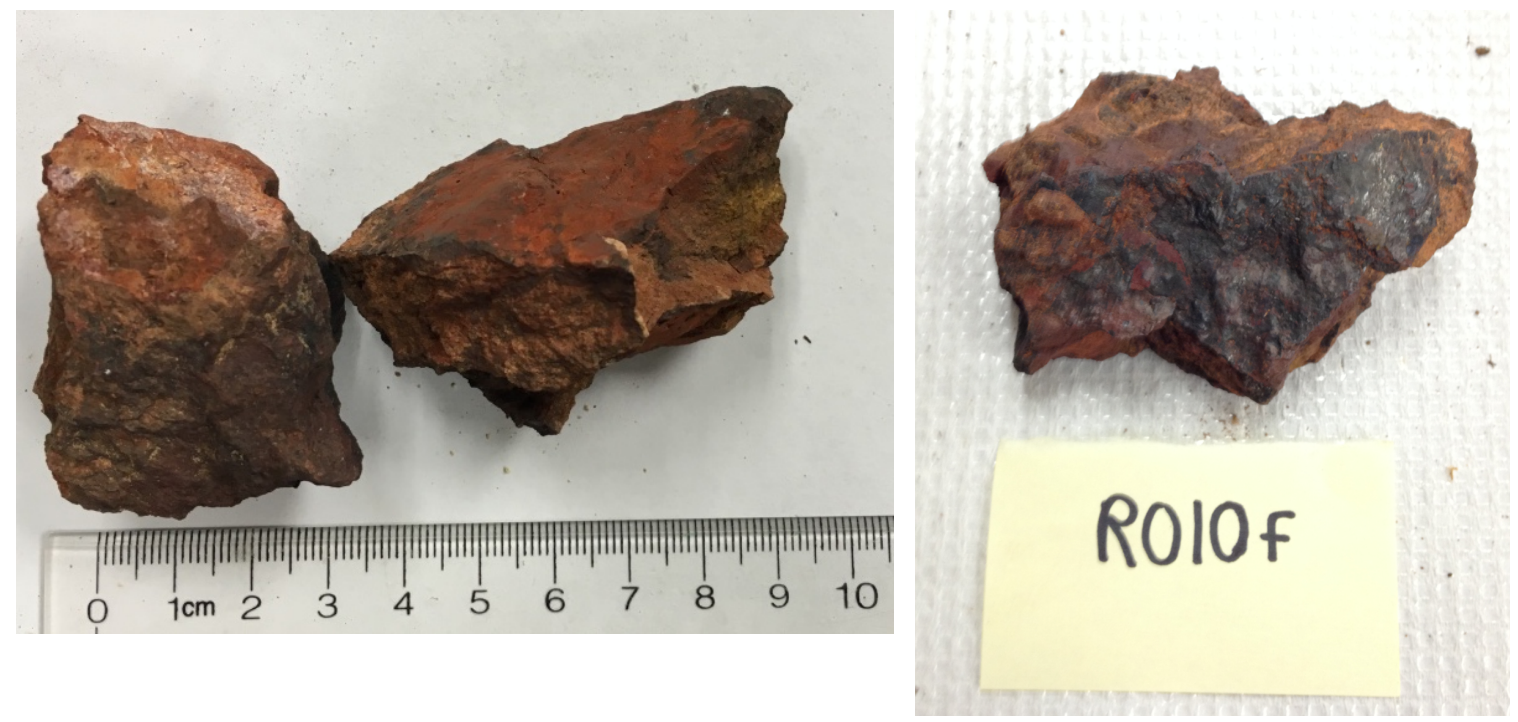

R011i

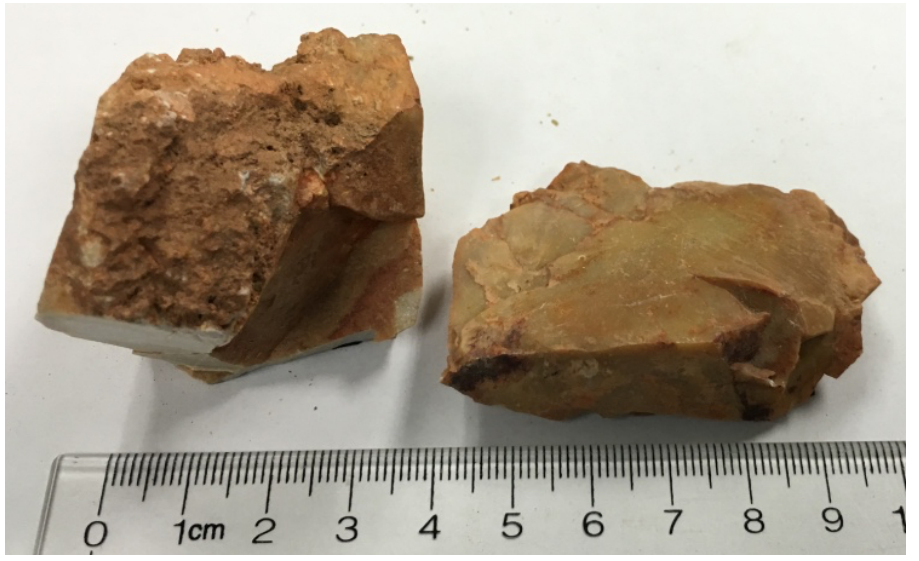



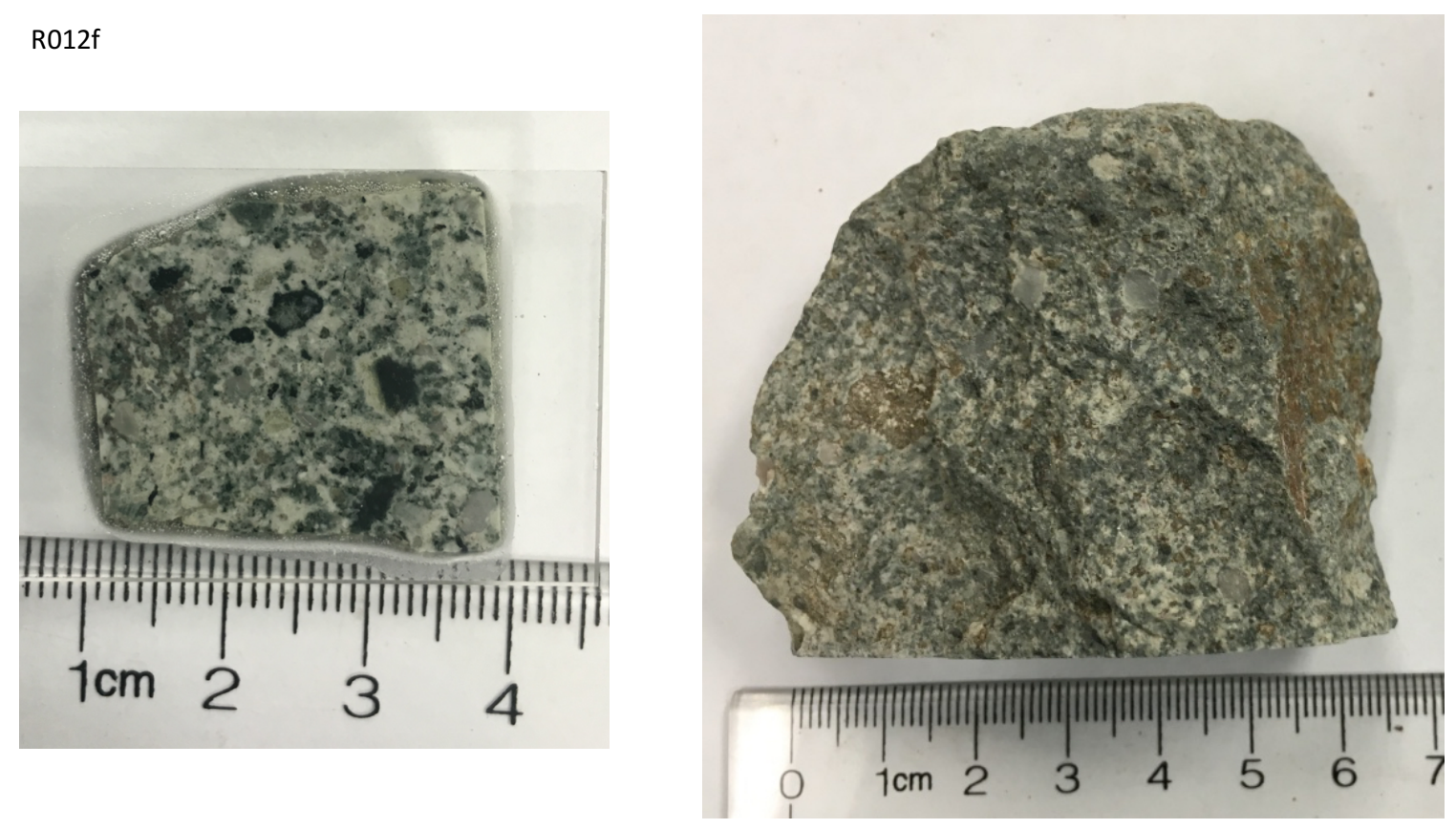

R013f

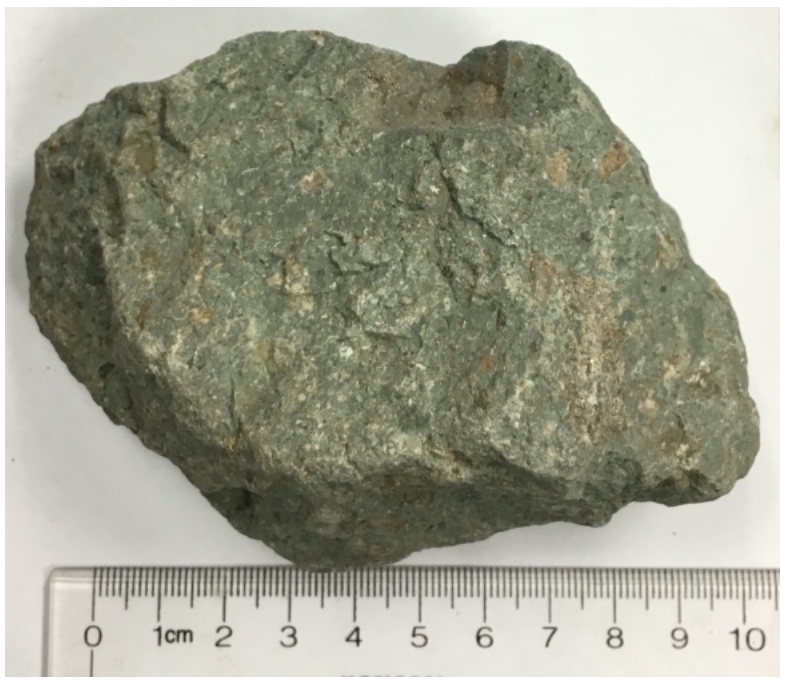



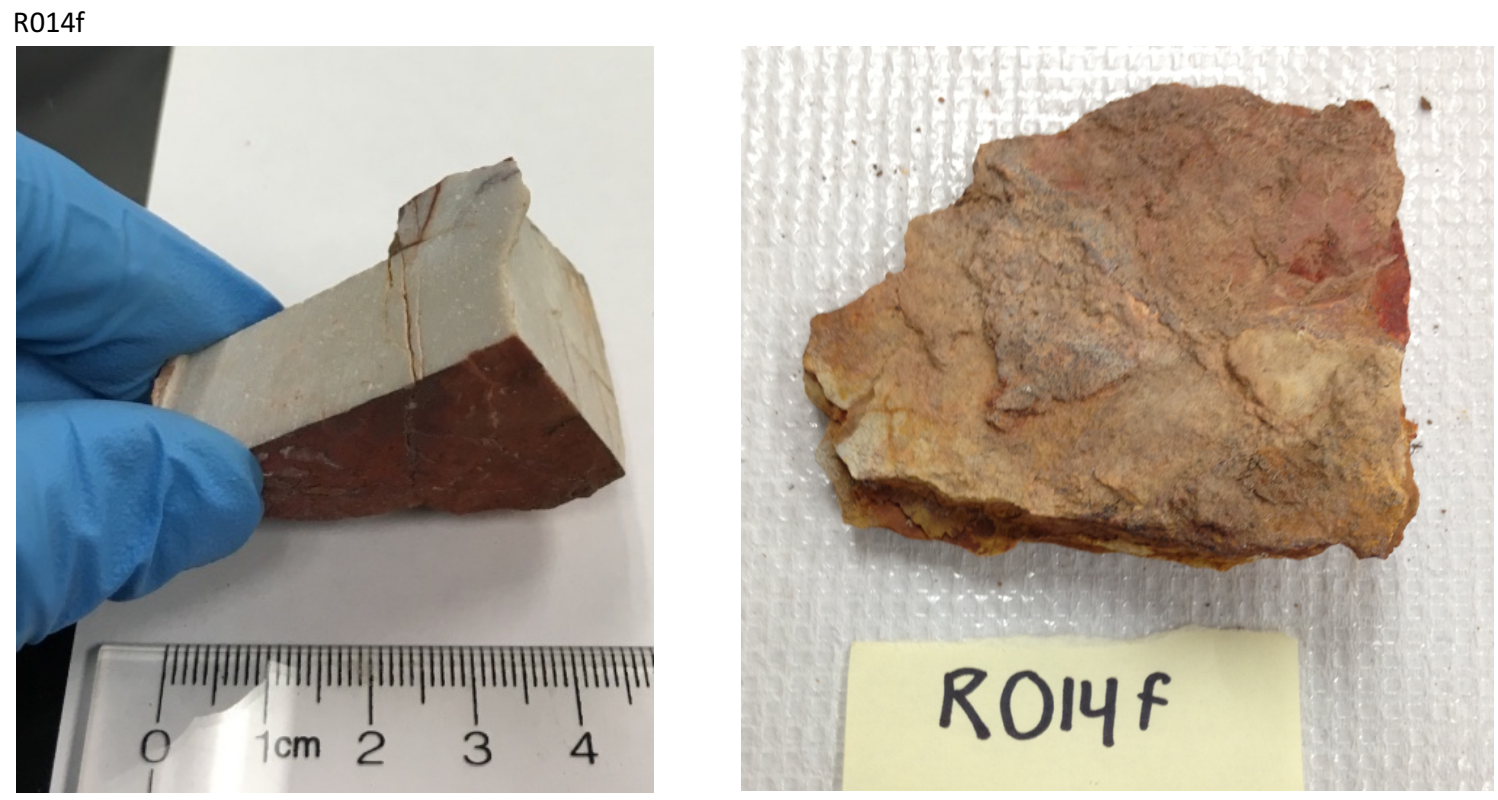

R015f
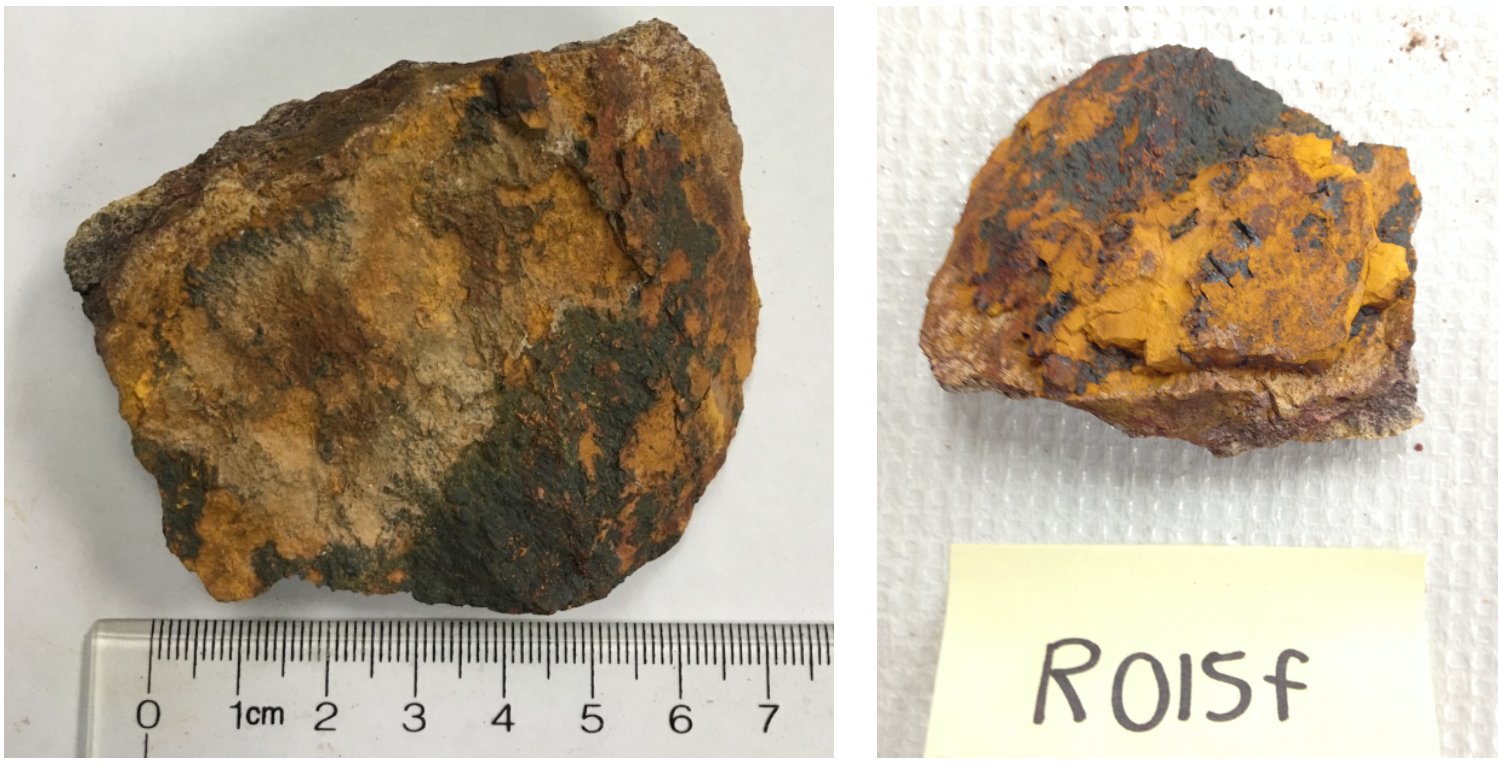


\section{R016f}

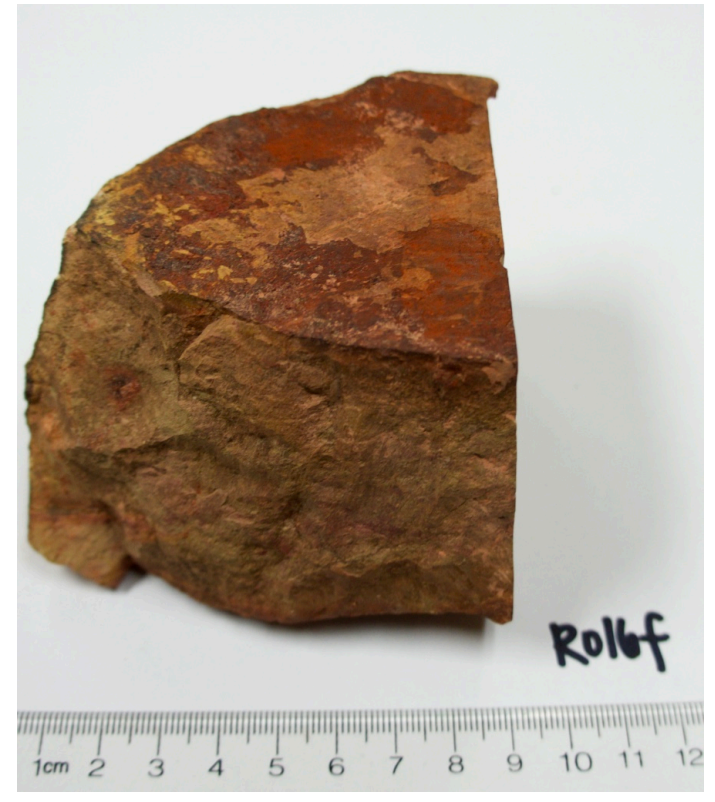

R017f

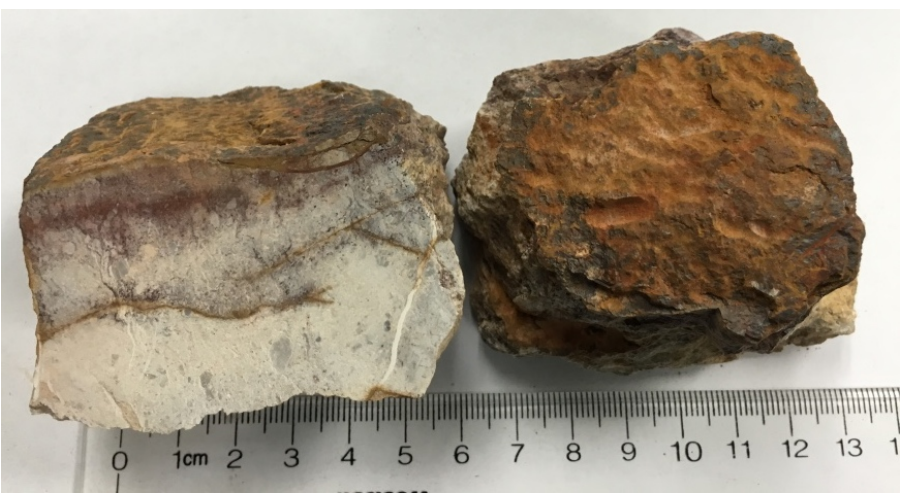

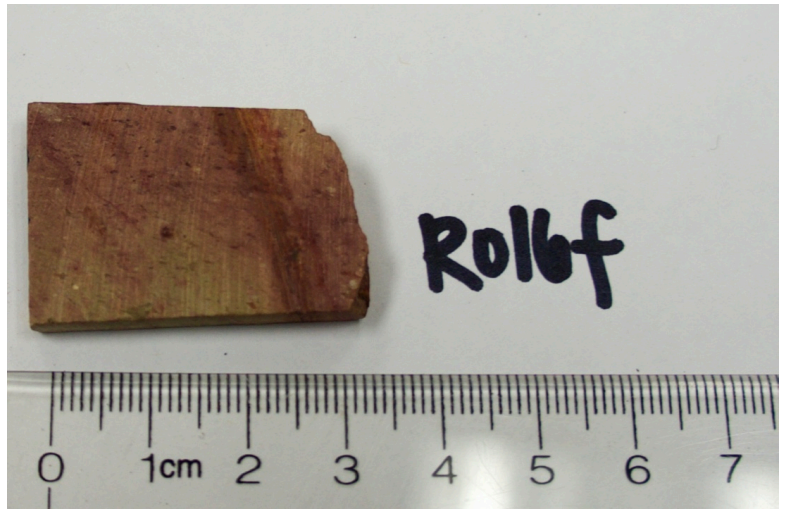

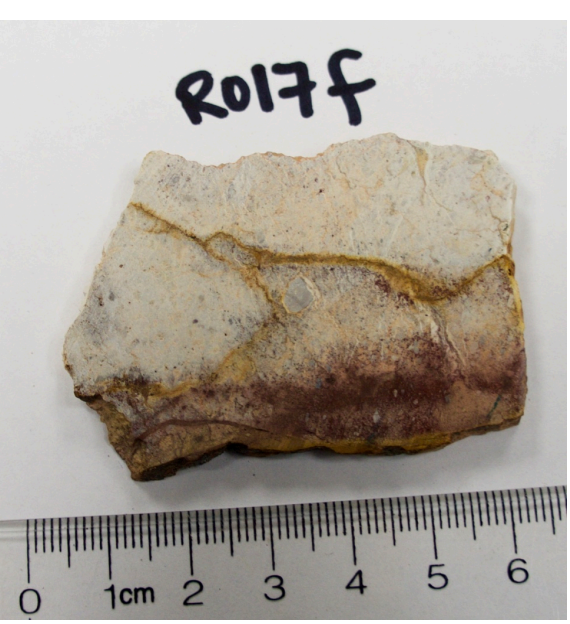



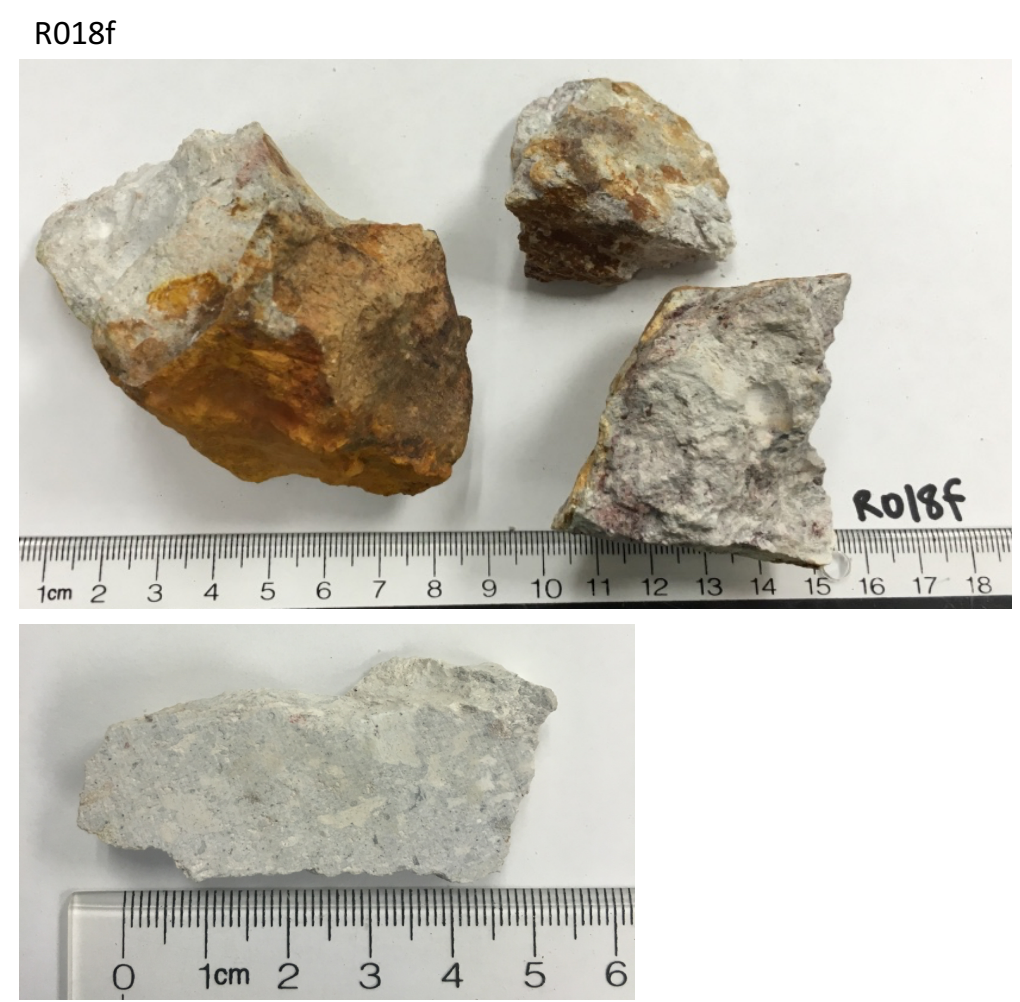

R019f

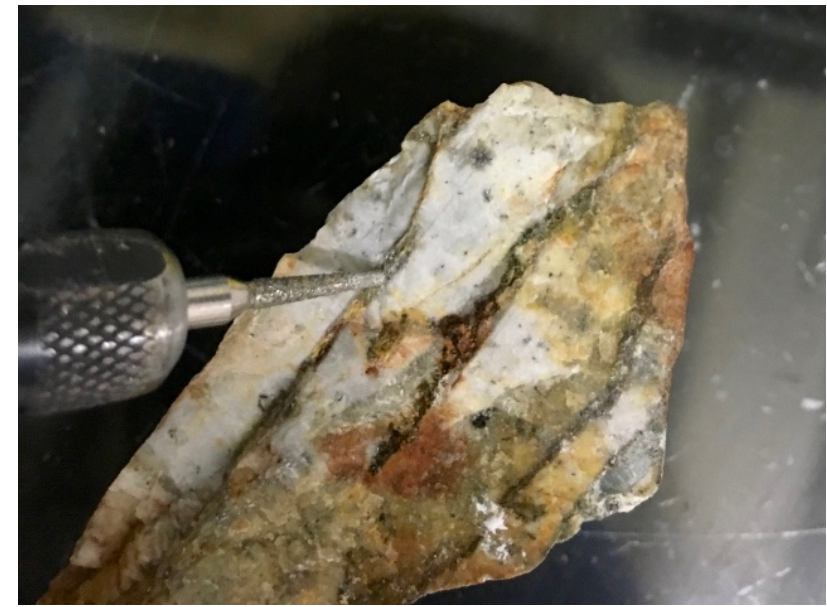



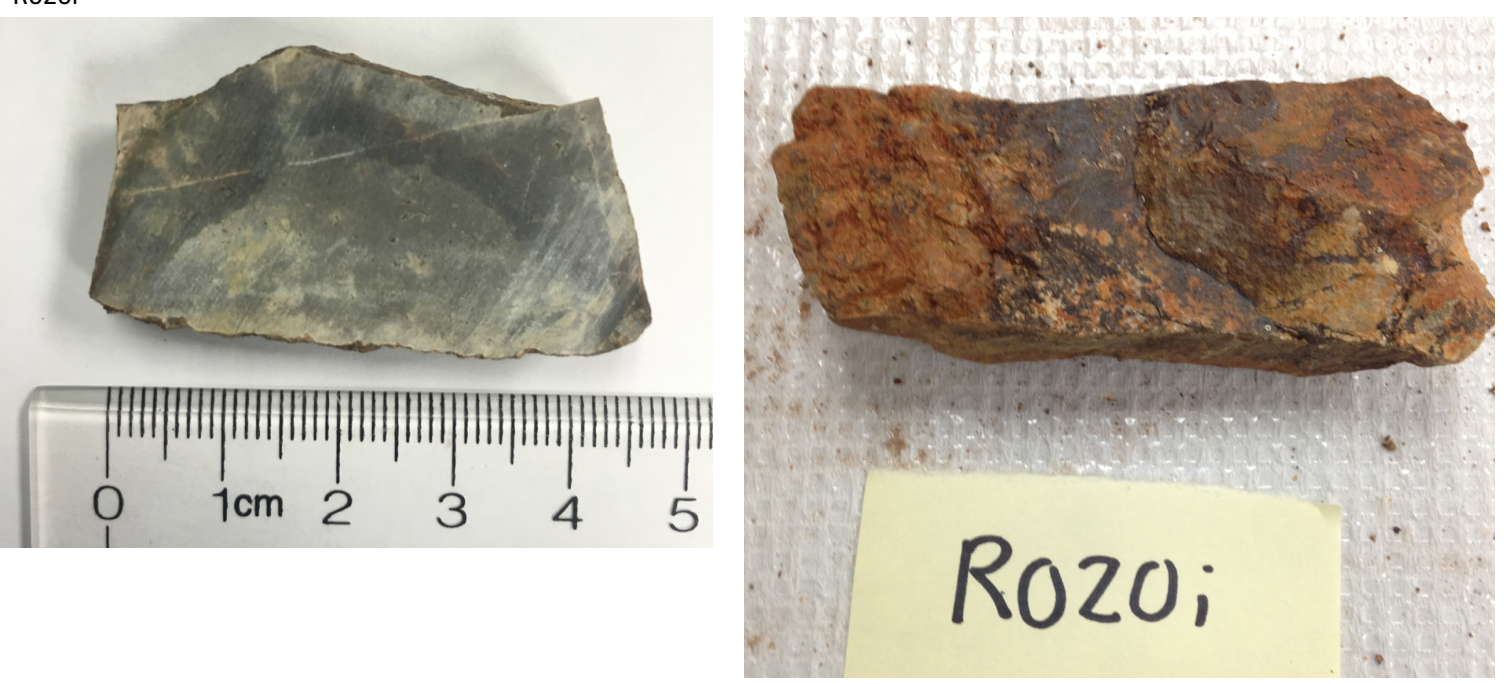

R021i
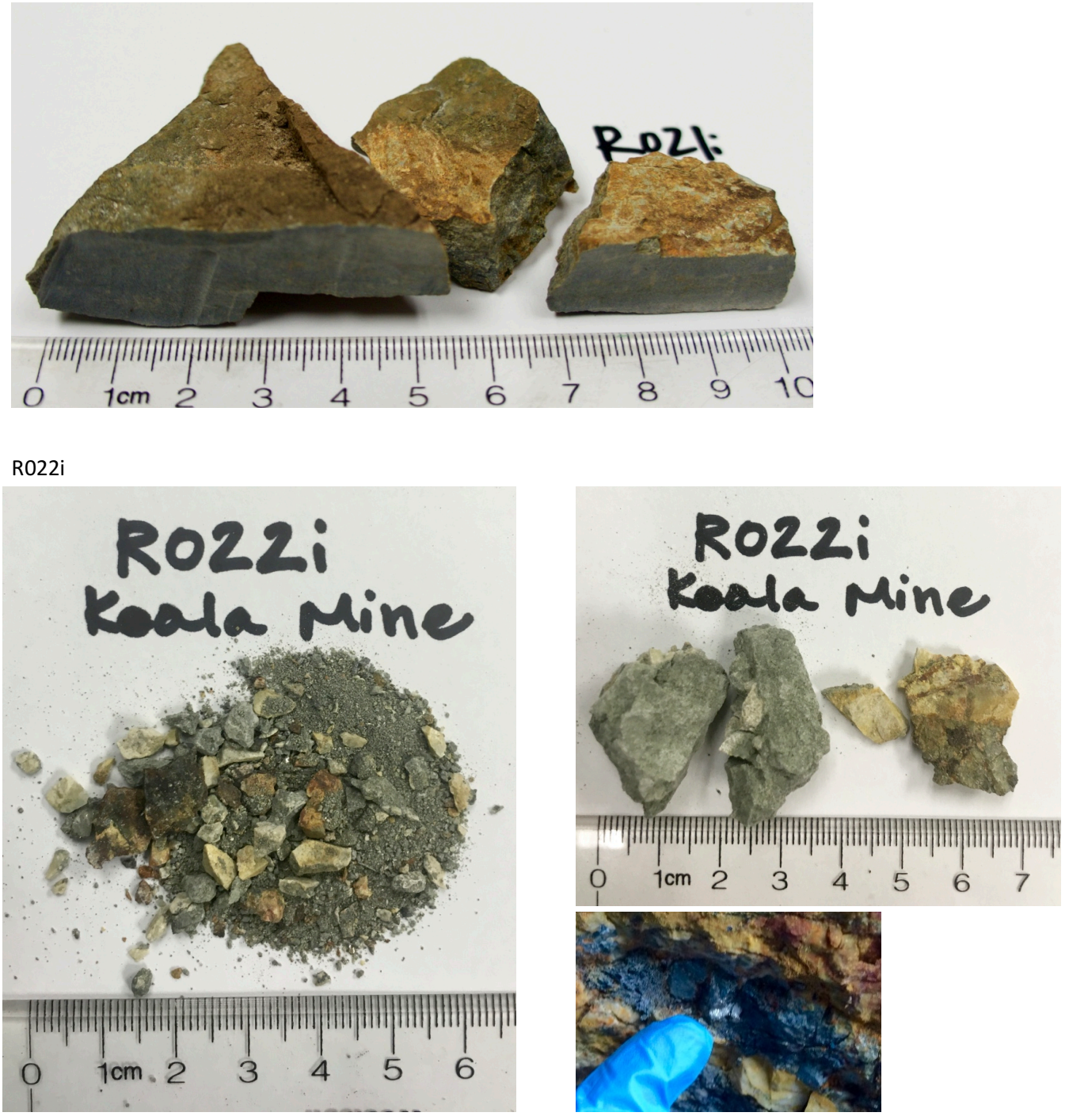

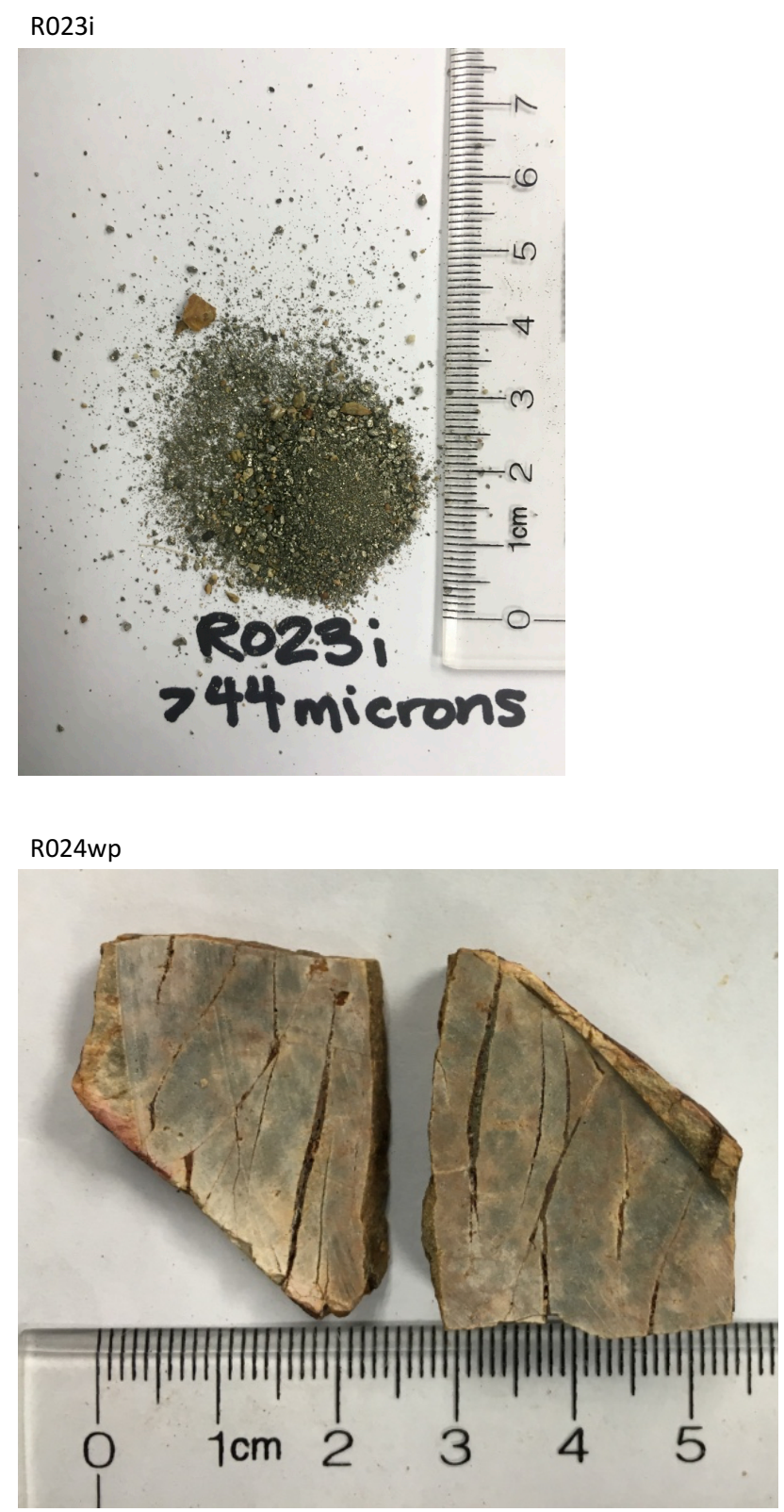

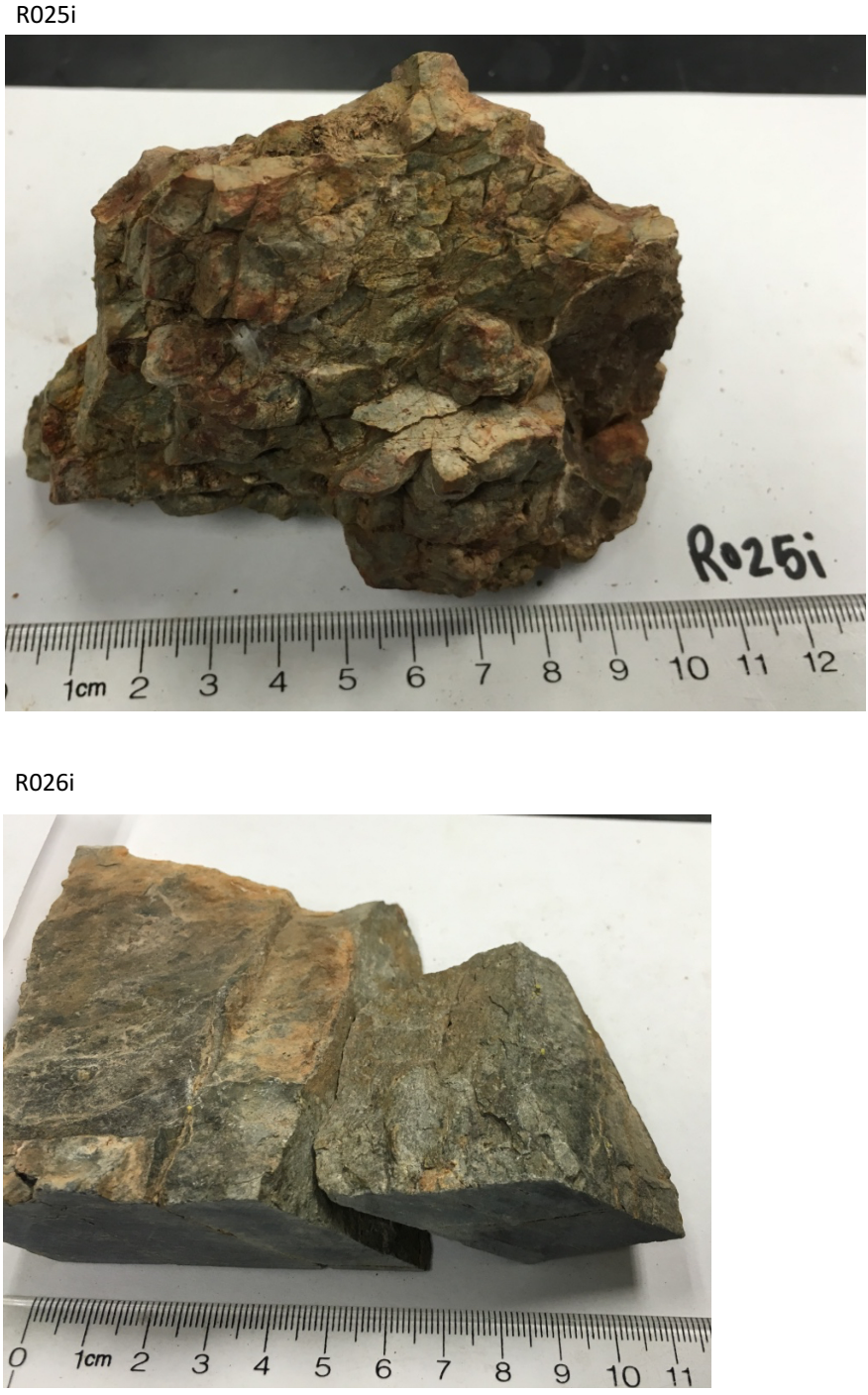

R027wp

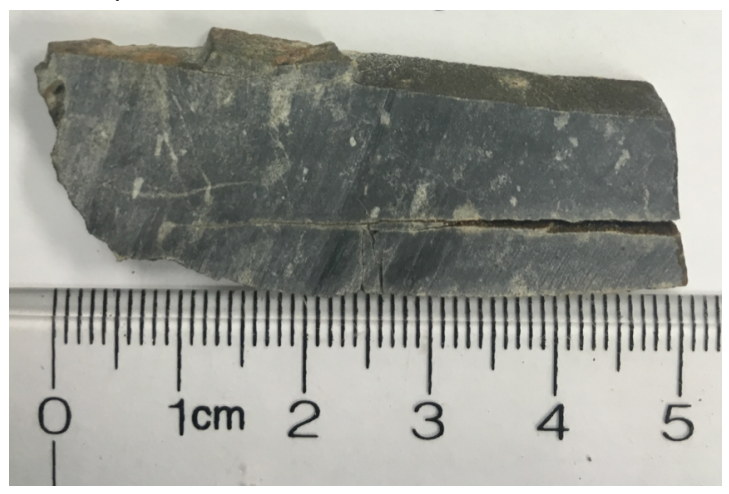



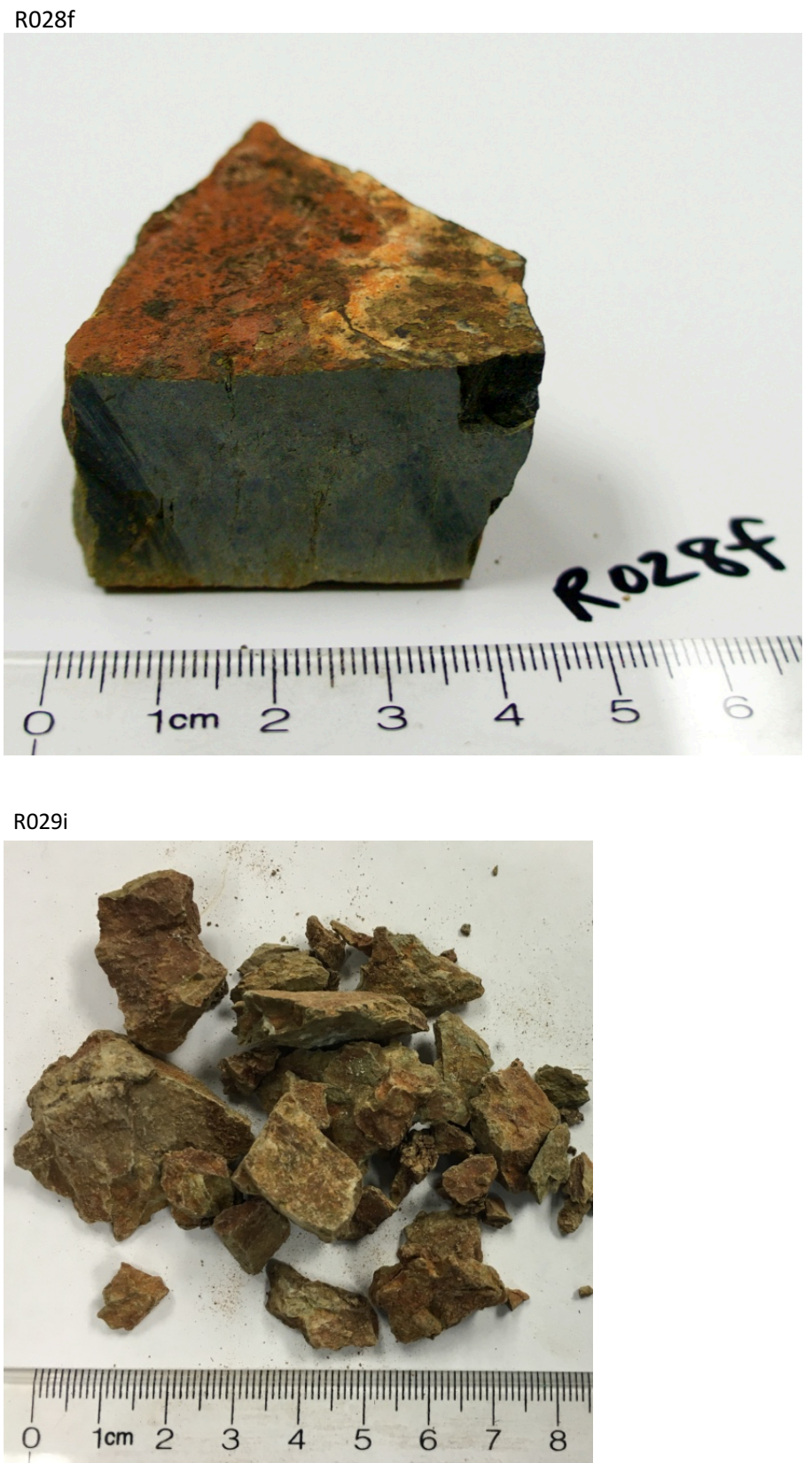

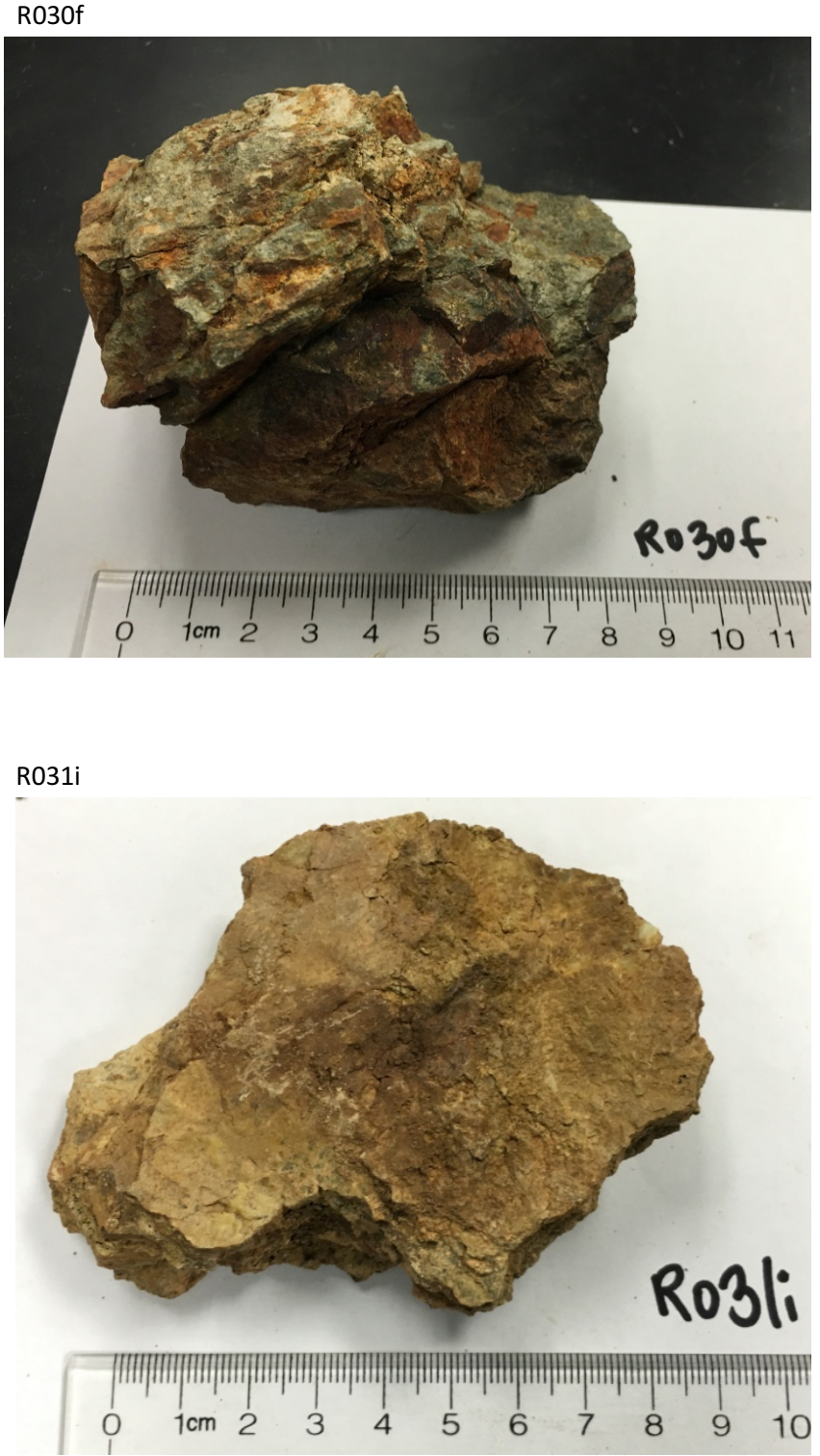

R032wp

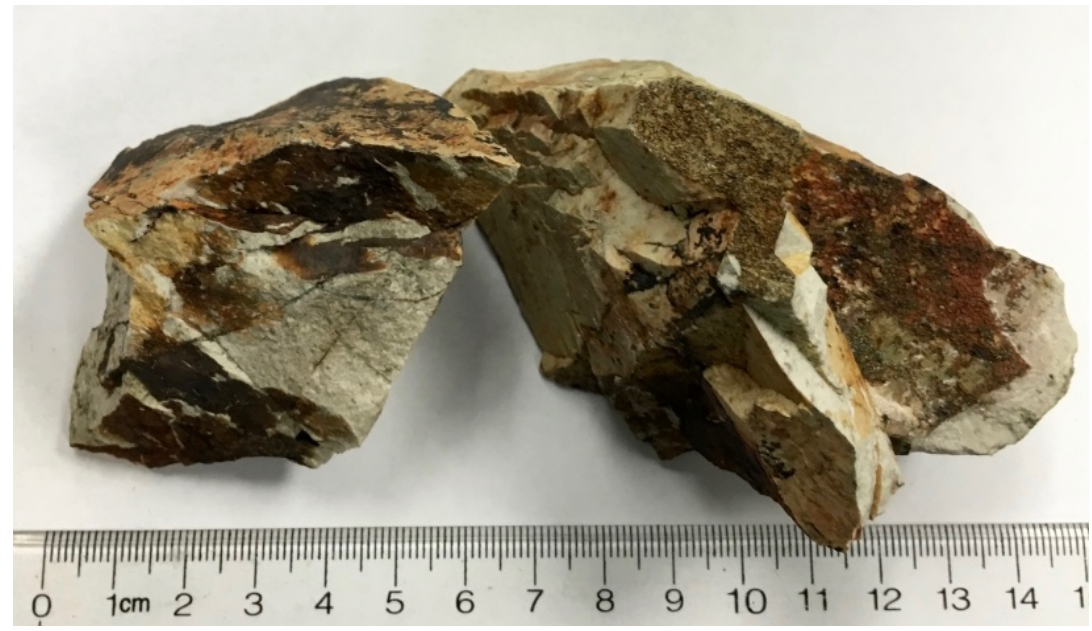


R033f
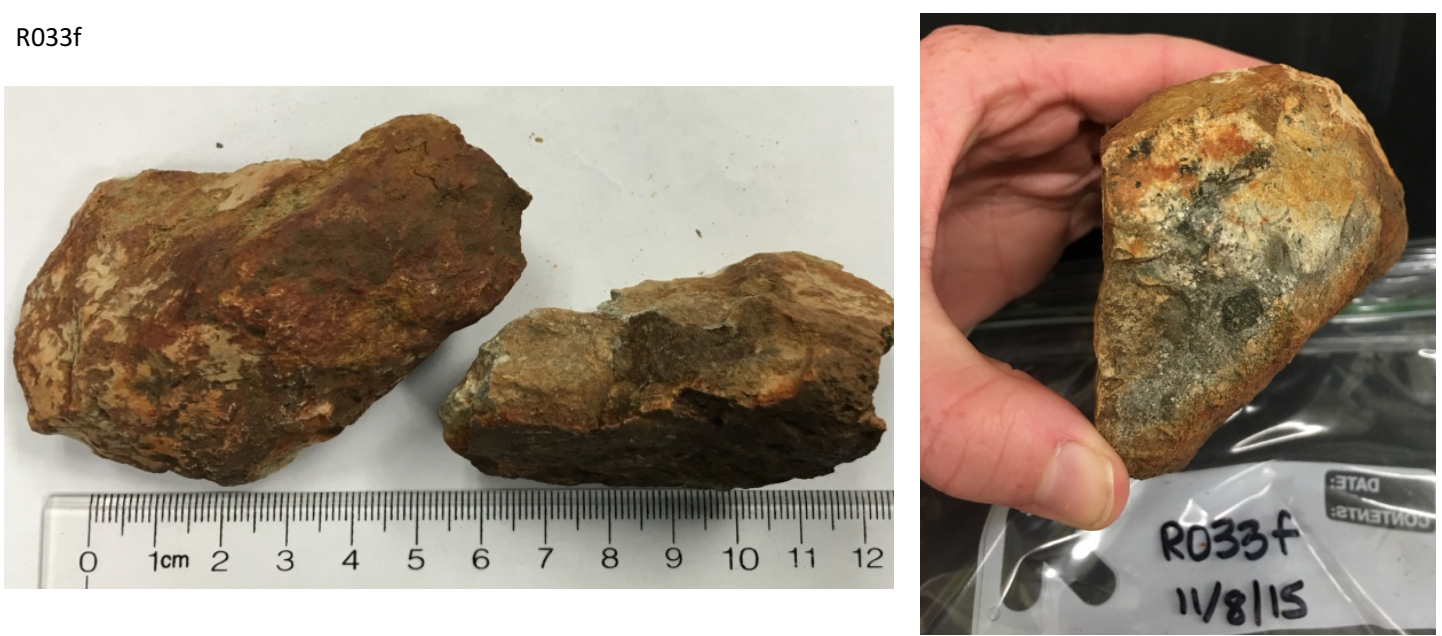

R034f

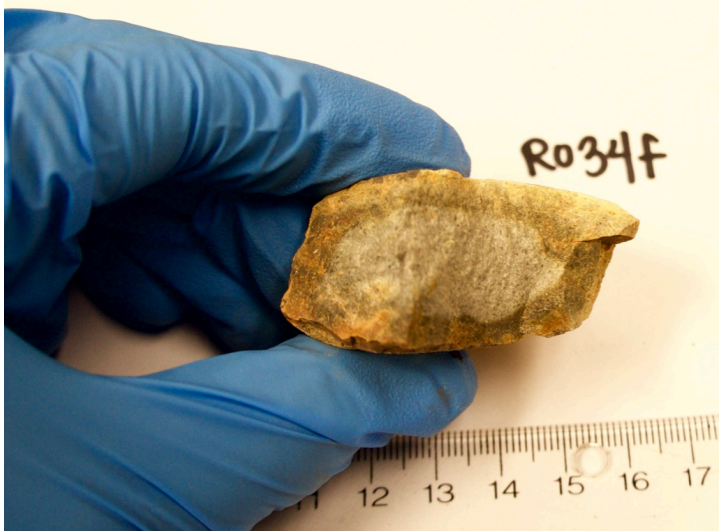

R035wp

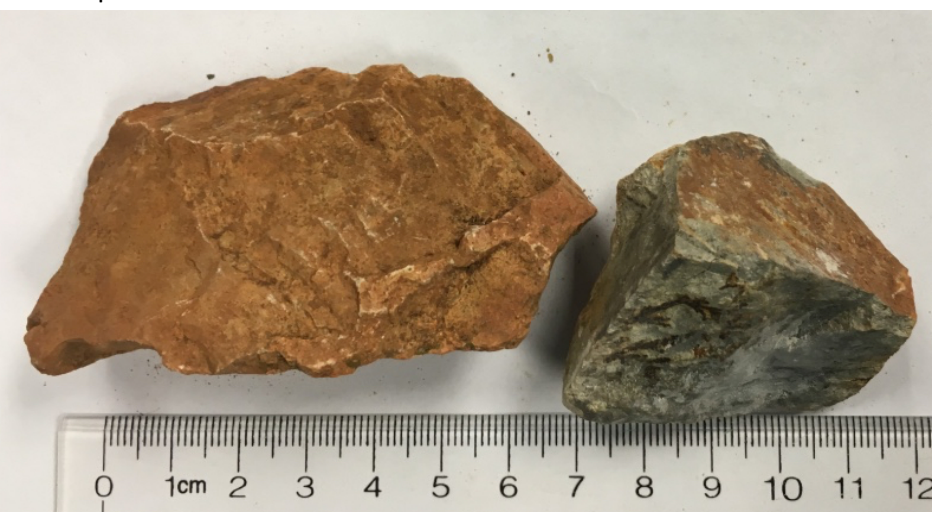




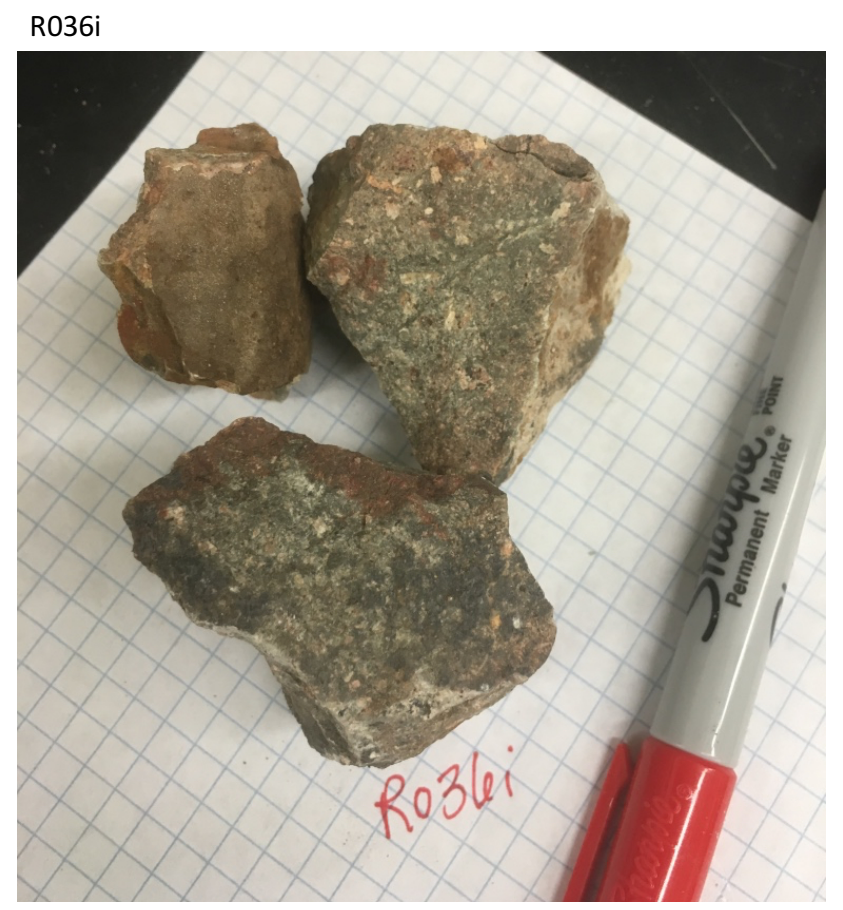

R037i
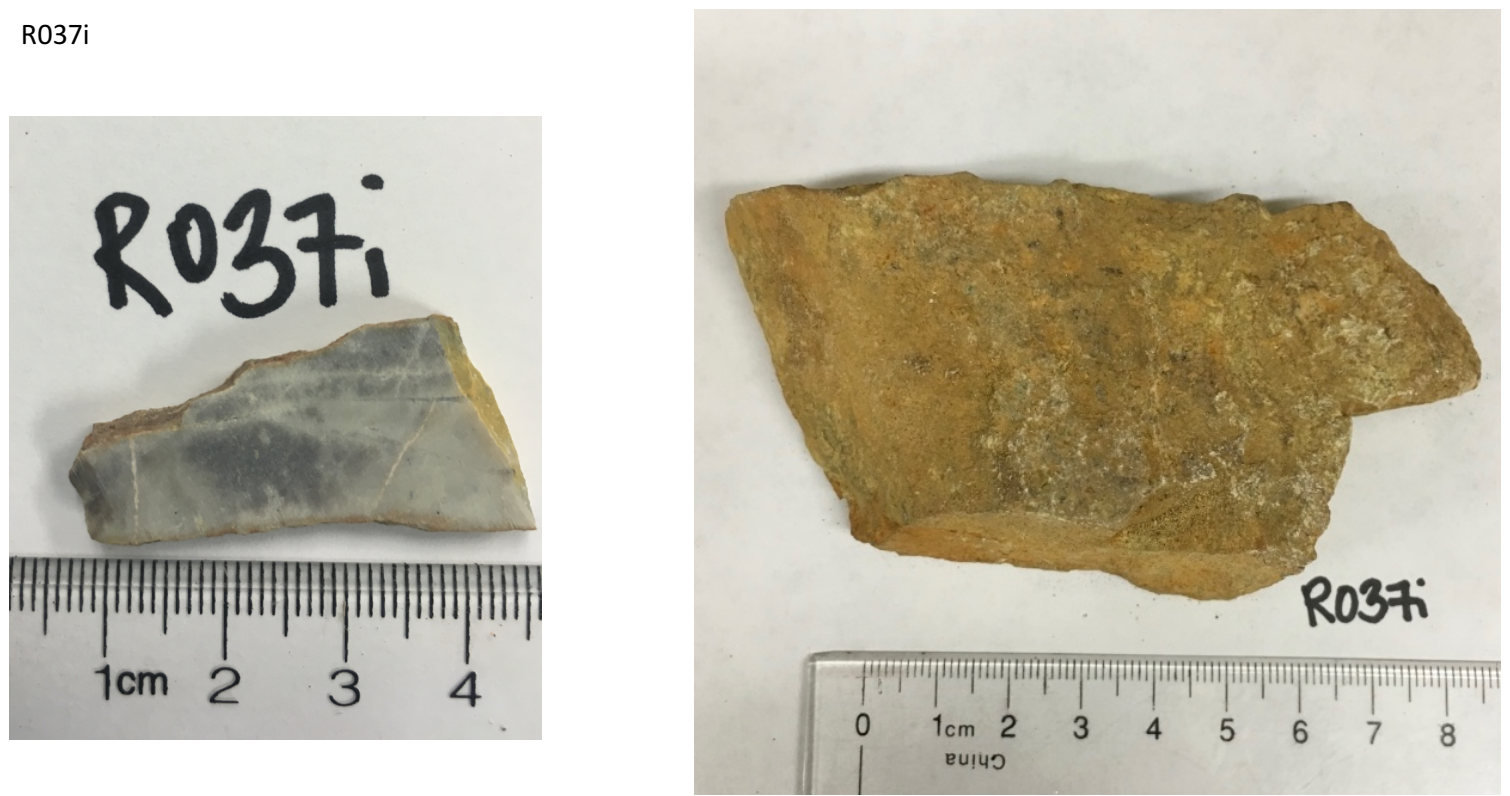

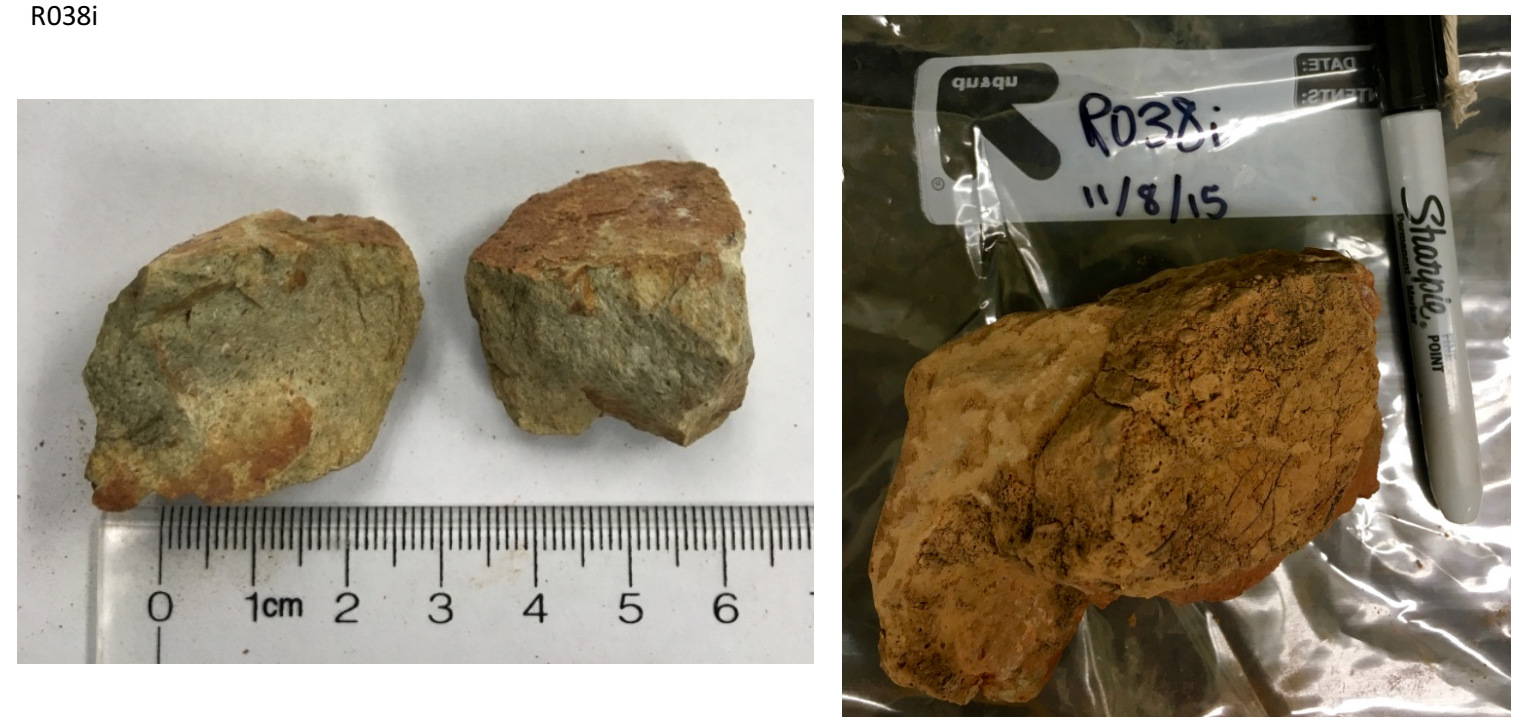

R039i

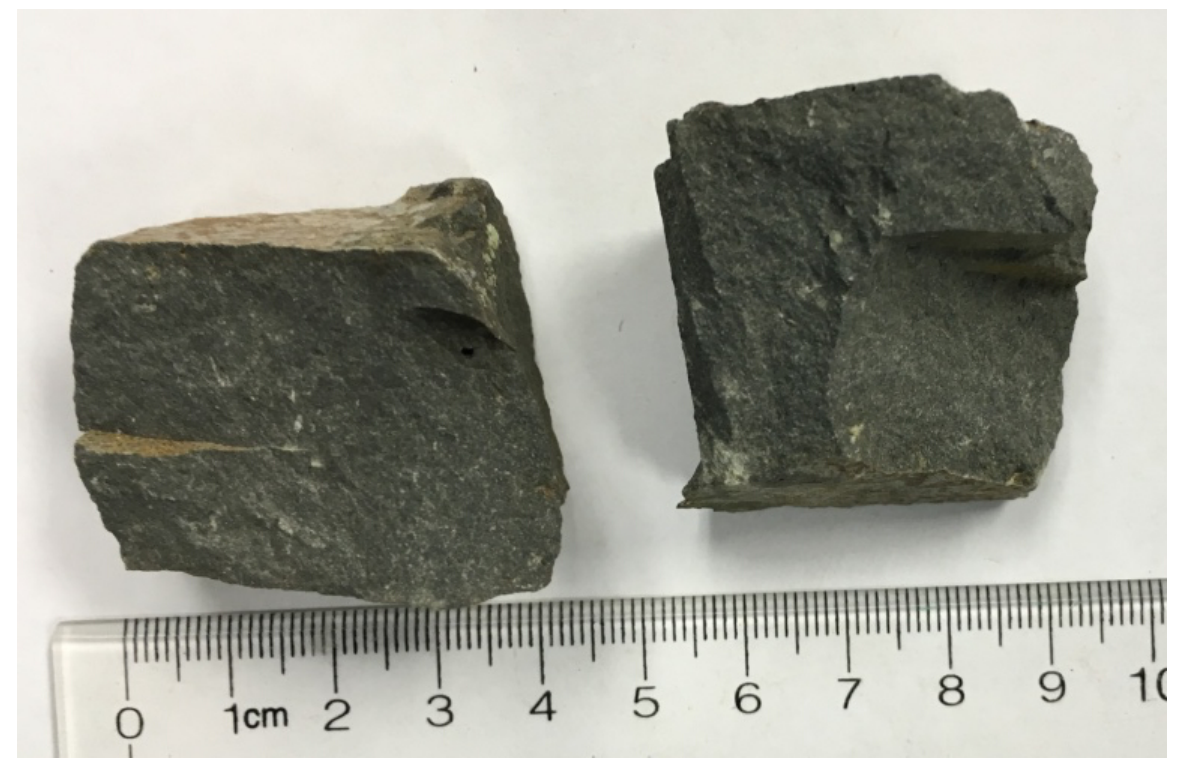




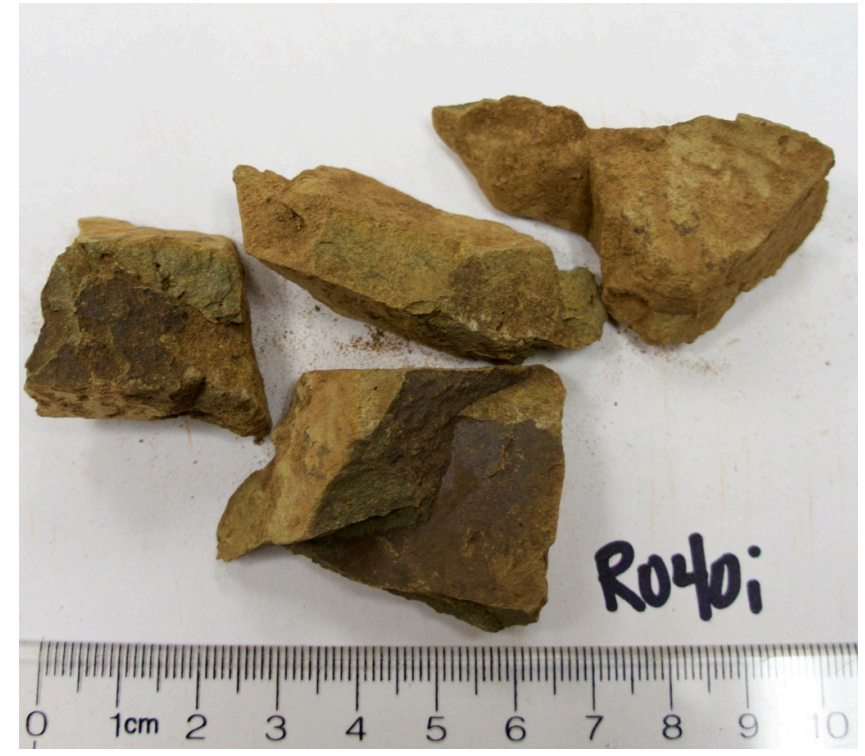

R041i

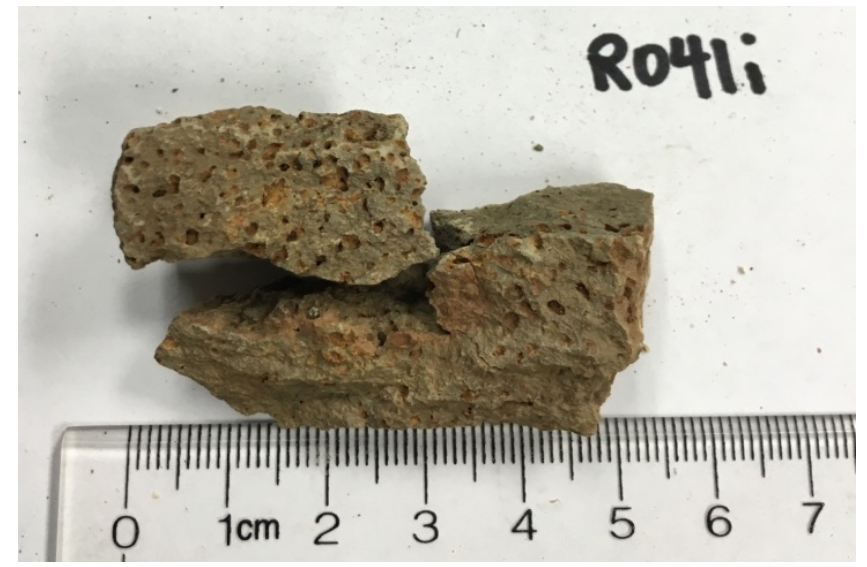

R042i

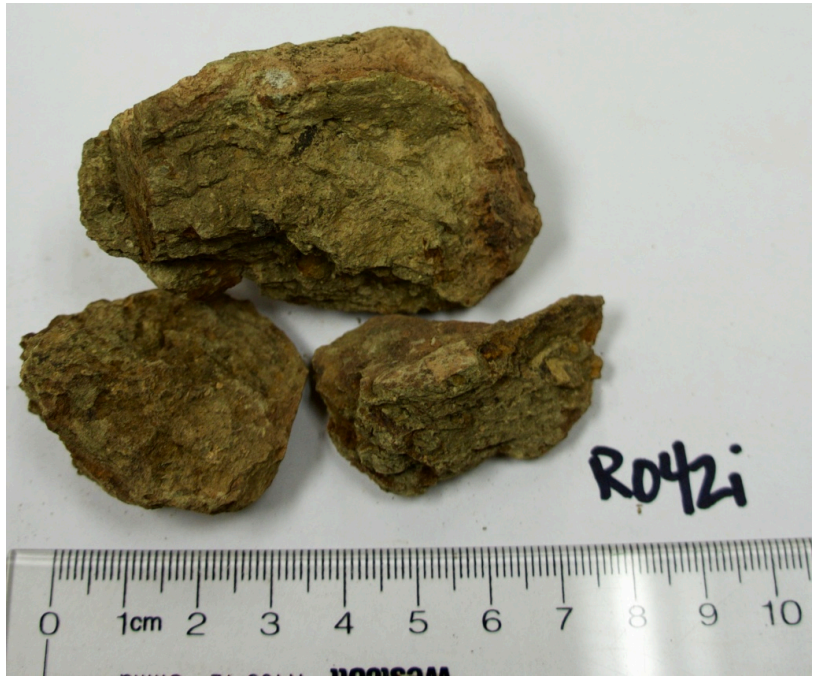




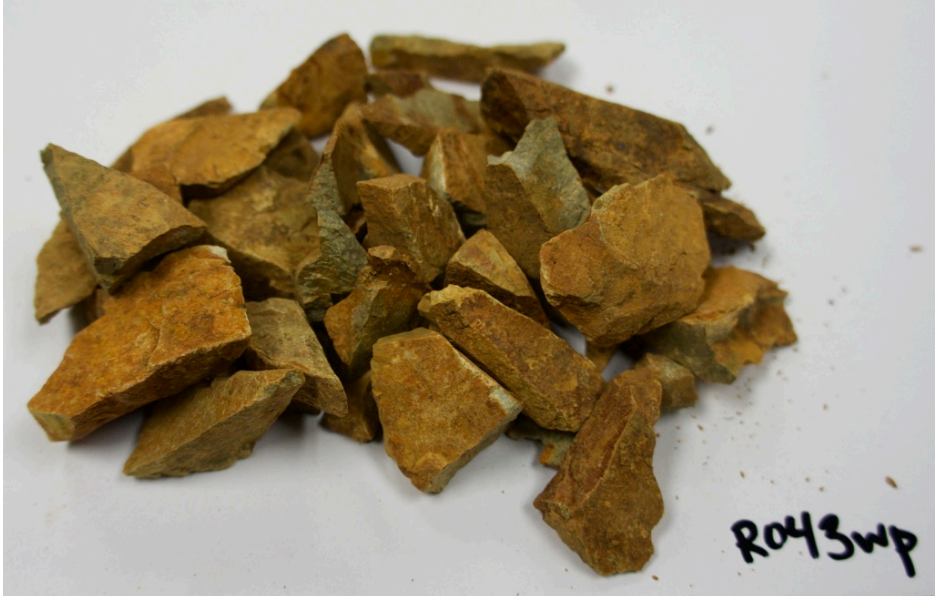

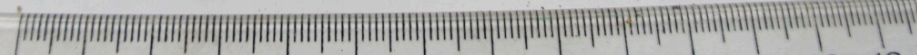

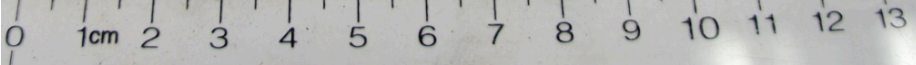

R044i

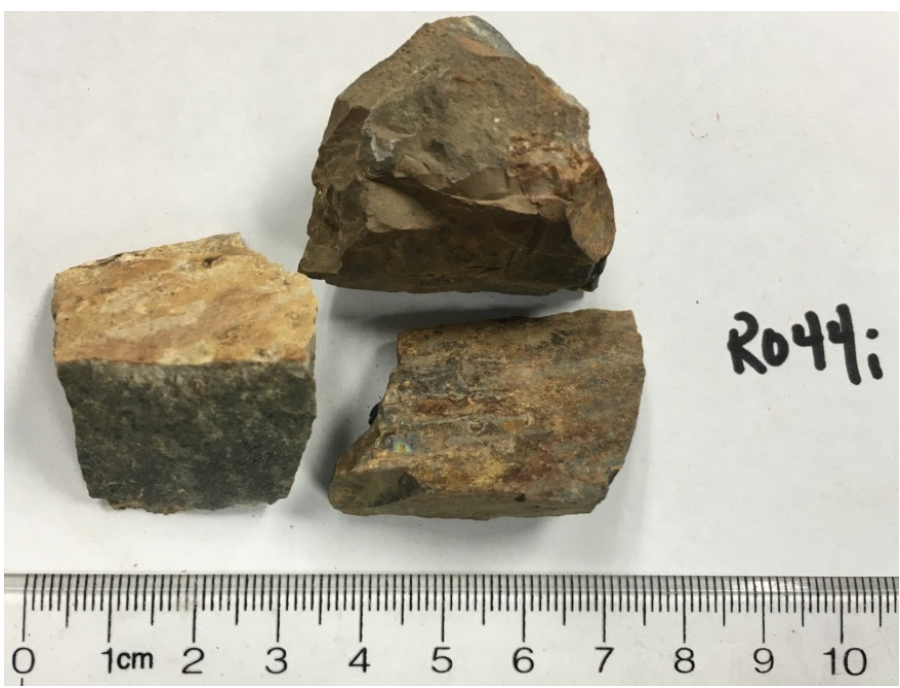

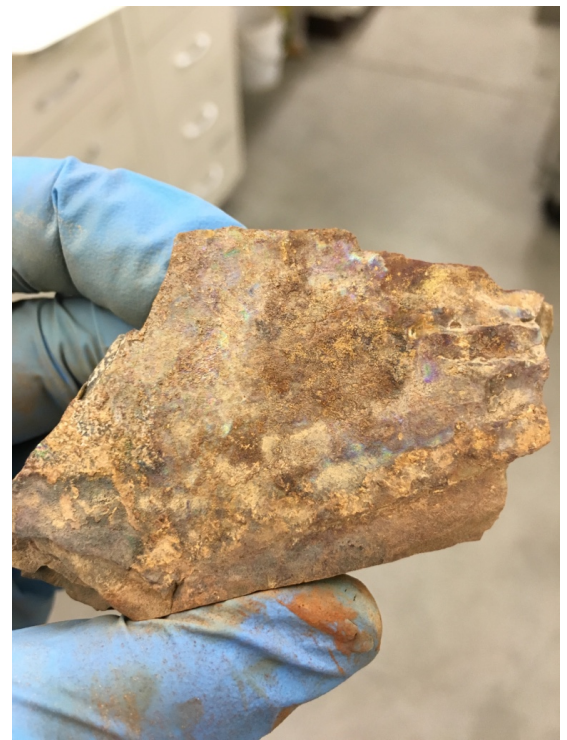




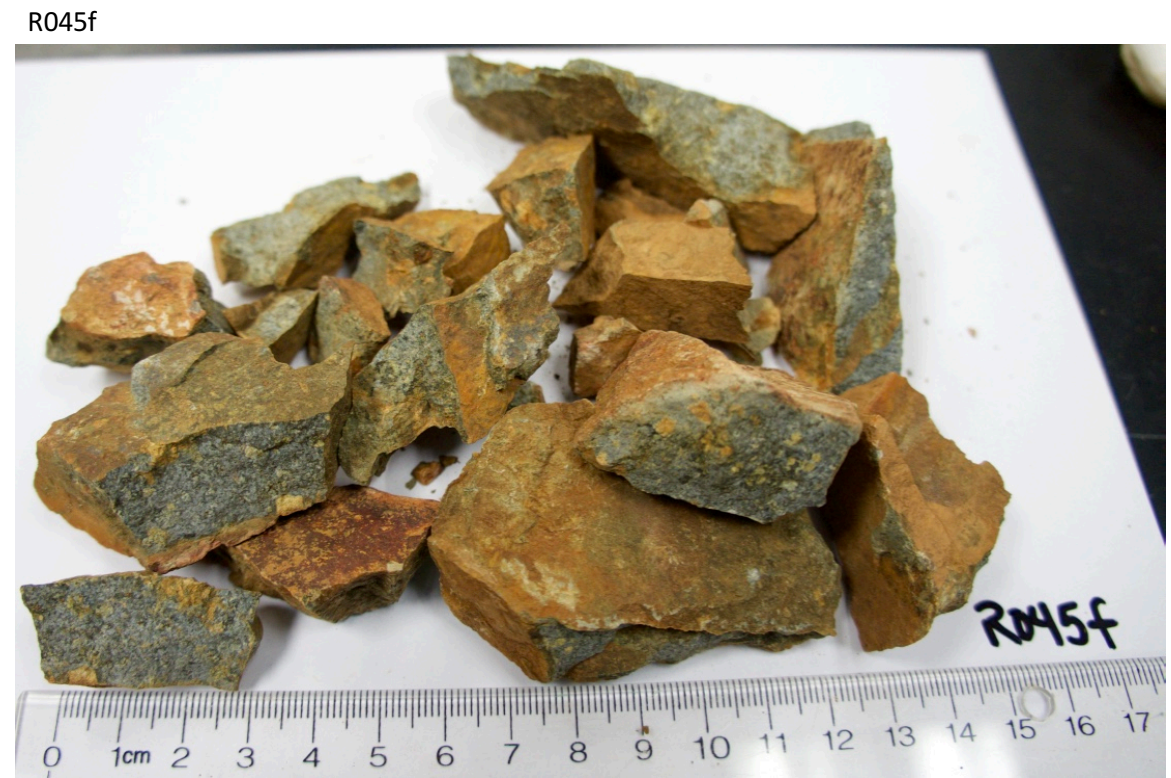

R046i

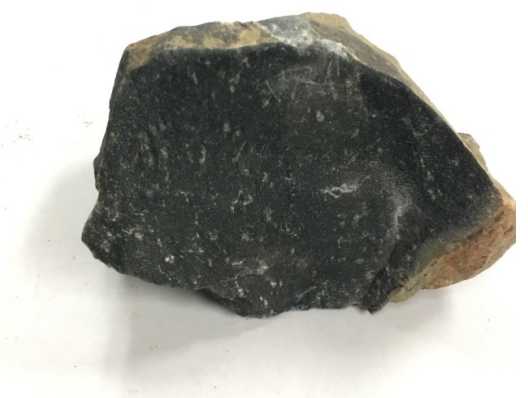

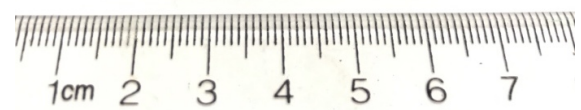

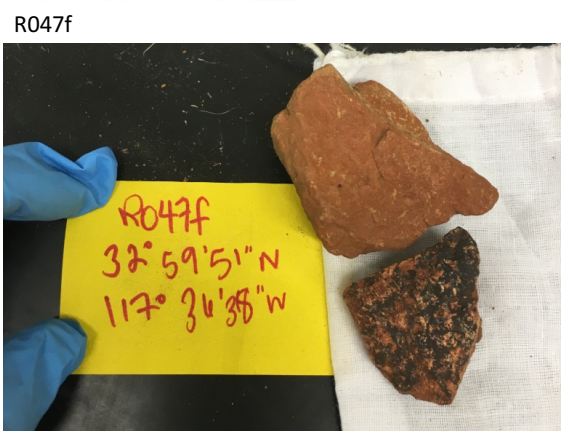


R048i
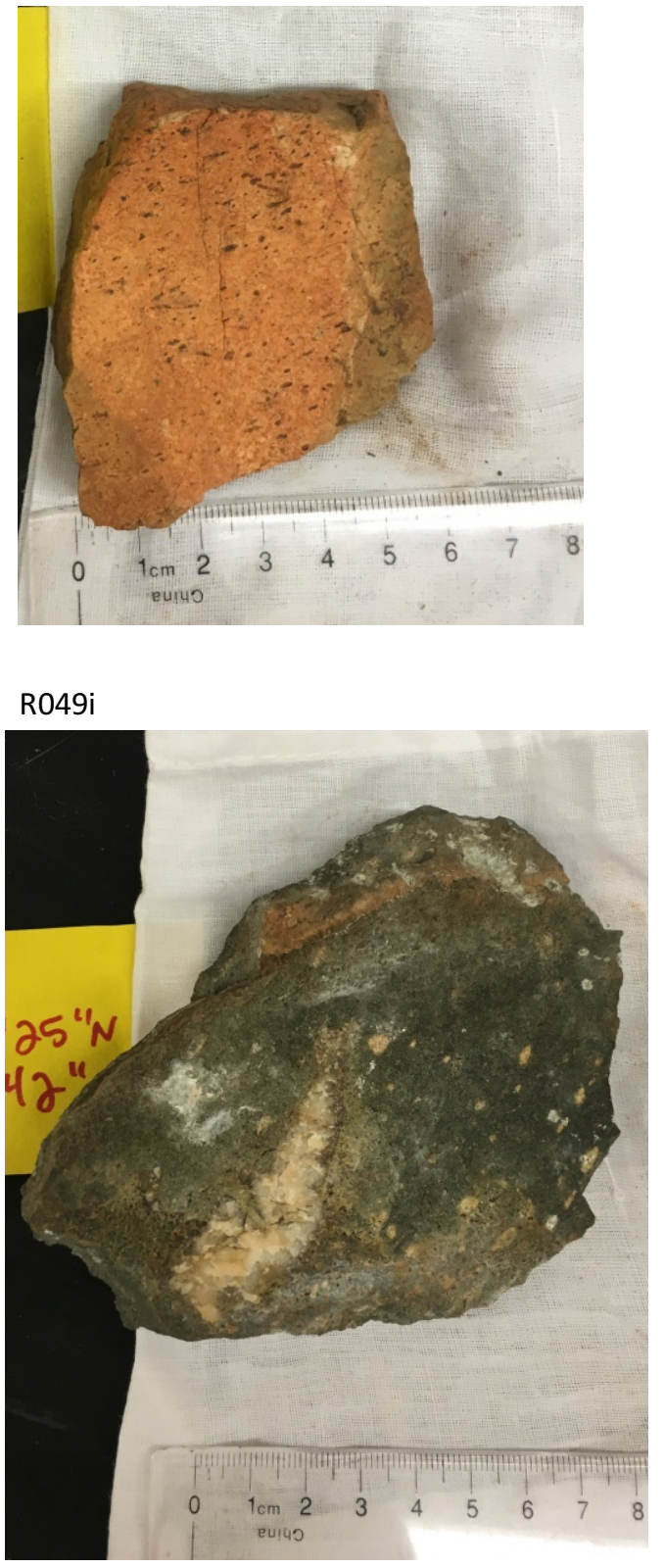


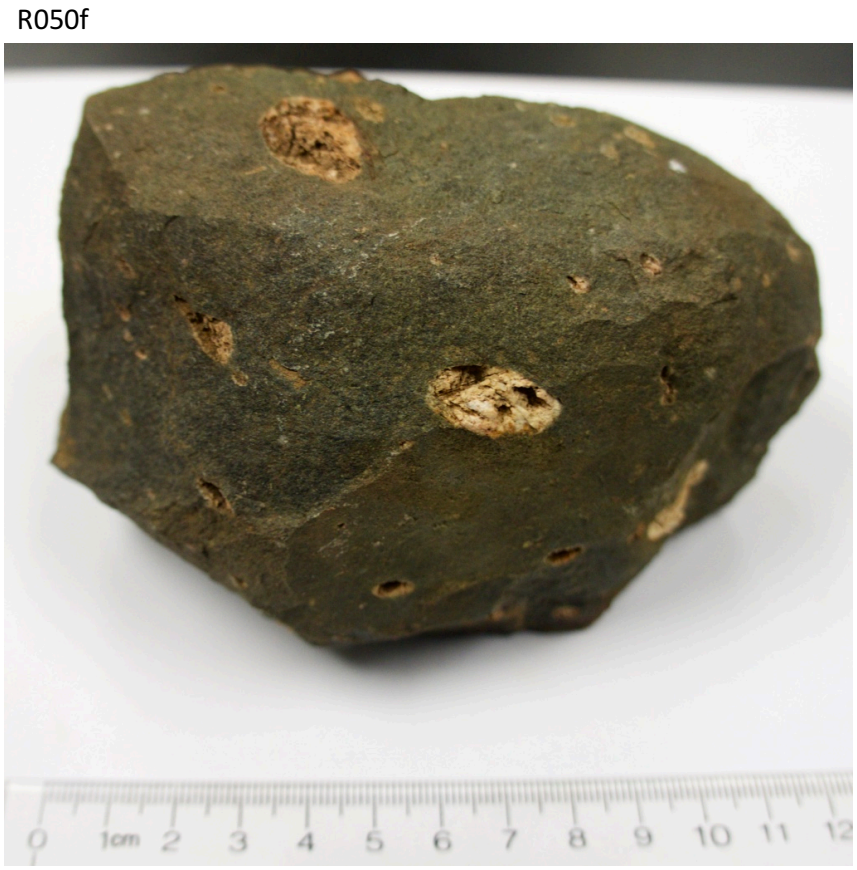

R051i

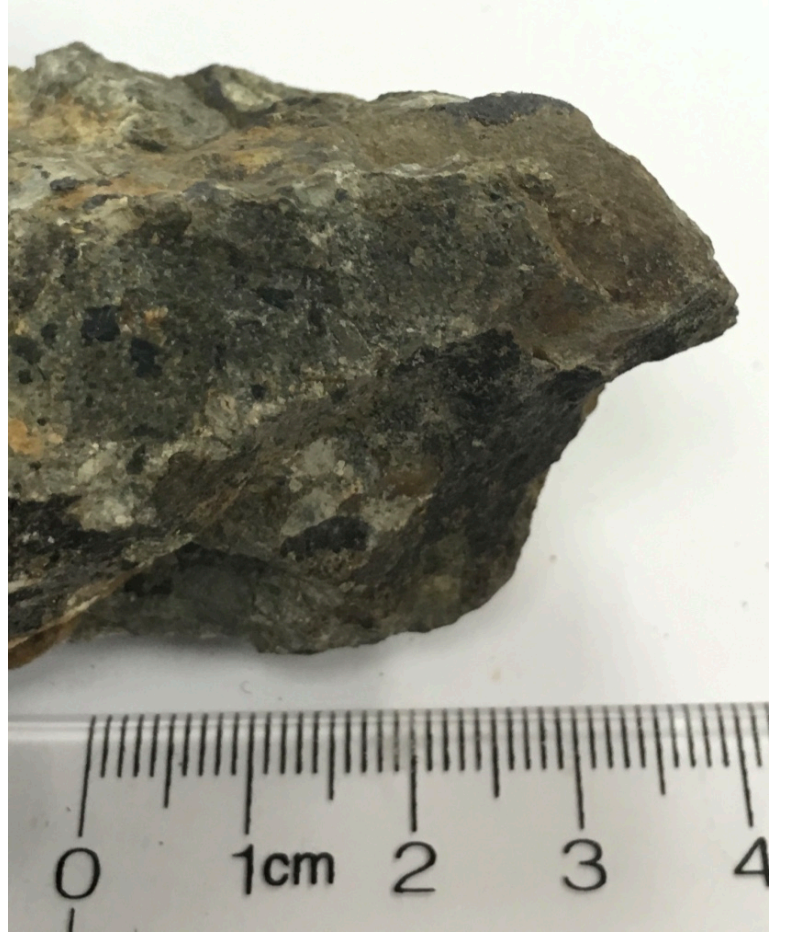




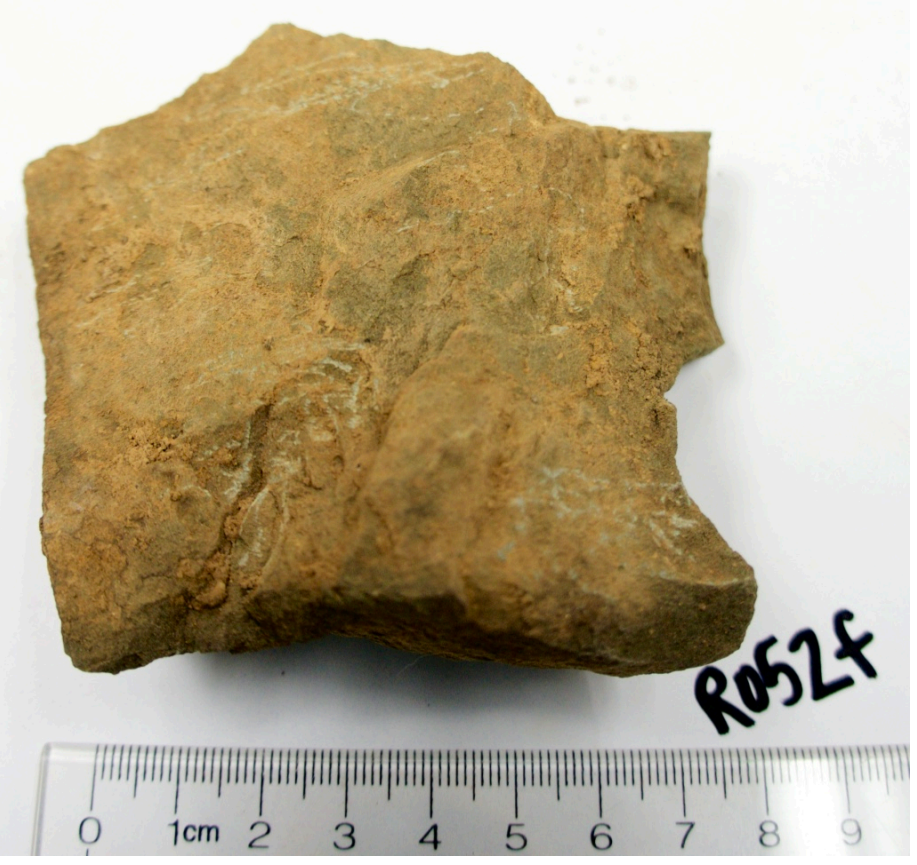

R053i

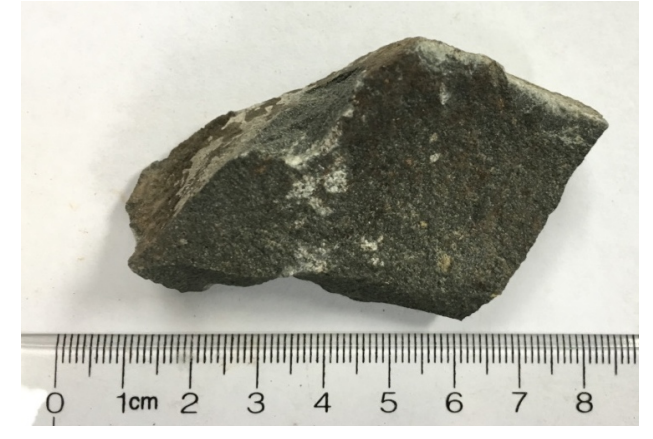

R054i

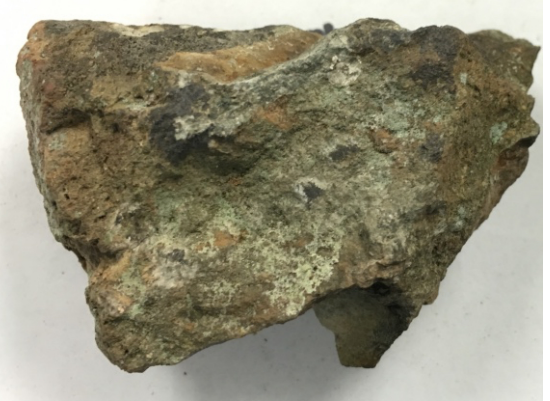

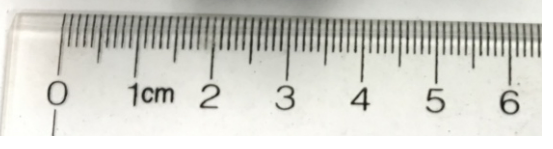



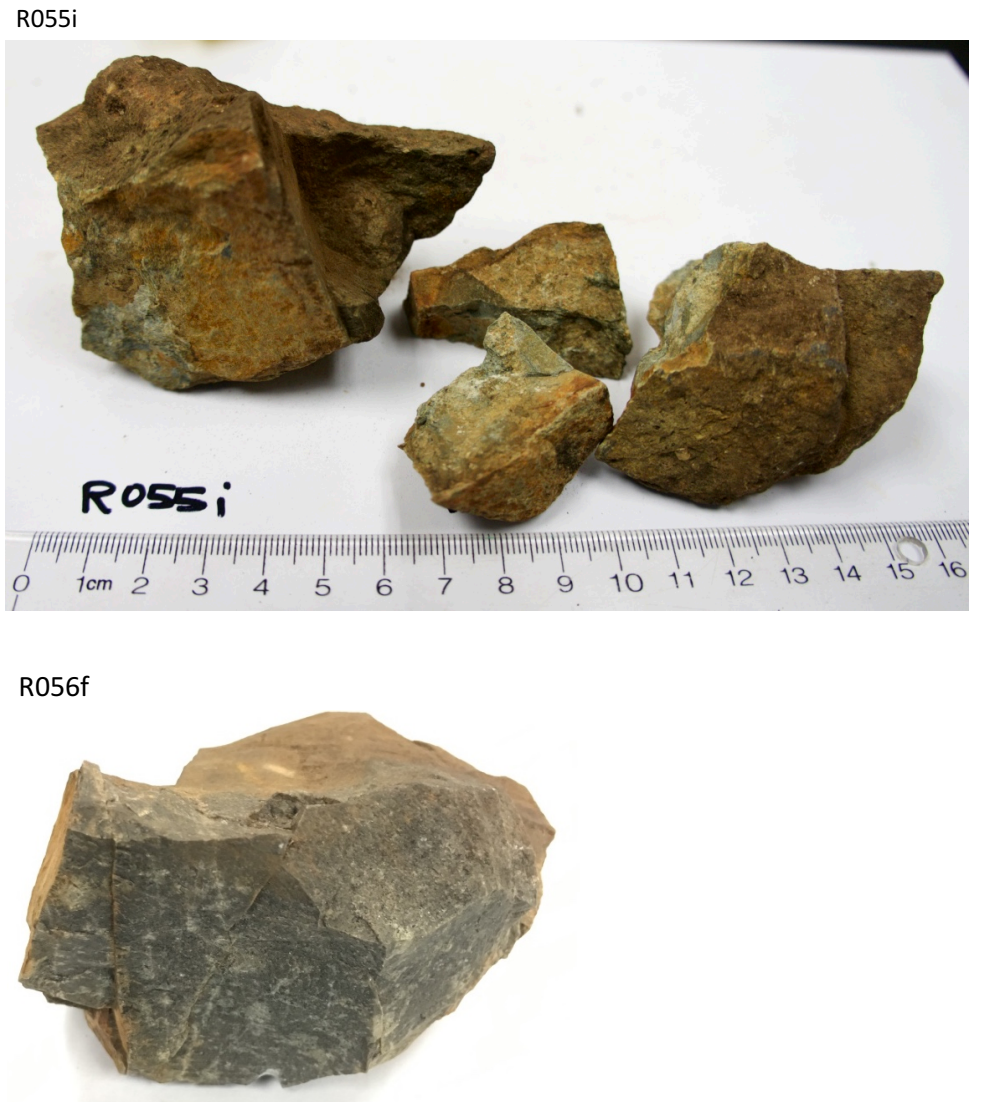

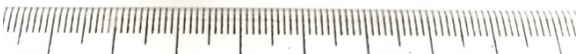

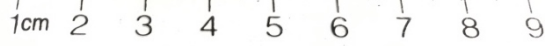

R057i

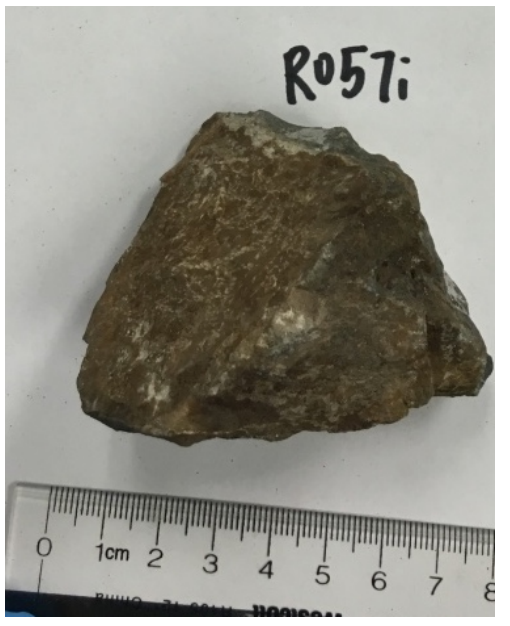



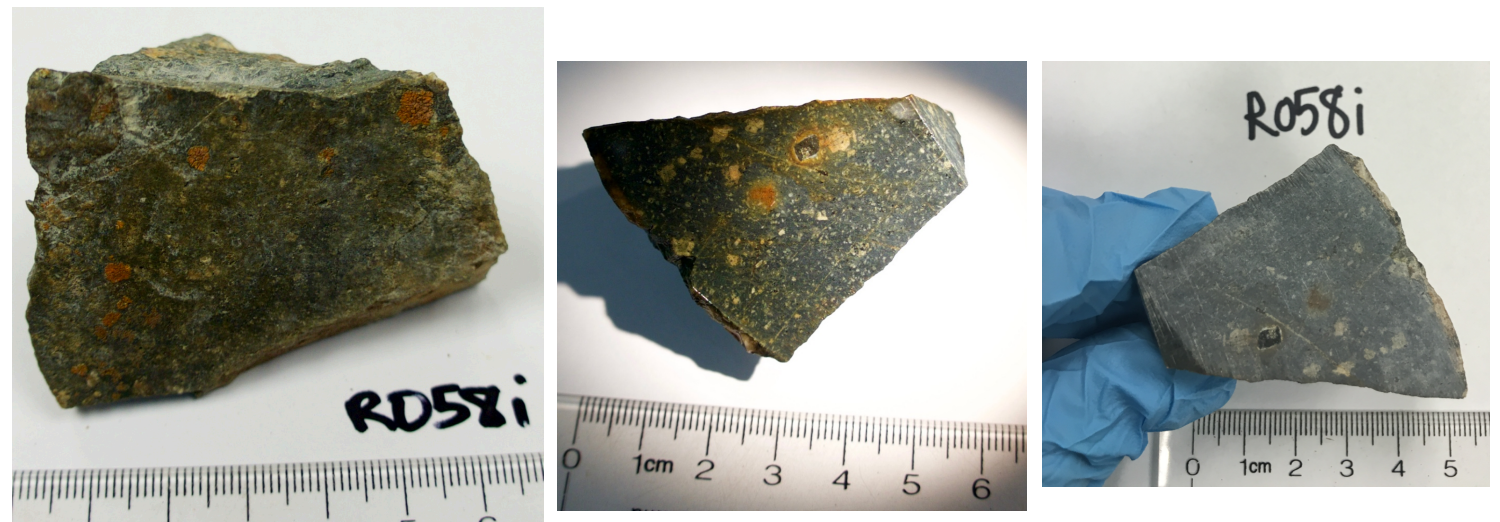

$$
\text { ) } 1 \mathrm{~cm} 23456
$$

R059i

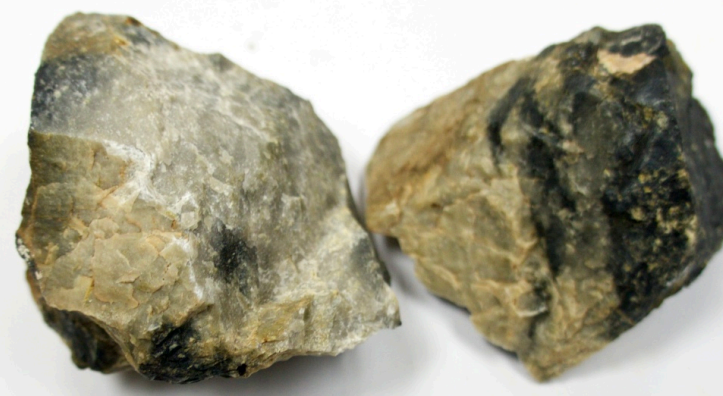

\section{RO59i}

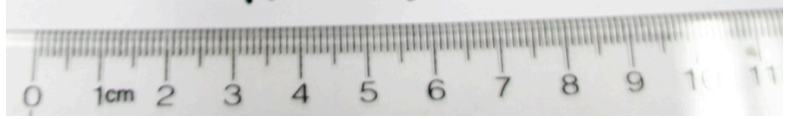

R060i
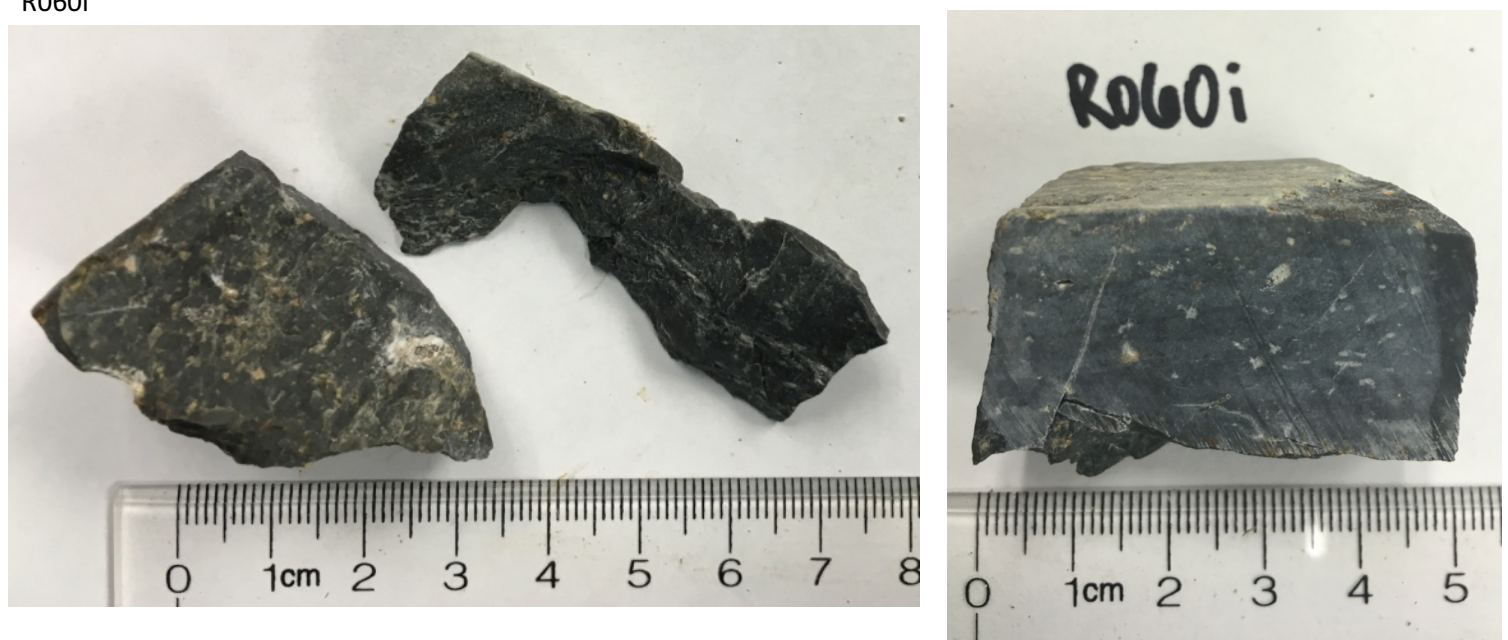
R061i
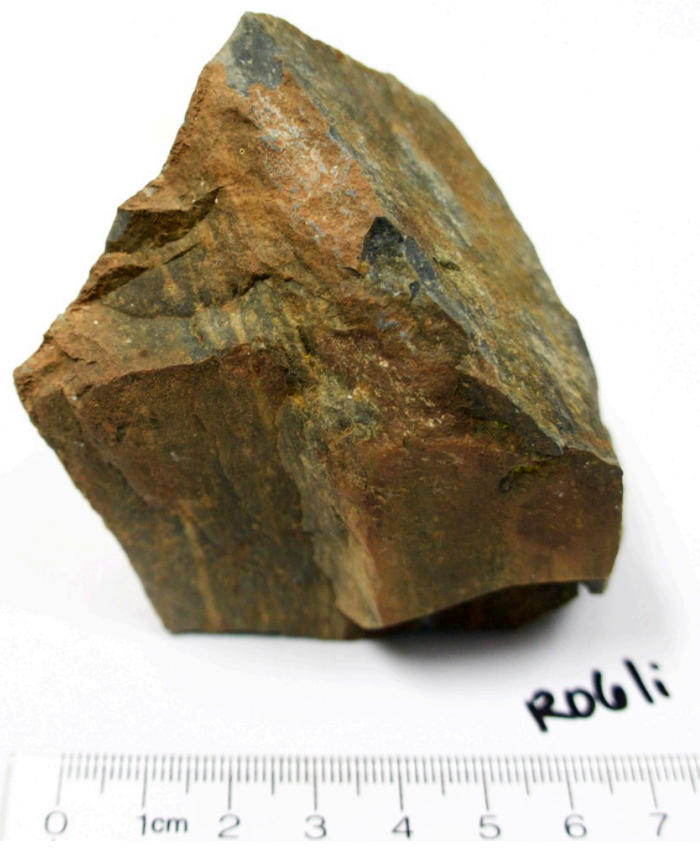

\section{R062i}

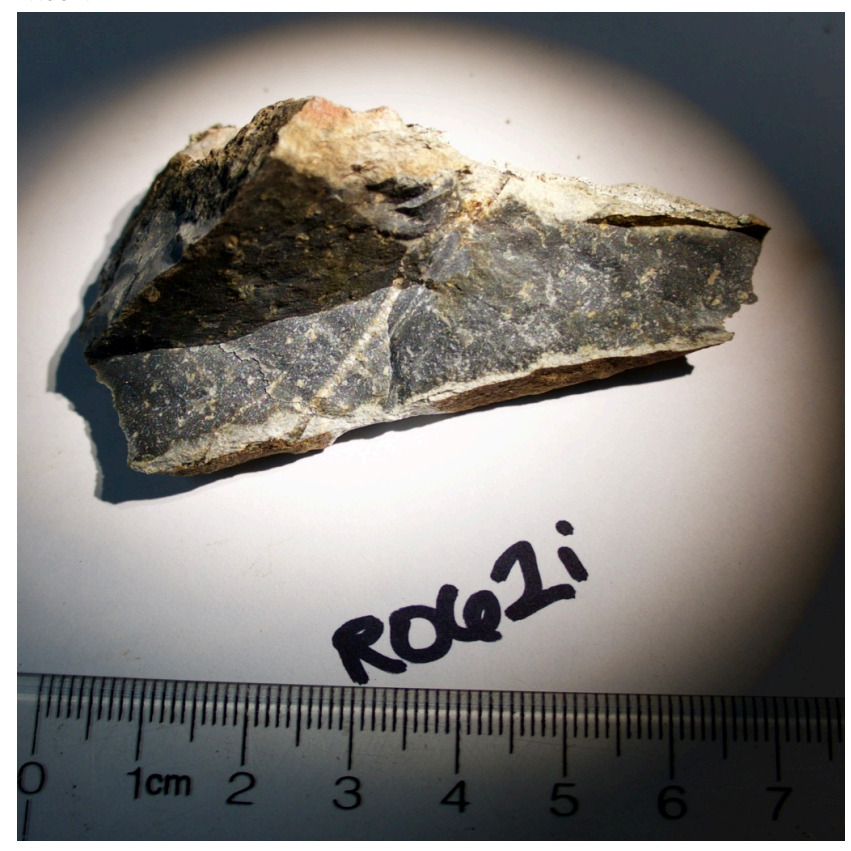




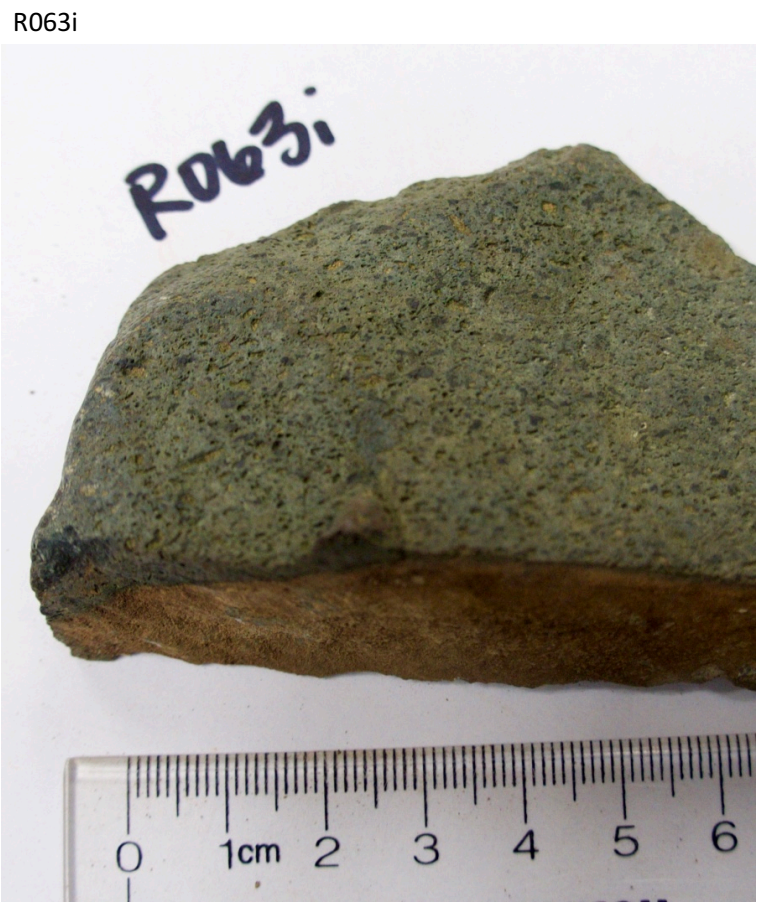

R064i

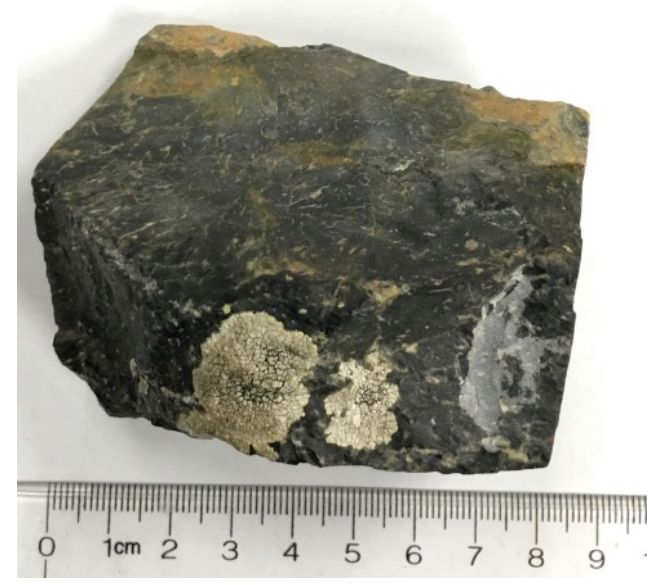


R065i

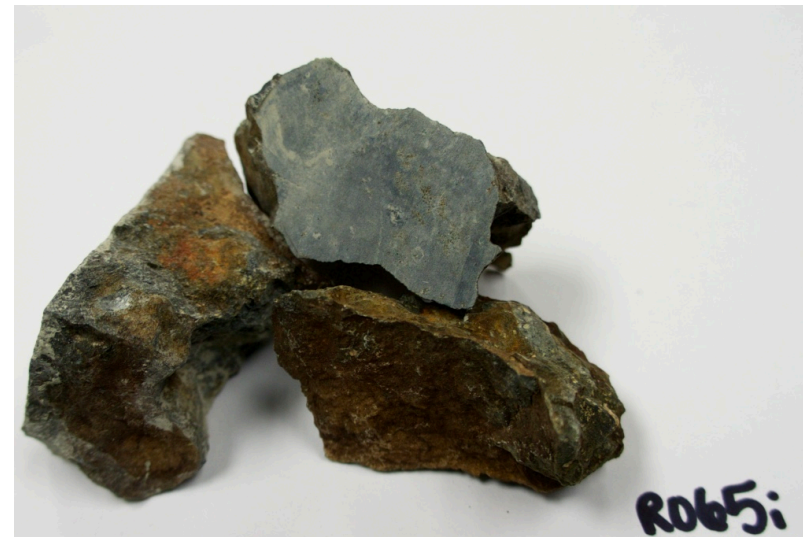

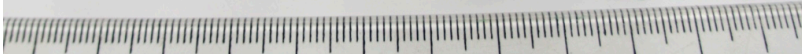
$\begin{array}{llllllllllll}1 \mathrm{~cm} & 2 & 3 & 4 & 5 & 6 & 7 & 8 & 9 & 10 & 11 & 12\end{array}$

R066i

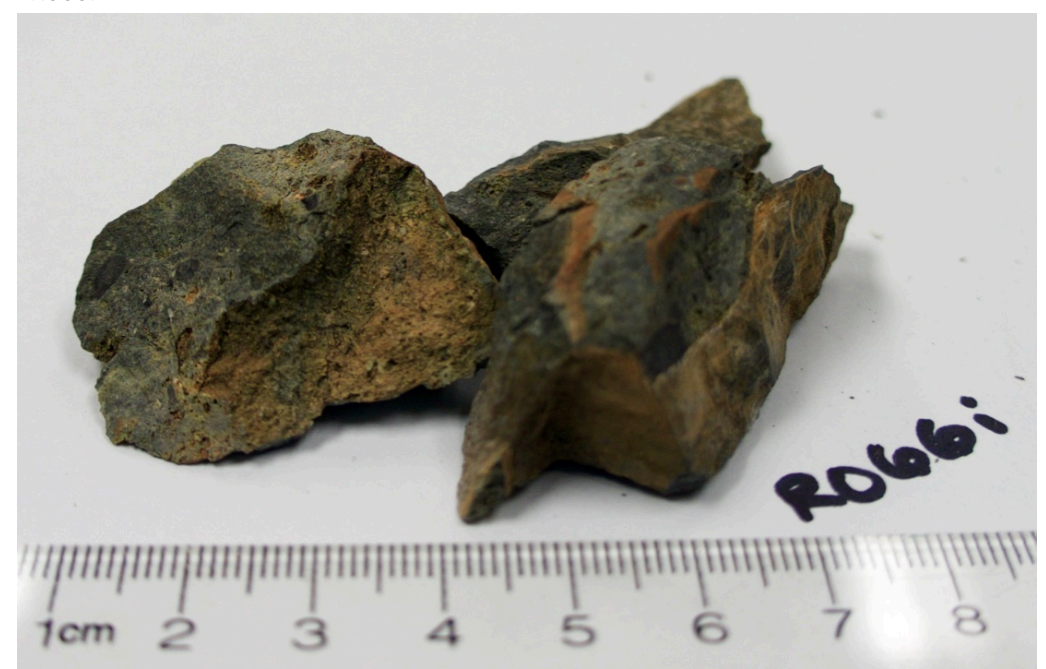

Rolbi

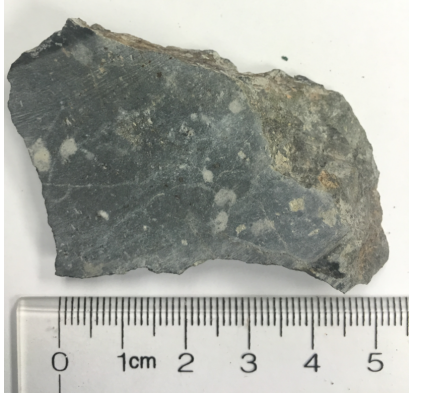

$\begin{array}{lllll}1 \mathrm{~cm} & 2 & 3 & 4 & 5\end{array}$ 

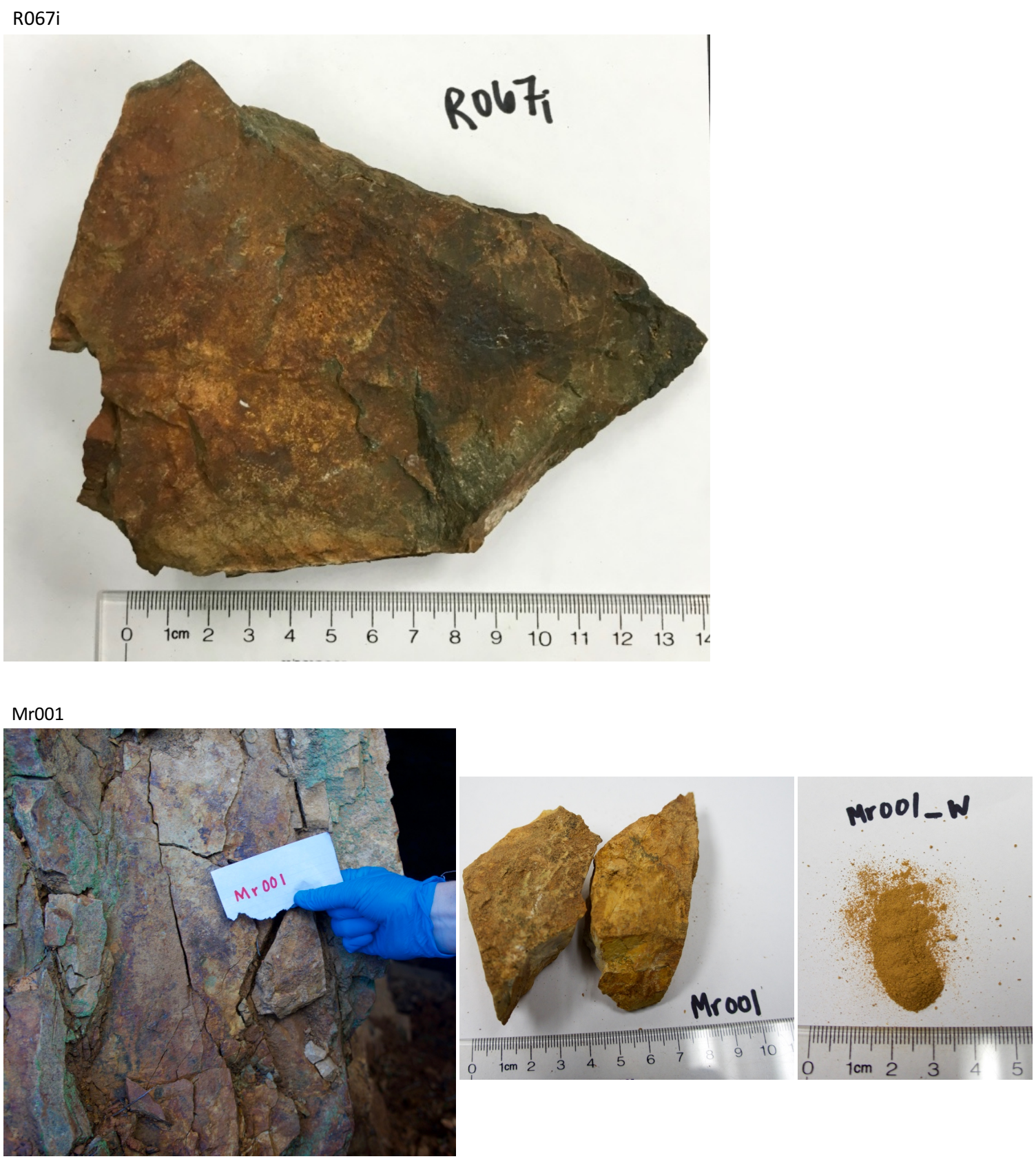

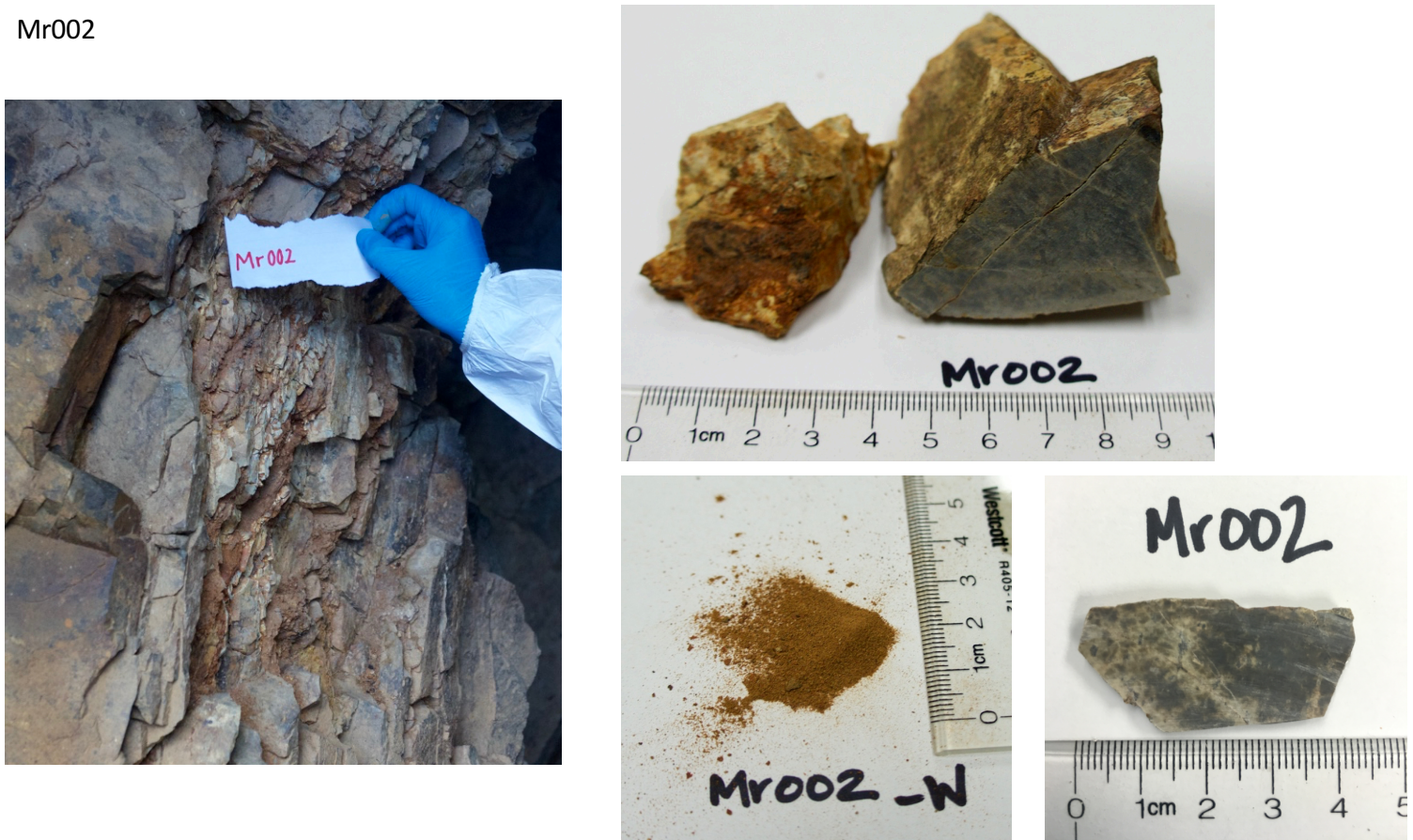

Mr003
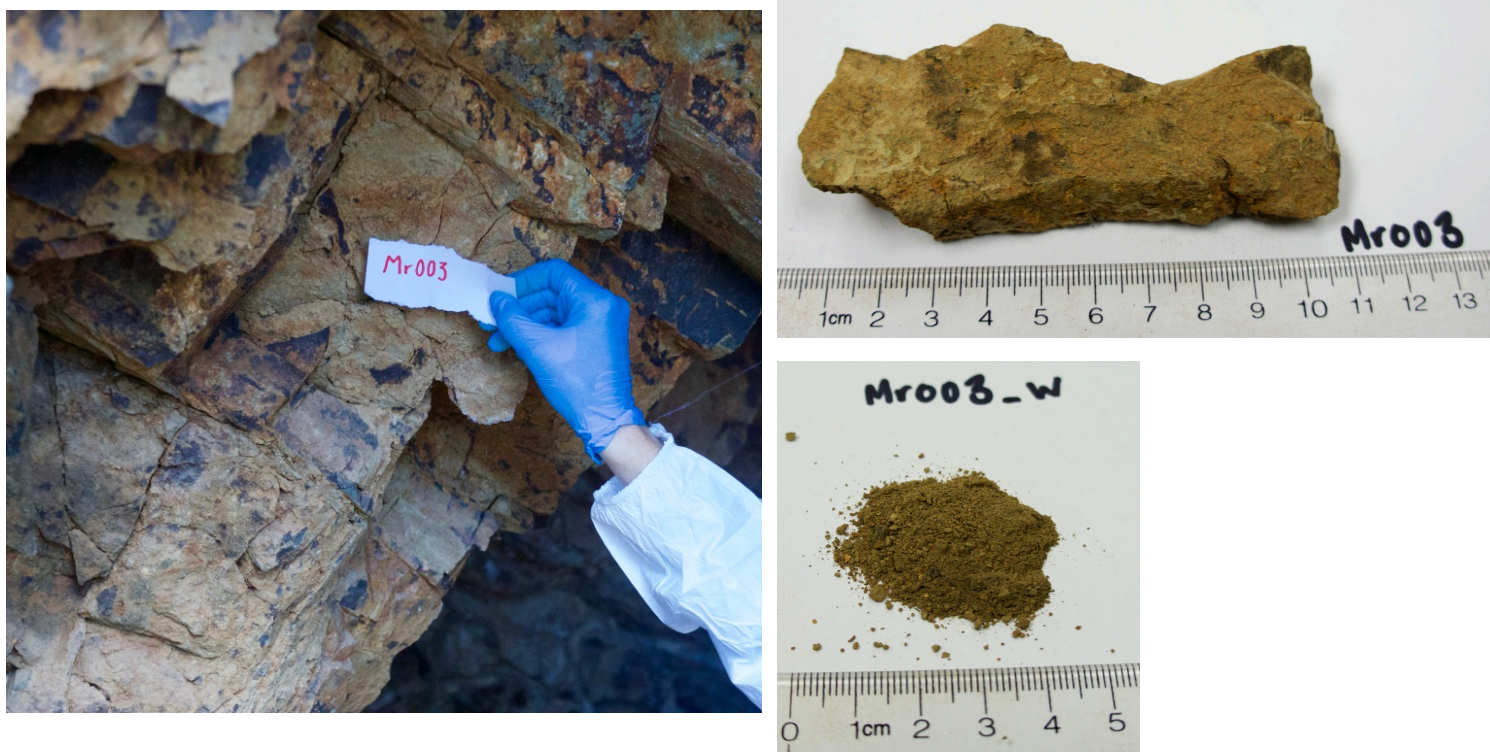

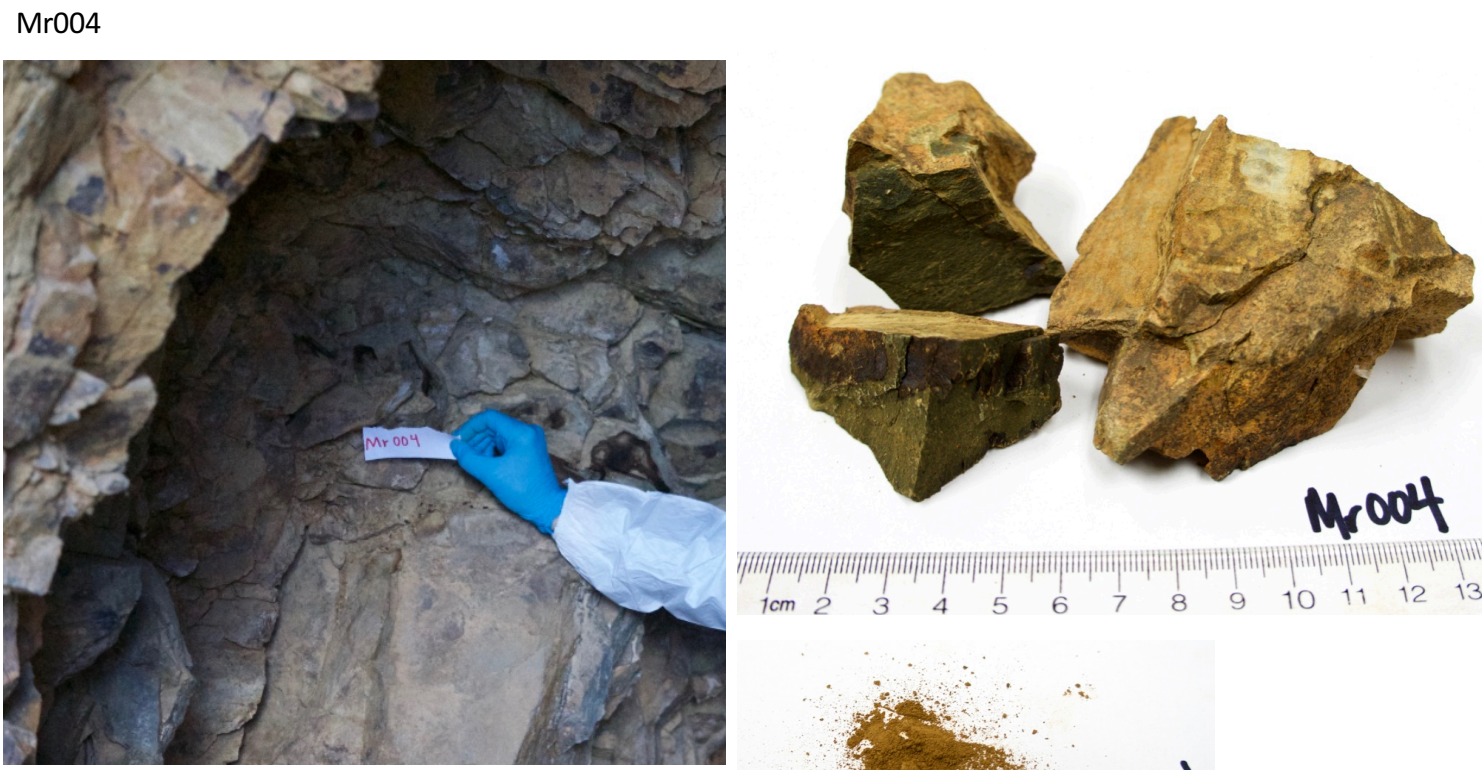

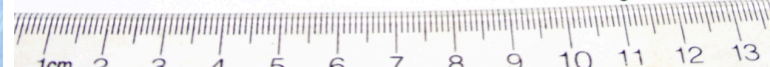

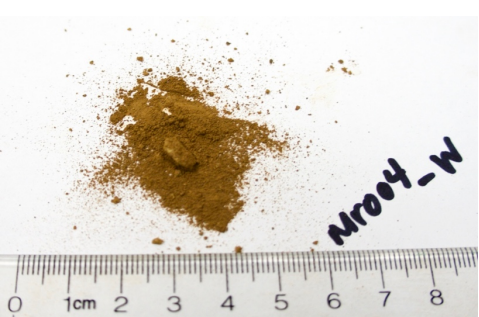

Mr005
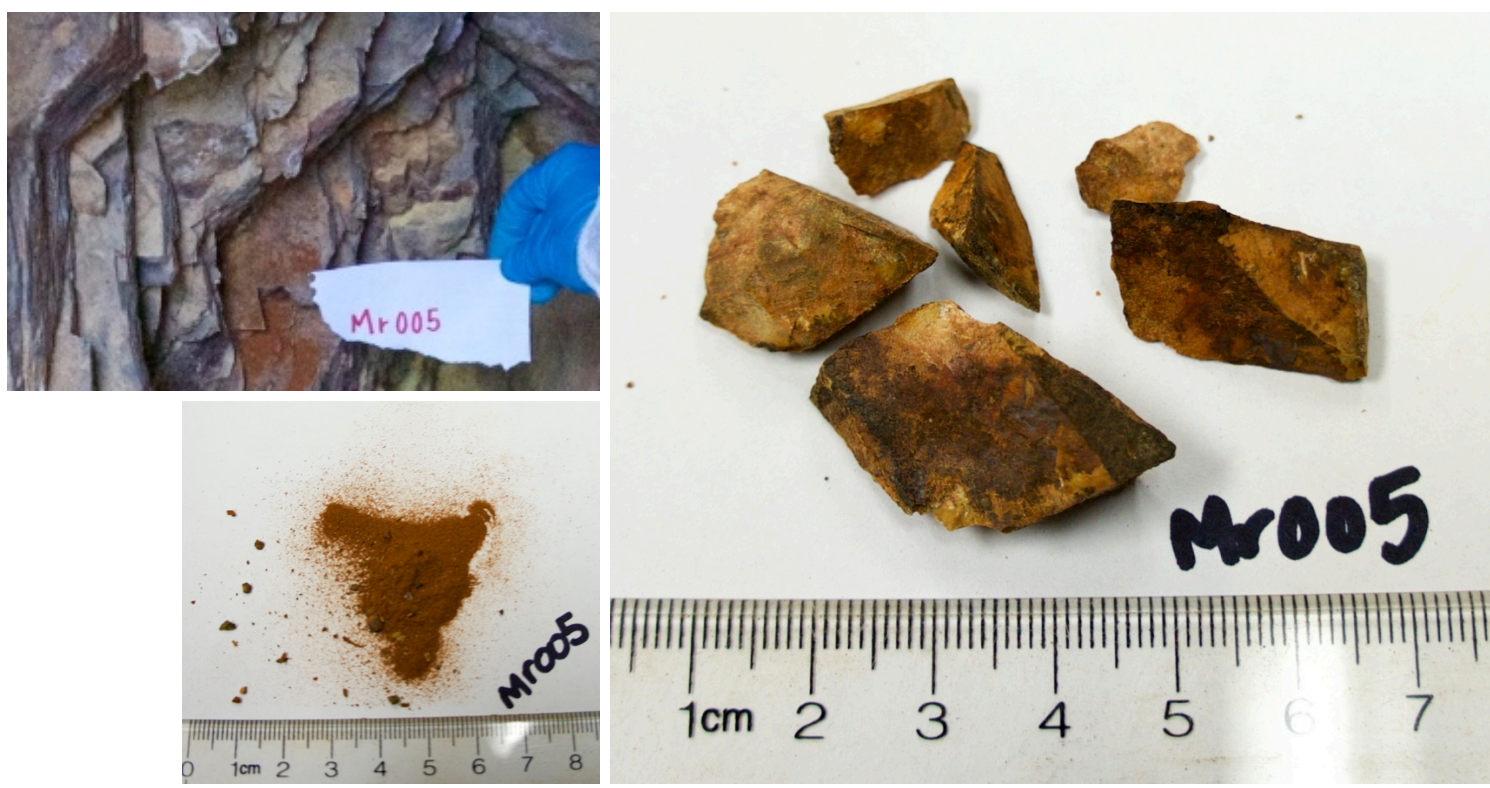

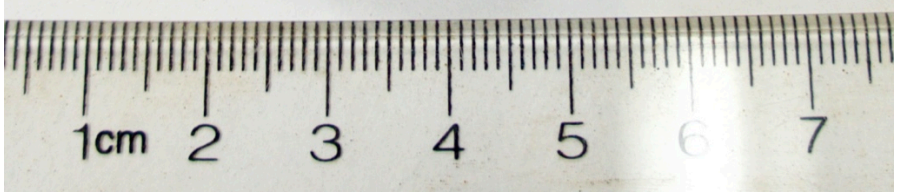



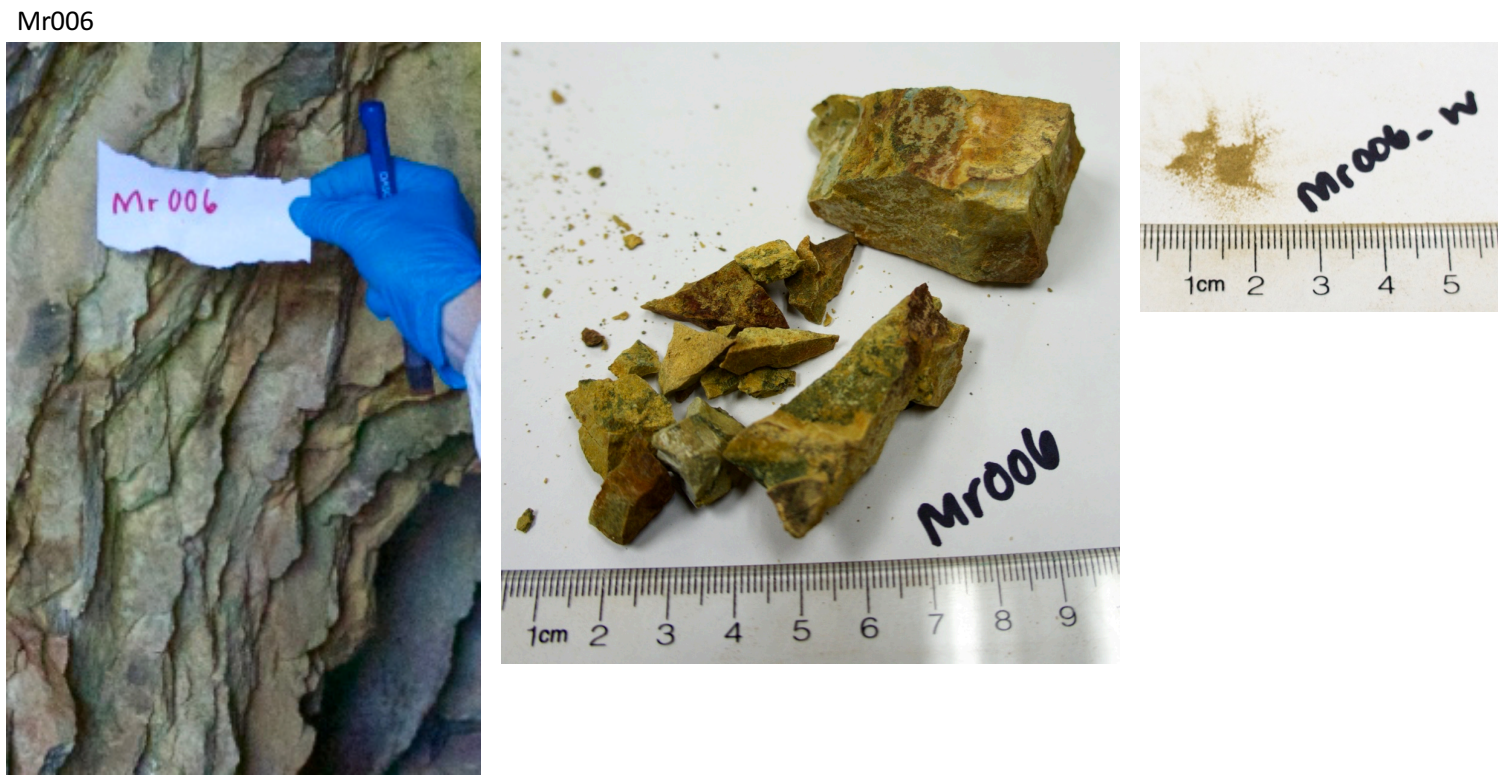

\section{Mk001}
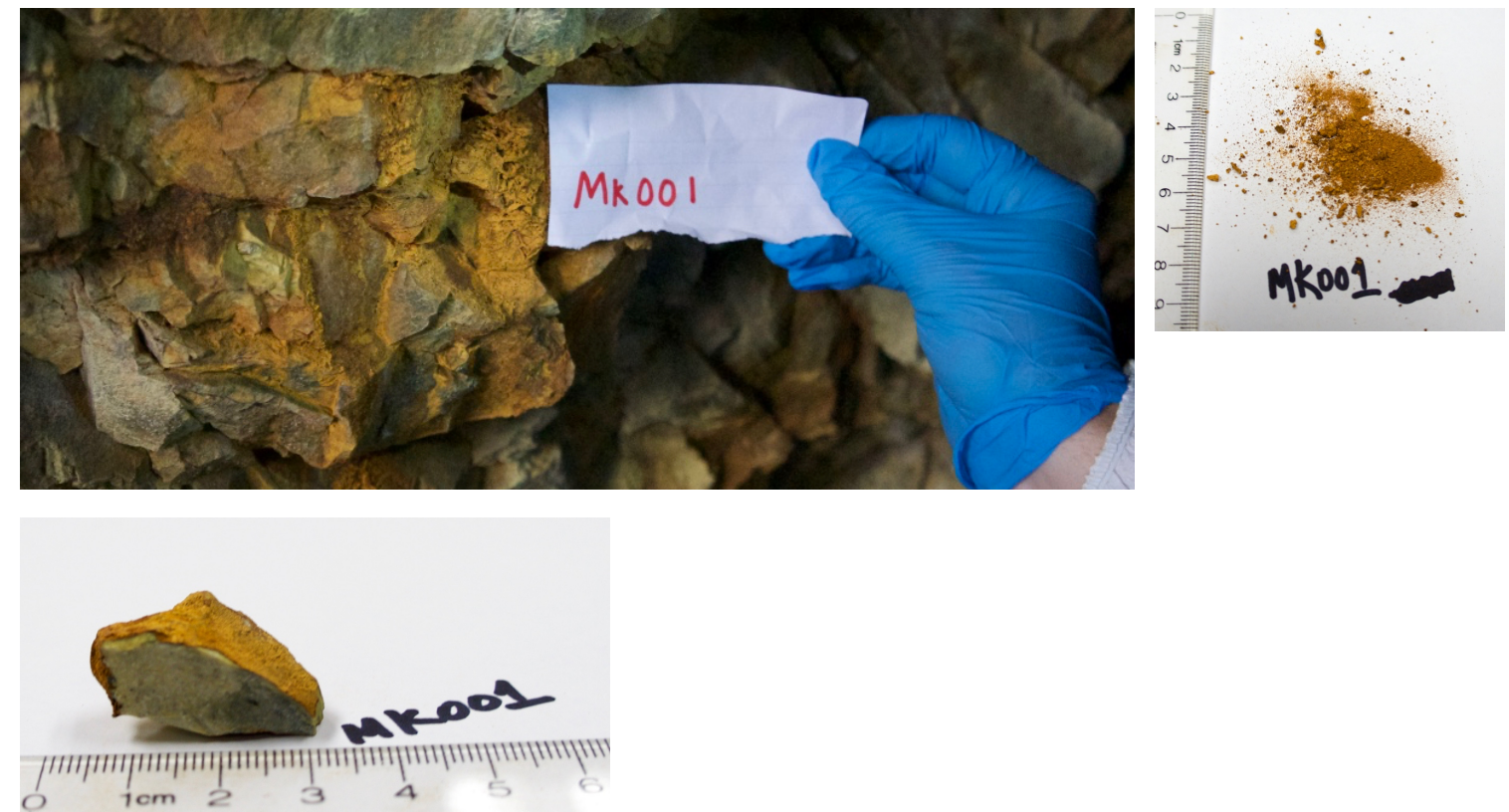

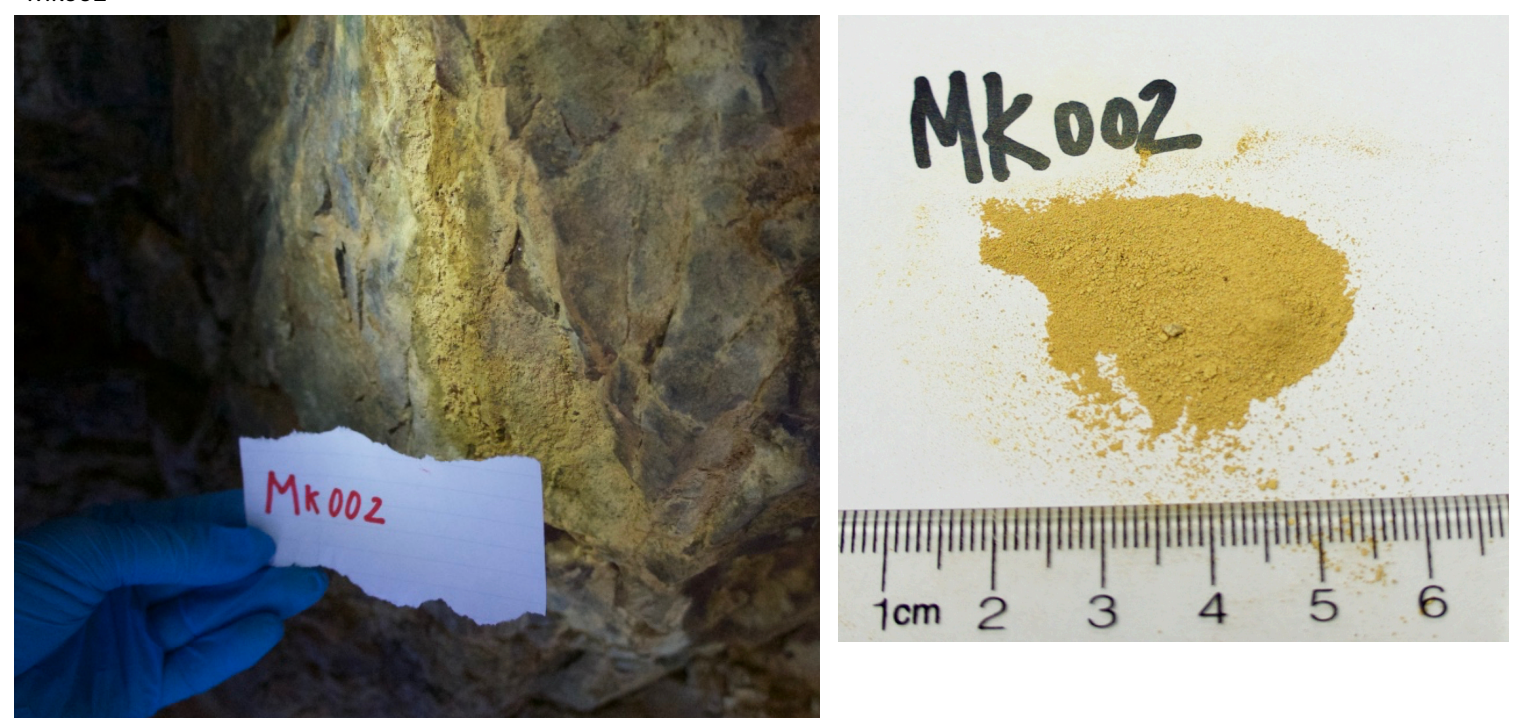

\section{Mk003}
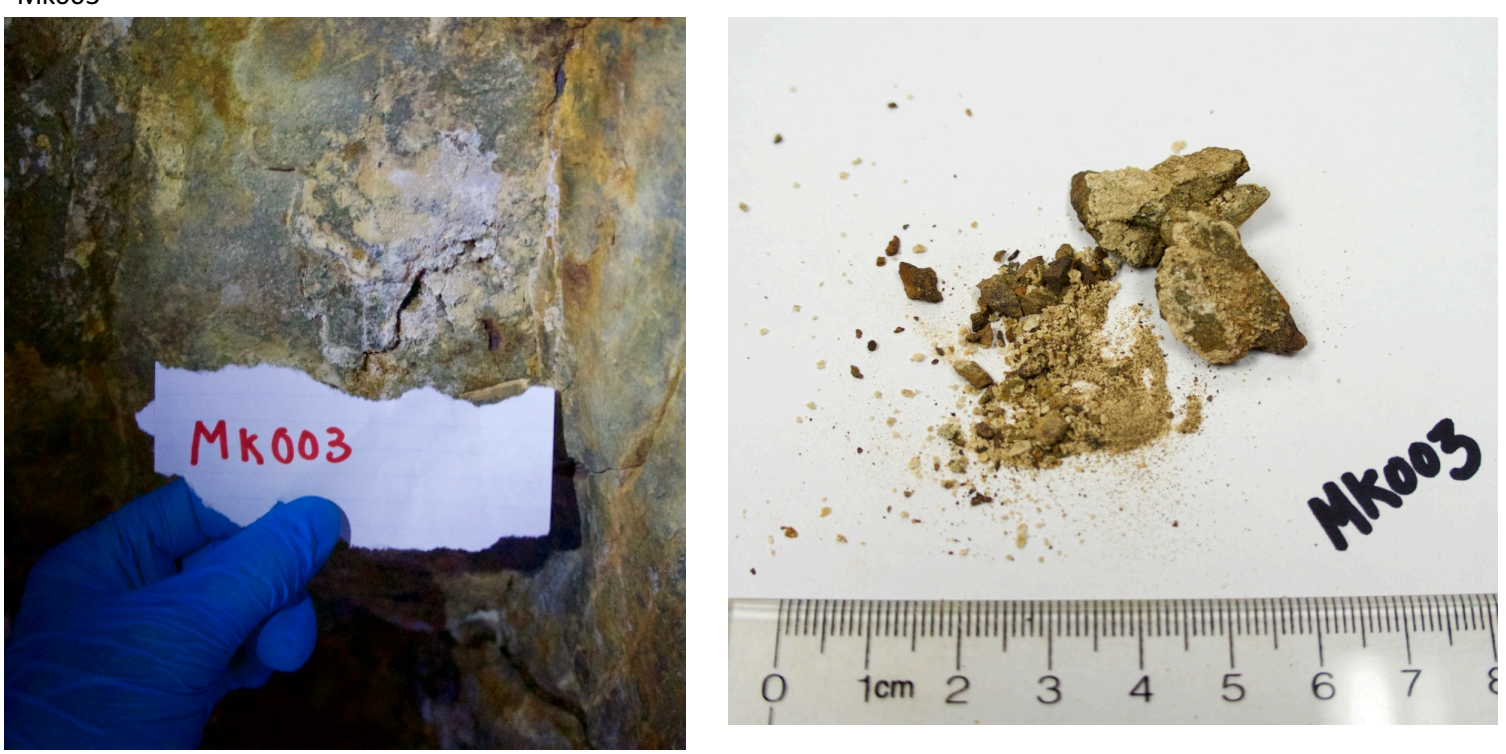

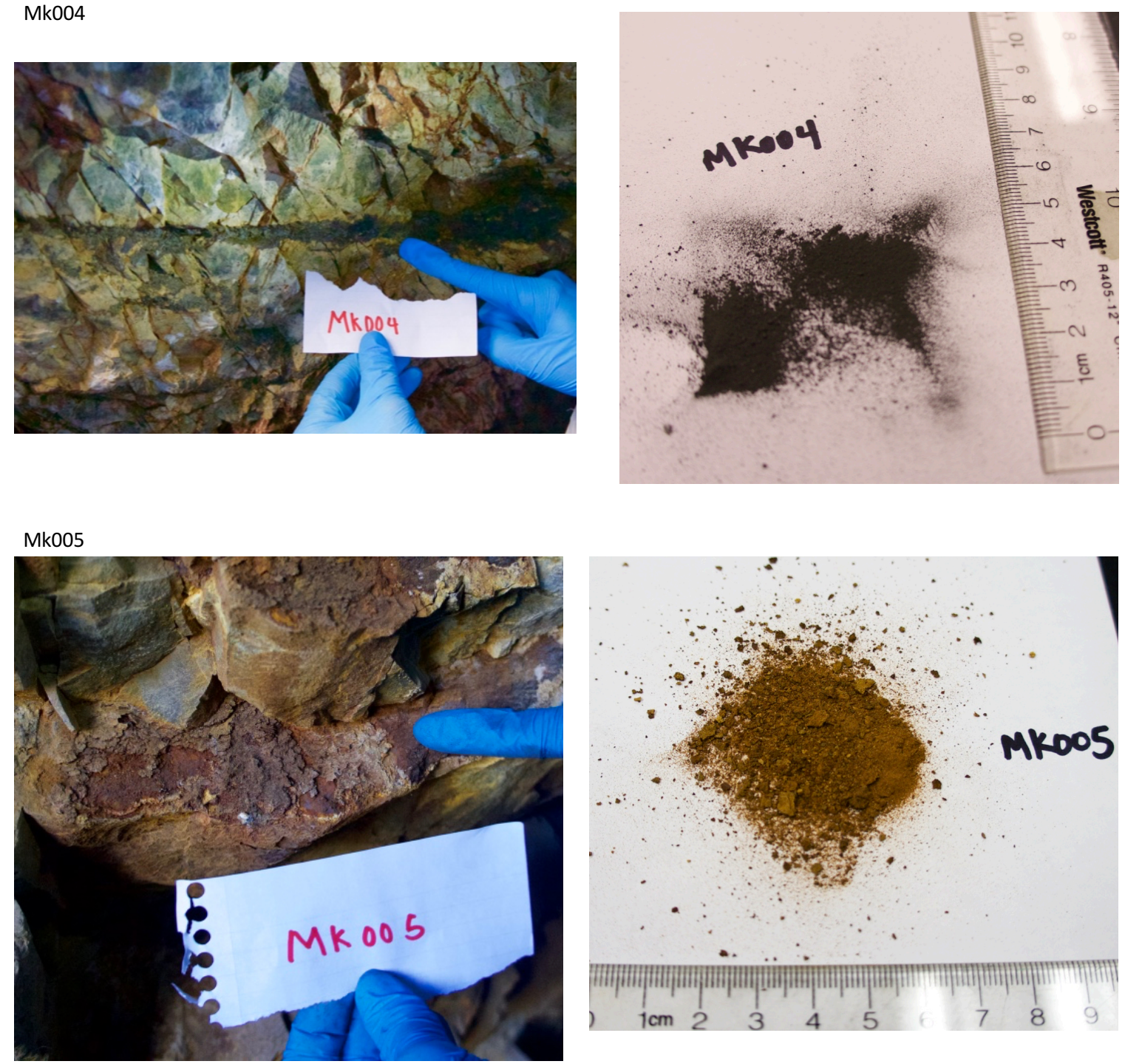

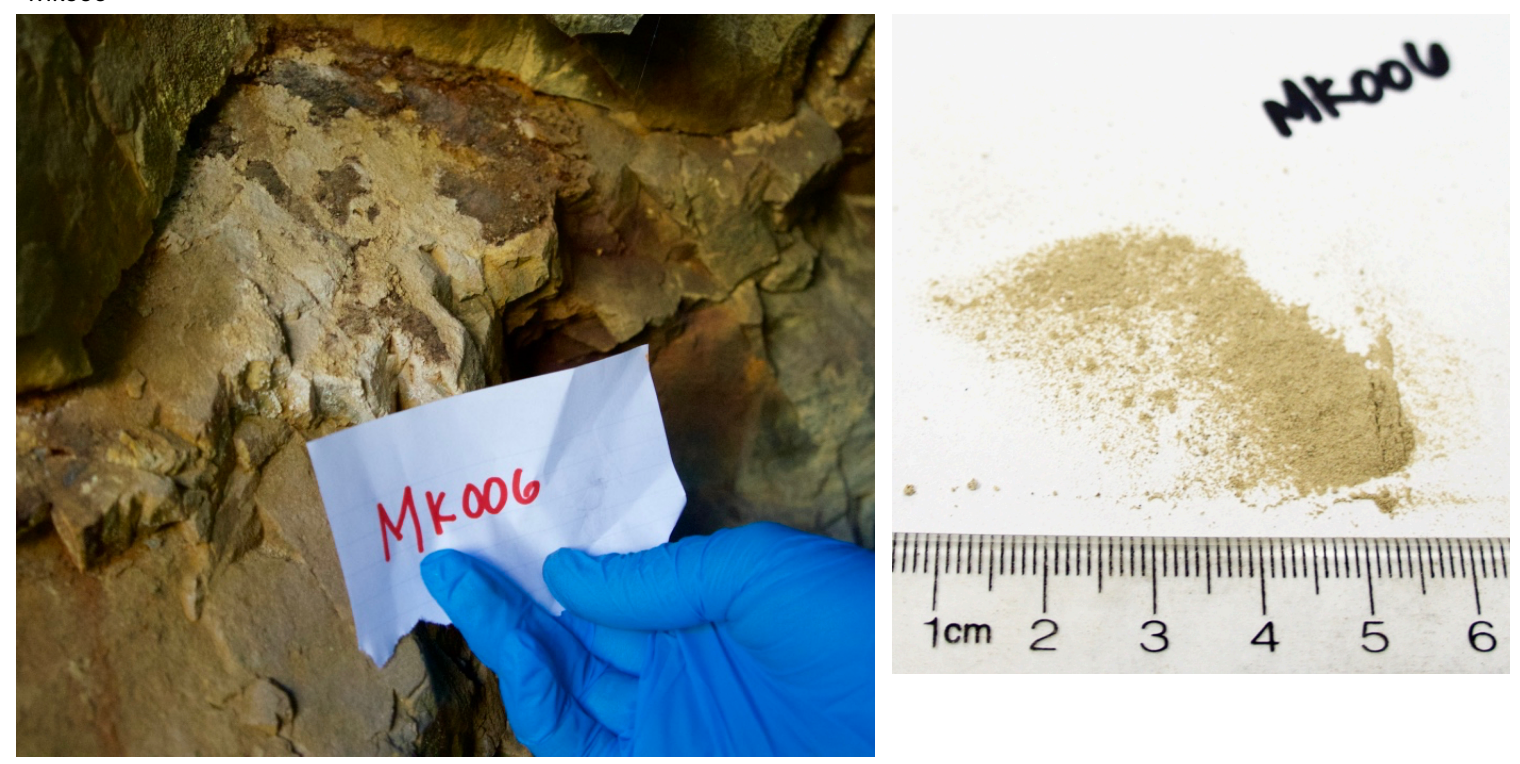
Client Name: University of San Diego

Project Name: Black Mountain Arsenic Verification

EMA Log \#: 16 G0820

ANALYTICAL REPORT FOR SAMPLES

\begin{tabular}{|c|c|c|c|c|}
\hline Sample ID & Laboratory ID & Matrix & Date Sampled & Date Received \\
\hline R022i $>$ Microns & $16 \mathrm{G} 0820-01$ & Solid & $12 / 15 / 1512: 00$ & $07 / 26 / 16 \quad 15: 05$ \\
\hline Mr002 & 16G0820-02 & Solid & $12 / 15 / 1512: 00$ & $07 / 26 / 1615: 05$ \\
\hline Mk004 & 16G0820-03 & Solid & $12 / 15 / 1512: 00$ & $07 / 26 / 16 \quad 15: 05$ \\
\hline
\end{tabular}

The results in this report apply to the samples analyzed in accordance with the chain of custody document. This analytical report must be reproduced in its entirety.

$$
\text { EnviroMatrix Analytical, Inc. }
$$

Page 2 of 5 
Client Name: University of San Diego

Project Name: Black Mountain Arsenic Verification

EMA Log \#: 16 G0820

Total Metals by EPA 6000/7000 Series Methods

\begin{tabular}{|c|c|c|c|c|c|c|c|c|c|c|}
\hline Analyte & & Result & $\begin{array}{c}\text { Reporting } \\
\text { Limit }\end{array}$ & Units & Dilution & Batch & Prepared & Analyzed & Method & Notes \\
\hline \multicolumn{11}{|c|}{ R022i >Microns (16G0820-01) Solid Sampled: 12/15/15 12:00 Received: 07/26/16 15:05 } \\
\hline \multicolumn{2}{|l|}{ Arsenic } & 158000 & 100 & $\mathrm{mg} / \mathrm{kg}$ & 100 & 6073002 & $07 / 30 / 16$ & $07 / 31 / 16$ & EPA 6010 & HT-04 \\
\hline \multicolumn{11}{|c|}{ Mr002 (16G0820-02) Solid Sampled: 12/15/15 12:00 Received: 07/26/16 15:05 } \\
\hline \multicolumn{2}{|l|}{ Arsenic } & 165000 & 100 & $\mathrm{mg} / \mathrm{kg}$ & 100 & 6073002 & $07 / 30 / 16$ & $07 / 31 / 16$ & EPA 6010 & HT-04 \\
\hline \multicolumn{11}{|c|}{ Mk004 (16G0820-03) Solid Sampled: $12 / 15 / 15$ 12:00 } \\
\hline Arsenic & & 390000 & 100 & $\mathrm{mg} / \mathrm{kg}$ & 100 & 6073002 & $07 / 30 / 16$ & $07 / 31 / 16$ & EPA 6010 & HT-04 \\
\hline
\end{tabular}

The results in this report apply to the samples analyzed in accordance with the chain of custody document. This analytical report must be reproduced in its entirety.

EnviroMatrix Analytical, Inc.

Page 3 of 5 
Client Name: University of San Diego

Project Name: Black Mountain Arsenic Verification

EMA Log \#: 16G0820

Total Metals by EPA 6000/7000 Series Methods - Quality Control

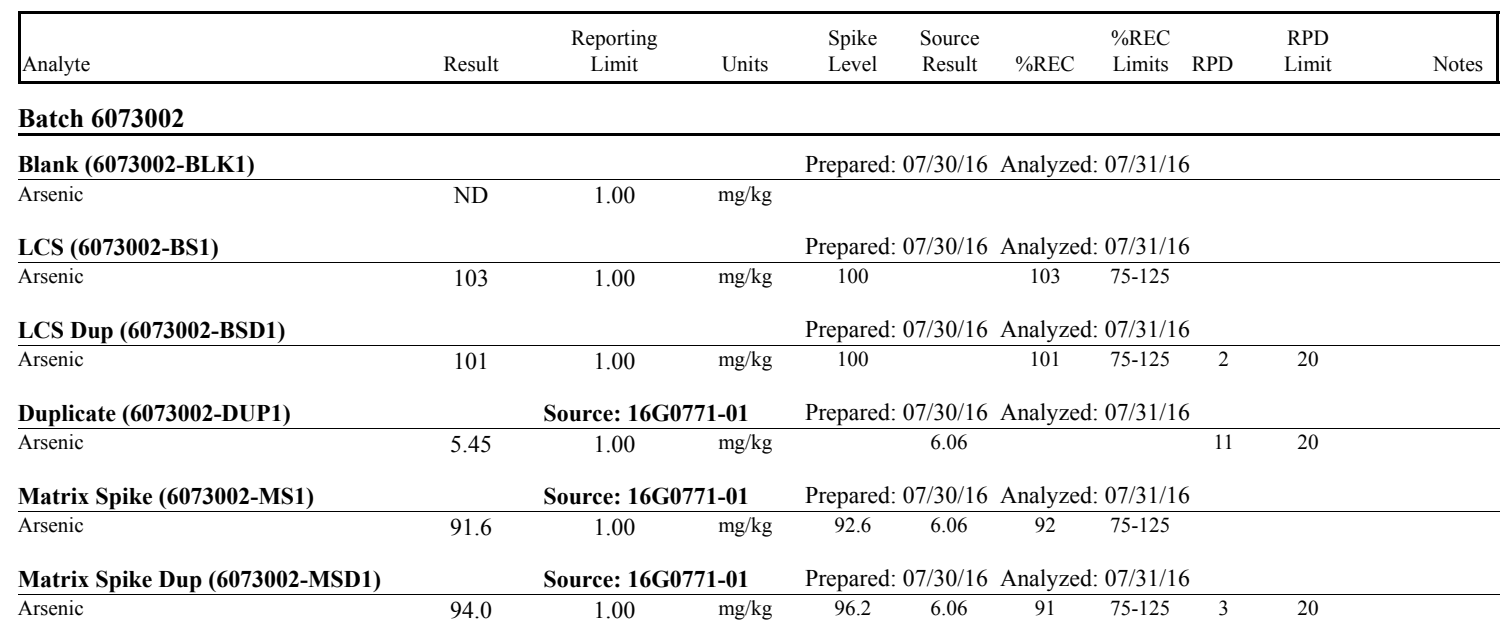

The results in this report apply to the samples analyzed in accordance with the chain of custody document. This analytical report must be reproduced in its entirety.

EnviroMatrix Analytical, Inc.

Page 4 of 5 
Client Name: University of San Diego

EMA Log \#: 16G0820

Project Name: Black Mountain Arsenic Verification

\section{Notes and Definitions}

HT-04 This sample was received outside of the EPA recommended holding time for this analysis.

ND Analyte NOT DETECTED at or above the reporting limit

NR Not Reported

dry Sample results reported on a dry weight basis

RPD Relative Percent Difference

The results in this report apply to the samples analyzed in accordance with the chain of custody document. This analytical report must be reproduced in its entirety.

EnviroMatrix Analytical, Inc.

Page 5 of 5 


\section{APPENDIX I: Scanning Electron Microscope (SEM)}

\section{Methods}

A representative subset of whole rock samples $(n=7)$ were cut into billets for analysis by Scanning Electron Microscope (SEM) at the University of San Diego. Billets were first polished using 600,800 , and 1,200 grit polishing papers and gold coated for 30 seconds with a sputter coater. Energy dispersive spectrometry (EDS) at $15 \mathrm{keV}$ was then used to preform surface imaging using backscattered electron (BSE) techniques, and elemental mapping was conducted using wavelength dispersive spectroscopy (WDS).

\section{Results}
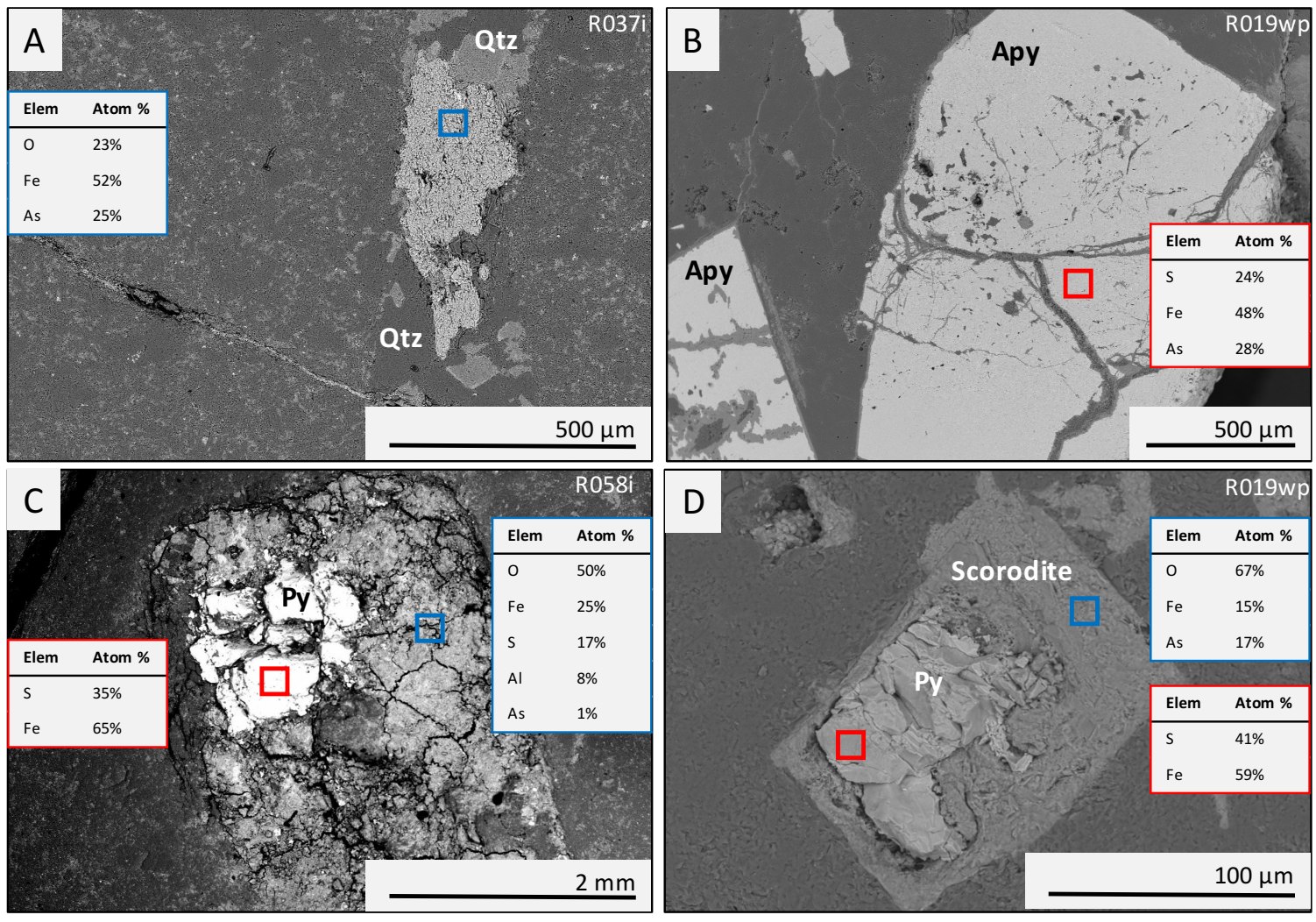

Fig 1: BSE images of a) scorodite-bearing quartz vein in an altered rhyolite (R037i), b) 1 mm arsenopyrite crystals in rock disturbed by mining (R019wp), c) highly weathered pyrite in an altered dacite (R058i), d) pyrite with scorodite halo in rock disturbed by mining (R019wp). Blue and red squares represent areas of the sample that were point analyzed by WDS, and resulting atomic percentages are given in tables of corresponding color. 

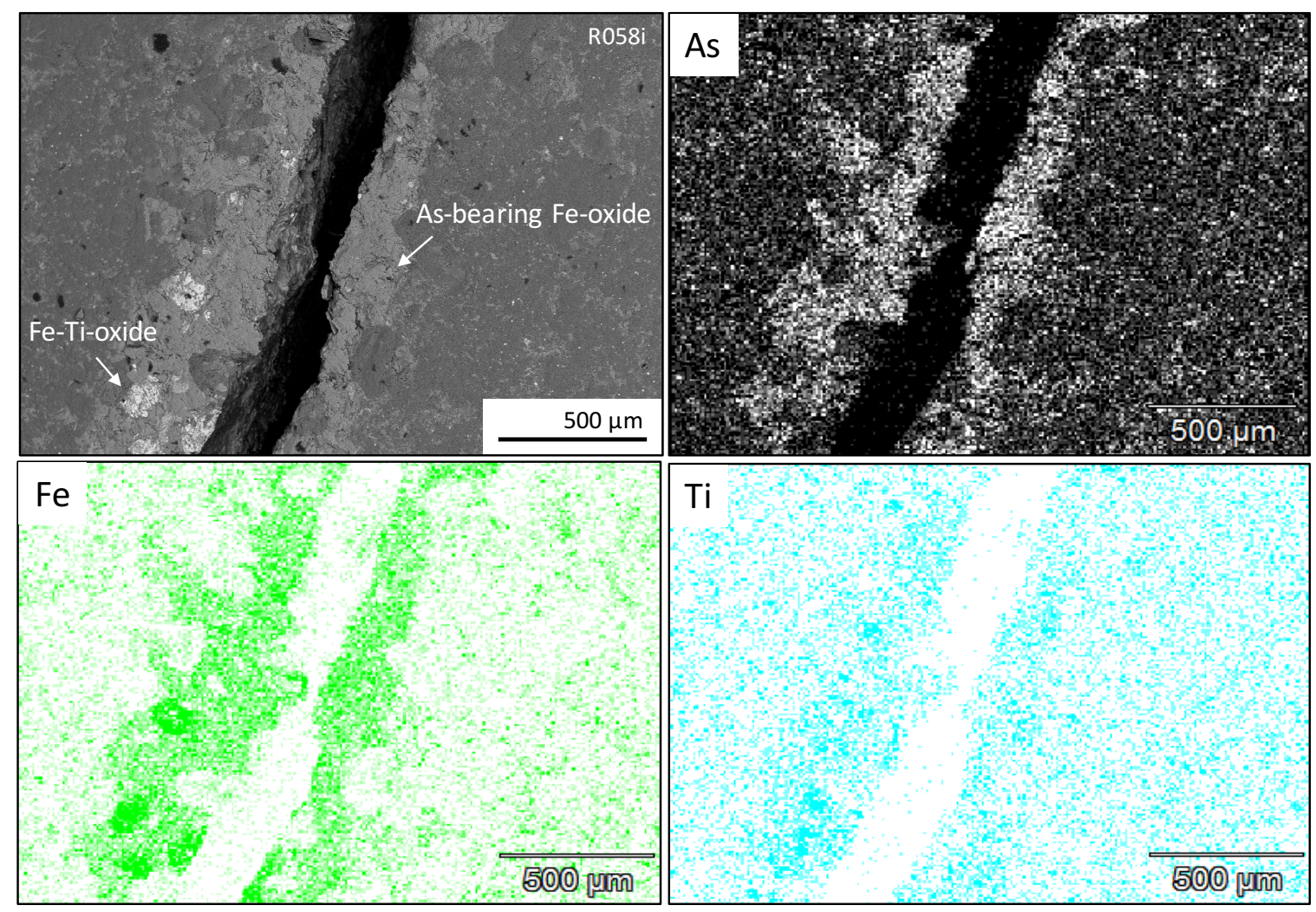

Fig 2: SEM image and elemental mapping indicate presence of As-bearing iron oxides along fractures of an altered dacite (R058i). 